\title{
إطلالة على الجنسية في الفقه \\ الإسلامي والقانون الدولي الخاص
}

\author{
دكثور \\ عبد اللّه عبد الحميل سبيد أحمد دكيول
}

دكتوراه القانوز الدولي الخاص

كلية الحقوق - جامعة عين شمس 



\section{unil|}

سوف نتتاول في هذا البحث بياناً لتعريف الجنسية في الفقـــه الإســلامي و القانون الدولي الخاص ونظرة كلاً من الجانبين للجنسية، وبيان وجهات النظر

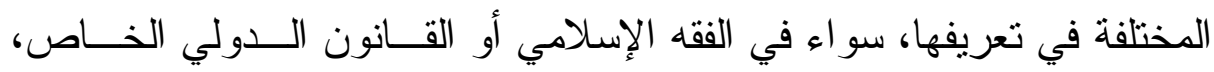
وسوف نتطرق لبيان مفهوم المو اطنة في الفقه الإســلامي و القــانون الــدولي الخاص بحسبان أننا نعيش في عصر بعلي من شـــأن المو اطنــة أي الانتمـــاء للوطن و الارنباط به بناء على مفهوم الجنسية كر ابطة قانونية بين الفرد و الدولة بصرف النظر عن العقيدة إعمالاً لما ورد في الدستور المصري من تكــريس مبدأ حرية العقيدة و احتر ام مبدأ المساو اة بين جميع المصريين وعــدم التمييـز ورئز بينهم بسبب الجنس أو العقيدة.

كذلك سوف نوضح اتجاهات الفقهاء في الفقه الإسلامي ما بــين إنكــار و اعتر اف بوجود الجنسية من عدمه استتاداً لـنص القــر آن و الســـنة النبويـــة

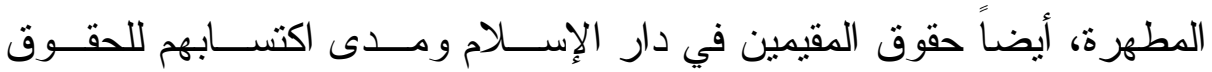
و تكليفهم بالو اجبات، فالثريعة الإسلامية لم تتكر حقوق غير المسلمين بل على إلى العكس تماماً أوجبت احتر ام حقوقهم و إعطاءها لهم و عدم الانتقاص منها، كذلك عدم التعرض لهم بالأذى سواءً بالقول أو الفعل ، فالثريعة الإسلامية قد سبقت

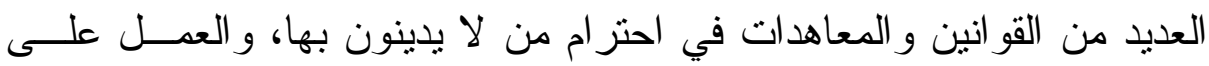
تز كهم وما بدينون.

وقد استقى القانون الدولي الخاص العديد من مبادئه من نبــع الثــريعة

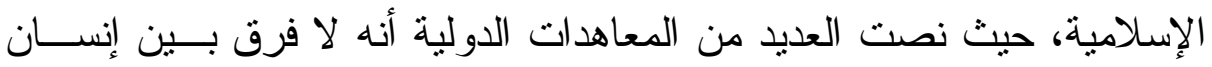
و آخر و لا يجوز التمبيز و التفرقة بين البشر وبعضهم علــى أســاس الــدين أو

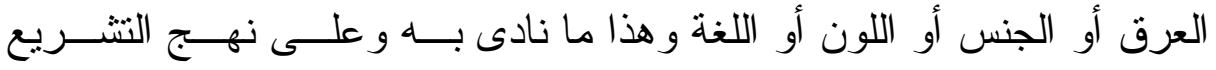
الإسلامي الإعلان العالمي لحقوق الإنسان، ومن جانبنا نميل إلى الدمج بين ما

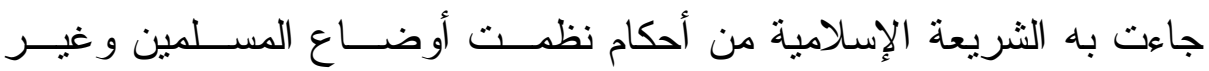

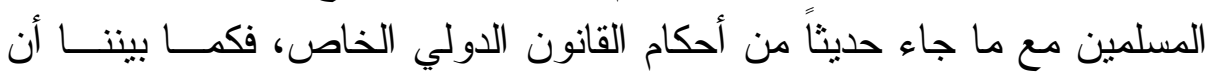
الأخير قد استقى العديد من أحكامه من رحاب الأولى، وهو ما يؤكـــد النظـــرة المستقبلية التي حبى بها الله الثريعة الإسلامية. 
العلد الثاني- الجزء الأول- السنة التاسعة والخمسون-يوليو Vا.r

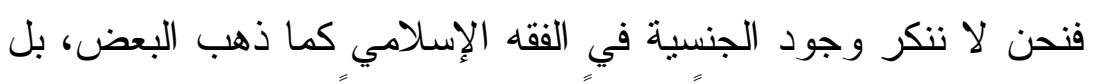

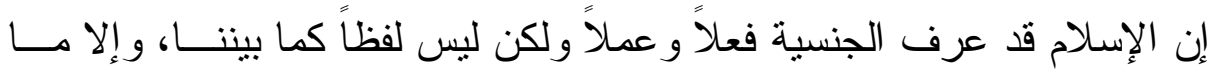

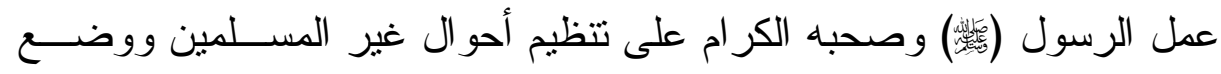
الضو ابط التي تضمن عدم تعرضهم للمتاعب أو المضايقات.

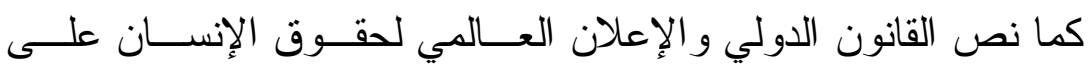

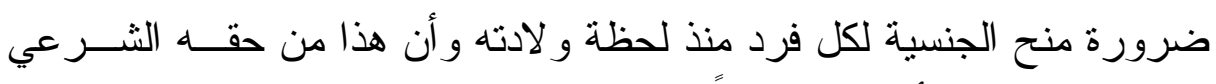
و لا يجوز حرمان أحد منه تعسفاً. 


\section{|القدمهة}

عرفت فكرة الجنسية منذ القدم وتطورت بتطور الحيــاة الاجتماعيـة،

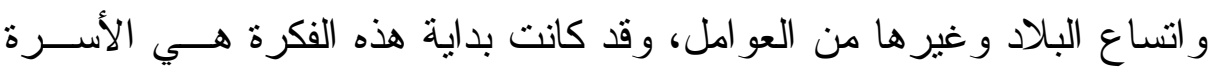

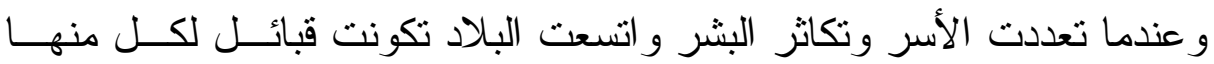

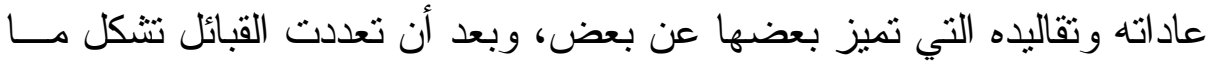

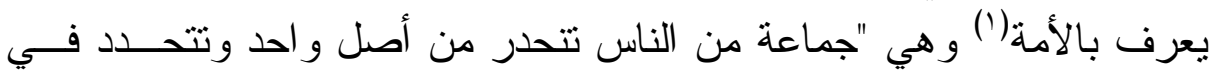

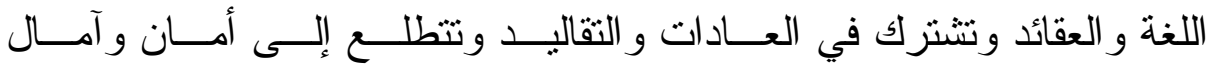

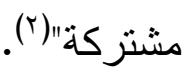

و ارتبطت فكرة الجنسية بالأسرة و القبيلة و الأمة فكانت تعبر عن انتماء

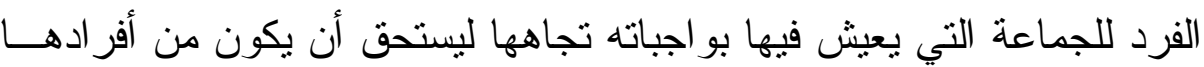

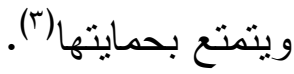

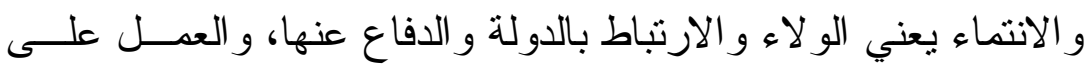

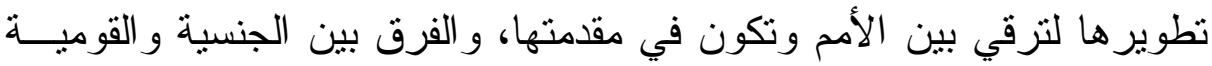

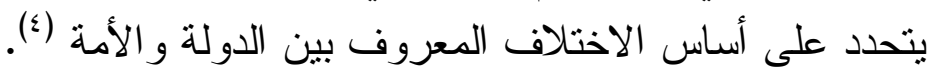

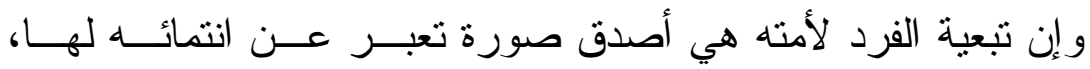

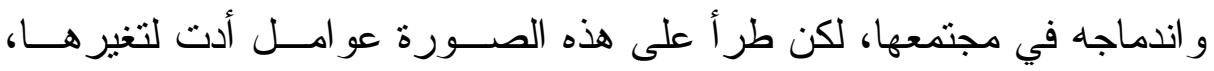

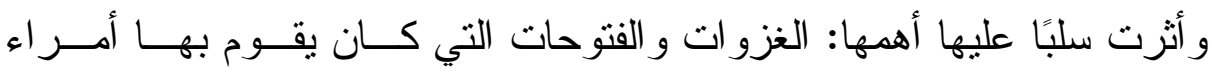

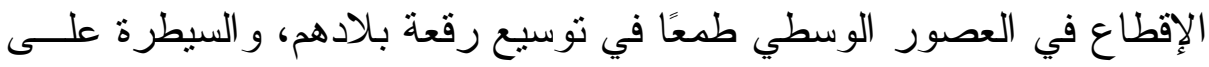

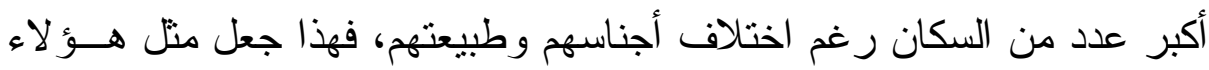

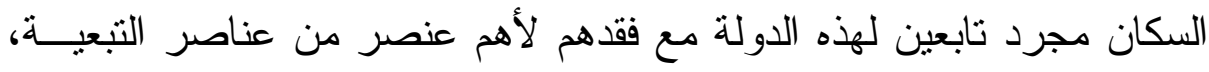

د. عز الدين عبد الله: القانون الدولي الخاص المصري في الجنسية والموطن وتمتع

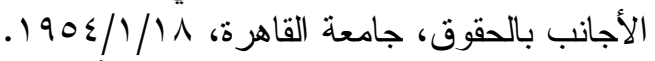

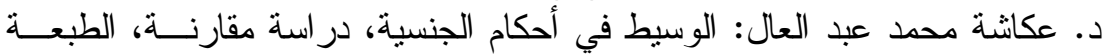

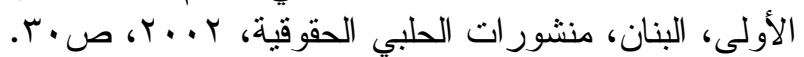

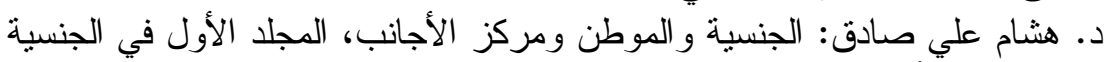

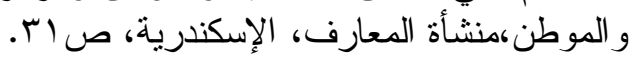

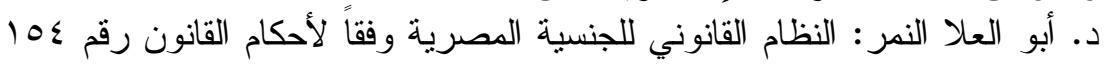

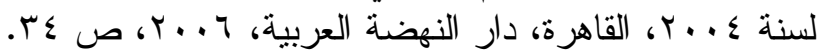


و هو الو لاء و الإخلاص للدولة التي ينتمون إليها، حيث أصبحت الجنسية مجرد رابطة يخضع بها الفرد لسيطرة الحاكم (').

- - و القانون في أي مجتمع من المجتمعات تعبير عـن مفـــاهيم و أفكــار

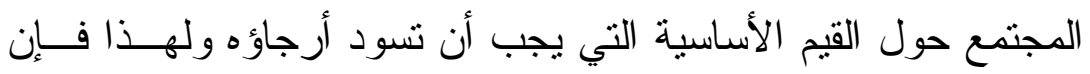
أحكامه تزجمة لما يعيشه وما يعتتقه من أفكار .

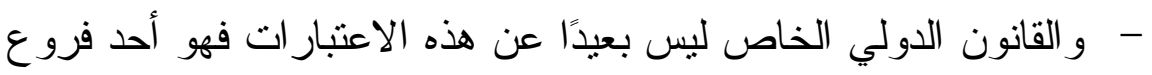

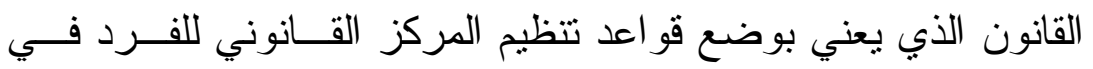
مجال العلاقات الخاصة الدولية أو العلاقات ذات العنيم العنصر العز الأجنب.

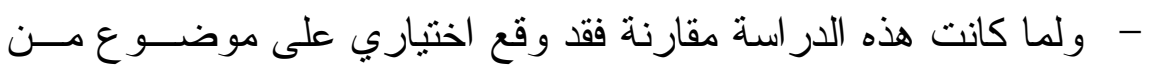

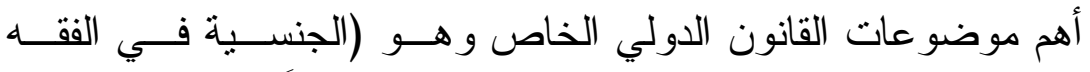

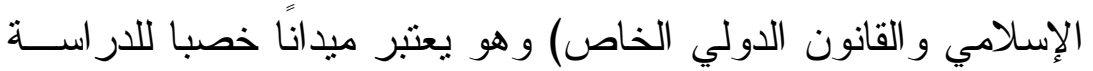
و المقارنة قديمًا وحديثًا.

\section{ويرجع اختباري له للعدبِ من الأسباب من أهمها ما بلي:-}

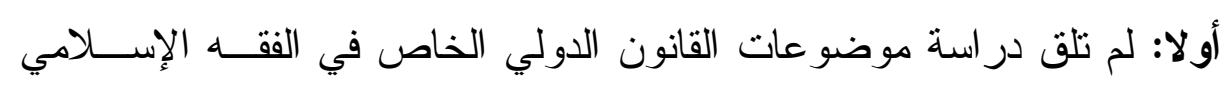

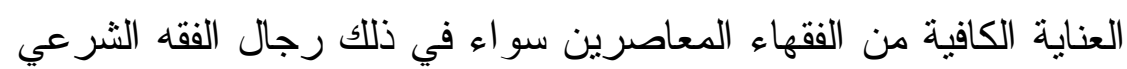

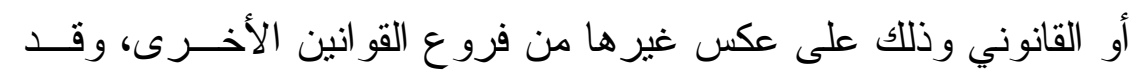

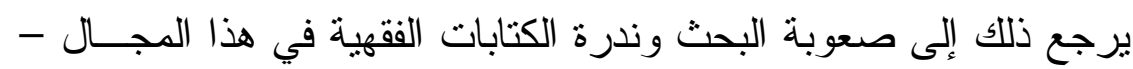

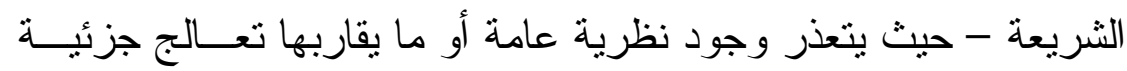

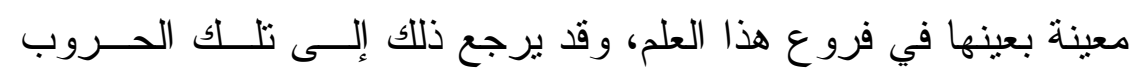

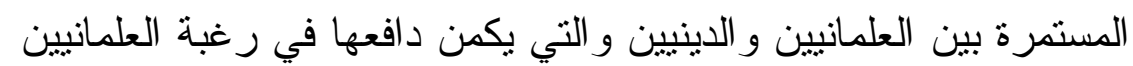
الحد من تدخل الدين في الحياة اليومية للأفر اد.

الأمر الذي دفع البعض إلى إهمال البحث في منل هذا الموضوع تجنبً

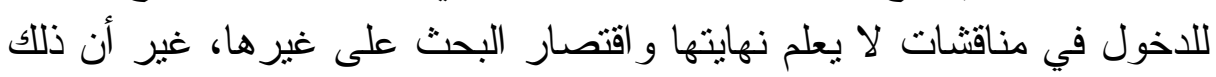

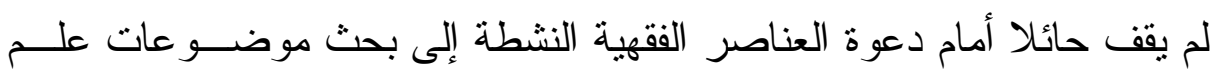

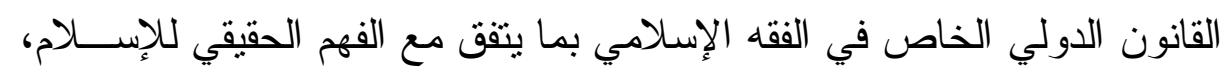

طلعت محمد دويدار : القانون الدولي الخاص السعودي، الإسكندرية منشأة المعارف،

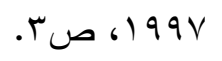


فهو حقيقته دين ودولة، عقيدة وشريعة يشمل جميع نواحي الحيــاة وينتو لاهـــا بالتنظيم.

ثانيًا: تعتبر مسألة الجنسية من الموضوعات الهامة و التي أولتهـــا الاتفاقيــات

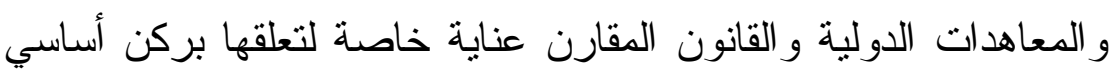
لازم لقيام الدولة وهو ركن الثعب، ومن أهم خصائصه الدوام و التجدد. ثالثًا: من الأمور المسلمة أن العلاقات و الرو ابط الاجتماعية عمومًا و الأســرية

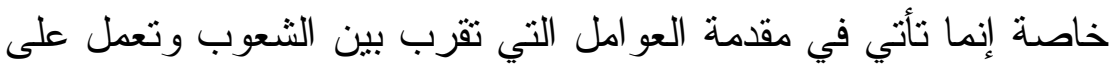

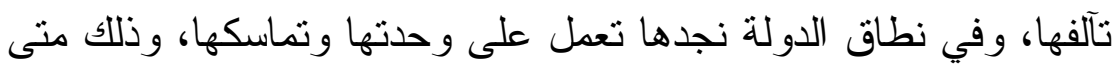

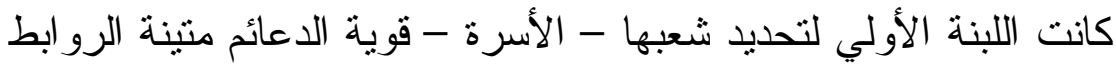
منوحدة في الأهداف و المشارب.

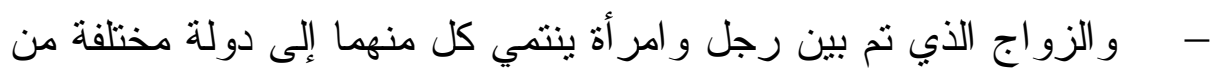

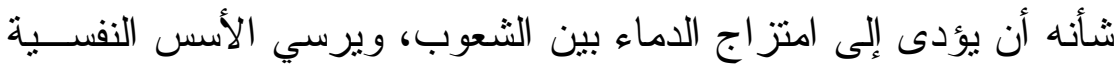

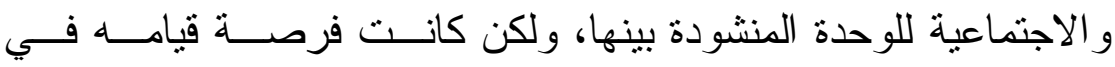

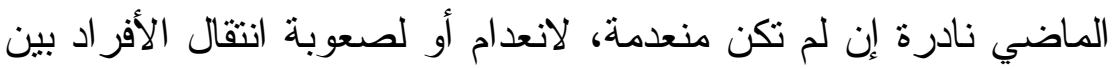

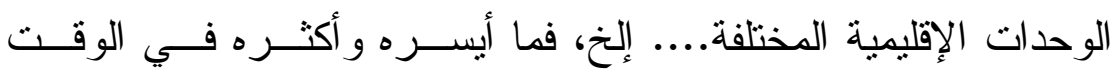

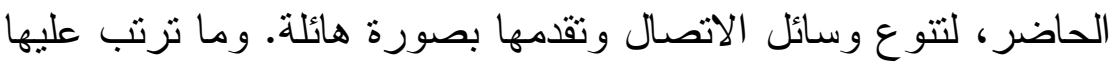

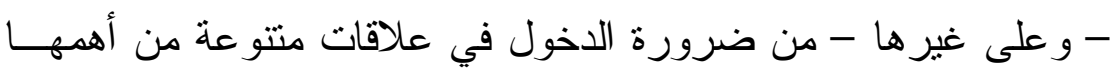

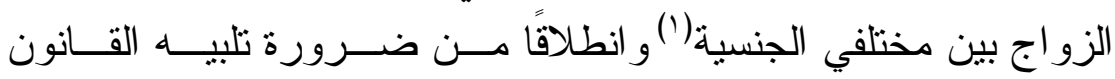

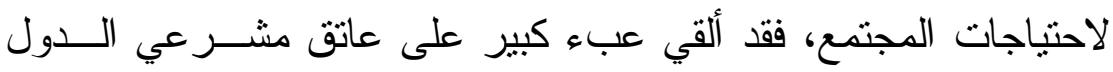

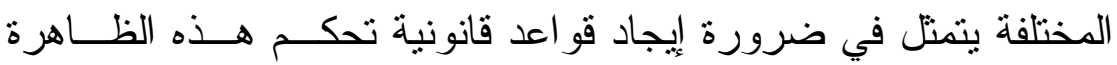
المتز ايدة على مستوي أطر افها، بما يكفل لنعبها الاستقر ار و الأمان. - - ولقد سبق الفقه الإسـامي تلك التشريعات الحديثة ببيانه للأحكام المتعلقــة

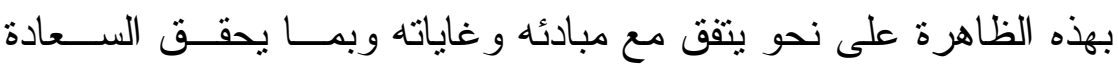

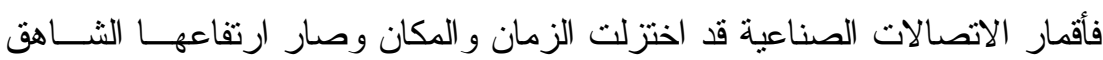

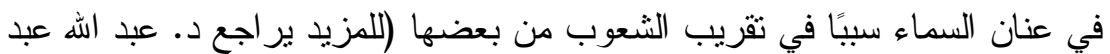

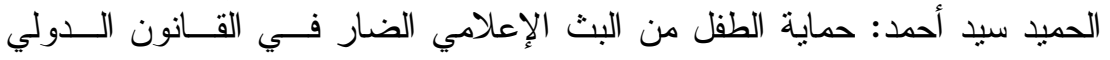

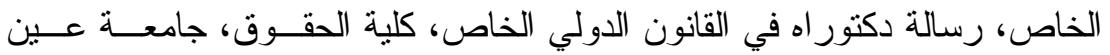

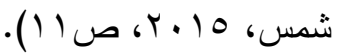


لأتباعه في الانيا و الآخرة، ولغيرهم الاستقر ار و الاطمئنان و العيش فـي أمان... الخ.

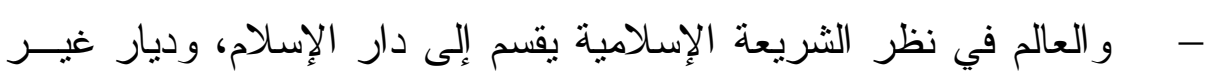

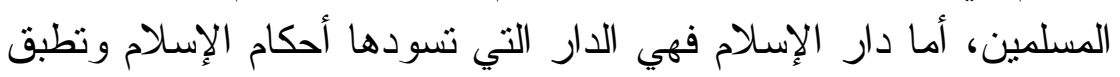

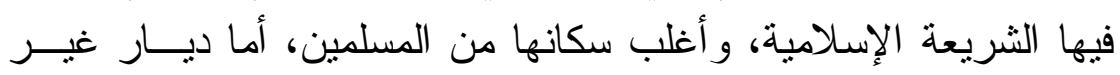

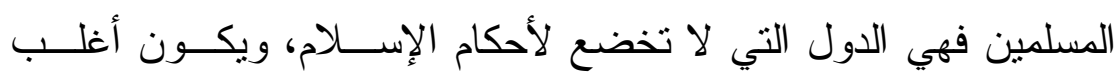

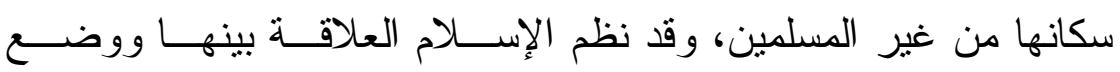

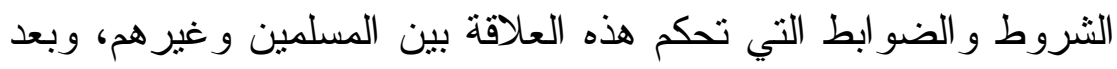

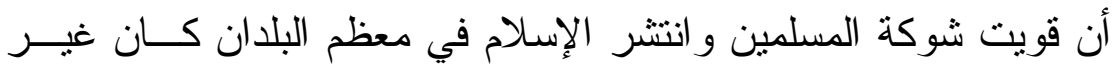

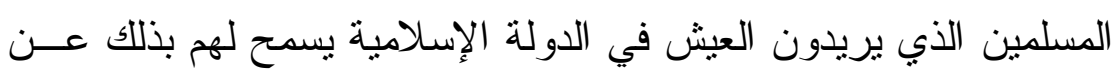

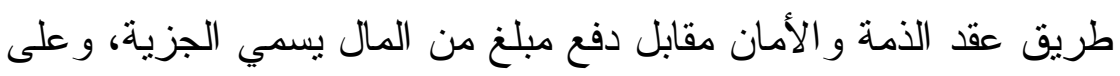

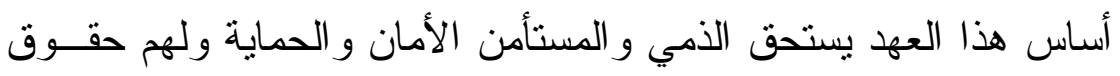
و عليهخ و اجبات كالمسلمين.

وفي الآونة الأخيرة يلاحظ انتقال بعض المسلمين من بلاد المسلمين إلى الى

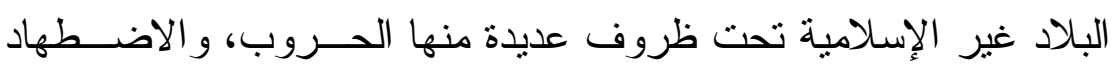

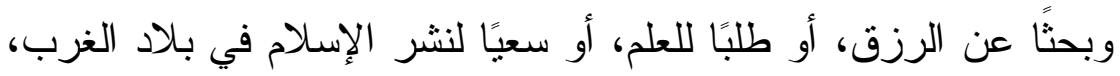

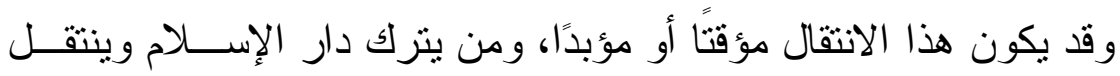

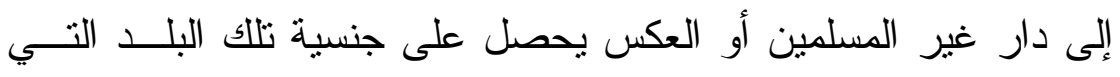
انتقل إليها إن أر اد الإقامة الدائمة فيها ومقابل الحصول على على الجنسية قد يتخلي المتجنس عن جنسيته الأصلية ويخضع لأنظمة وقو انين ذلك البلد.

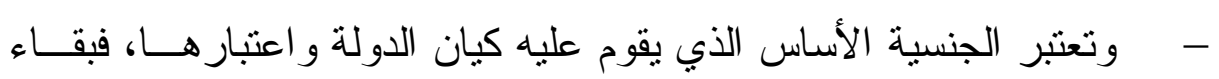

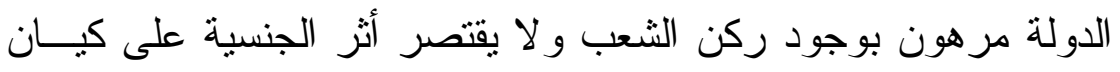

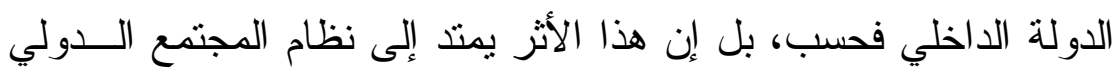

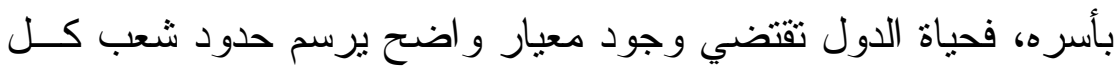

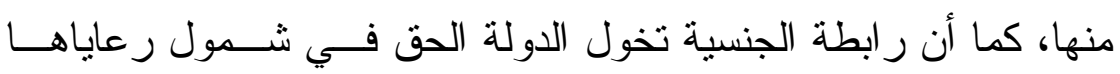

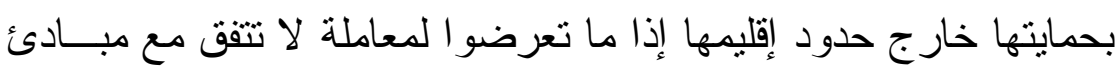

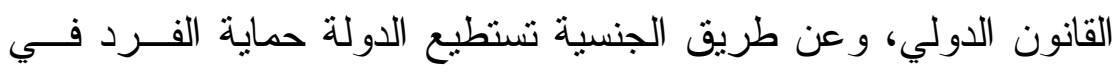
المجتمع الدولي، فالفرد الذي لا يحمل جنسية دولة لا يتمتع بأي حماية. 
هناك أهداف كثيرة من ور اء هذا البحث ومنها:

أنه من خلال در استي للقو انين الوضعية وجدت أن الفقه القـانوني فــي

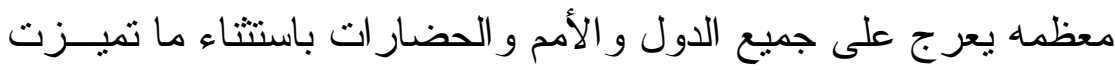

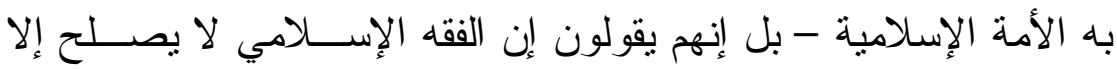

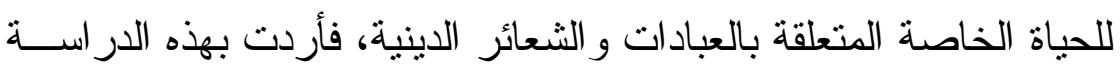

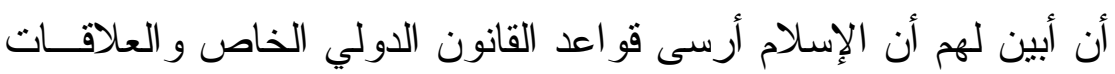
الدولية سيما في مجال الجنسية.

إن الفقهاء المعاصرين تكلمو ا عن الجنسية من وجهة شر عية مختصــرة

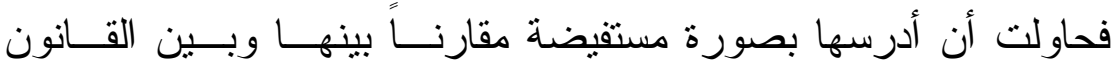
الوضعي (القانون الدولي الخاص).

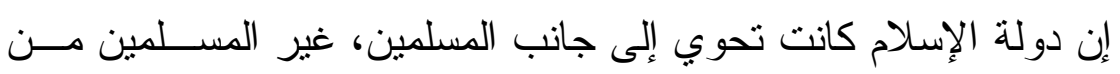

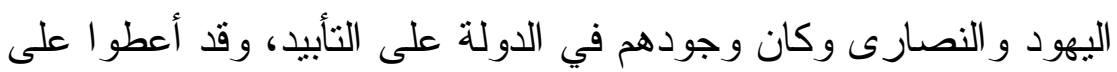

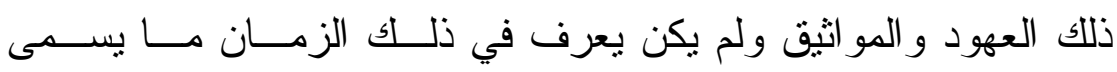

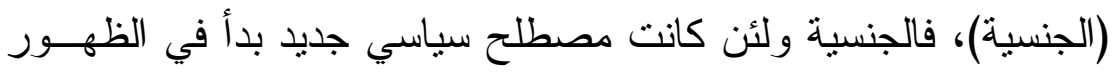
في أواخر القرن الثامن عشر مع ظهور مبدأ القوميات في أوروبـــا، إلاً

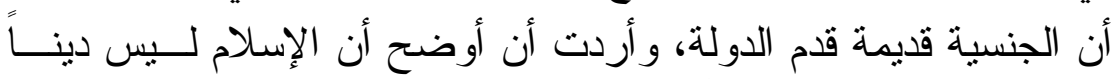

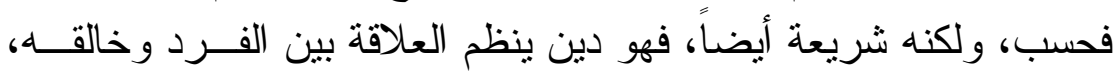

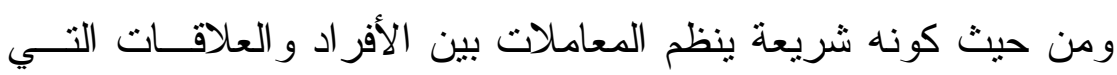

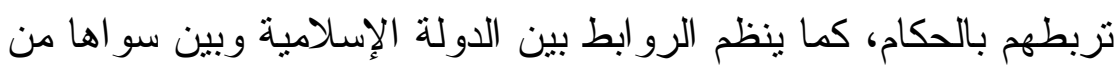

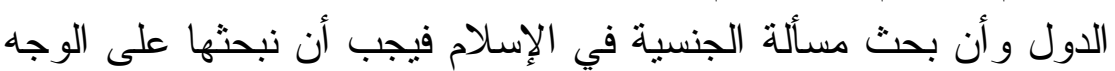

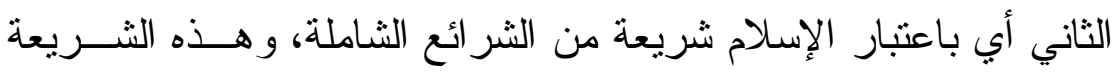

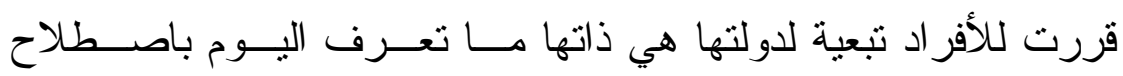

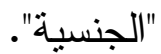
توضيح حقيقة الجنسية و المو اطنة في القانون الدولي و الإعلان العـالمي لحقوق الإنسان. 
العدد الثاني- الجزء الأول- السنة التاسعة والخمسون-يوليو Vا.r

وقد قسمت الار اسة في هذا الموضوع إلىى أربعة مباحث على النحو التالي:المبحث الأول : ماهية الجنسية في الفقه الإسلامي والقاتون الدولي الخاص. المبحث الثاني: آراء فقهاء القانون الدولي الخاص تجاه الجنسية وتقدير هذه الآراء.

المبحث الثالث: نظرة على جواتب الجنسية والمواطنة في الفقــهـه الإســلامي والقانون الاولي الخاص. المبحث الرابع: تقدير الفقه الإسلامي للجنسية. الخاتمة. 
العدد الثاني- الجزء الأول- السنة التاسعة والخمسون-يوليو V|r r

\section{المبمث الأول}

ماهية الجنسية في الفقه الإسلامي والقانون الدولي الخاص

تمهيد:

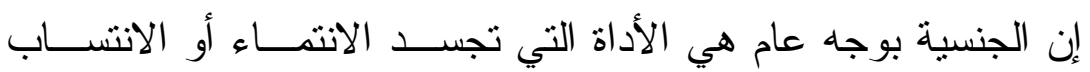

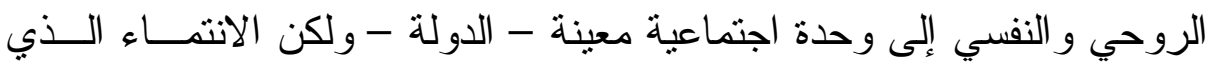

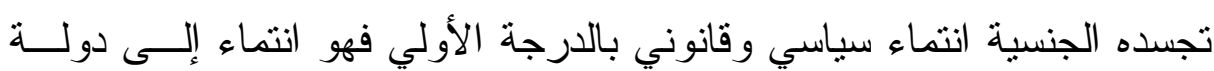

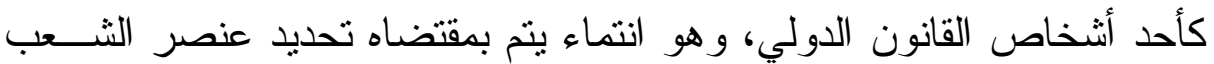

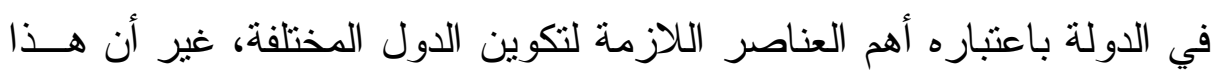
الانتماء السياسي و القانوني لم يظهر طفرة واحدة الاعن، بل أخذ يتطور بتطور الفكر

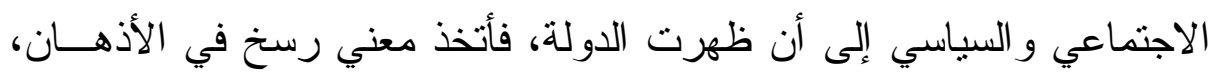
وتو اتز عليه الفكر القانوني.

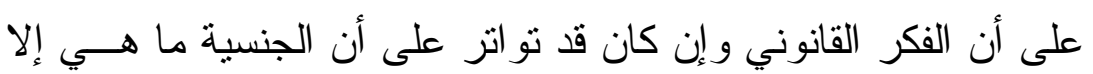

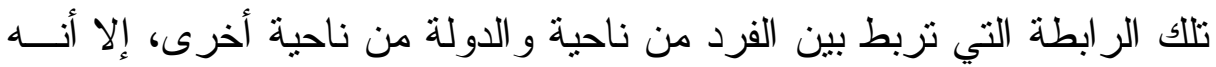

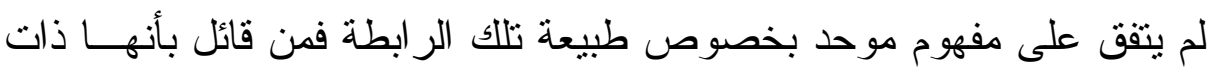

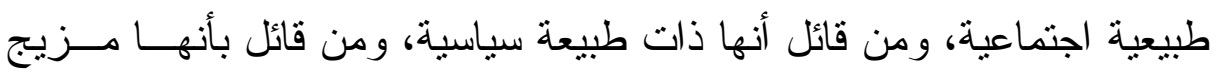

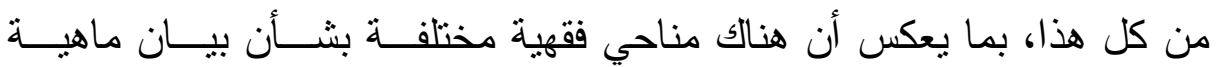

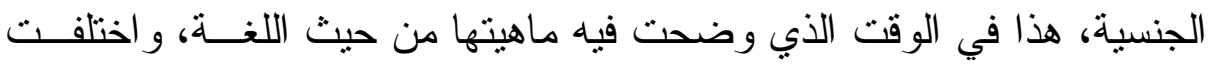

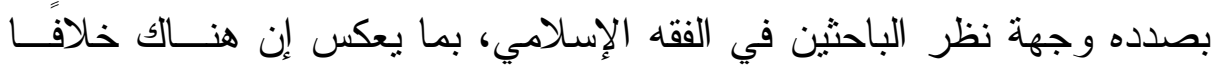
بشأن وجودها في الفقه الإسلامي. لألك نقترح معالجة تلك الأمور تباعًا ويالتفصيل على النحو التالي: المطلب الأول : ماهية الجنسية في اللغة. المطلب الثاني: ماهية الجنسية في الفقه الإسلامي. المطلب الثالث: ماهية الجنسية لاى فقهاء القانون الدولي الخاص. 


\section{الإطب الأول \\ ماهية الجنسية في اللافة}

نتعرض في هذه الجزئية لبيان ماهية الجنسية في كل من اللغة العربية

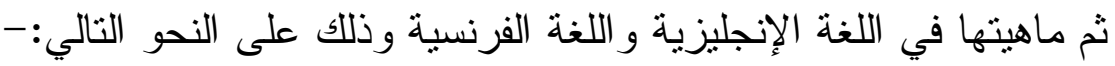

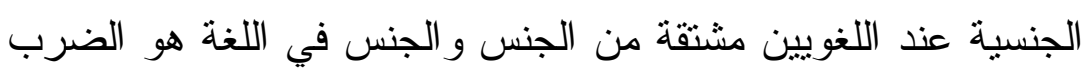

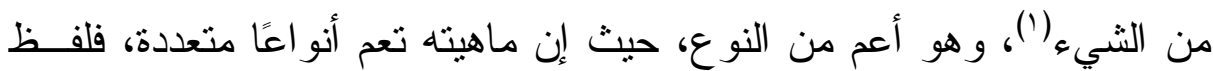

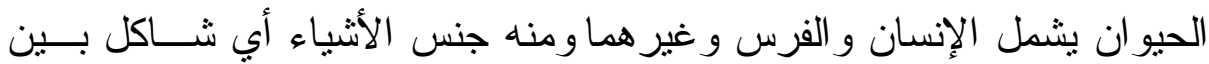

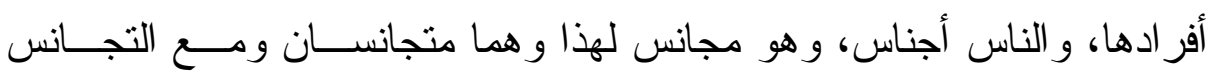

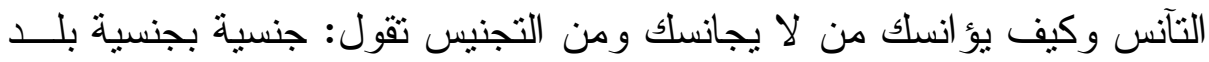

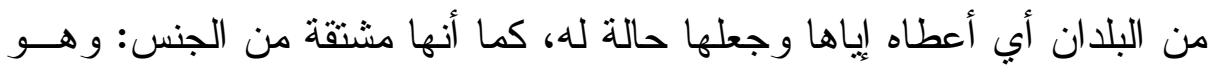

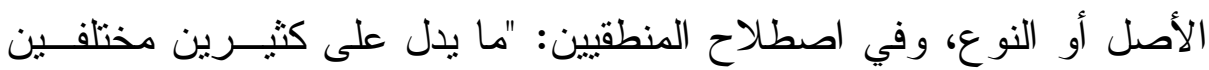

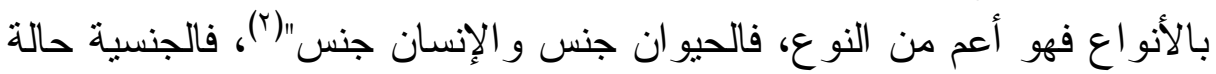

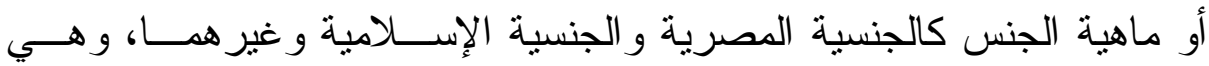

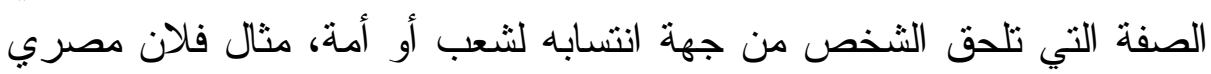

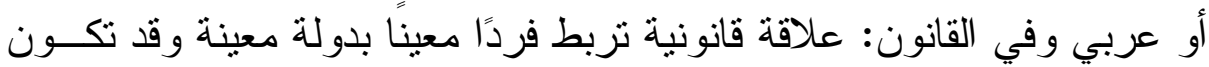

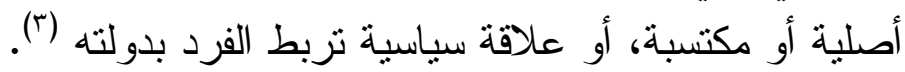

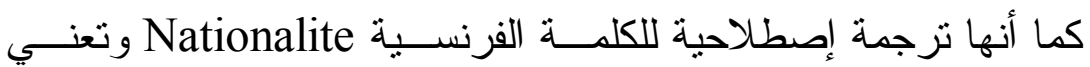

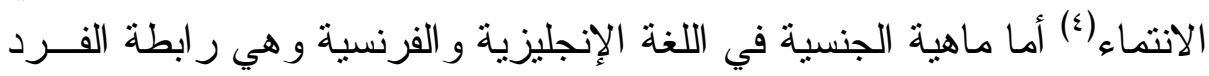

مختار الصحاح، لـحمد بن ابي بكر عبد القادر الرازي، الطبعة الأولــي، مطبعــــ

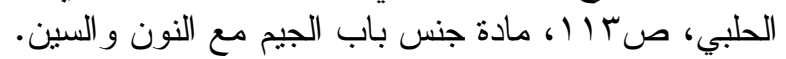

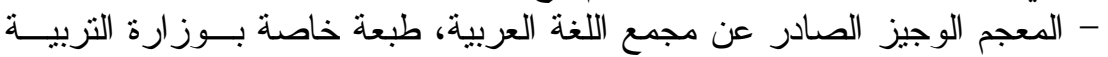

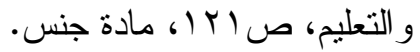

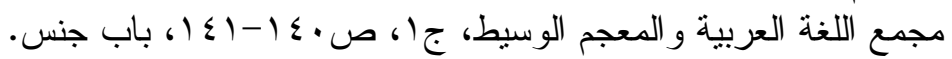
حسن الميمي: الجنسية في القانون التونسي، نون، التس، الثركة التونسية للتوزيع، بدون

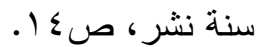
فالجنسية ترجمة إصطلاحية للكلمة الفرنسية Nationalite المشـتقة مــن كلمــة

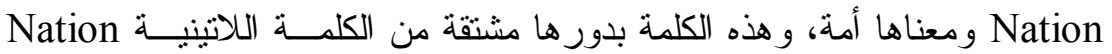

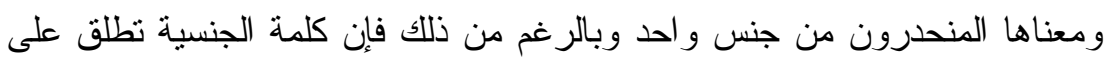

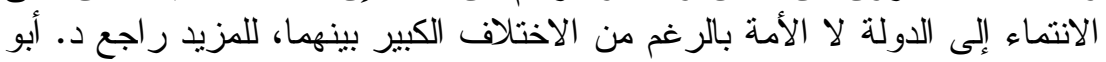


بالدولة يطلق عليها الجنسية وهي ترجمــة اصــطلاحية للكلمــة الإنجليزيــة Nationality

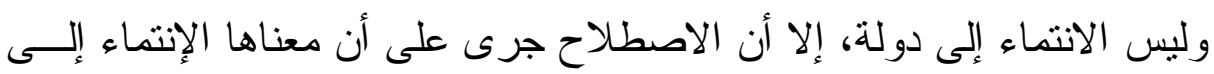

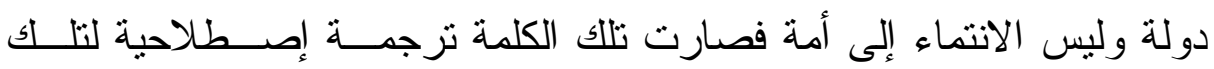

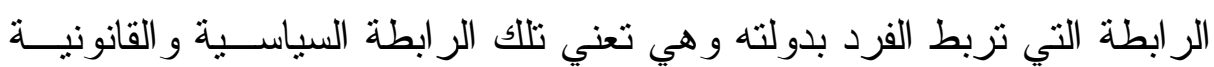
المستمرة التي تربط الفرد بالدولة.

وتقرض عليه نحو ها و اجبات معنوية كالطاعة و الو لاء وو اجبات مادية

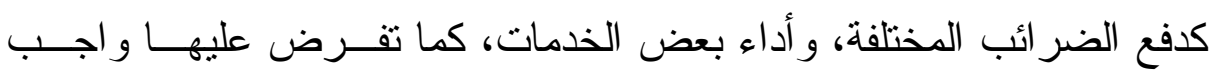
حمايته ور عاية شئونه.

\section{الاطلاب الثاني \\ ماهية البنسية في الفقه الإسلامي}

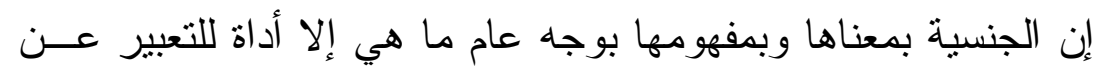

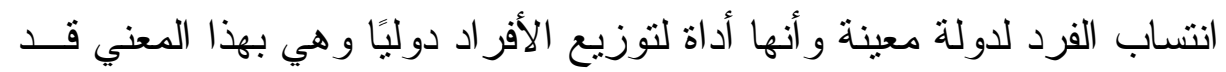

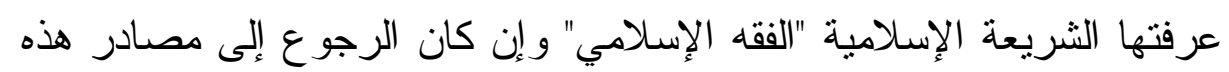

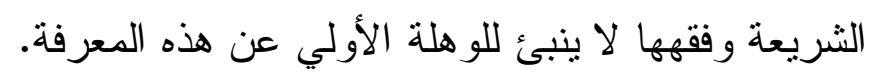

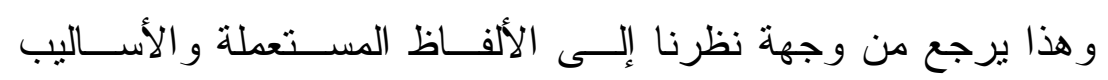

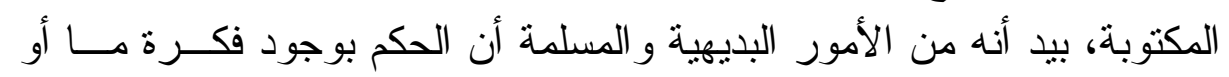

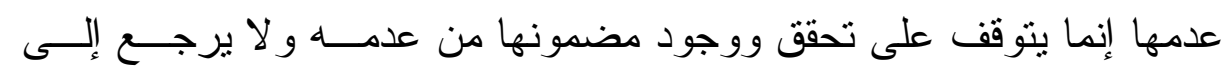

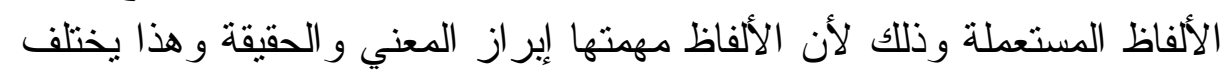

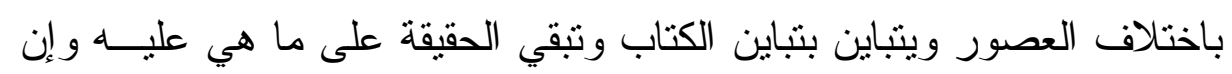
أخفق الباحثون في الوصول إليها.

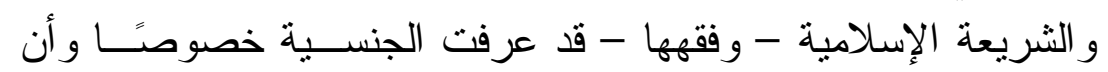

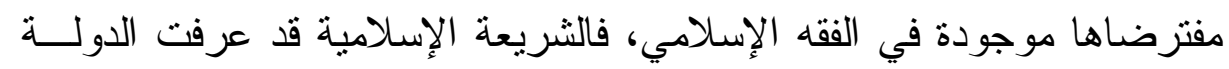

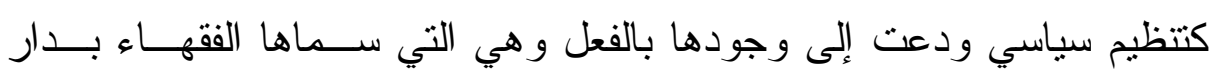

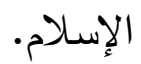

العلا أبو العلا النمر : النظام القانوني للجنسية المصرية وفقًا لأحكام القـانون رقـم

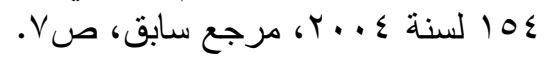

= إللالة على الجنسية في الققه الإسلامي والقانون الدولي الخاص 
- كما أن عناصر الدولة من شعب و إقليم وسلطة موجودة فـــي الفقـــــ الإسلامي وقد أفردت لبيانها العديد من الأبحاث و المؤلفات.

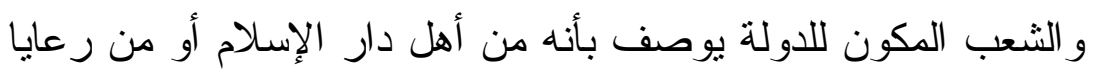

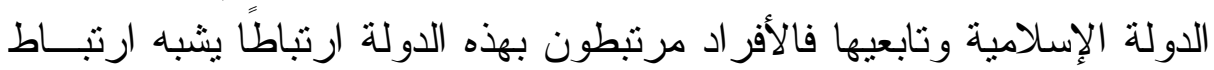

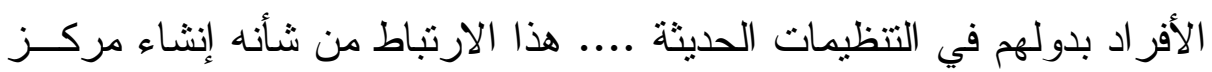

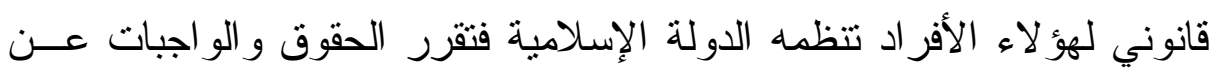

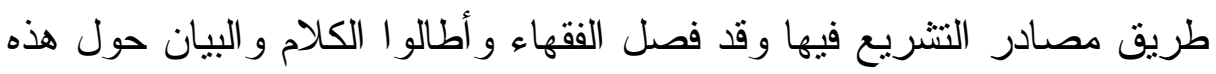
الحقوق وتلاك الو اجبات و الالتز امات.

- كما ذكر الفقهاء كيفية اكتساب الجنسية وأسباب فقدها - وذللك على التى

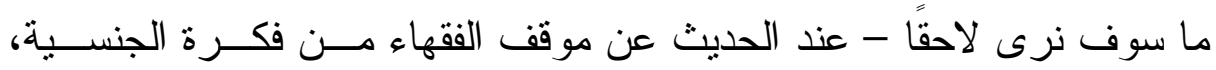
و الفقهاء و هم بصدد بيان ذلك لم بستخدمو الفظ الجنسية بل كانت لهم مســميات

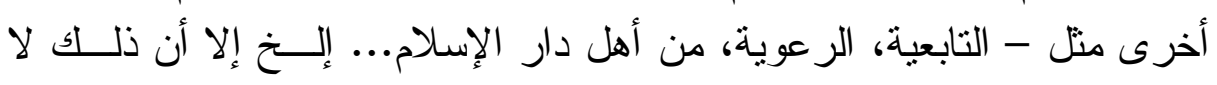
يعني عدم وجود هذه الر ابطة بين الفرد و الدولة.

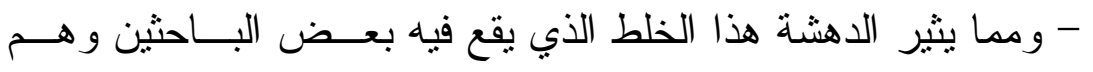
بصدد نظرتهم إلى الإسلام حيث يقصرونه على أحد جانبين له فقط و هما:-

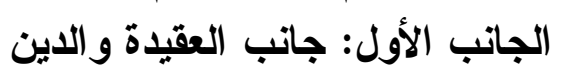

و هو في ذللك ينظم العلاقة بين الفرد وخالقه باعتبـــاره الإلــــهـ الخــالق الر ازق المتقرد بالعبودية، الموصوف بكل الكمال، و المنزه عن كل نقص و إليه يرجع الأمر كله، و إليه المآل و المرجع.... الخ و هذا الجانب و اضعح المعالم.

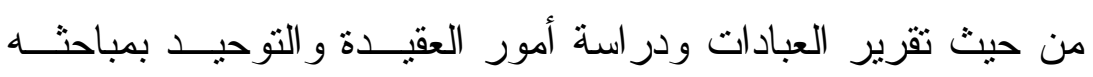
المختلفة.

$$
\text { الجاتب الثاني: جانب الثريعة - النظم }
$$

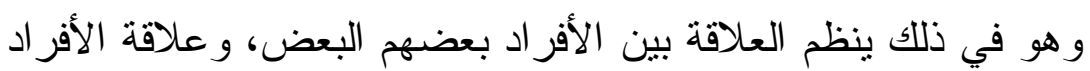

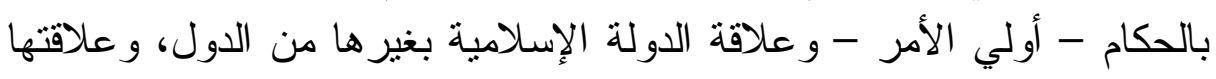

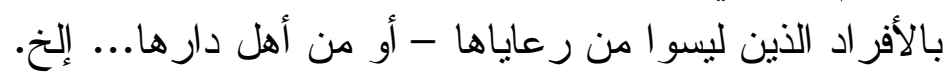

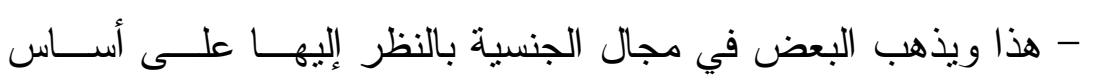

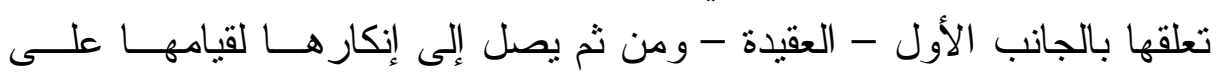


العقيدة، ولم برق هذا لدي البعض الأخر و الذي نظر إلبها على أساس تعلقهــا

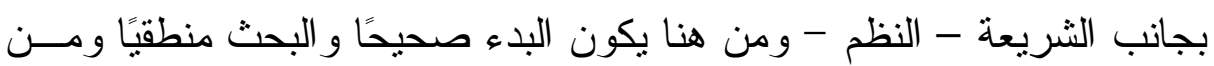

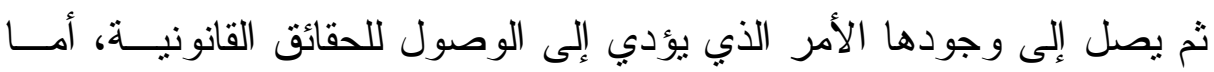

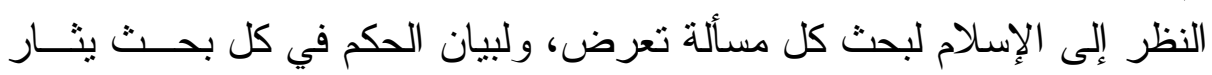

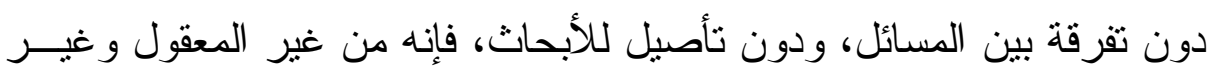

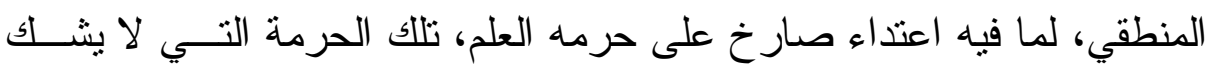
أحد في وجوب الحفاظ عليها و الدفاع عنها.

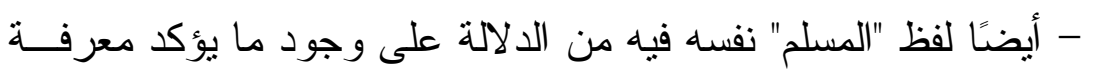

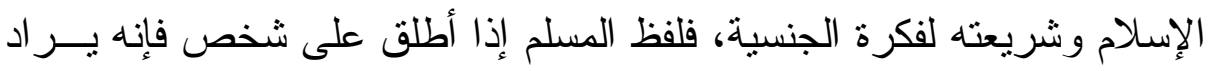

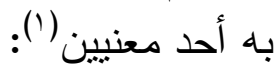

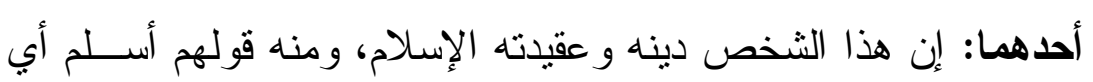
انقاد ودخل دين الإسلام، و الإسلام إظهار الخضوع و القبول، و الدين الذي أنزله

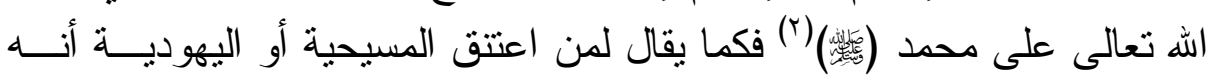
مسيحي أو يهودي بمعني أنه دينه وعقيدته المسيحية أو اليهودية فكذلك المسلم

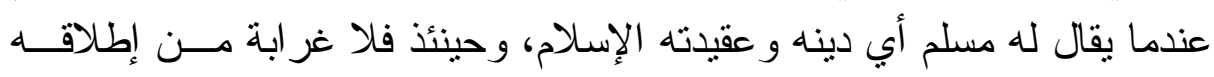

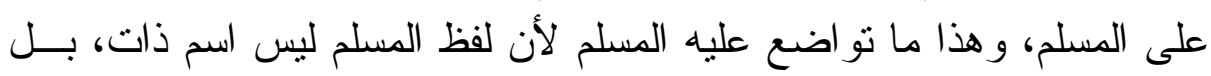

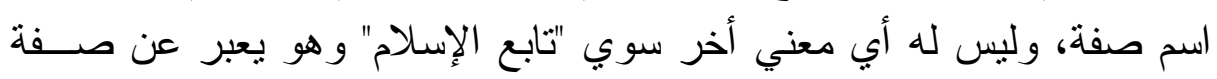

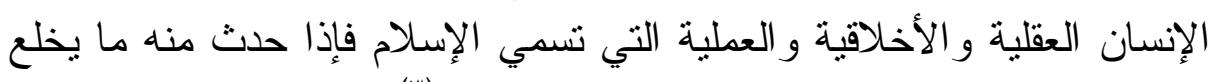

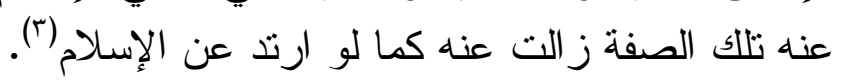

ثانيهما: أن هذا الثــخص منمتــع بجنســية دار الإســـلام - الدولـــة

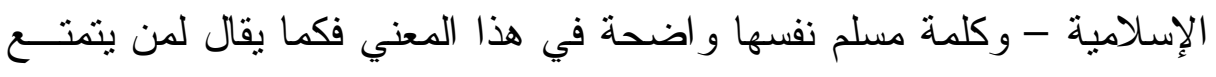

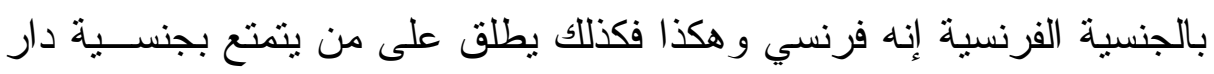

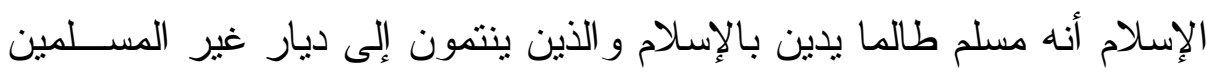

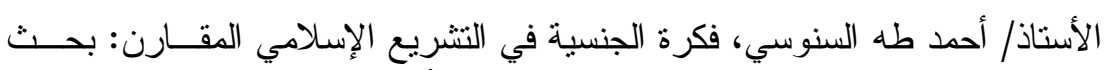

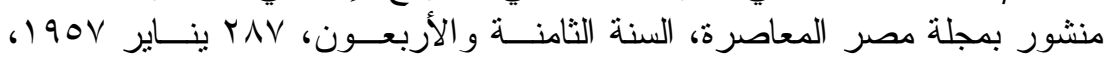

$$
\text { ص ع ع وما بعدها. }
$$

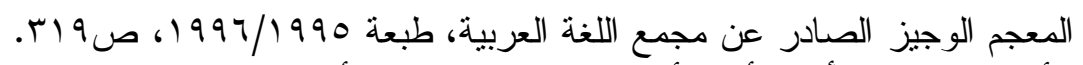
الأمة الإسلامية للأستاذ أبو الأعلى المودودي، لعندية لعريب أحمد إدريس، الطبعة الثانية، صT 


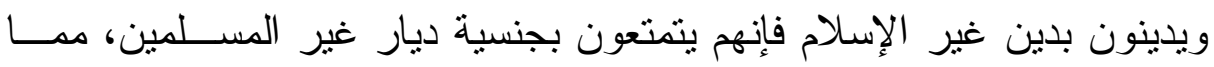
يستفاد منه معرفة الإسلام لفكرة الجنسية ويؤيد وجودها في الفقه الإسلامي.

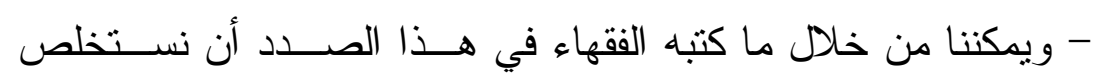

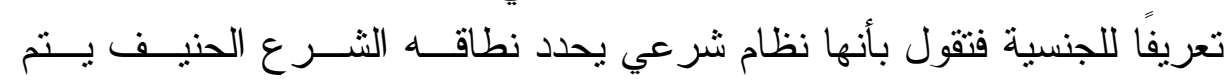
بمقتضاه تحديد المركز القانوني للمسلم و التمبيز بينه وبين غيره، فالتعبير بلفظ

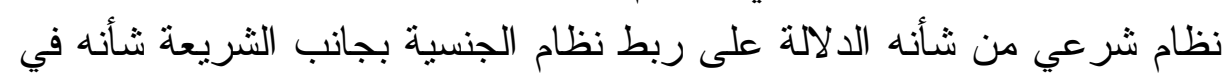

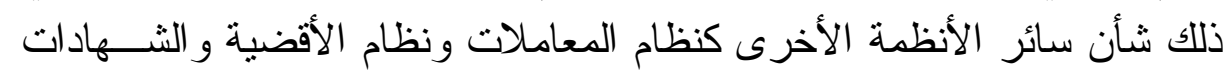

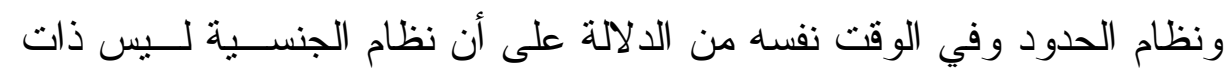
طبيعة عقدية أو اتفاقية و التعبير بلفظ يحدد نطاقه الثر ع الفيه من الحنيف من شأنه بيان

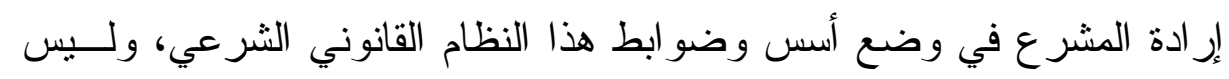

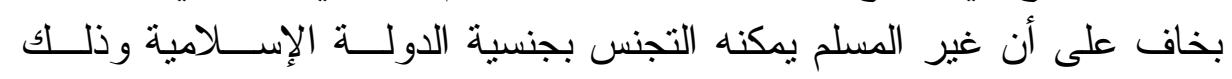
بشروط معينة.

- ـ التعبير بلفظ يتم بمقتضاه تحديد المركز القانوني للمسلم و التمييـز

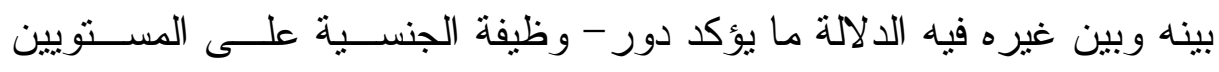

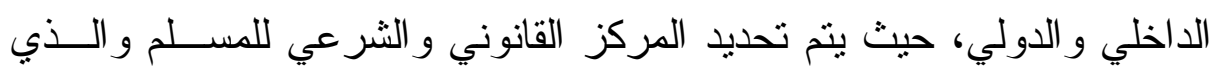

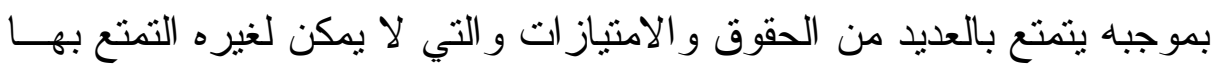

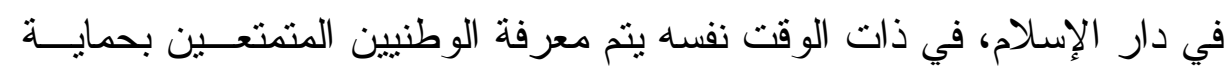

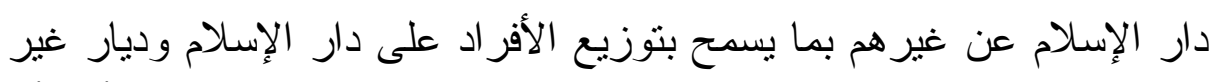

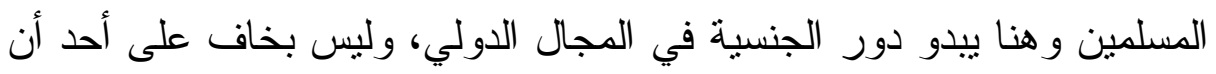

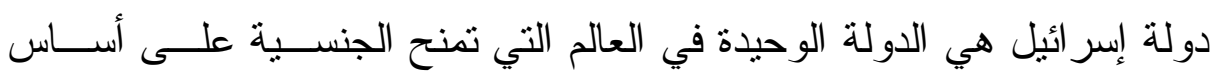

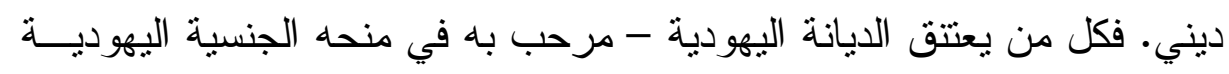
دون نزدد.

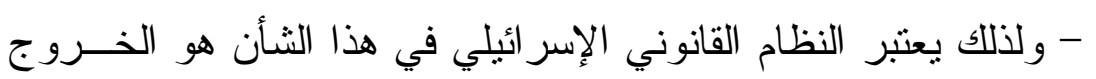

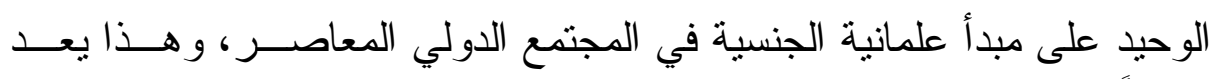

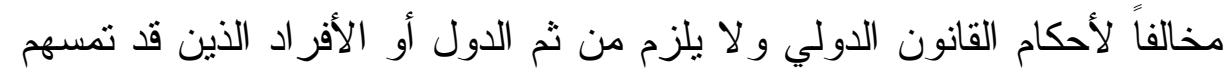

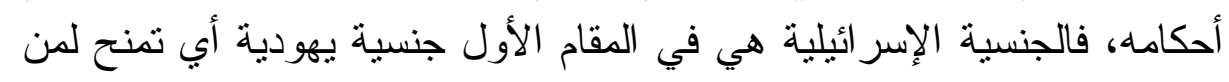

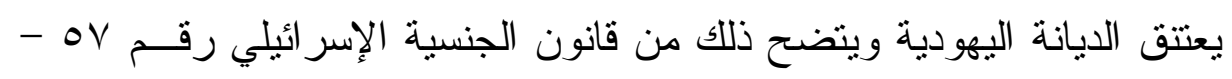


r السنة 90 1 19 وقانون العودة الإسر ائيلي رقم OV - - . لسنة . 90 ام وهما القانونان المكونان لنتريع الجنسية الإسر ائيلية.

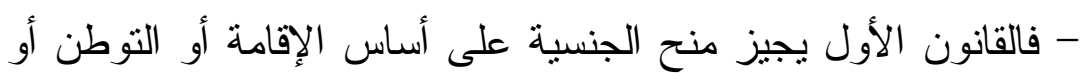

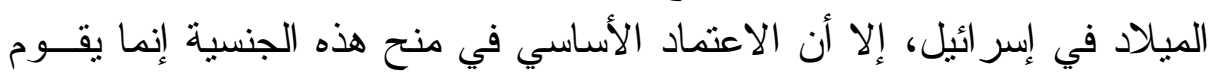

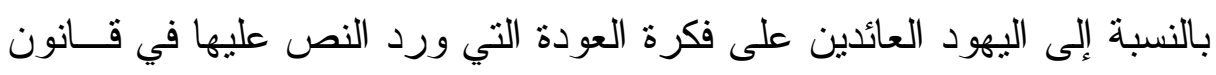

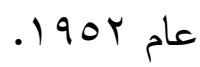

و الجنسية الإسر ائيلية وفقاً لهذه السياسة محجوزة لليهــود المهــاجرين

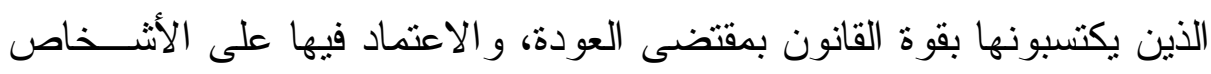
المنتمين للايانة اليهودية يمنل العامل القاطع في استمر ار تضخم سكان إسر ائيل

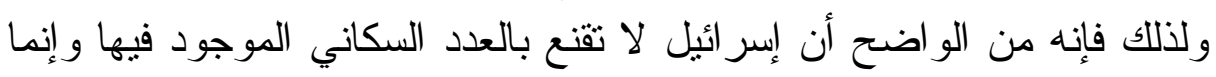

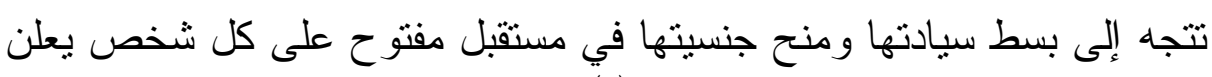
انتمائه إلى اليهودية مهما كانت دولته (').

وتتعارض الجنسية الإسر ائيلية مع عالمية الديانة اليهوديـــة بالإضــافة

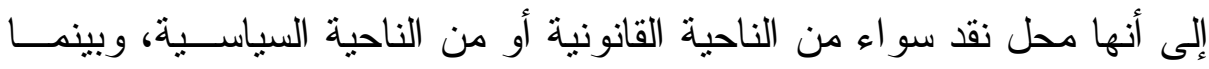
تتميز الجنسية - بالمفهوم القانوني - بالتحديد و الانضباط، نتف النق الجنسية الدينية

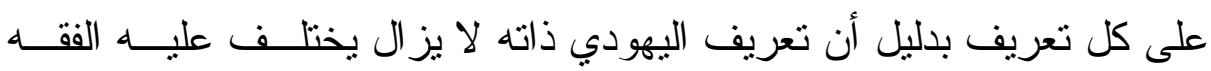
و القضاء الإسر ائيليين اختلافاً كبير اً.

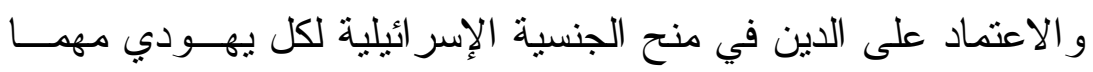

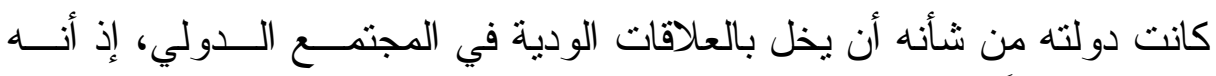

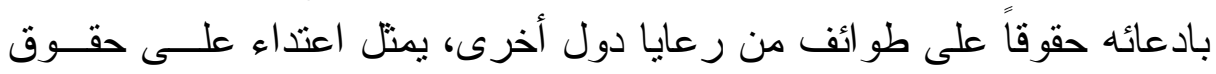

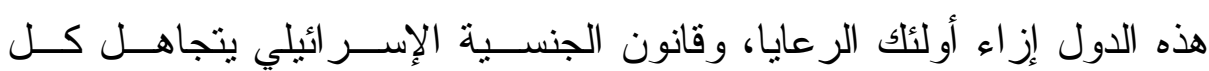

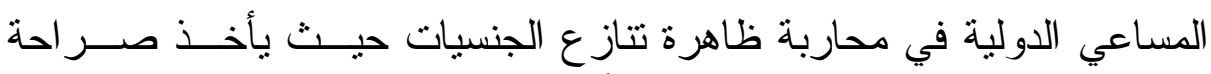
بإمكانية ازدو اج الجنسية وتعددها جاعلاً منها أحد اتجاهاته الرئيسية.

د. أحمد قسمت الجداوي: القانون الدولي الخاص، الجزء الأول في الجنسية ومركز

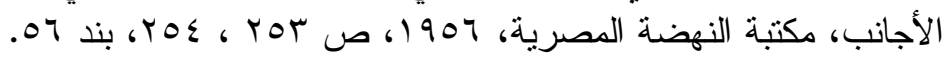

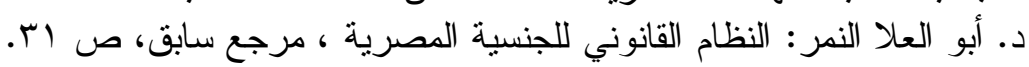




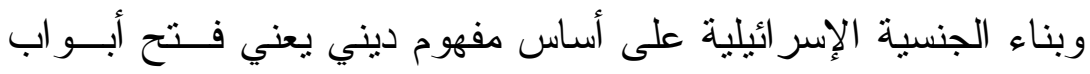

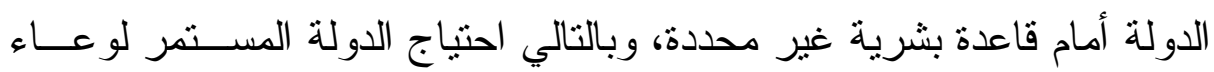

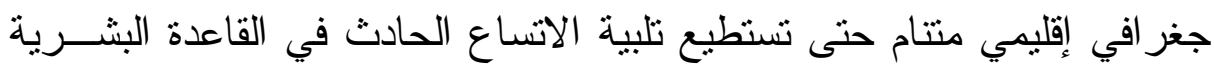

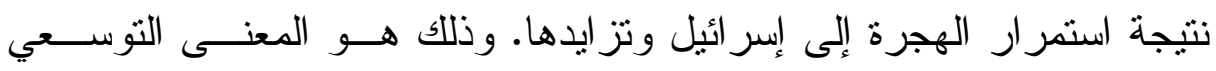

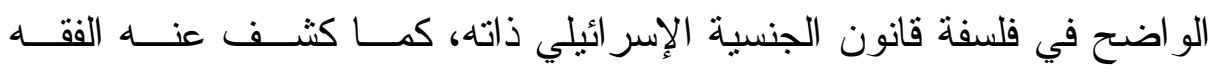
الإسر ائيلي بصر احة قائلين أن المرونة التي تتسم بها نصوص هذا الجية القانون في

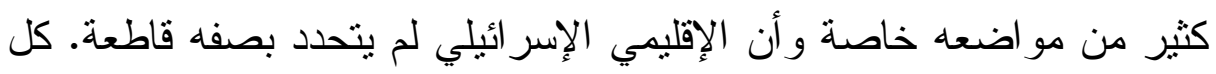
ذلك يسمح في المستقبل بالتمسك بتقسير من مؤداه أن كل من ولد في أبي إقليم

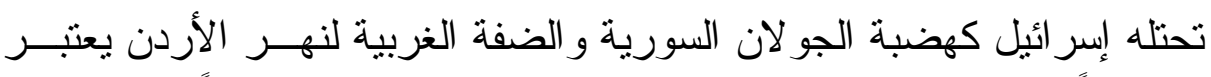

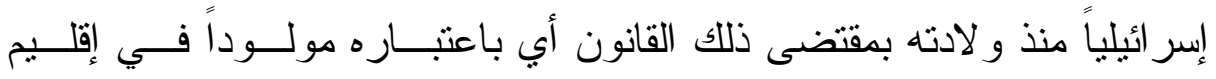

إسر ائيلي (')

ويرى جانب فقهي معتبر أن إسر ائيل قد نشأت نتيجة لأوضاع سياسية

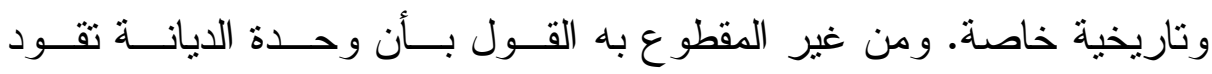

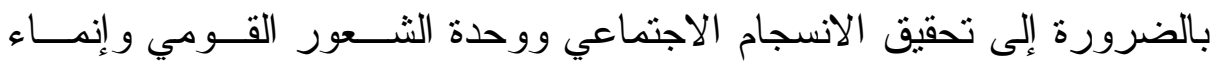

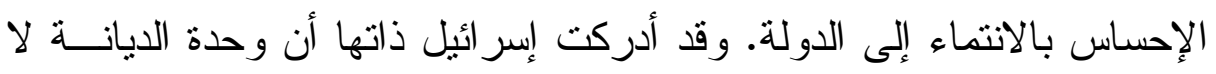
تكفي لصهر و إدماج المهاجرين المختلفي العادات و اللغات، فعددت إلى إلى إحيــاء

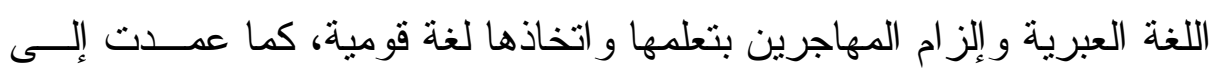

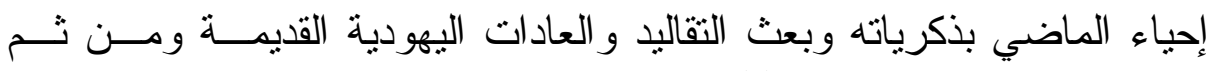
الدخول في حلبة الصهيونية (؟).

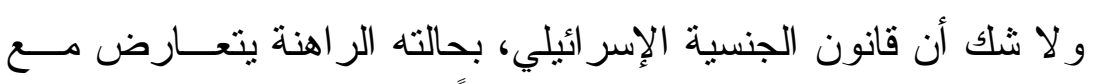

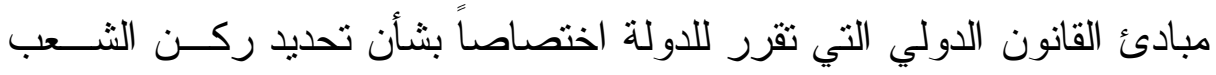

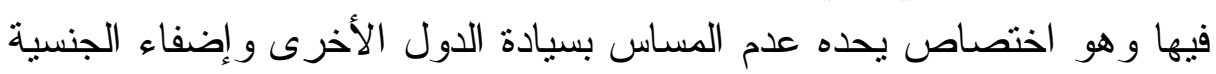

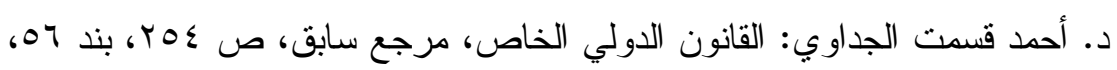

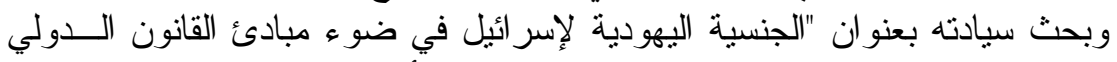

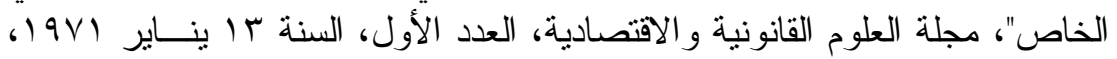

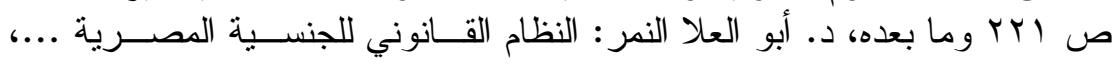

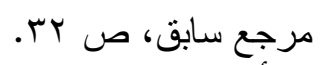

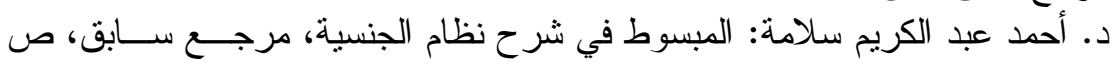

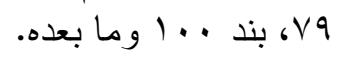


الإسر ائيلية على كل يهودي يعود إلى إسر ائيل من شأنه الافتئات علــى ســيادة

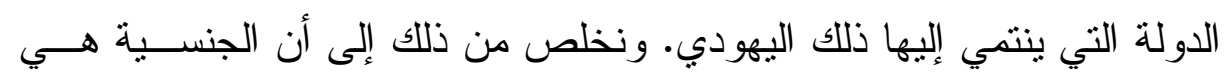

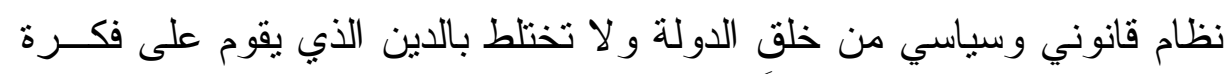
معنوية اعنقادية وتتصل أساساً بالجانب الروحي ولئ ولاني الخلقي.

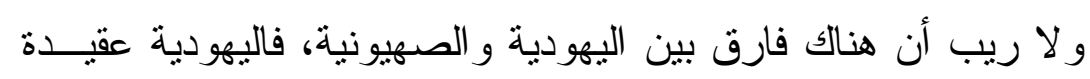

دينية، أما الصهيونية فهي مذهب سياسي، و عليه فكون المصري يهودي الديانة

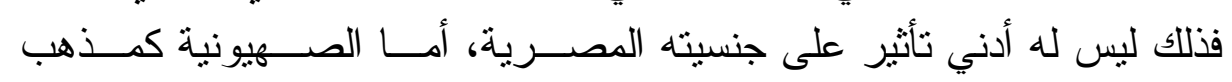

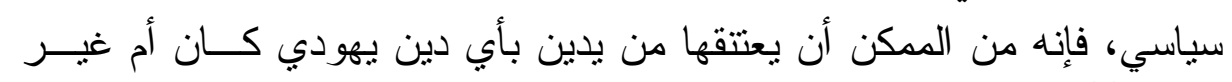

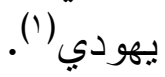

و غني عن البيان أن من بين حالات إسقاط الجنسـية فـي النتــريع

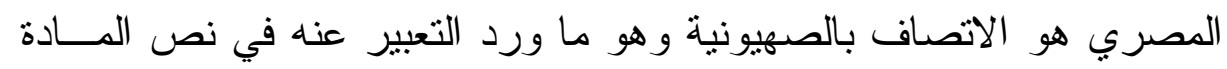

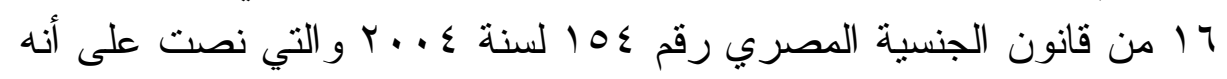

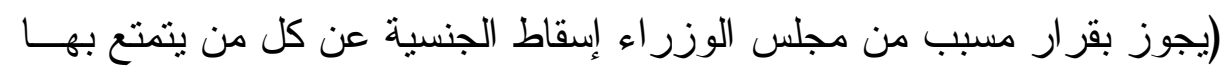

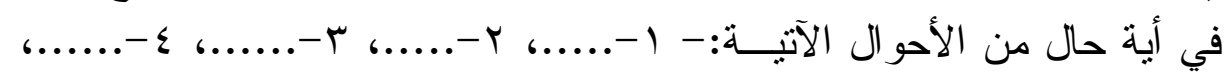

$$
\text { 6......-7 } 6 . . . . .00
$$

\section{V - إذا اتصف في أي وقت من الأوقات بالصهيونية.}

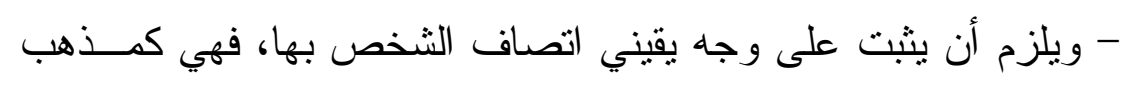
سياسي قو امه ر ابطة روحية ومادية تقوم بين من بتصف بها وبه وبين إبــر ائيل،

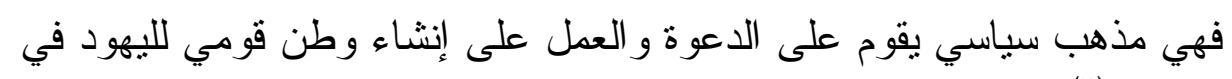

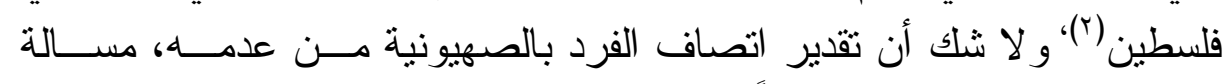
تخضع لسلطة جهة الإدارة وفقًا لظروف وملابسات كل حالة على حدة.

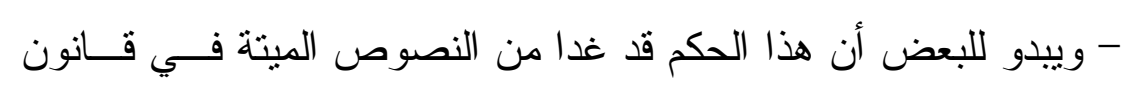

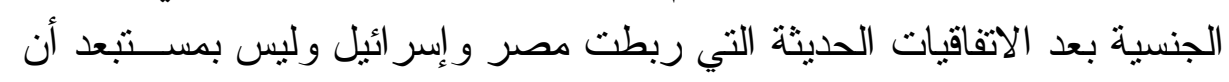

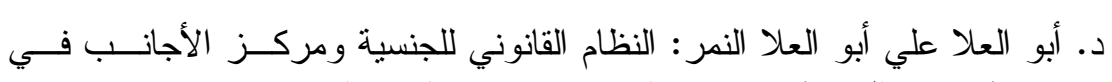

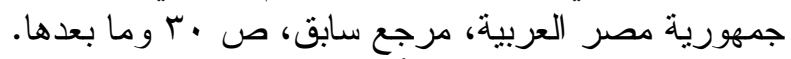

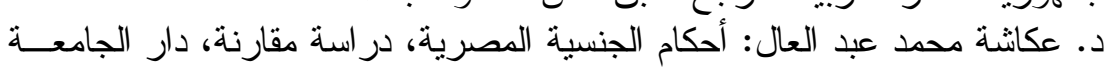

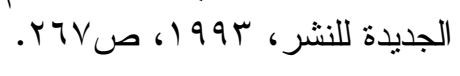


تصدر نصوص قانون الجنسية عند تعديلها خلوًا منه(') في حين بري جانـبـ

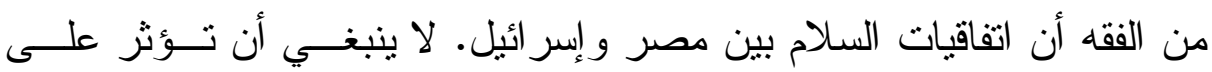

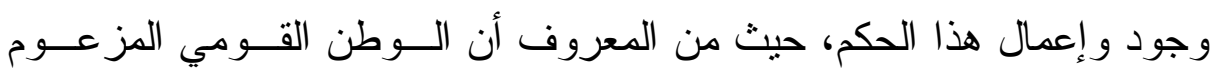

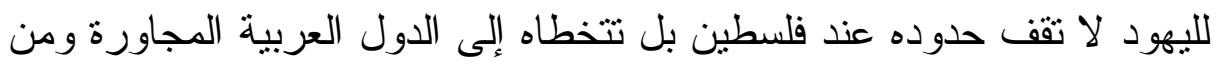

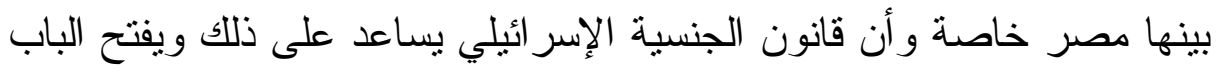

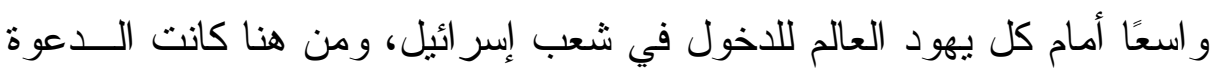

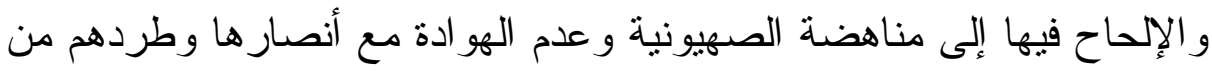

الجماعة المصرية بإسقاط الجنسية عنهم(ب).

\section{الإنبب الثالث}

\section{ماهية البنسية لدي فقهاء القانون الدولي الغاص}

حقيقة الجنسية في القانون الاولي:

الدولة هي التي تمنح الجنسية وتتظمها بما يحقق مصلحتها، و لا يجوز

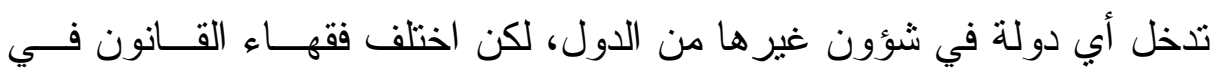

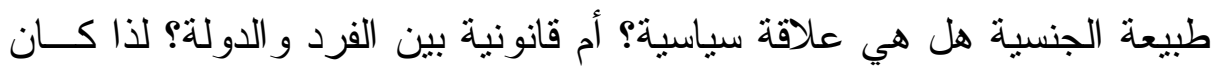

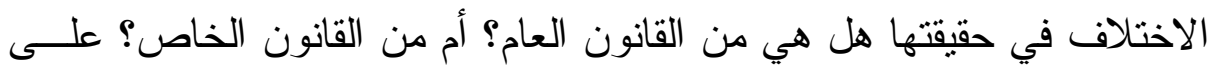
النحو التالي: - n

ا - الجنسية من القانون العام: ذهب فريق من أهل القانون إلى القول

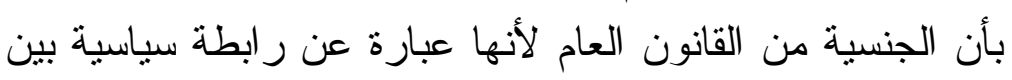

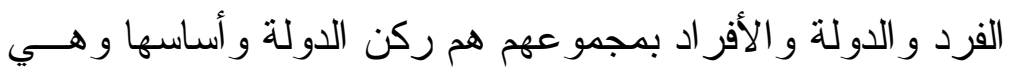
النظام القانوني الذي يتحدد به عنصر الفرد بالدولة|(؟).

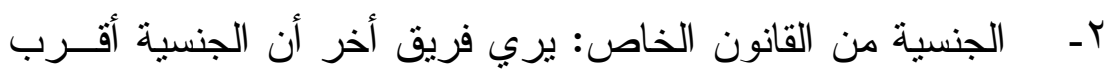

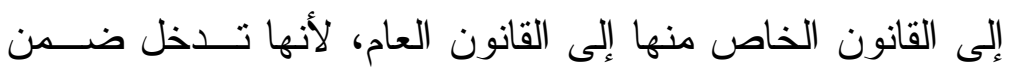

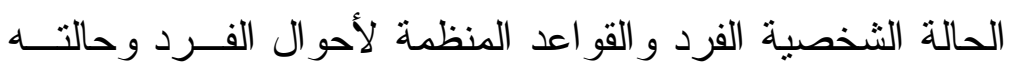

د. أحمد عبد الكريم سلامة، "المبسوط في شرح نظام الجنسية" دار النهضة العربية،

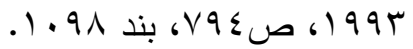

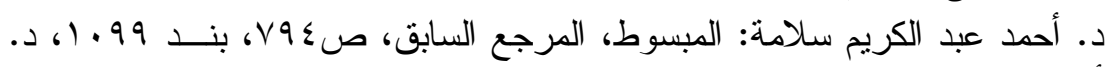

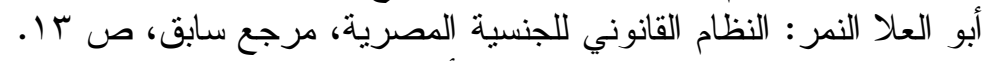

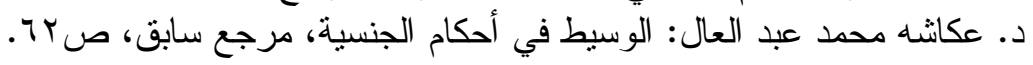

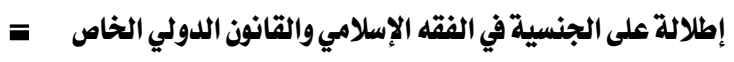


القانونية هي أقرب إلى القانون الخاص، و الجنسية هي التي تحدد حقوق الفرد وو اجباته وتعطيه الصفة القانونية (').

$$
\text { ويحتج أنصار هذا الفريق بما يلي:- }
$$

أولا: بما أن الجنسية أهم عناصر الحالة الثخصية للفرد فهي تبني على أساس

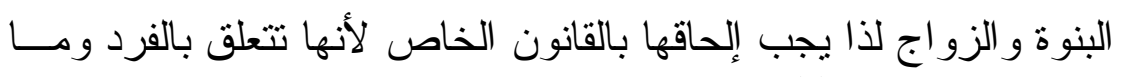

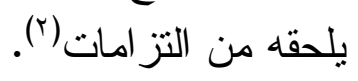

ثانيًا: الدولة لا تمنح الفرد الجنسية رغمًا عنه و لا تتجاهل إر اداته في كسبها أو

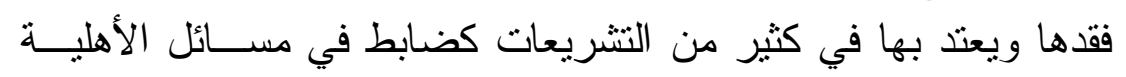

$$
\text { و الزو اج و غير ها"َ). }
$$

\section{حقيقة الجنسية في الإعلان العالمي لحقوق الإنسان}

لقد نصت العديد من المو اثثق الدولية على حق كل فرد فــي اكتشــاب

$$
\text { جنسية دولته و عدم جواز حرمانه منها. }
$$

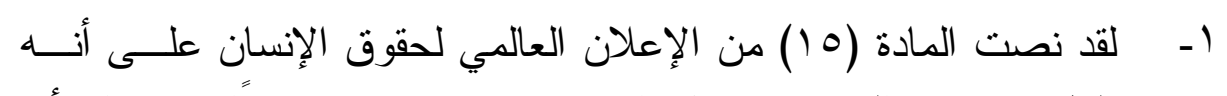

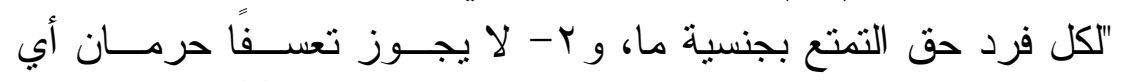
شخص من جنسيته و لا من حقه في تغيير هذه الجنسية" (ई).

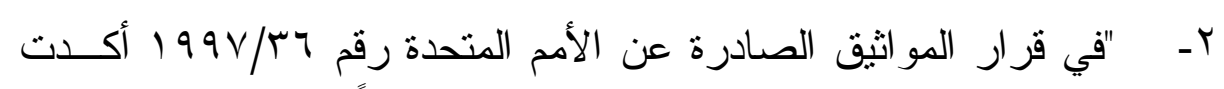

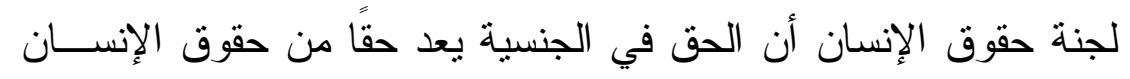

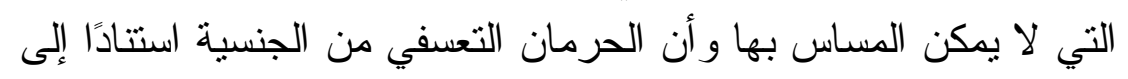

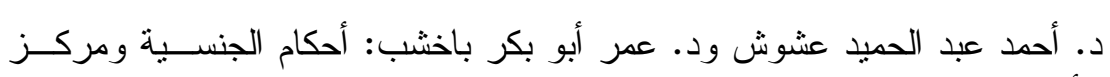

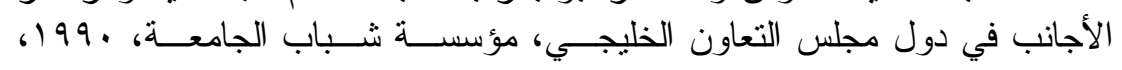
صT. 1.

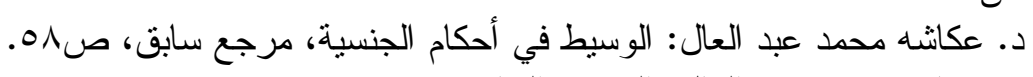

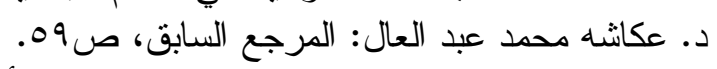

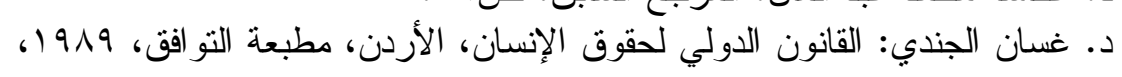
ص. د. 
أسس عنصرية أو دينية يثكل انتهاكِّــا لحقــوق الإنســان و الحريــات

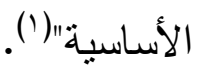

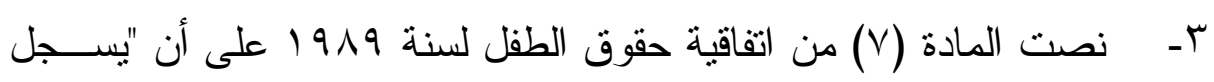

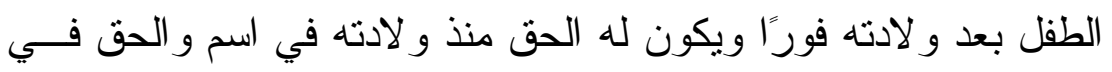

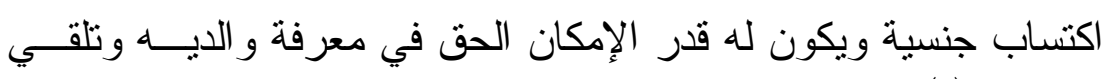

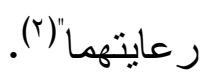

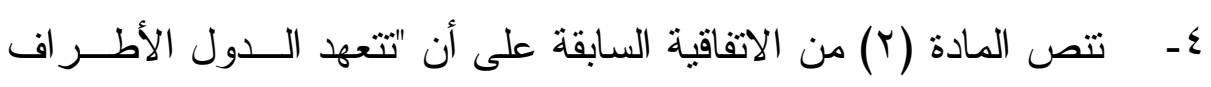

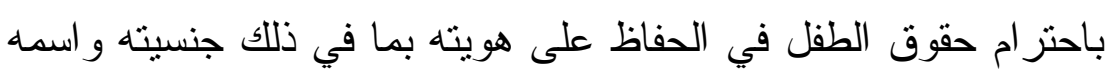

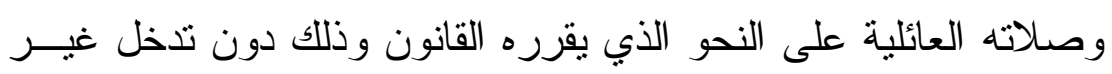

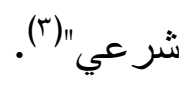

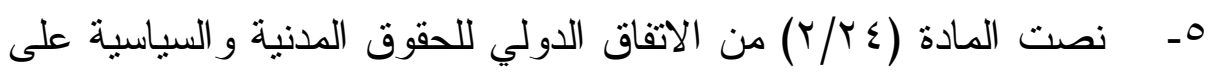

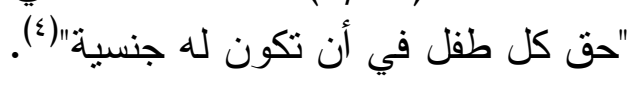

- هذه النصوص قد أكدت على أن منح الجنسية حق من حقوق الإنسان

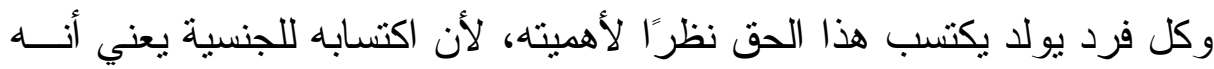

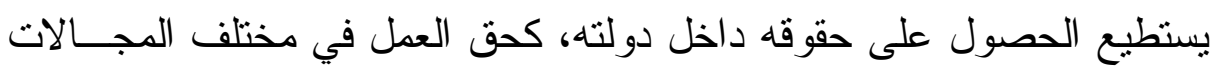

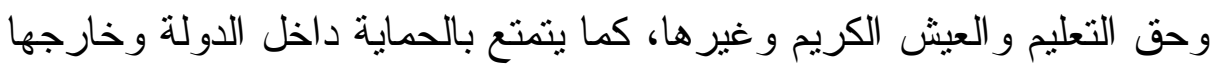

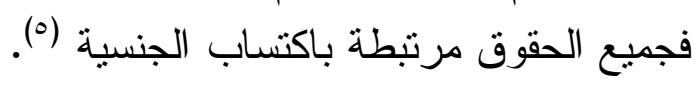

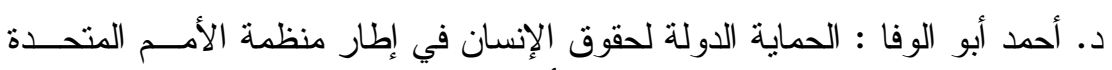

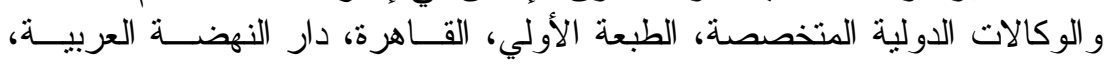

$$
\text { ( I... P }
$$

سعيد بن سلمان العبري : القانون الدولي وحقوق الإنسان قديمًا وحديثًا، دار النهضة

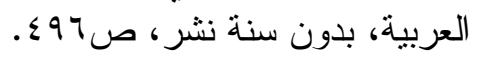

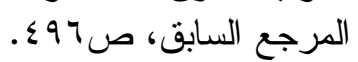

غازي حسن صباريني: الوجيز في في حقوق الإنسان وحريته الأساسية، الطبعة الثانية،

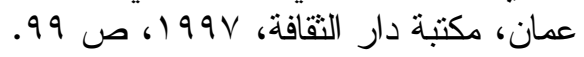

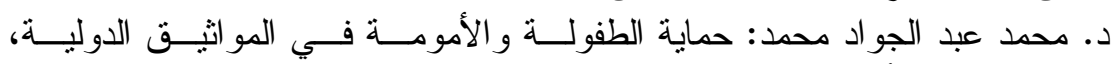

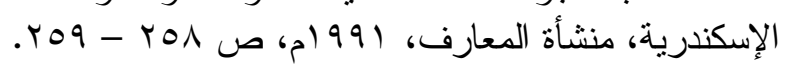


- وبعد أن ذكرت بعض النصوص القانونية التي تؤكد علــى ضــرورة

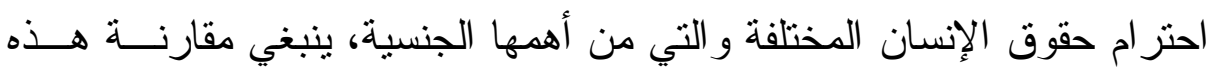

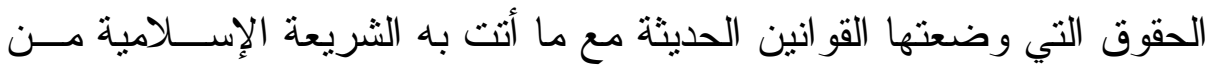
حقوق وكيف كفلت للإنسان حقه في مختلف مجالات الحياة، فأقول أن الإسلام

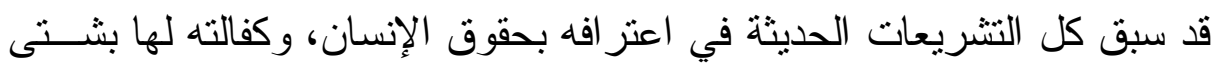

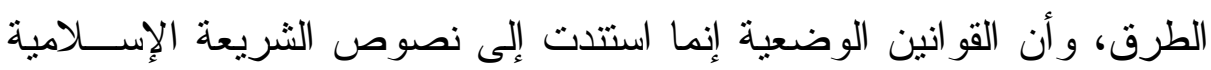

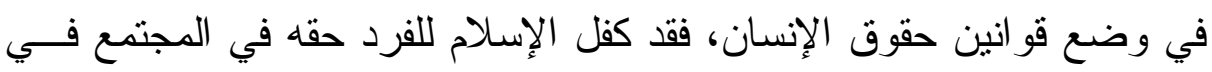

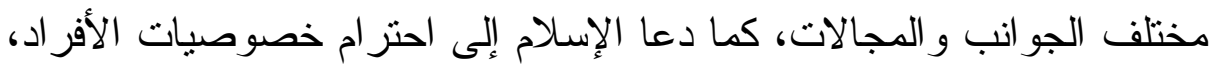

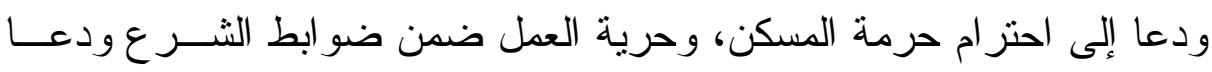

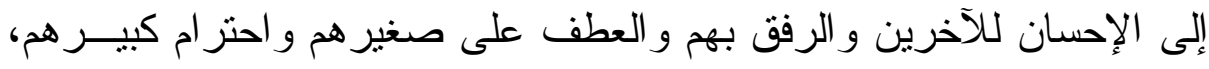

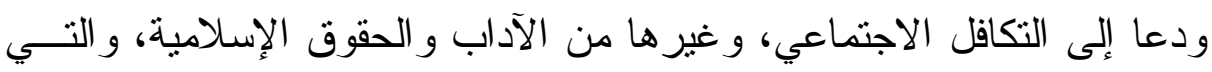

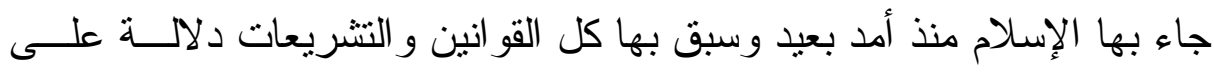
عظم هذا الدين وشموله و عالميته.

- ومن المتفق عليه لدي فقهاء القانون الدولي الخــاص أن الجنســية

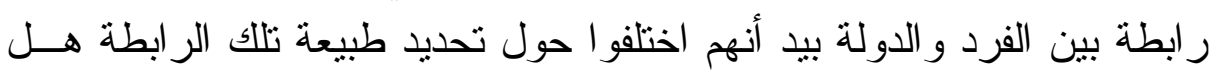

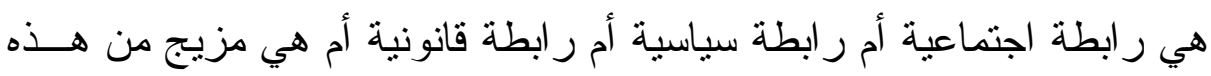
الرو ابط.

- ولعل السبب في تعدد التعاريف التي قيلت بشــأن ماهيـــة الجنســــة

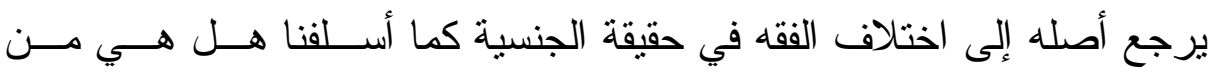

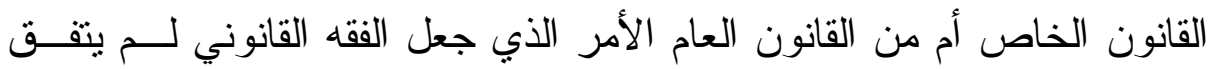
على مدلول موحد لفكرة الجنسية.

وقبل أن نخوض في الاتجاهات التي تعرف الجنسية وهو ما ســنوجزه في المبحث القادم بإذن الله. سنتحدث عن أهمية الجنسية بالنسبة للدولة و الفرد. 


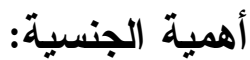

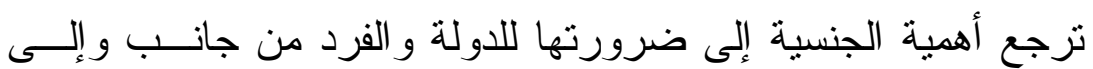
أهمية الآثار القانونية التي تترتب عليها من جانب أخر، وبيان ذلك أن الجنسية تعتبر بحق الأساس الذي يقوم عليه كيان الدولة|('). - فالدولة توجد بو اسطة الأفر اد الذين يكونونها و إذا كان من الممكــن

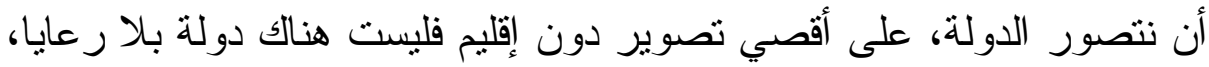
ومن ثم يتعين على كل دولة أن تضع القو اعد التي بمقتضاها تحدد من الأفراد من يعتبر من مو اطنيها.

- و على هذا تعتبر الجنسية أداة توزيع البشر بين الدول المختلفة فعـن

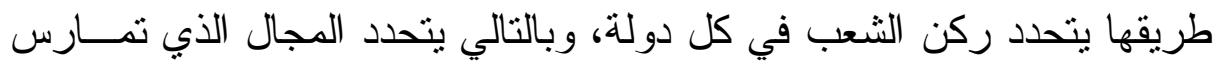

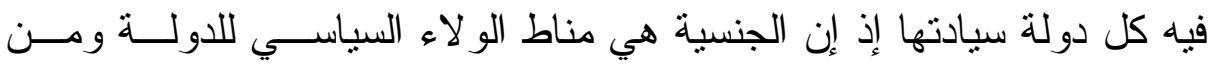

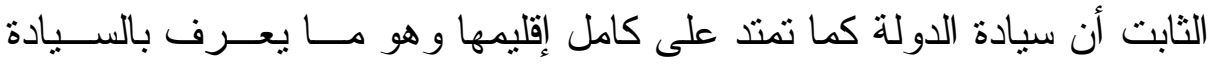

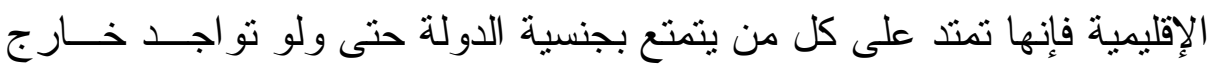
الإقليم وهو يطلق عليه السيادة الشخصية للدولة.

ويلاحظ أن القانون الدولي العام لا يعترف للفرد بشخصـيـة قانونيـــة

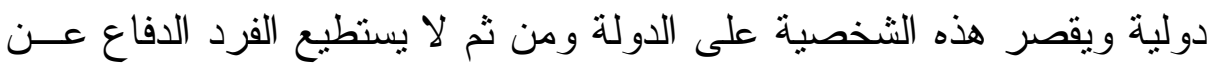

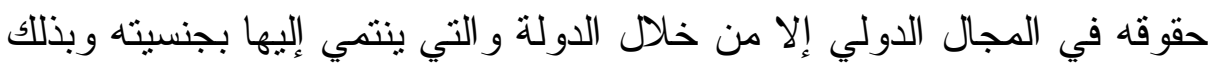
تعد الجنسية الوسيلة القانونية لحماية الفرد في المجتمع الدولي وتستطيع الدولة

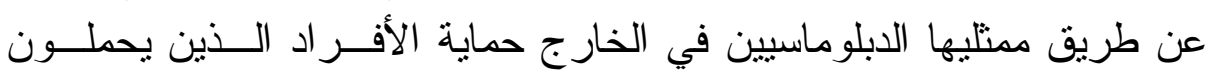
جنسيتها و الدفاع عن حقوقهم حتى وإن أقامو ا خارج الدولة (؟). - وفي مجال القانون الداخلي تظهر أهمية الجنسية للفرد إذ بمقتضاها يمكن التمييز بين شعب الدولة وسكانها فمن يحملون جنسية الدولة يدخلون في

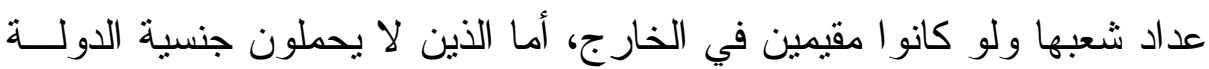
ويقيمون في أرضها فهم من الأجانب ويدخلون بهذا الوصف في في عداد سكانها.

د. أبو العلا على أبو العلا النمر : النظام القانوني الجنسية المصرية وفقَّـا لأحكــام

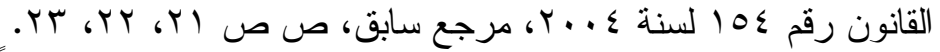

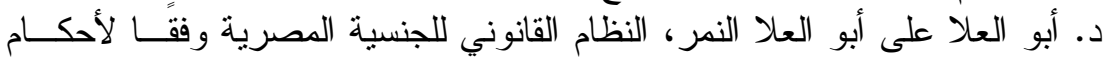

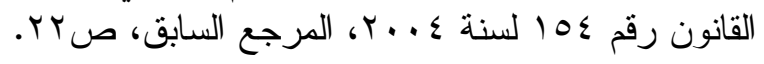


- وللتمييز بين هاتين الطائفتن أثار قانونية هامة، فالنظام القانوني في

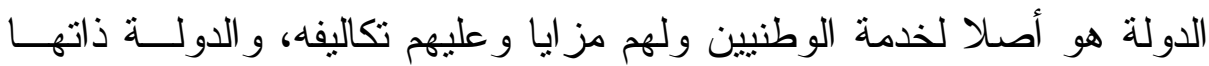

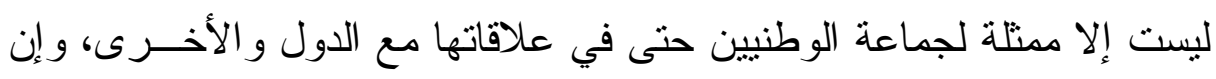

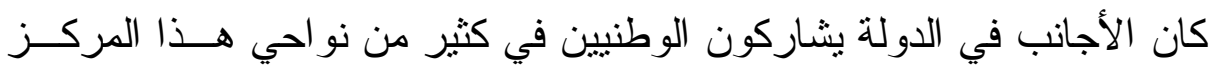

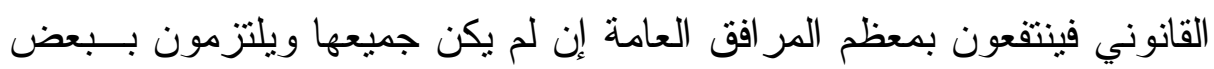

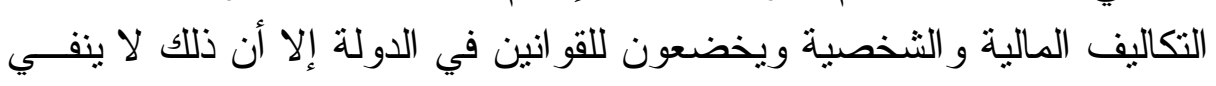

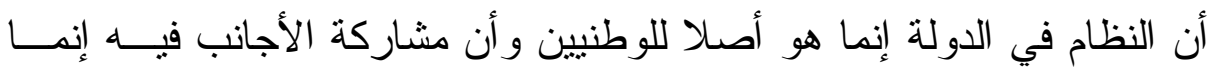

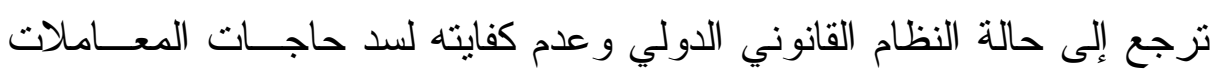

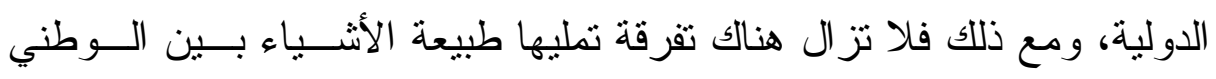
و الأجنبي في المركز القانوني.

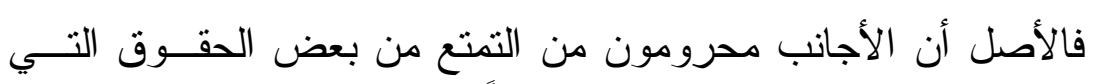

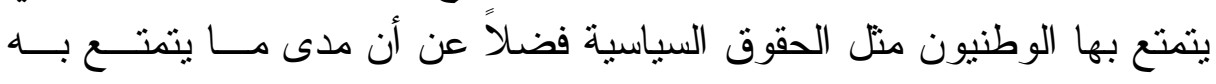

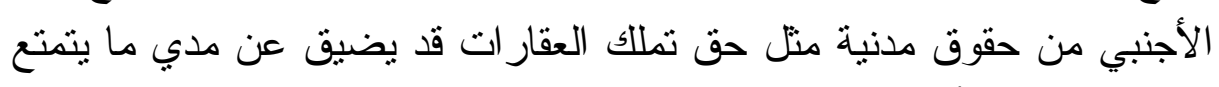

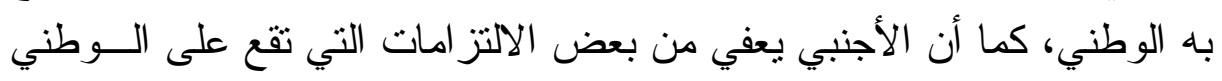

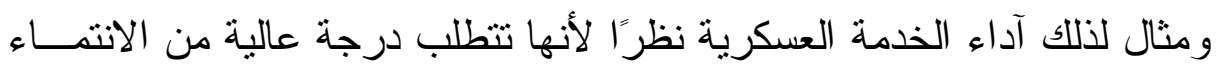

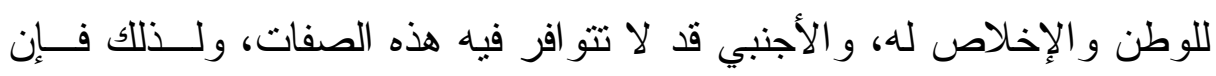

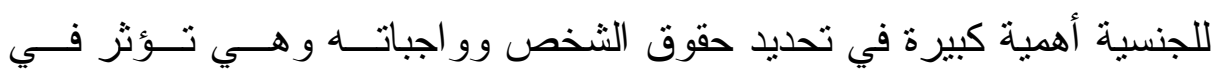

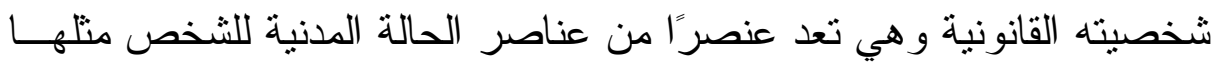
في ذلك مثل الحالة العائلية.

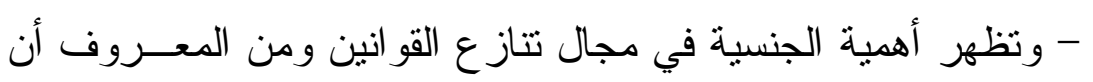

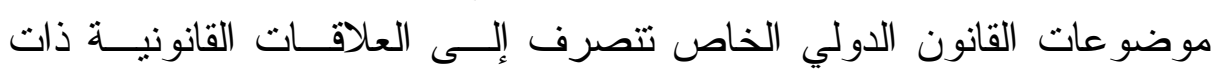

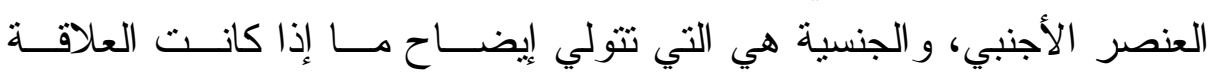

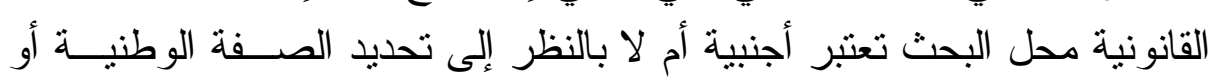

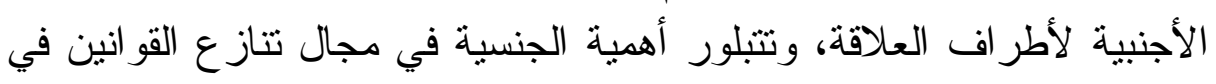


تحديد القانون الشخصي من خلال ضابط الإسناد وهو الجنسية وهو ما تعتد به

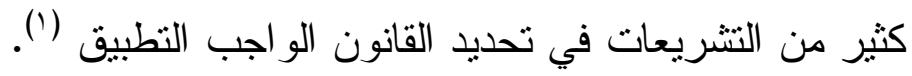
وتظهر أهمية الجنسية في مجال الإختصاص القضائي الــدولي حيــث

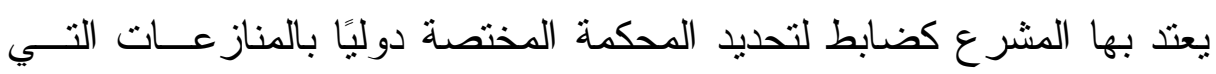

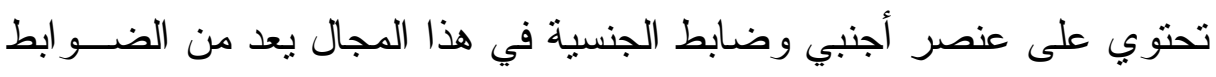
الثائعة في القانون المقارن.

د. إبر اهيم حسن محمد عمر الغزاوي: المركز القانوني للطفل في مجــال القـانون

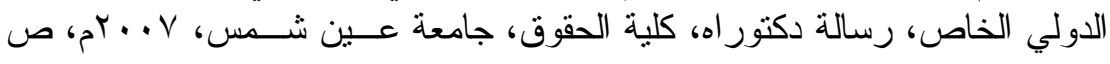
. $r \varepsilon$. 


\section{المبمث الثاني}

\section{آراء الفقهاء في القانون الدولي الخاص تباه الجنسية وتقدير هذه الآراء}

لا ريب أن هناك فرق بين الجنسية و القوميــة يتحــدد علــى أســاس الاختلاف المعروف بين الدولة والأمة.

و هناك العديد من الآر اء تجاه الجنسية في القــانون الــدولي الخــاص وفوارق بين الجنسية و القومية نتتاولها على الأجاه النحو التالي:

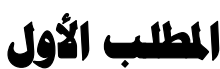

\section{الاتجاهات الفقهية تهاه المنسية وتقديرها}

هناك العديد من الاتجاهات في تقدير مسألة الجنسية نوردها فيما يلي:

الاتجاه الأول: هذا الاتجاه بز اوج بين الجنسية والأمة فيربط فكــرة الجنســية بفكرة الأمة ويعرف الجنسية بعدة تعاريف منها:-

- أن الجنسية هي وصف في الثخص يفيد كونه عضوًا في أمة معينة

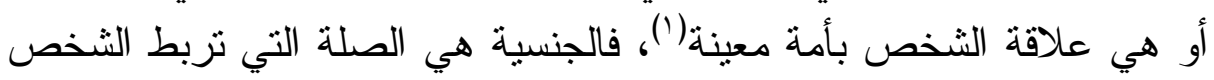
بأمة معينة. تقدير هذا الاتجاه:

هذا الاتجاه له فضل التركيز على الجانب الإجتماعي في الجنسية حينما

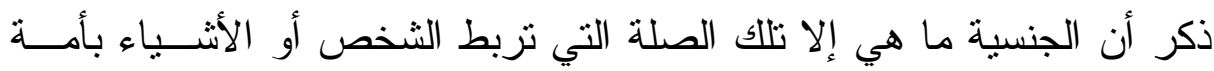
معينة ولكن يؤخذ عليه عدة أمور منها:

1 - أن الجنسية رابطة بين الفرد و الدولة لا بين الفرد و الأمة، و إن كــان

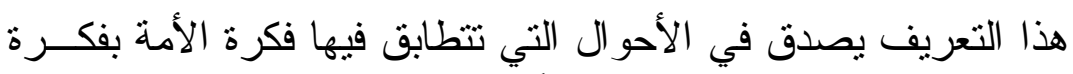

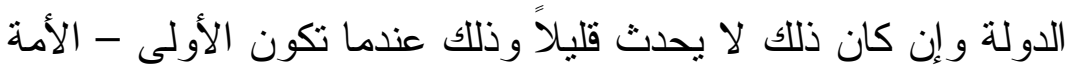

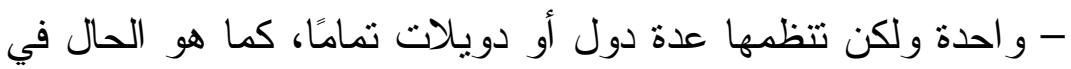

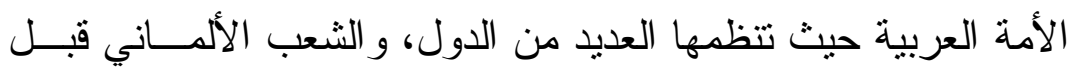

د. محمد عبد المنعم رياض: مبادئ القانون الدولي الخاص، مطبعة مصر الحــرة، سنة سبو ال، ص ل0د وما بعدها.

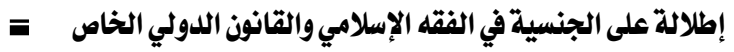


التوحيد كان مشتتا بين ألمانيا الشرقية و الغربية، وقد تكون الثانيـــة -

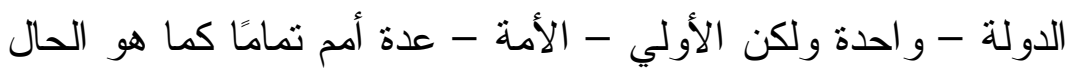

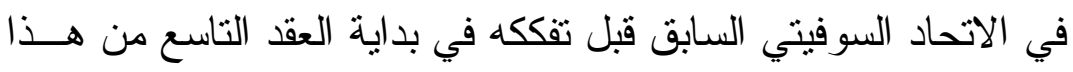

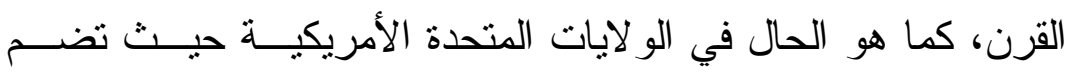

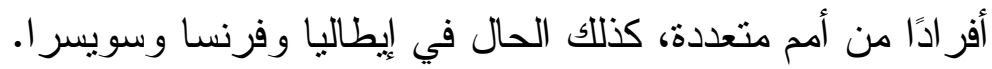
r- الجنسية ليست وصفًا في الثخص إنما هي رابطة بينه وبين الدولــة التي يحمل جنسيتها.

r- إن الجنسية باعتبار ها رابطة بين الفرد و الدولة إنما هي رابطة قانونية

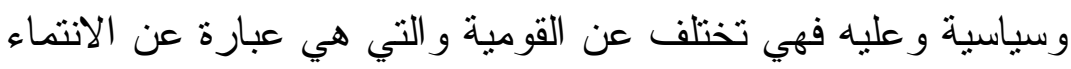
بين الفرد و الأمة فهي رابطة اجنماعية وطية ونيعية.

- ويبدو أن لدي أنصسار هذا الاتجاه خلط ما بين القوميــة و الجنســية

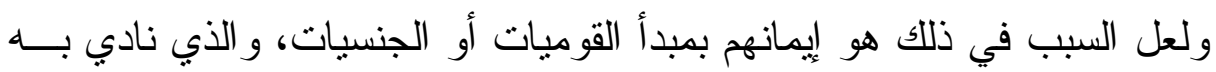

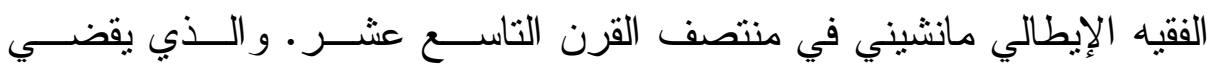

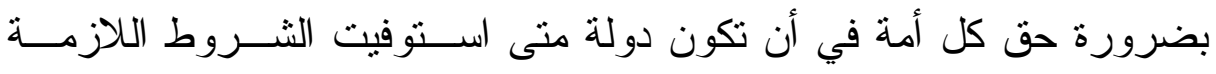

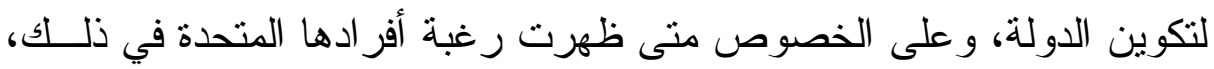

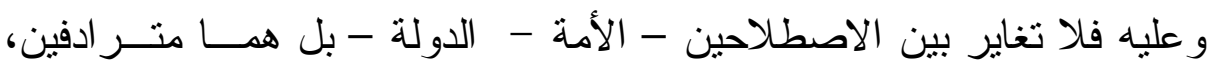
ويوجد تطابق بين الأمة و الدولة عند تحديد الأفر اد المكونين لأيهما.

ومهما يكن من أمر فإننا نتفق مع غيرنا في أنه يجب ألا نجاري هــــا

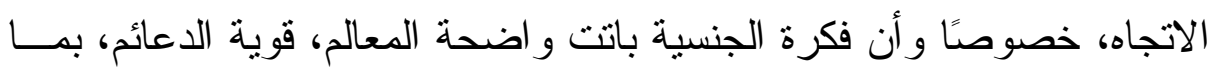

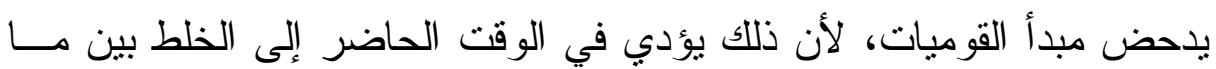
هو كائن وبين ما يجب أن يكون ('). لونيان

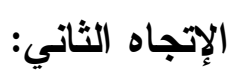

ذهب أنصـار هذا الاتجاه إلى أن الجنسية ما هي إلا رابطة بين الفــرد

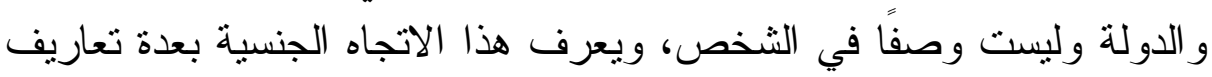
منها:

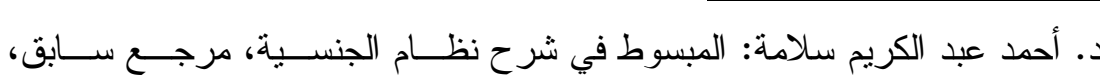

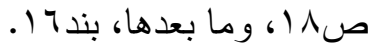




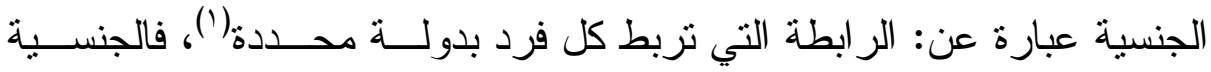

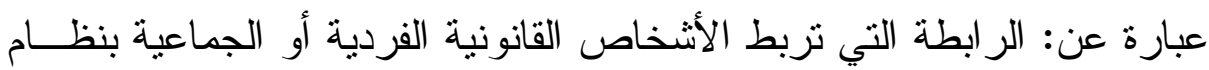

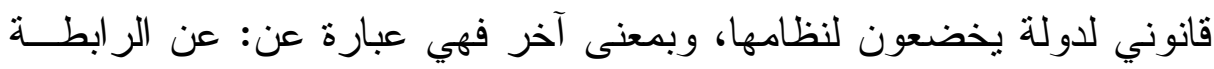
التي تصل الفرد بدولة، إلى حد جعله منتميًا إليها، و عنصرًا أساسيا فيها.

تقدير هذا الاتجاه: - ت

\section{يؤخذ على هذا الاتحاه عدة مآخذ منها:}

1 - هذا الاتجاه يكتفي بذكر أن الجنسية رابطة بين الفرد و الدولة، دون أن

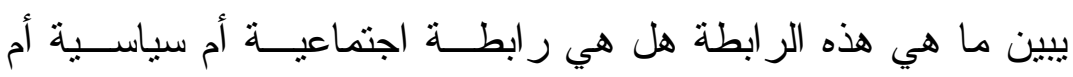

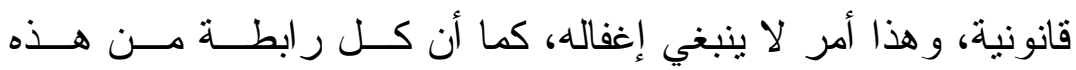
الرو ابط لا يخفي دور ها في مادة الجنسية.

r- - هذا الاتجاه بنطوي على مصادره المطلوب، فهو يعرف الجنسية عن

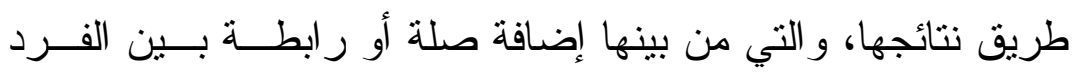

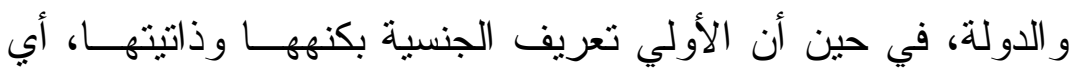

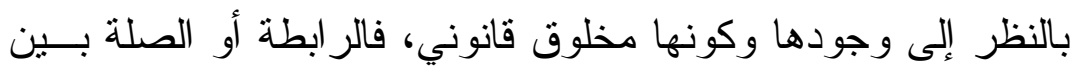

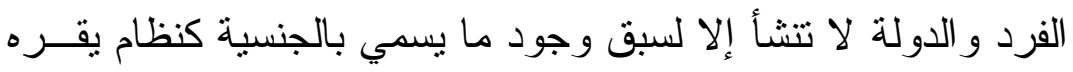
ويعترف به علم القانون عمومًا.

r- تعريف الجنسية بأنها رابطة، فضـلا عن الجدل بــين أنصــار هــــا

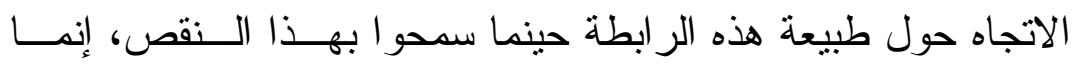

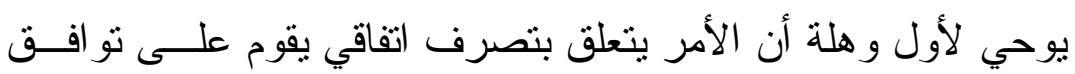

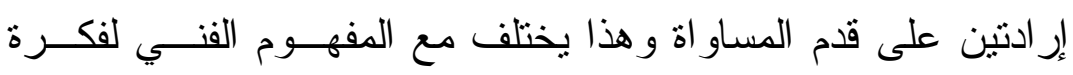

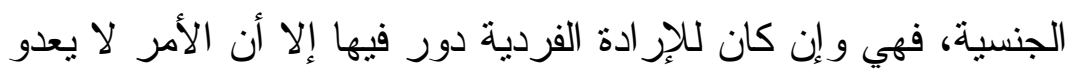

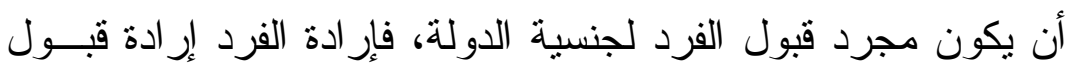

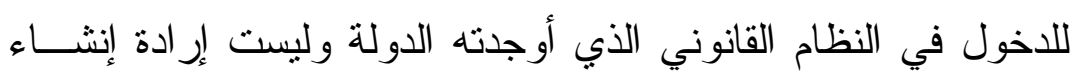
ذلك النظام.

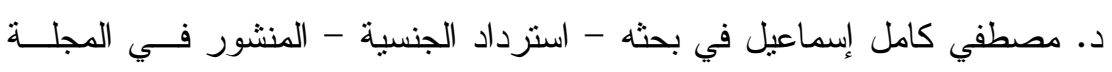

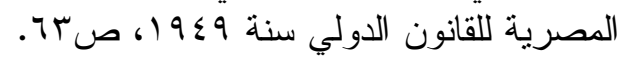


هذا الاتجاه يركز على الجانب السياسي في رابطة الجنسـية ويعـرف الجنسية بعدة تعاريف منها:

1 - الجنسية عبارة عن: الر ابطة السياسية التي تربط الفرد بدولة معينة.

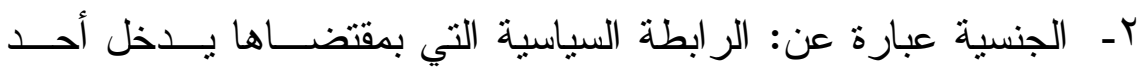

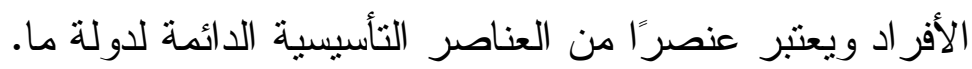
تقدير هذا الاتجاه:

يمتاز هذا الاتجاه بأنه أظهر الجانب السياسي في رابطة الجنسية، كمـــا

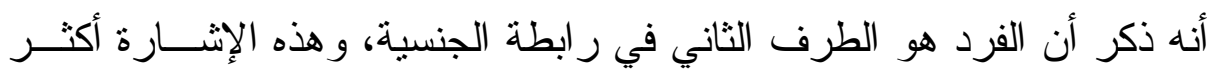

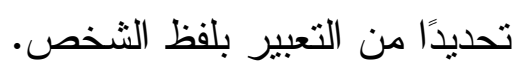

\section{ورغم ذلك فِانه يؤخذ عليه عدة مآخذ منها:}

1 - هذا الاتجاه قد أغفل النص على كل من الجانب الاجتماعي و القانوني

في رابطة الجنسية، و لا يخفي أن لكل منها دورًا في مادة الجنسية.

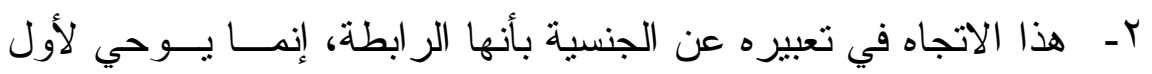

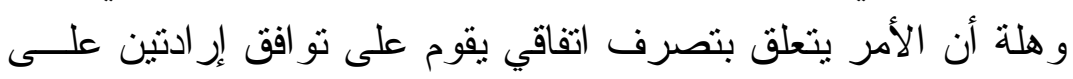

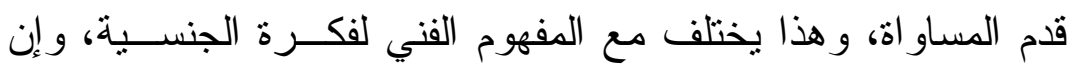

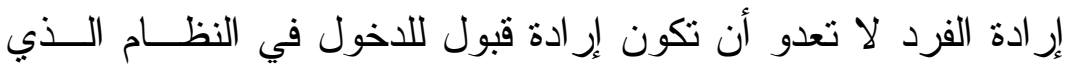

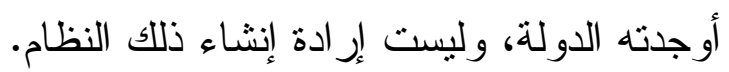

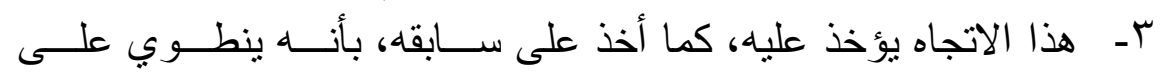

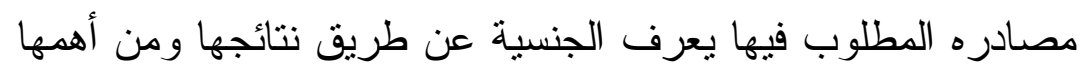

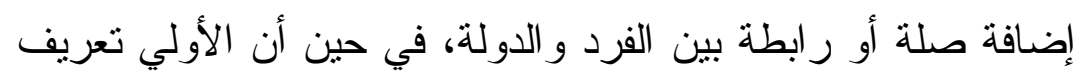

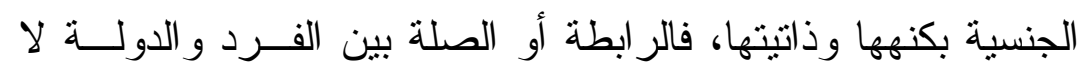

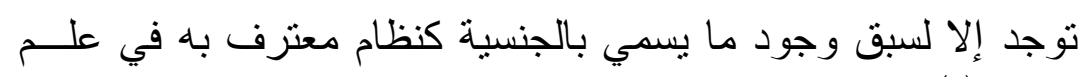

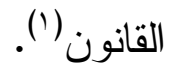

د. أحمد عبد الكريم سلامة: في مؤلفه، المبسوط في شرح نظام الجنسـية، مرجـع

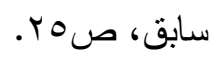

= إطلالة على الجنسية في الفقه الإسلامي والقانون الدولي الخاص 


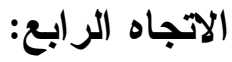

هذا الاتجاه يركز على الجانب القانوني في رابطة الجنسـية ويعـرف الجنسية بعدة تعاريف منها:

1 - الجنسية عبارة عن: علاقة قانونية بين الفرد و الدولة ويصبر الفــرد

$$
\text { بمقتضاها عضوًا في شعب الدولة عنة ('). }
$$

r- الجنسية عبارة عـن: الر ابطة القانونية التي تربط الإنسان بدولة ذات

$$
\text { سيادة يعتبر قانونا رعية لها. }
$$

r-ـ الجنسية عبارة عن: تبعية الثخص قانونا للسكان المكونين للدولة. عـ - الجنسية عبارة عن: الانتماء القانوني لشخص إلى الثــعب المكــون للدولة.

๑ـ ـ وفي المعني القانوني فإن الجنسية ما هي إلا تعبير قانوني للو اقع وأن الفرد متصل بشكل دقيق بسكان دولة معينة.

T- ـ و الجنسية هي إنتماء الثخص قانونًا للسكان المنشــئين - المكـــنين -

$$
\text { للدولة. }
$$

V- ما ذهبت إليه محكمة العدل الدولية في حكمها الصادر في 7 أبريـلـ سنة 1900 و هي بصدد نظر قضية - نوبتام - حيث عرفت الجنسية

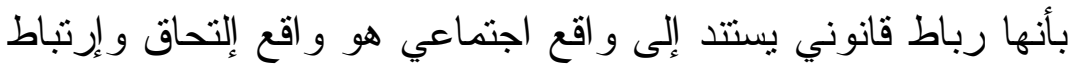

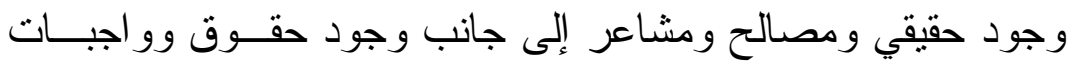

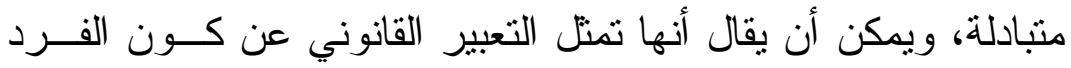

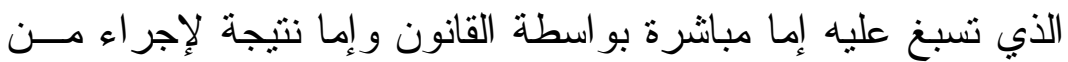

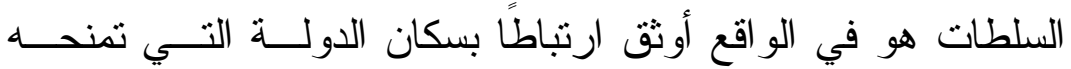

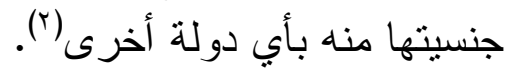

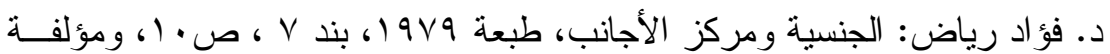

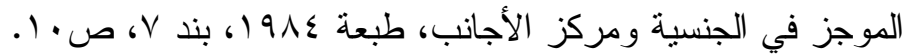

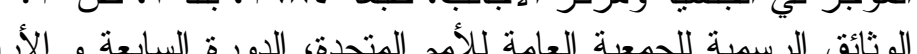

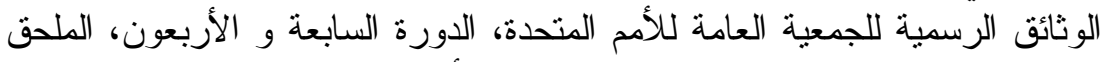

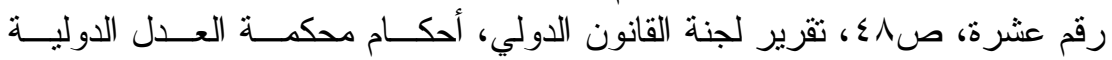

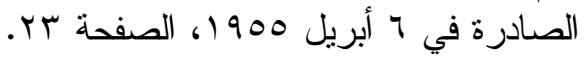


يتميز هذا الاتجاه بأنه أبرز الجانب القانوني في رابطـــة الجنســية إلا

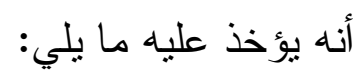

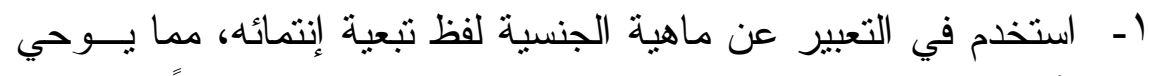

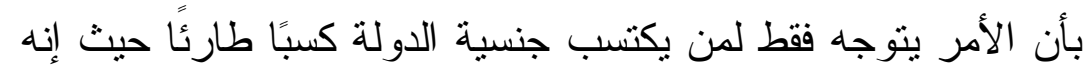

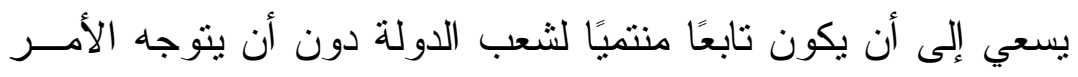

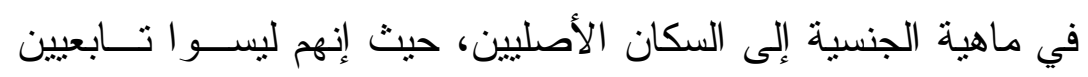
للدولة، بل هم منشئوها ومصدر سلة الطاتها.

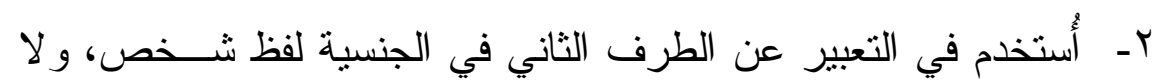

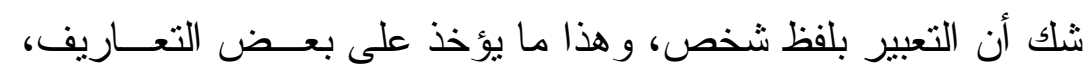
ويحمد للبعض الأخر أنه غير بلفظ الفرد.

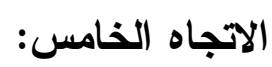

هذا الاتجاه يركز على كل من الجانب السياسي و القانوني في رابطة الجنسية

$$
\text { ويعرف الجنسية بعدة تعاريف منها: }
$$

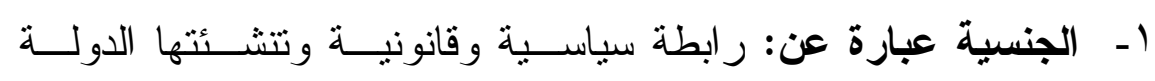

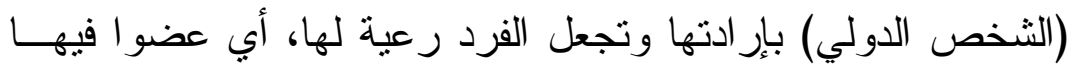

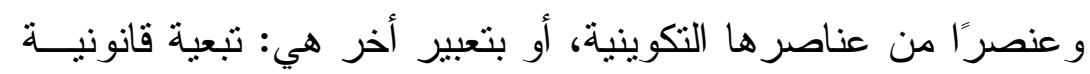

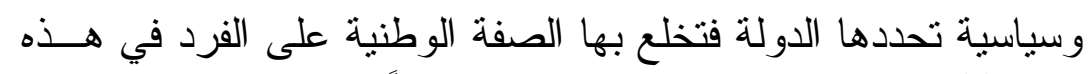

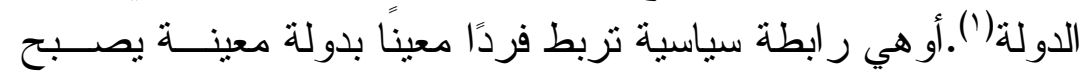

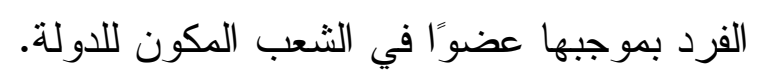

r- الجنسية هي: إقر ار سياسي وقانوني من الدولة بارنباط مجمو عة مــن الأفر اد بها، بصلات اجتماعية معينة تؤهلهم للانتماء لاء إليها.

r- الجنسية عبارة عن: صفة في الثخص ثقوم علــى رابطــة سياســية وقانونية بينه وبين دولة هو عنصة عن من فن عناصر ها التكوينية.

د. على الزيني: القانون الدولي الخاص المصري و المقارن، سنة 941 19، مطبعـة

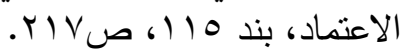


عـ - الجنسية عبارة عن: صفة في الثخص تقوم علـى رابطـــة سياســية

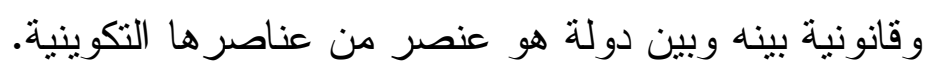

هـ - ما ذهب إليه الفقه و القضاء المصريين، حيث إنه يمكن القول بأن هذا

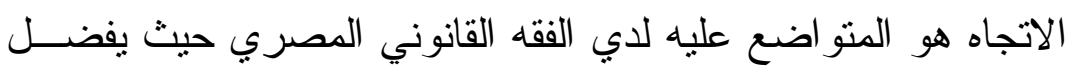

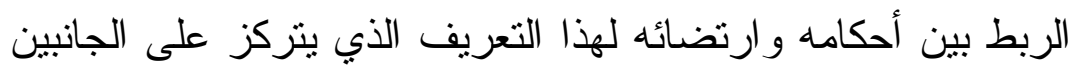

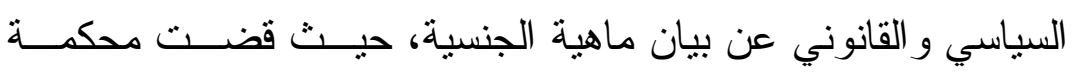
القضاء الإداري في العديد من أحكامها أن الجنسية كما عرفها رجانية الجنال الفقه هي "العلاقة السياسية و القانونية التي نزبط الفرد بلديد بدولة ما...". - كما أخذت بذلك المحكمة الإدارية العليا في العديد من أحكامها حيــث

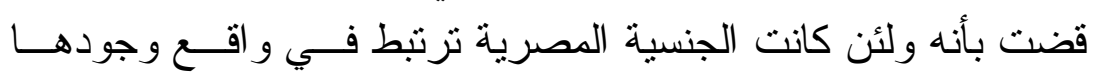

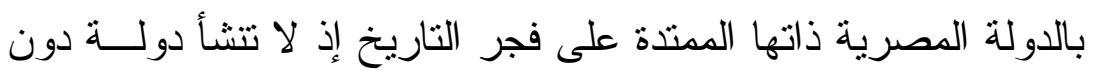

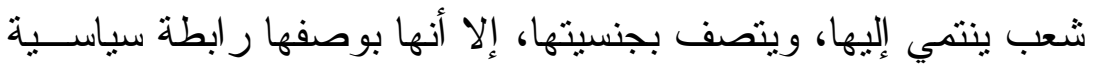
وقانونية وبين فرد ودولة ظلت غير محدودة المعالم من الوجهة الدولية إلى أن صدرت التشريعات التي تنظمها.

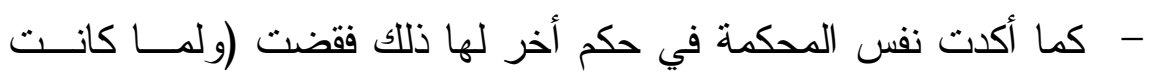

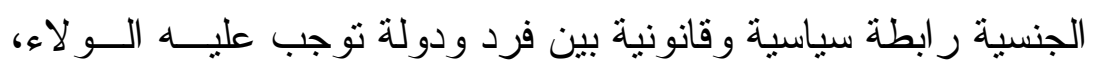

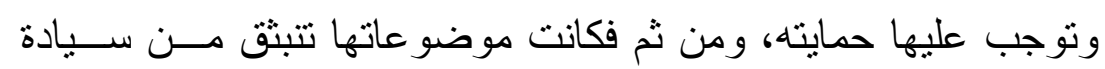

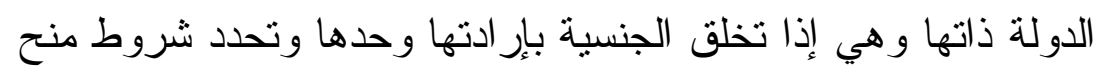

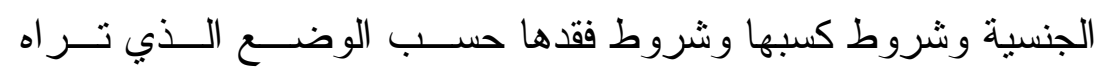

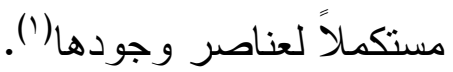

تقدير هذا الاتجاه:

ما يميز هذا الإتجاه أنه يبرز خاصيتين أساســـيتين مــن خصــائص رابطـــة

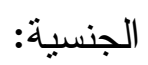

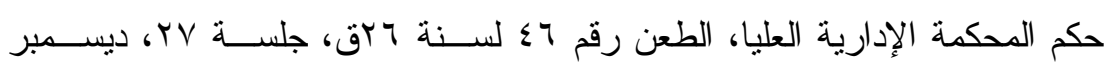

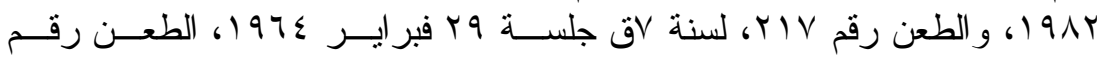

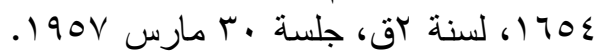


الخاصية السياسية: والتي تعبر عن مدي سلطة الدولة في تتظيم مادة الجنسية

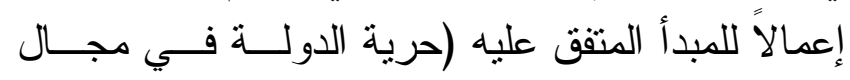

$$
\text { (الجنسية). }
$$

الخاصية القاتونية: و التي تعبر عن الآثار القانونية التي تترتــب علــى قيــام

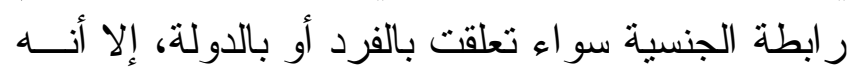

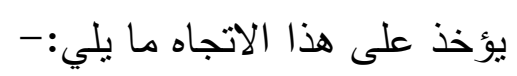

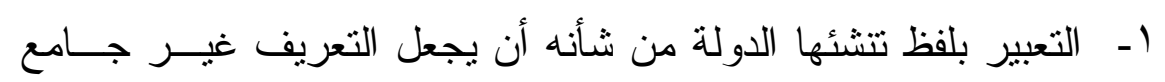

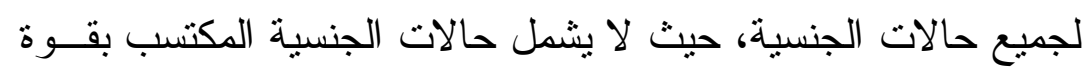

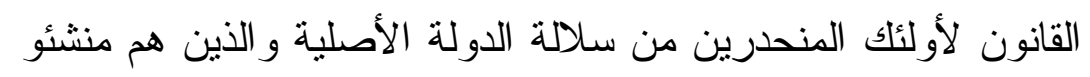

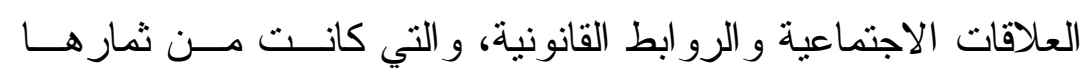

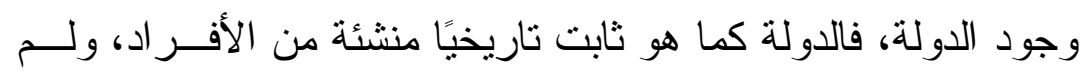

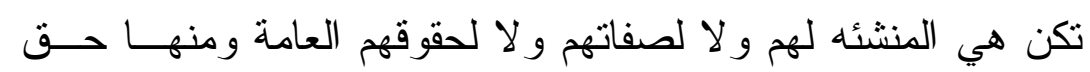

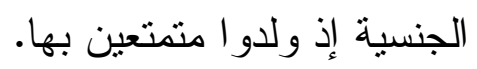

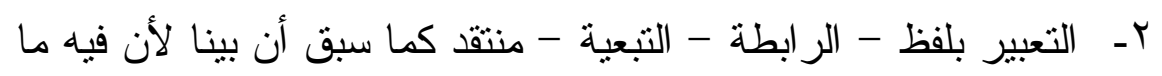

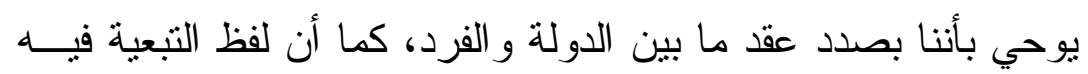

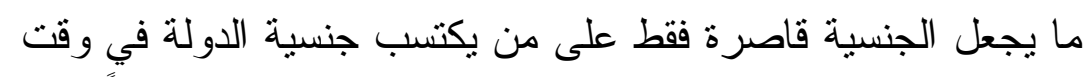

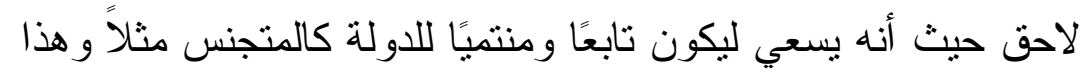
أمر غير صحيح كما بينا.

\section{الإطالب الثاني}

\section{ماهية الاختلاف بين الجنسية والقومية}

فالجنسية تعبر عن انتماء الفرد إلى دولة، والدولة تقوم "علــى أركــان

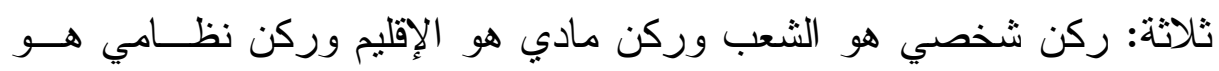

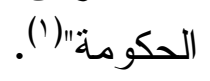

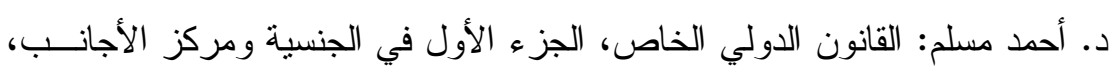

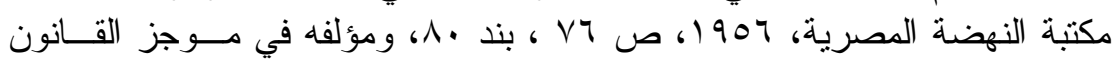

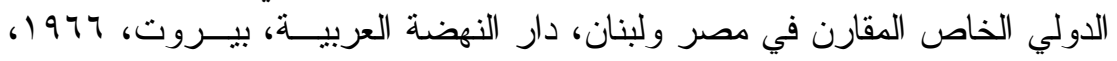
ص الاولي الخصاص 


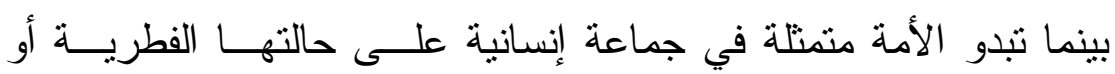

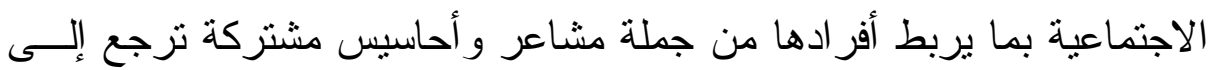

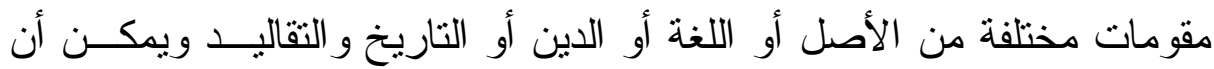
يطلق على هذه الأمور جميعاً، العوامل الموضوعية، يضاف إليها عامل هــام

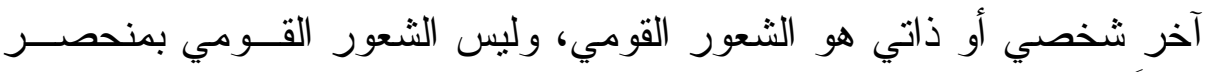

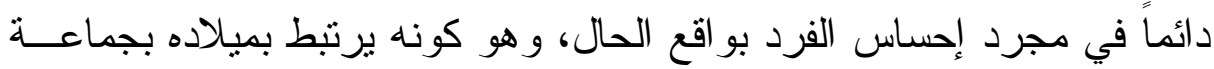

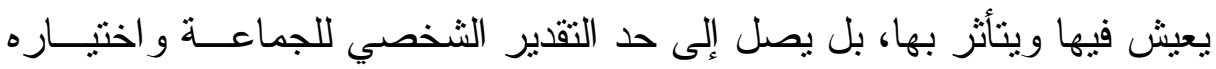

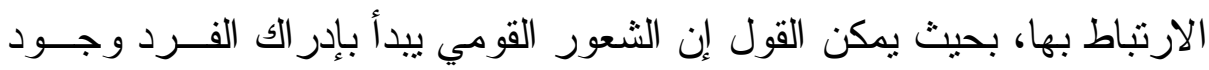

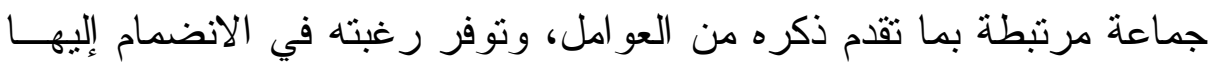

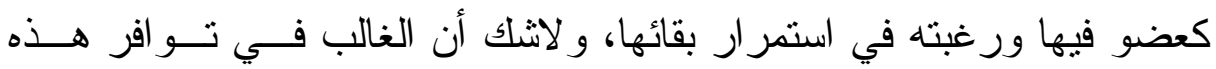

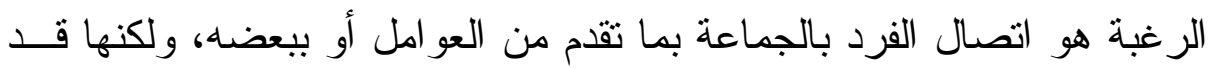

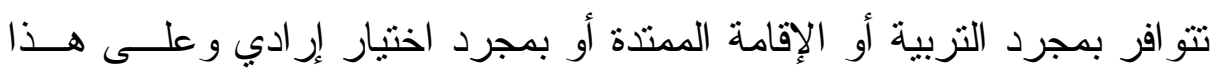
الوجه يتم تكوين وحدة اجتماعية هامة هي الأمة.

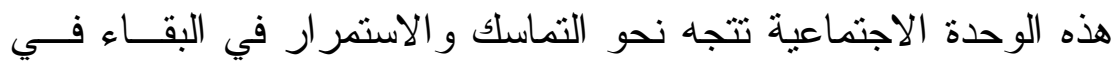

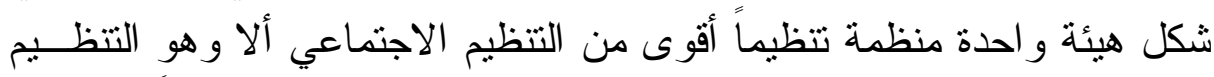

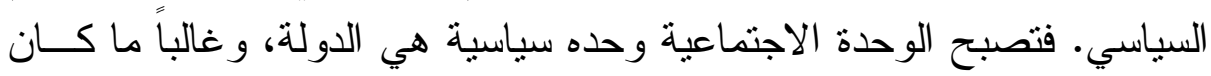

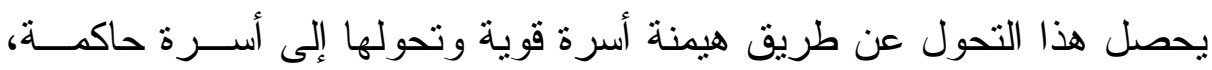

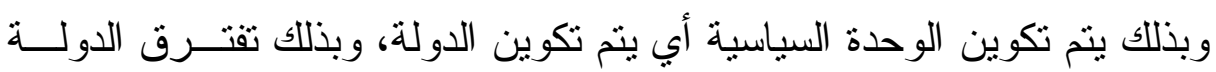

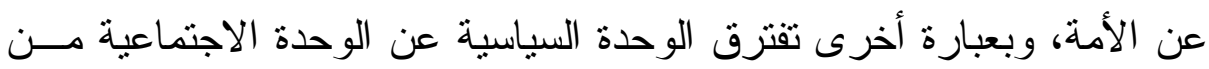

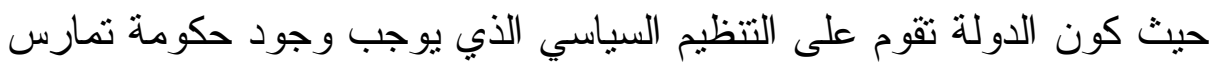
سلطة على إقليم معين و على سكانه.

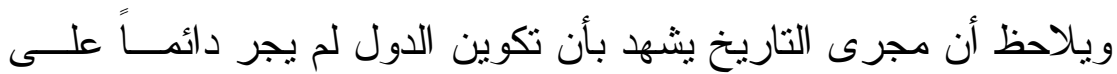

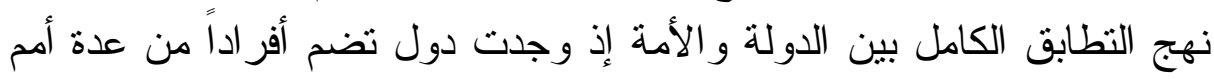
أو العكس وجدت أمة و احدة وتتكون من عدة دول.

ولما اندلعت الثورة الفرنسية ألهبت الأذهان بالكثير من الأفكـار التـي

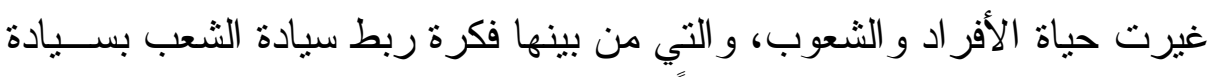

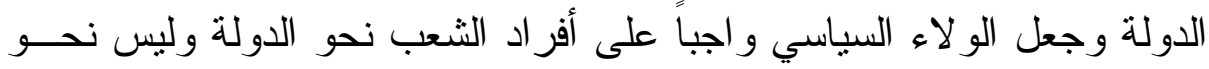


شخص رئيسها ومن بين تللك الأفكار أيضاً فكرة حق كل شــعب فــي تقريــر

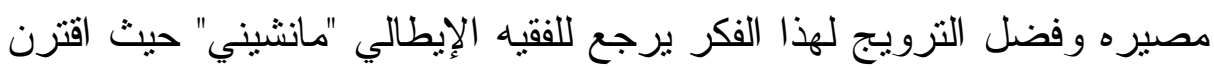

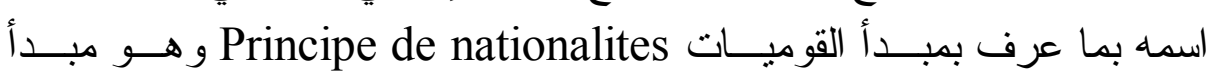
سياسي رتب عليه نتيجة قانونية تتعلق بالقانون الدولي العام وهي حق كل أمسـة

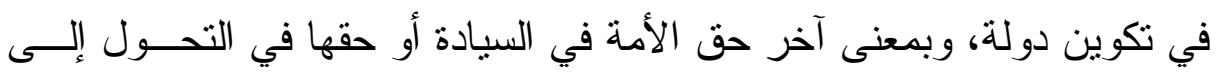

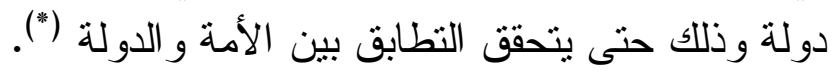

ويترتب على هذا التطابق اندماج الثعور بالقوميــة Le nationalisme

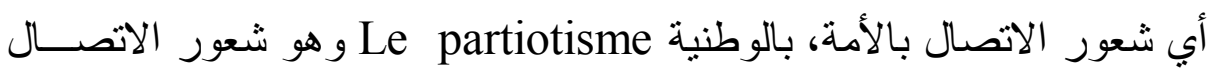
بالدولة أي الثعور الوطني (') ومبدأ القوميات كان له أعمق الأثر في تكوين وتطور كثير من الحركات

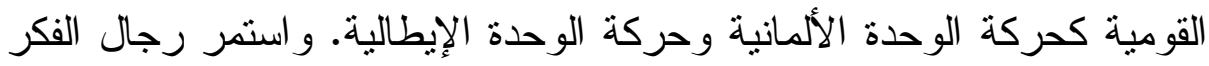

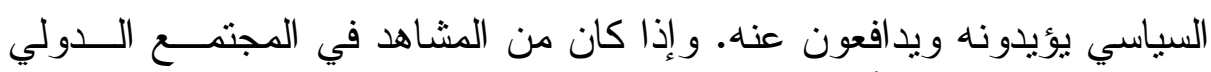

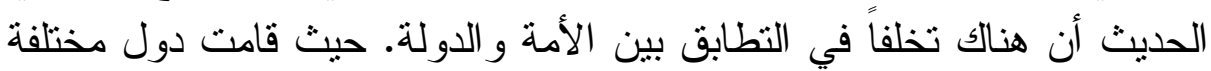

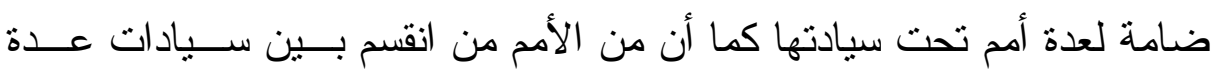

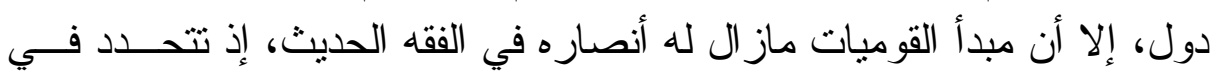

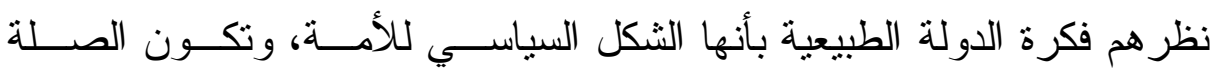

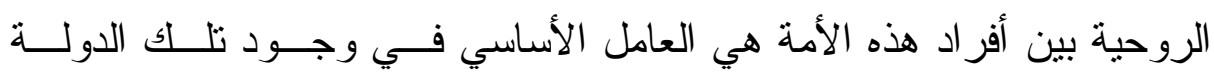
و وازدهار ها.

و على هذا الأساس يمكن فهم تقسيم بعض الفقه للجنسية بين ما أســـمَوْه

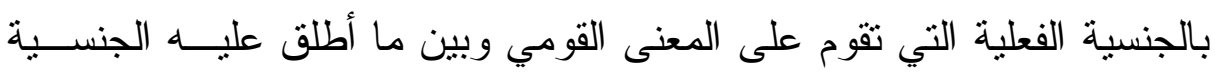

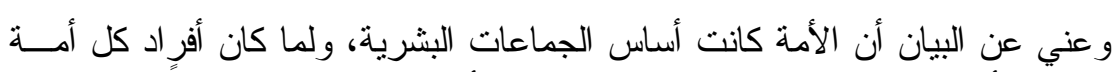

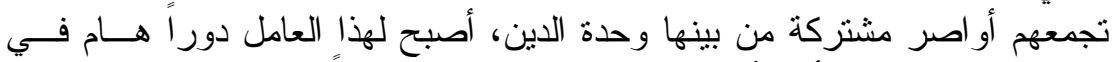

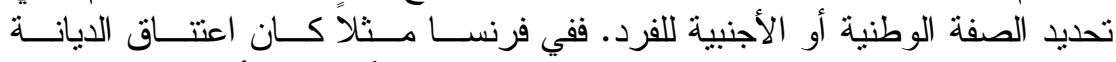

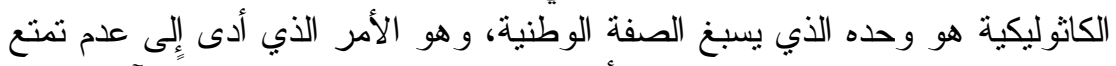

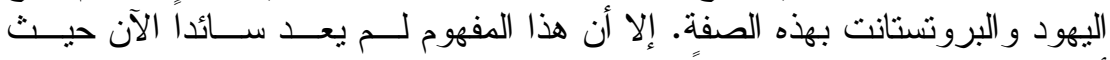

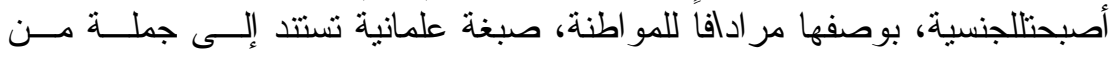

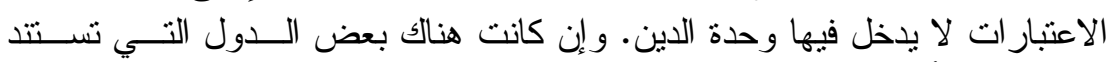
جنسيتها إلى أساس ديني مثل إسر ائيل، للمزيد ير إن إنع: http://www.startimes.con/?t=139247795

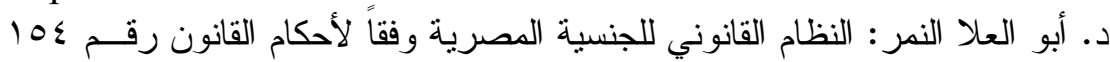

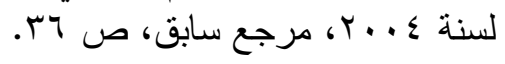


القانونية التي تقوم على الارتباط بالدولة، جاعلين من الربط بين النوعين مــن

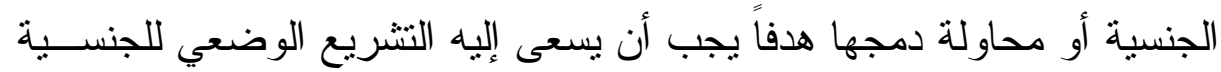

وقد استمر مبدأ القوميات ولا يز ال هذا المبدأ مستقرًا في الفكر السياسي

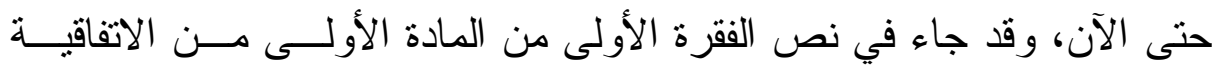

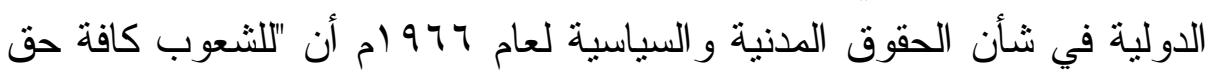

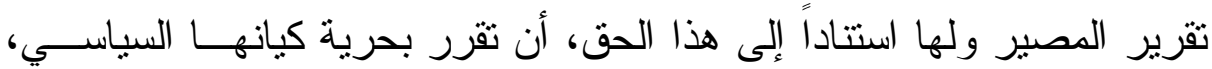

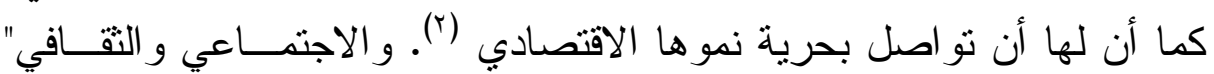

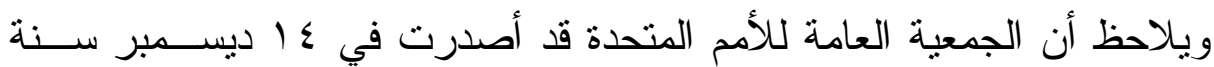

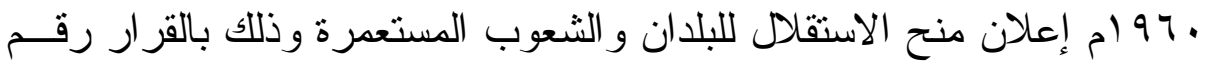

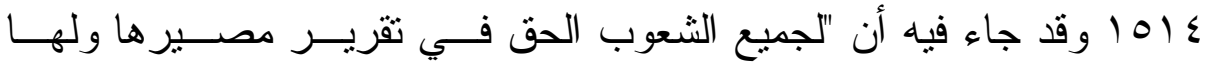

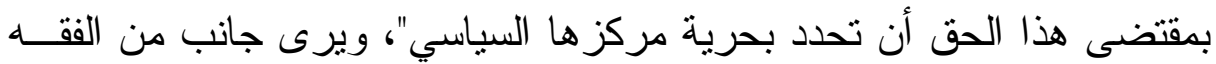

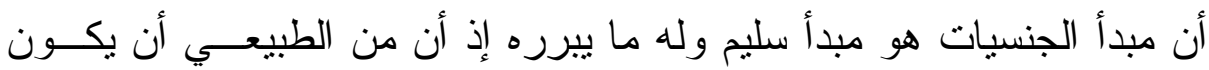

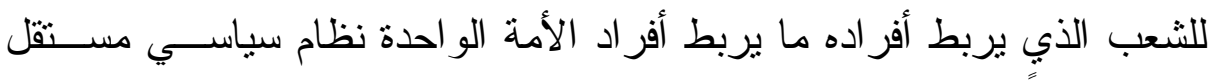

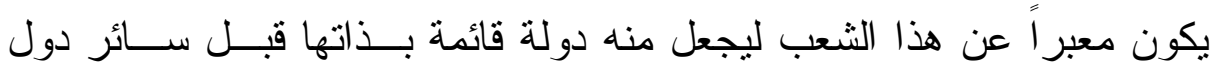

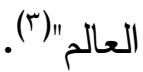

- و الخلاصة أن الفارق بين الجنسية و القومية بتخذ مظاهر مختلفة تتمتل

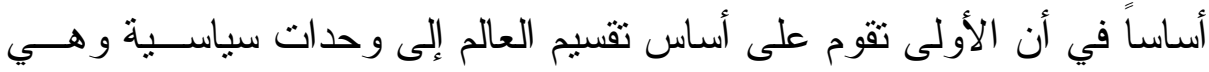
الدول في حين أن القومية تقوم على تقيم العالم إلى وحدات اجتماعية وهـيـي الأمم.

- و الجنسية تعد حالة قانونية تتقرر بمقتضى تشريع تصـــره الســلطة الحاكمة في كل دولة بما لها من سيادة في تحديد عنصر السكان فيها ومن هذا

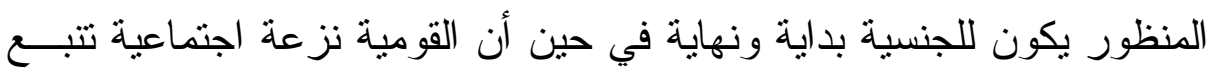

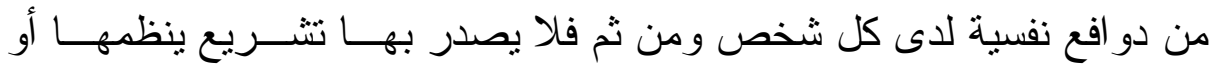

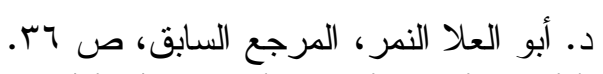

( $\left.{ }^{2}\right) \quad$ http://www.ommahconf.com/site/news.php?action=view\&id=95.

د. إير اهيم أحمد إبر اهيم: "القانون الدولي الخاص"، الجزء الأول، الجنسية ومركــز

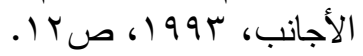


يحكمها و عليه فليس للقومية بداية كما أنها لا تشقط عن الثخص أي ليس لهــا نهاية.

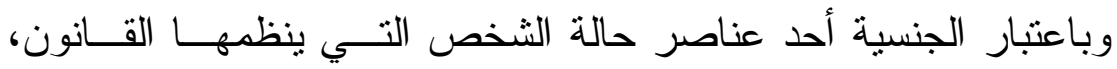

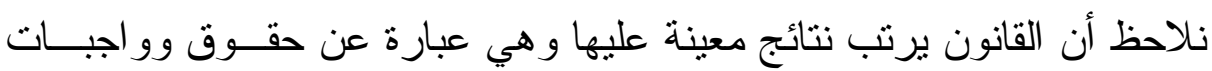

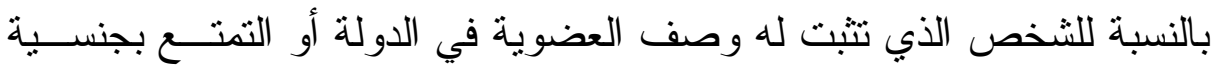

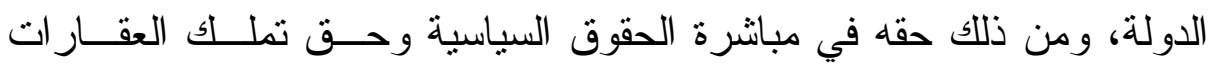

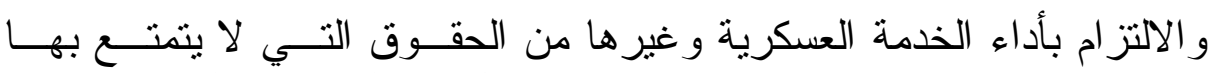

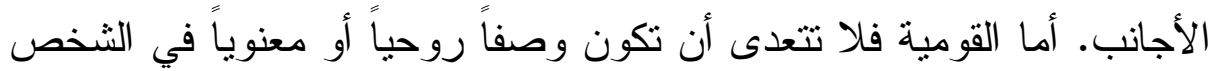
وليست لها آثار قانونية منل التي تترتب ملت على الجنسية.

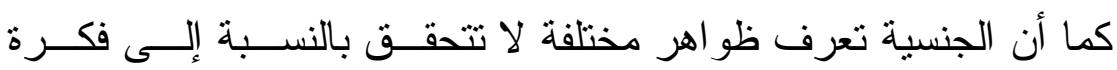

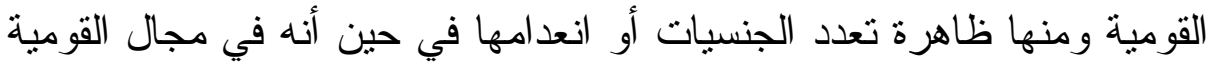

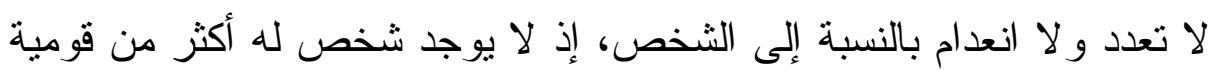
و لا شخص عديم القومية (').

\section{المبمث الثالث}

نظرة على جوانب المواطنة والجنسية في الفقه الإسلامي والقانون الدولي الغاص

:تمهيـــ

ليس ثمّة عنو ان لظاهرة الجنسية في الفقه الإسلامي، ولذلك توجد - أو

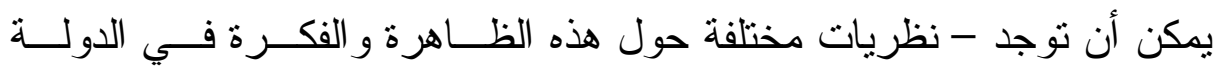
الإسلامية، أو في الفقه الإسلامي.

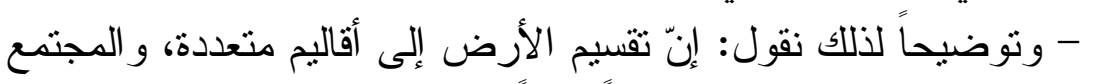

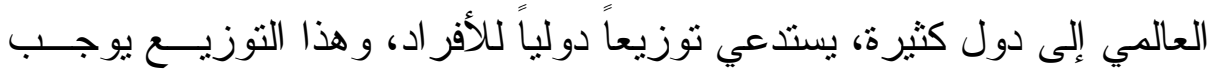

د. أحمد قسمت الجداوي: القانون الدولي الخاص، ص • • ؟، بند 0ء، د. عز الدين

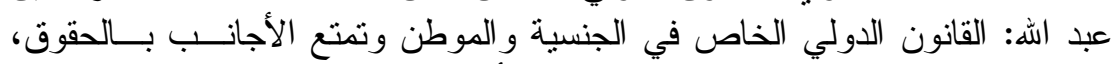

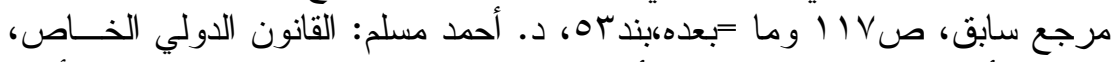

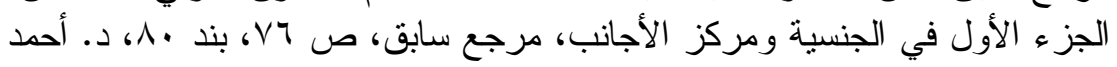

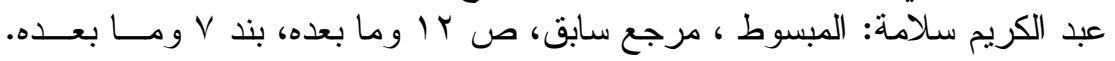


ظهور فكرة الجنسية التي على ضوئها تتمكن الدول من تعيين أعضاء شعوبها،

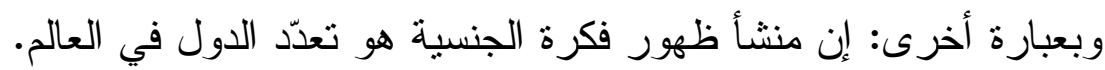

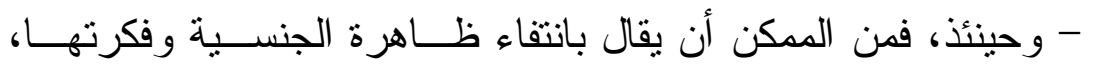

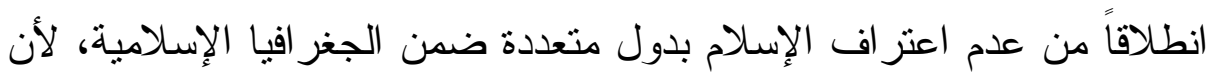

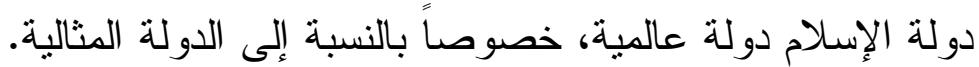

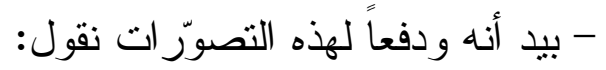

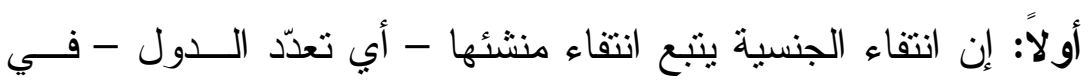

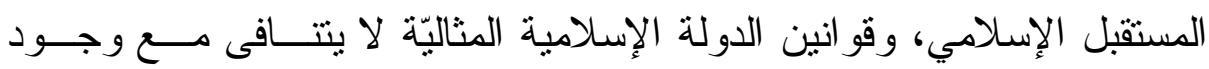

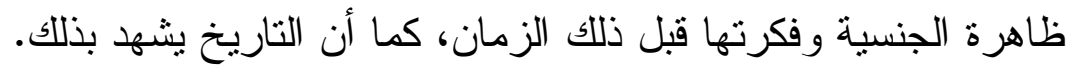

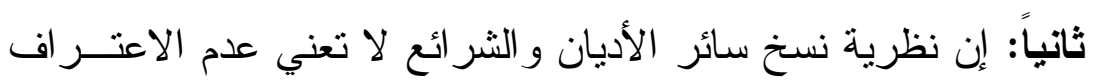

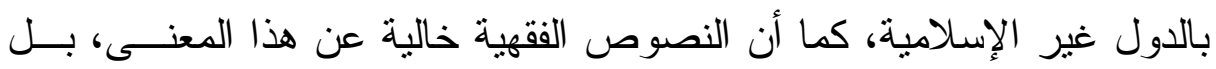

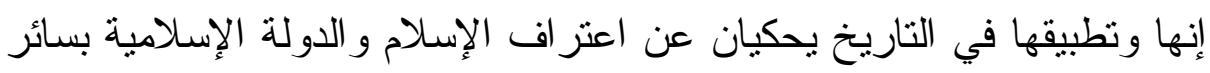

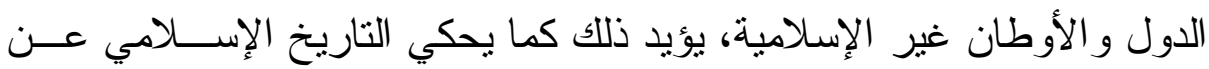

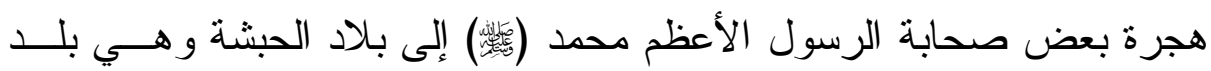
غير إسلامي آنذالك وملكها كان غير مسلم. لونول.

ثالثـاً: إن عدم انطباق قو انين الجنسية الإسلامية و أسسها على الجنسية

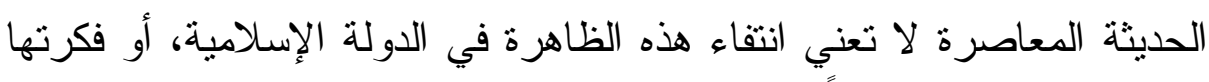

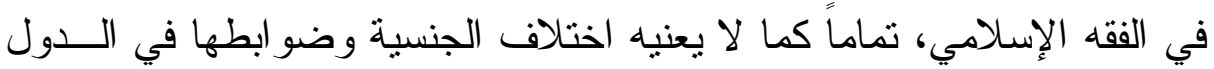
المختلفة في العالم الحاضر •

- لكن مع ذلك كله يرى أنّ إبطال نظرية انتفاء الجنسية في الإسلام لا يكفي لإثبات وجود فكرة الجنسية في الفقه الإسلامي، حتى في صورة الإقرار

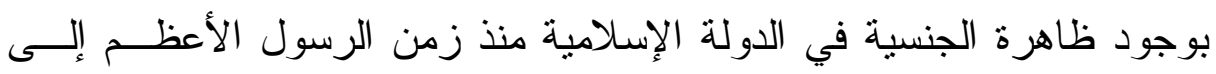
زماننا هذا عبر التاريخ؛ لأن وجود ظاهرة الجنسية في الدول الإسلامية كـــان نتيجة تعدد الدول في العالم الإسلامي لا بدعوة من الإسلام نفسه، ومن المان المدكن

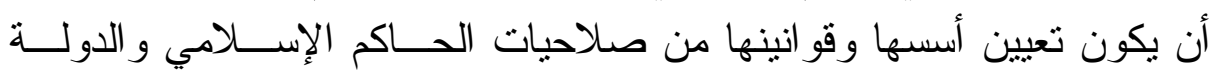
الإسلامية، لا الفقه الإسلامي. 


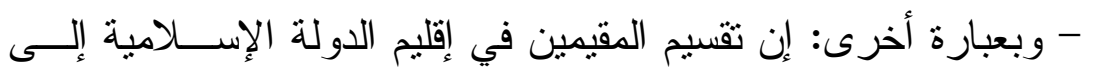

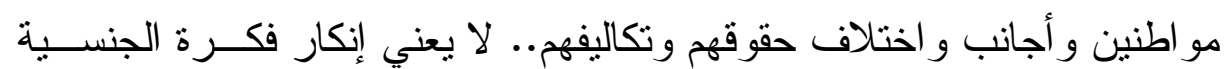

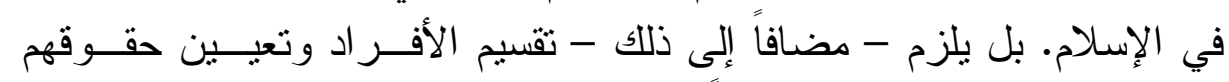
وتكاليفهم في الفقه الإسلامي أيضاً.

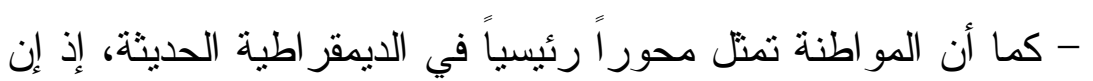

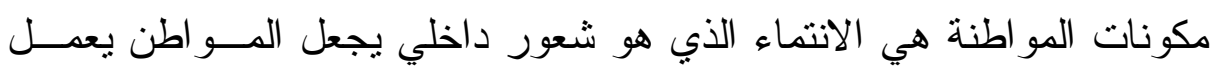

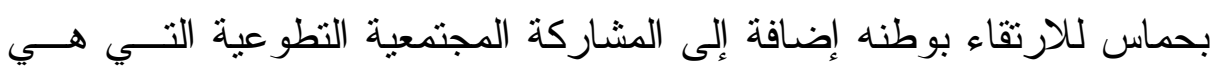

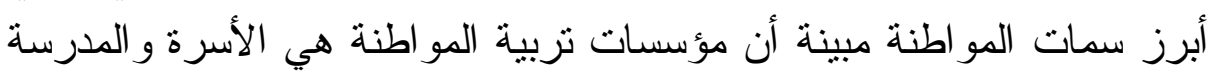

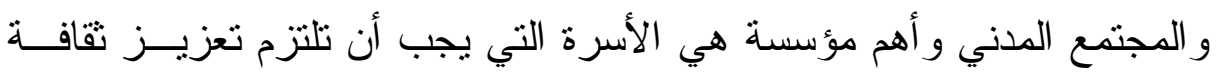

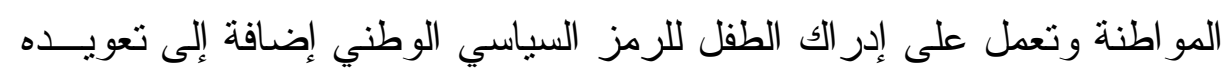
على احتر ام القانون وغرس حب إلب الوطن و الدفاع عنه بداخله ( ').

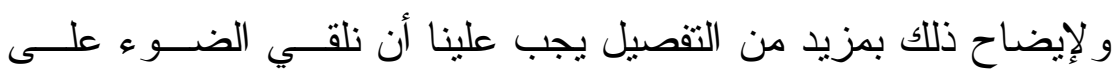

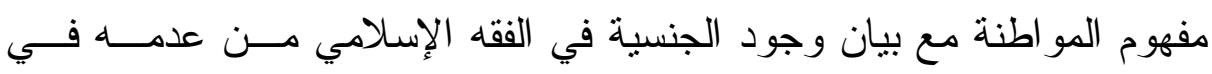
مطلبين وذللك على النحو التالي: مفو ولئ

\section{الإسب الأول}

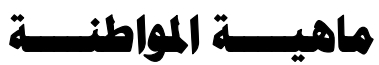

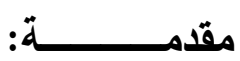

- لقد تكوّتت الأمة الإسلامية بعد الهجرة في المدينة المنورّة، وإن كان

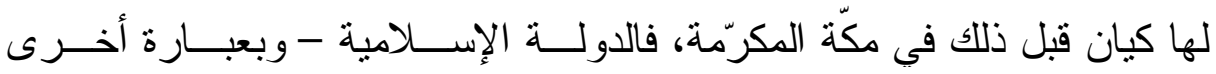

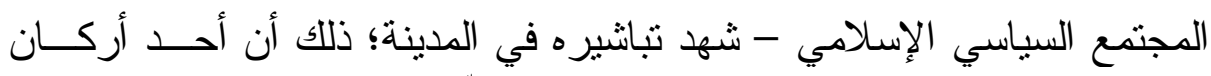

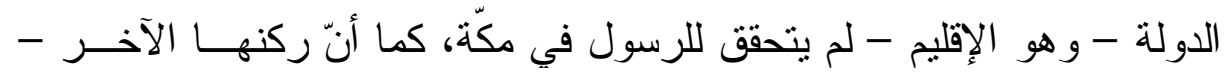

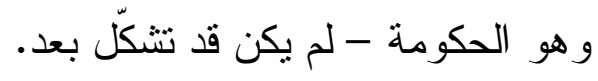

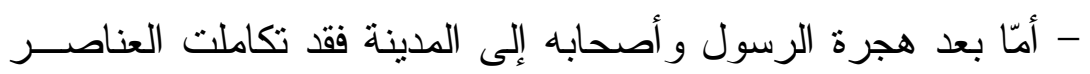

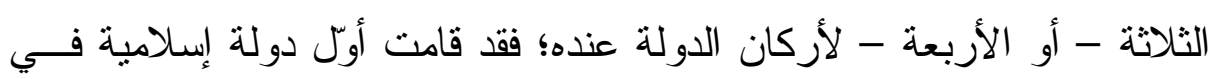

( ${ }^{1}$ http://www.almaaref.org/books/contentsimages/books/dirasat/alesla meyo un_walmocharaka/page/lesson3.htm. 
المدينة المنورة وكان المسلمون من المهاجرين و الأنصار ويهود المدينة الــذين التزمو ا بميثاق المدينة شعباً لها.

- وبعد استقرار الدولة النبوية في المدينة أنثدّ الناس نحـــو الإســلام

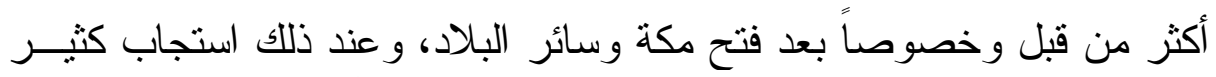

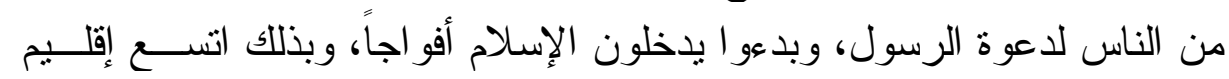

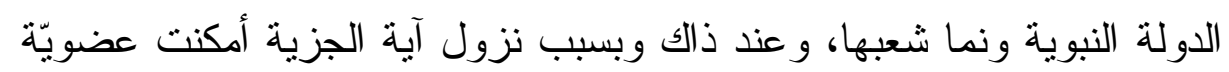

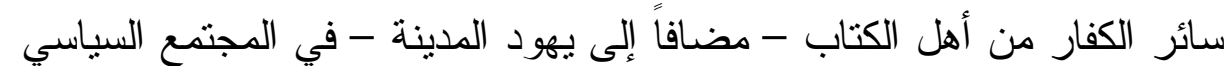

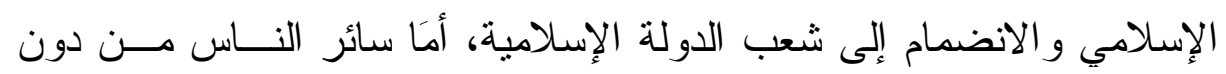

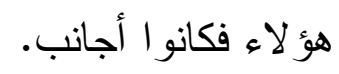

- على هذا، نرى أن معيار المو اطنة في المجتمع السياسي النبــوي -

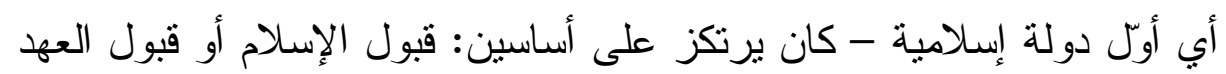

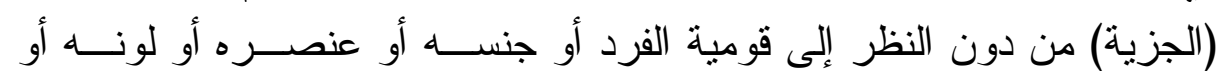

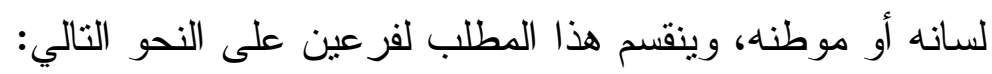




\section{الفرع الأول

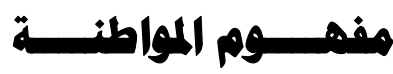

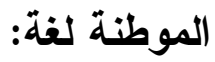

يقال "وطن بالمكان يطن وطناً أقام به" و"أوطن المكان وطن به و البلــــ

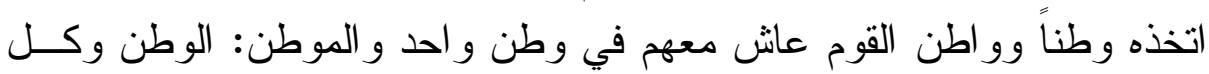

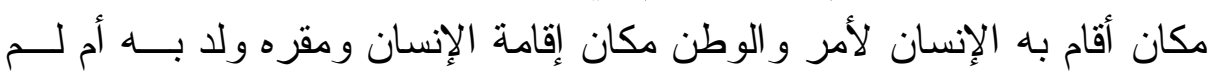

يولا (')

المو (طنة اصطلاحاً:

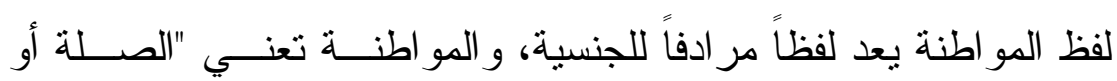

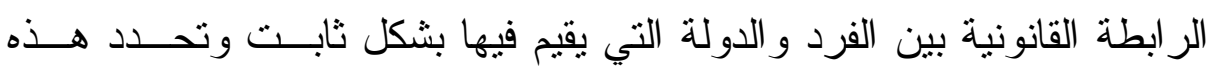

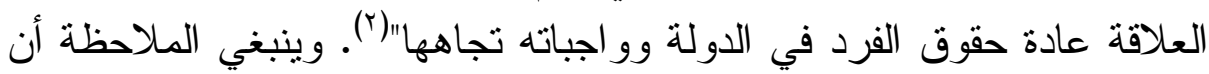
هذا التعريف ركز على الناحية القانونية وأغفل الحديث عن الناحية السياسئهـية.

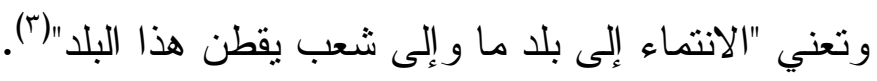

ويرى الباحث أن المو اطنة تعني: انتماء الفرد إلى الدولة التي ولد علـى إلى

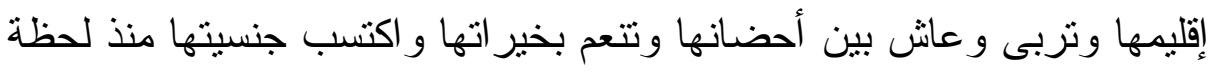

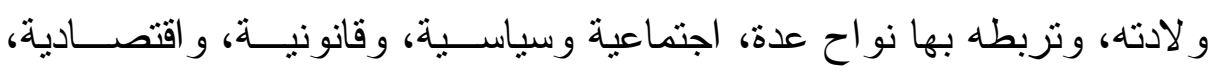

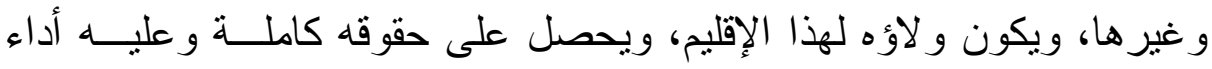

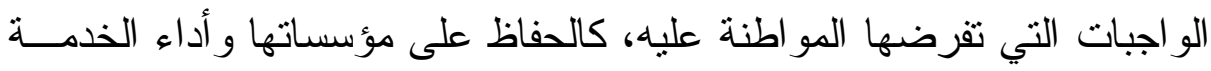

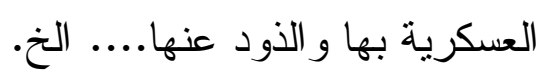

وهناك ألفاظ ذات صلة بلفظ المو اطنة لابد من الإشارة إليها وهي:

مجمع اللغة العربية: المعجم الوسيط، جr، ص ؟0. 1.

نبيل الصالح: ما هي المواطنة؟ سلسلة مبادئ الديمقر اطية (1)، الطبعـة الأولـى،

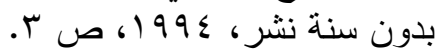

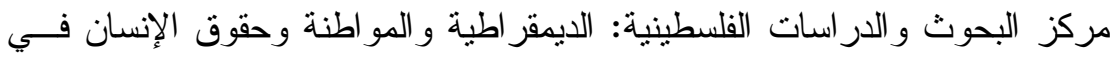
فلسطين، الطبعة الثانية، ـ99 199، ص الثرات 11. 
الوطن و هو "البلد الذي ولد المرء فيه أو البلد الذي ينسب المرء إليه من حيث جنسيته أي تابعيته". وهو "الأرض التي ينشأ عليها الإنسان ويتخذها مقراً

- وبعد بيان مفهوم الجنسية و المو اطنة يمكنني ملاحظة علاقــة تـــربط

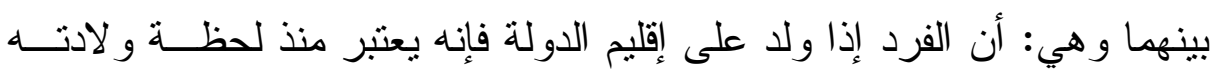

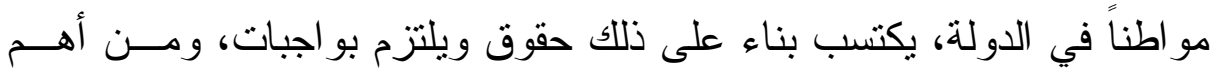

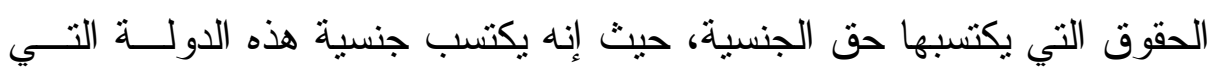

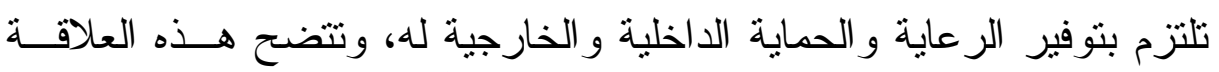

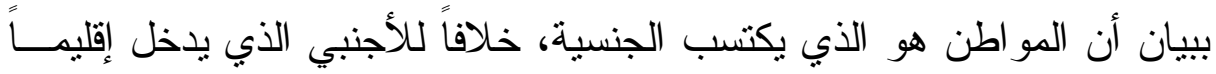

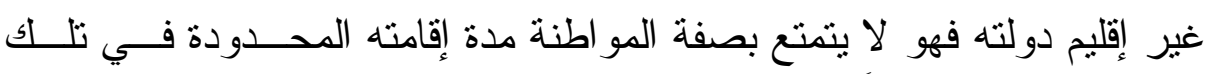

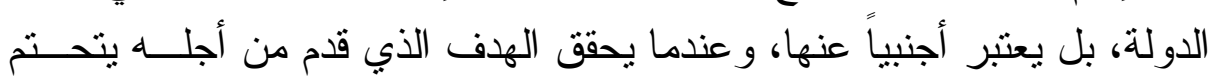
عليه الرحيل إلى بلده.

\section{الفرق بين المواطنة و الجنسية:}

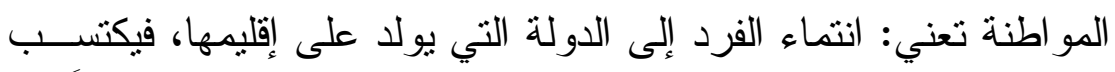

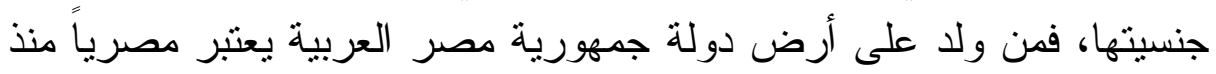

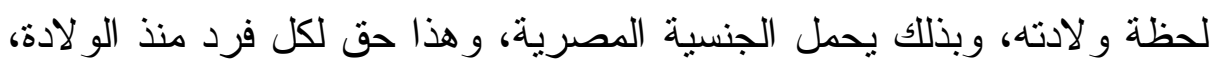

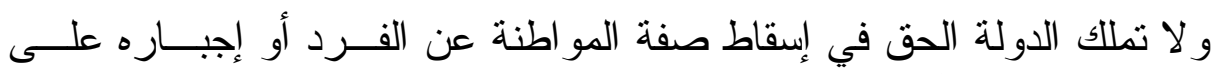

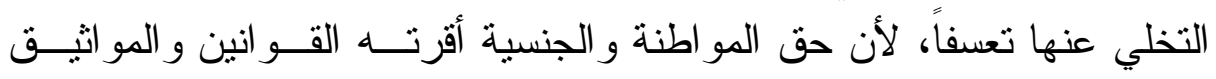

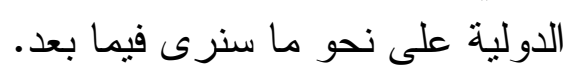

- و الفرد قد يكتسب الجنسية منذ لحظة و لادته على إقليم دولته، وتسمى التى

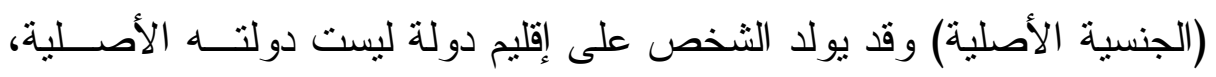

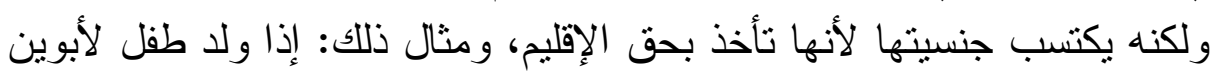

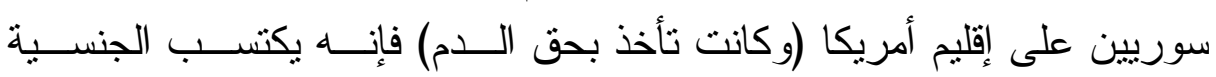

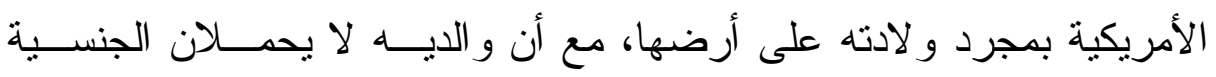

(') إبر اهيم ناصر : التربية المدنية (المو اطنة)، الطبعة الأولى، الأردن، عــان، ع99 19 ص إير اله اصن 


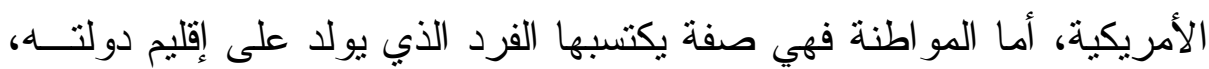
و آباؤه و أجداده يحملون جنسية ومو اطنة الدولة.

وقد يكتسب الفرد جنسية دولة غير دولته الأصلية في وقت لاحق للميلاد

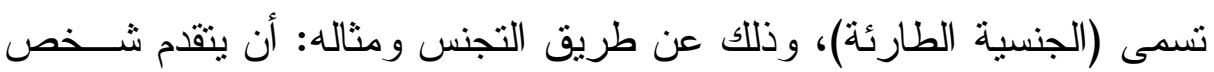

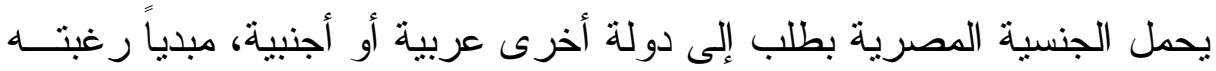

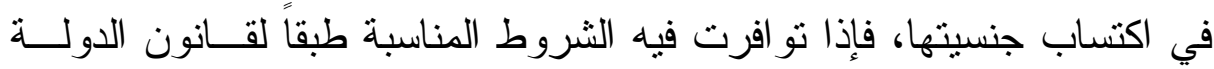

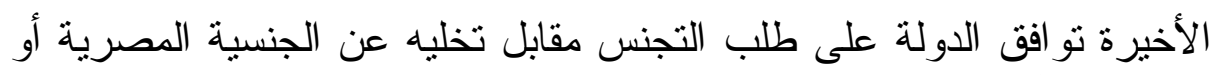

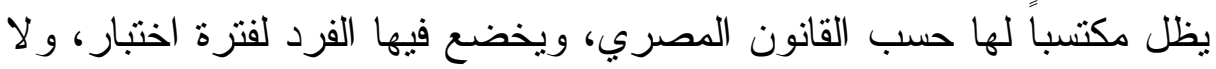
يعتبر كالمو اطن الأصلي فيها، فيحرم من بعض الوظائف و الحقــوق لاســـيما السياسية.

ويكتسب الشخص جنسية دولة غير دولته الأصلية عن طريق الــزواج

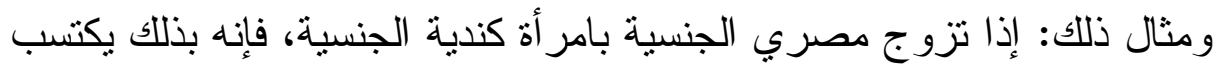

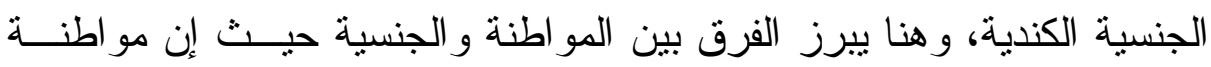

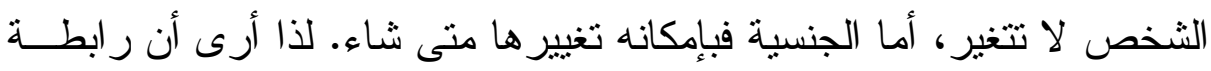

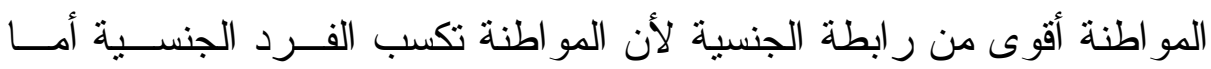
الجنسية فلا تكسبه صفة المو اطنة.

\section{أهمية المو (طنة:}

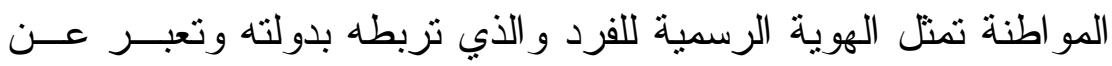

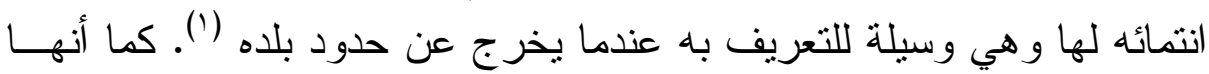

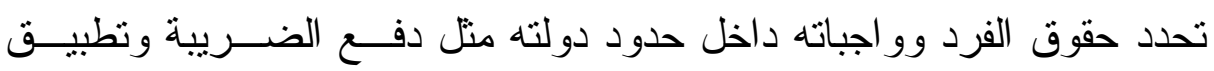

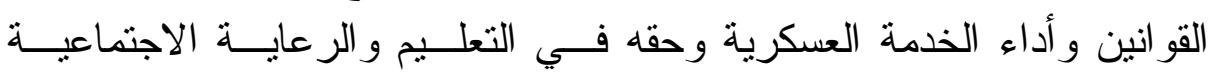

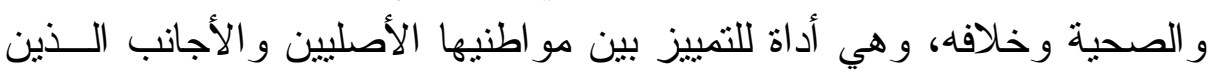


يحرمون من عدد من الحقوق السياسية وبعض الوظائف ('). وبعض الحقــوق المدنية ومنها حق التملك ذاته (؟)

و أخيرًا فللمو اطنة أهمية من الناحية النفسية، و الاجتماعية، و السياسية، إذ إذها

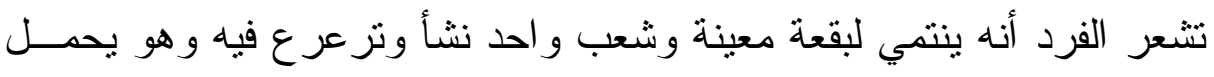

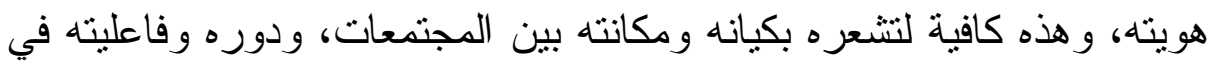

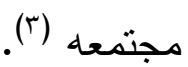

شبل بدران: التعليم و المو اطنة وحقوق الإنسان، الطبعة الأولــى، القـاهرة، الـــار

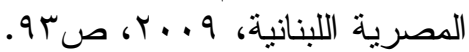

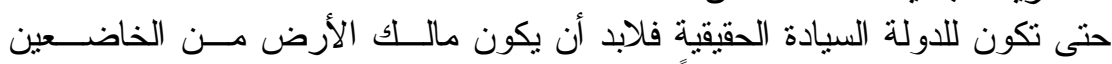

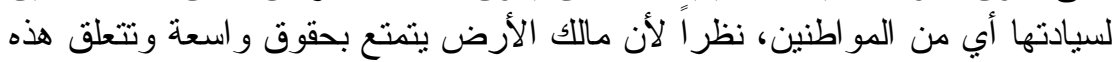

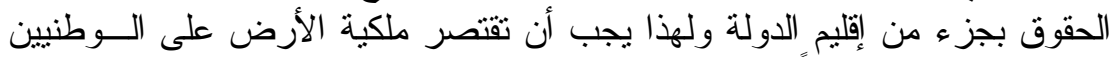

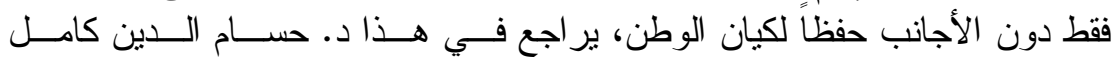

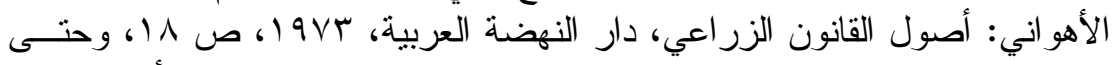

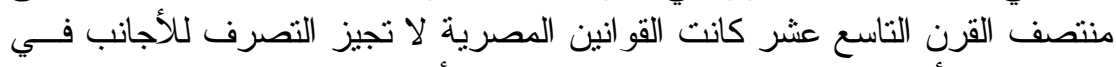

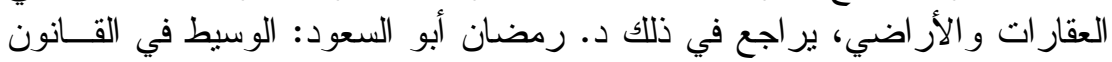

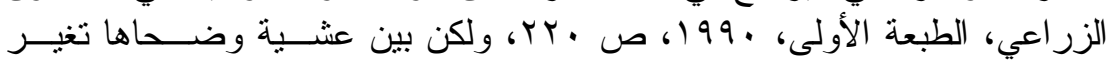

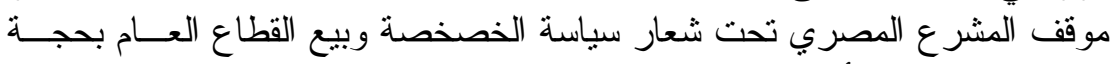

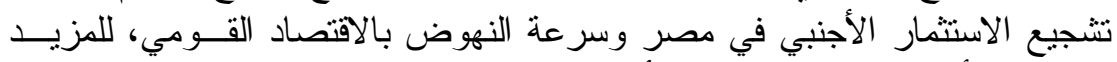

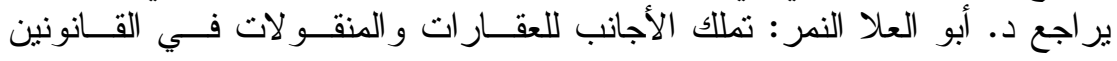

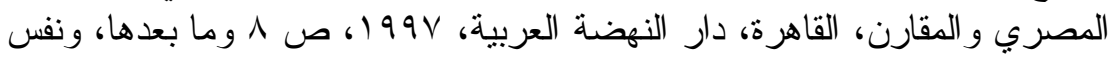

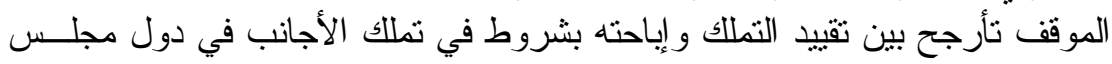

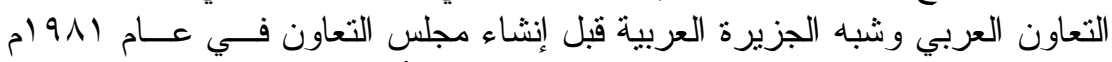

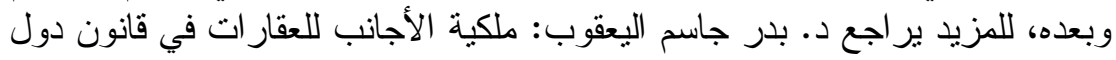

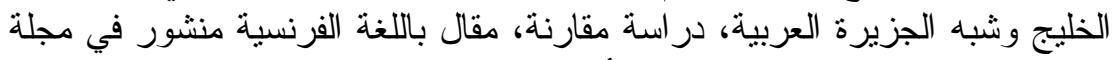

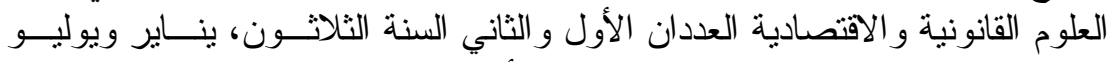

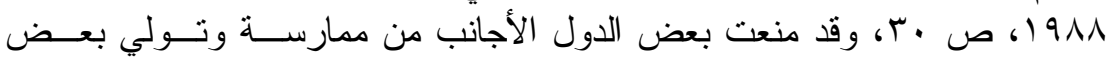

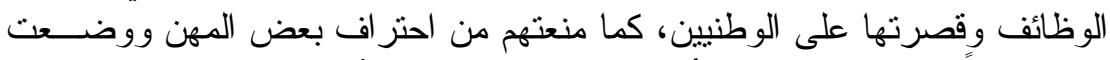

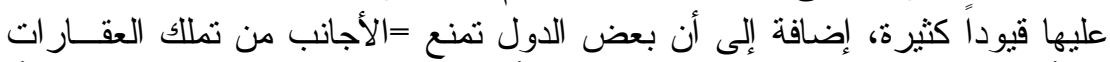

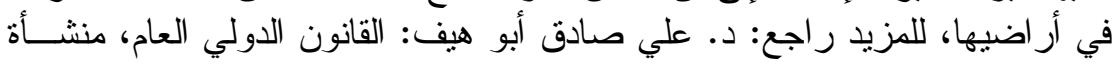

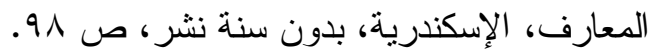

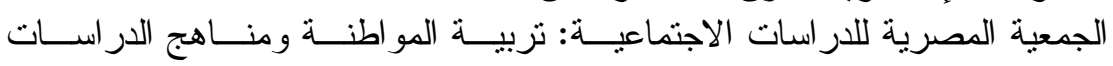

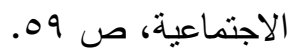




\section{الفرع الثماني \\ أسباب كسب المواطنة في الشريعة الإسلامية}

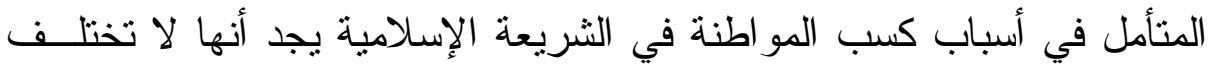

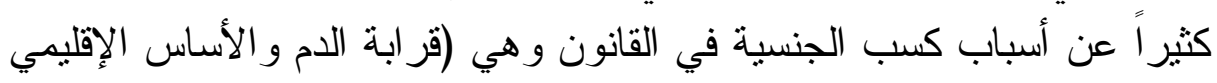

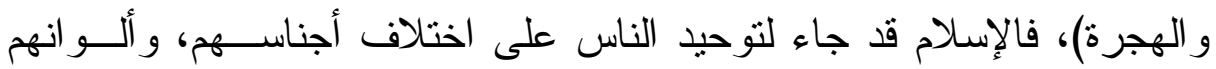

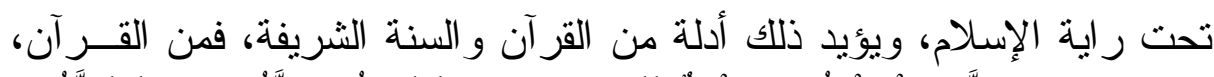

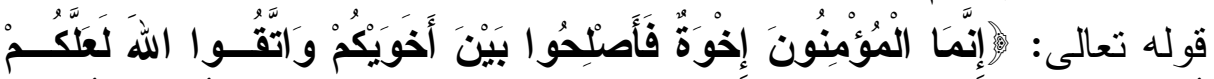

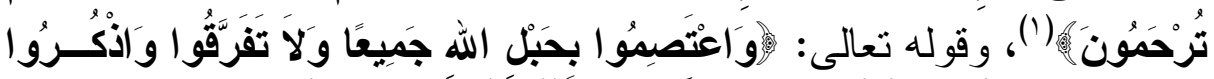

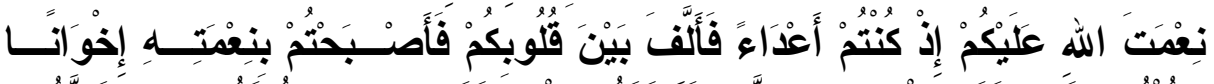

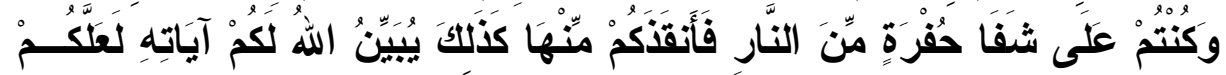

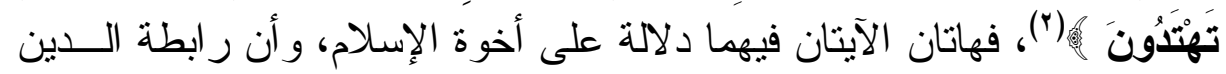

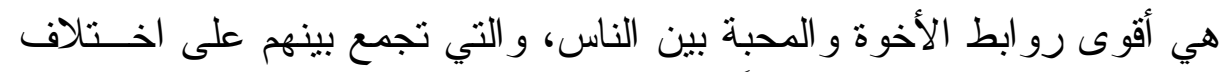

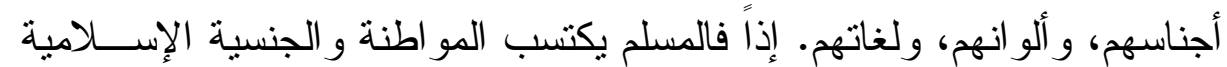
من لحظة و لادته، وهي تقابل الجنسية الأصلية في القانون الوضعي.

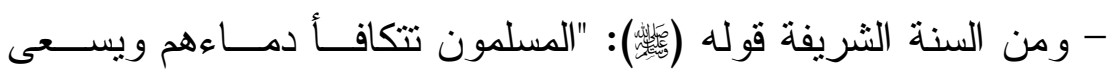

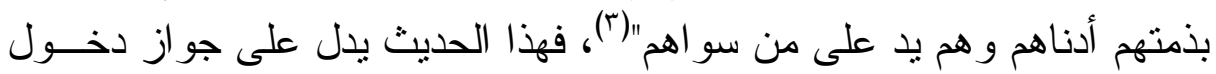

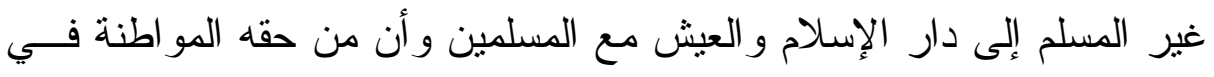

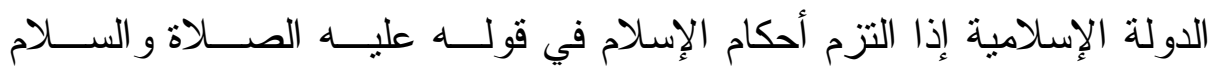

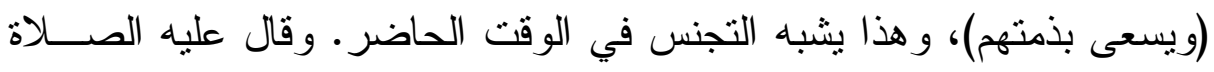

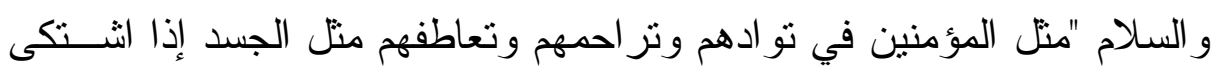

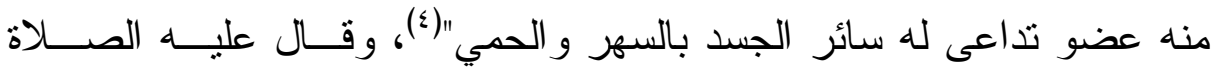

سورة آل عمرات، الآية (·) (1).

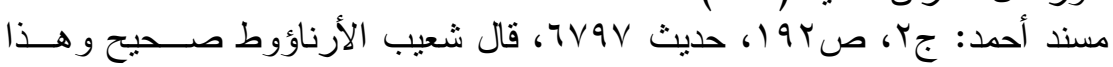

إسناد حسن.

صحيح مسلم، باب تراحم المؤمنين وتعاطفهم وتعاضدهم، ج\&، ص . . . ب، حديث 


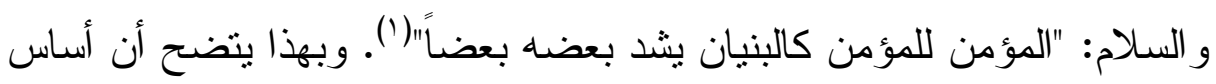

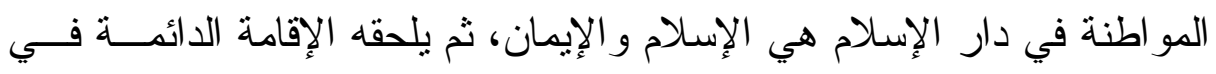
دار الإسلام بمقتضى عقد الذمة.

- و غني عن البيان أن الانتماء إلى الإسلام هو أساس الصــلـة الدينيــة

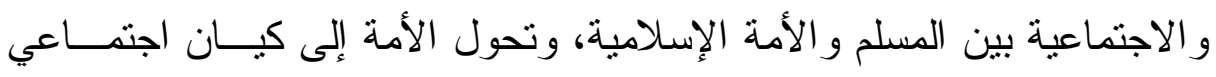

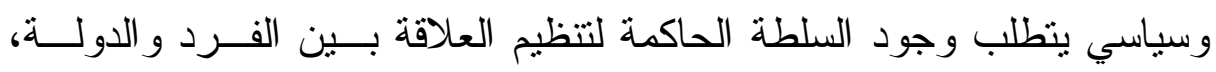

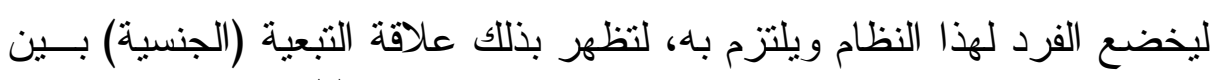

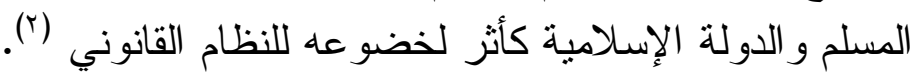

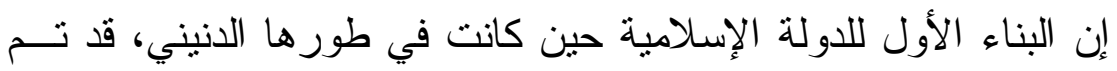

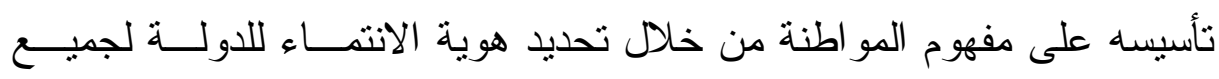

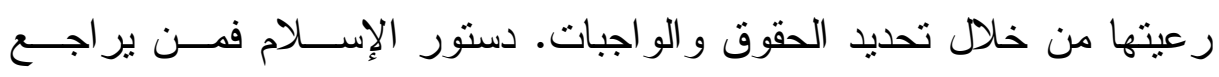

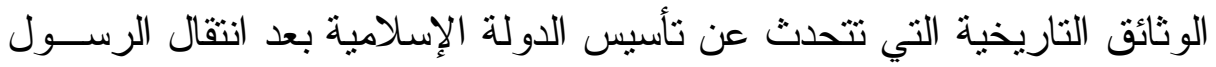

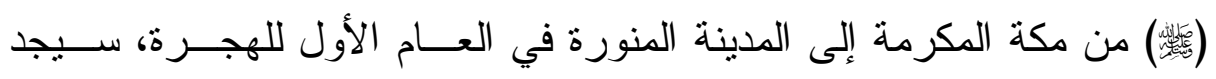

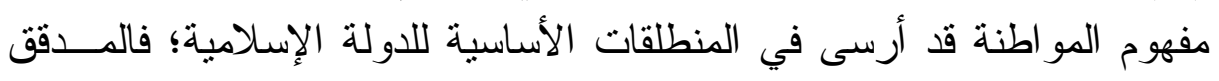

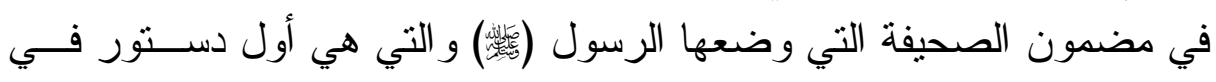

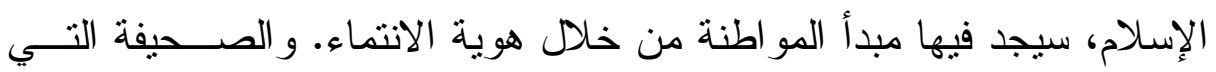

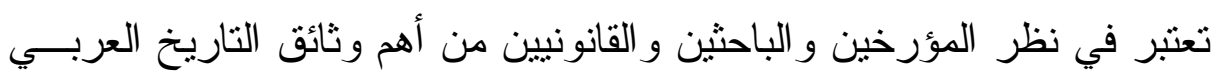

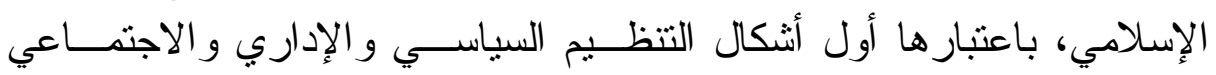

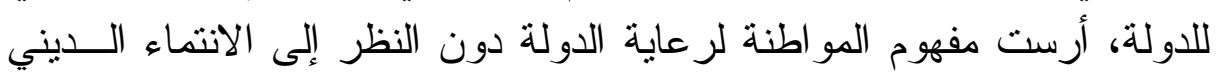

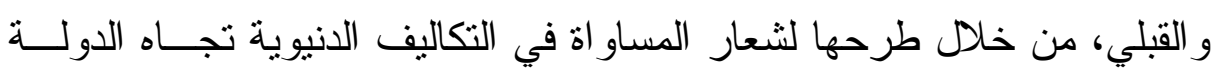

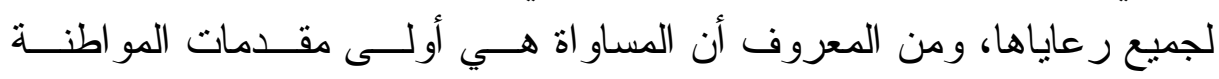

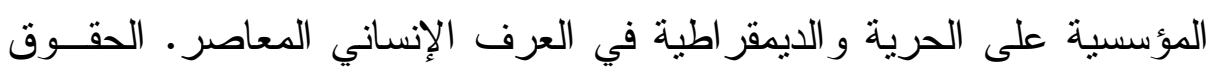

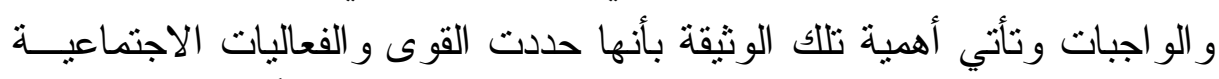

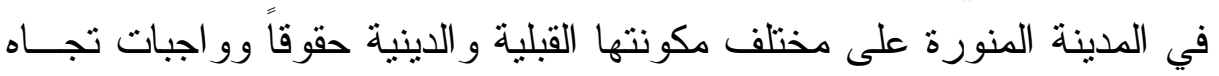

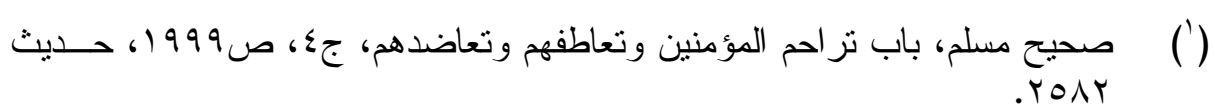

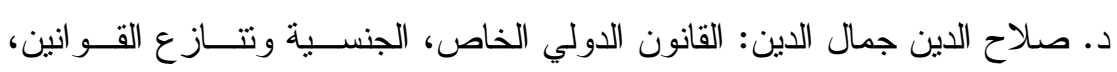

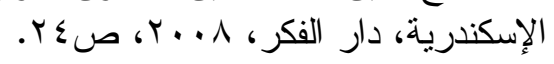


هذه الدولة الوليدة، ف مدن المعروف أن المدينة المنورة التـي هـــاجر إليهـــا

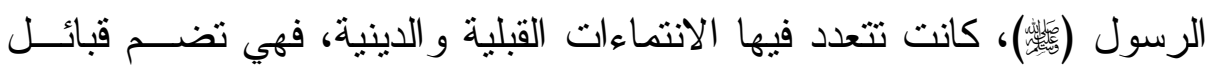

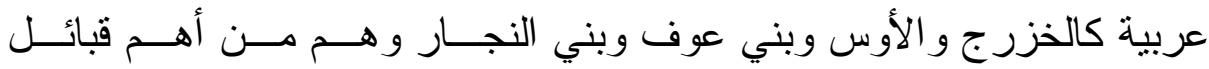

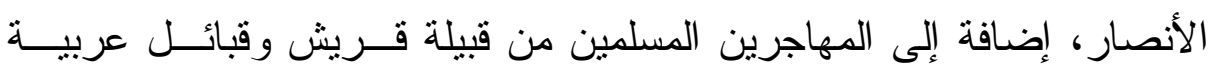

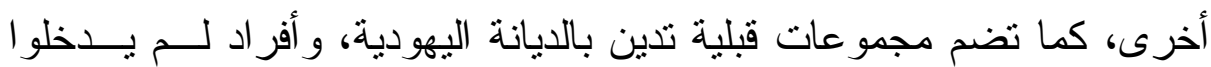

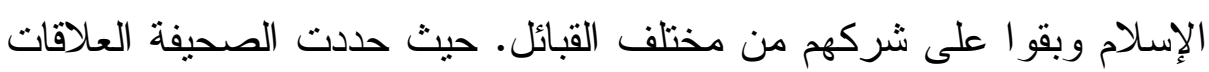

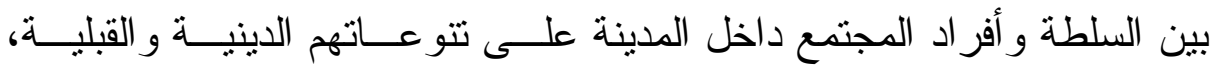

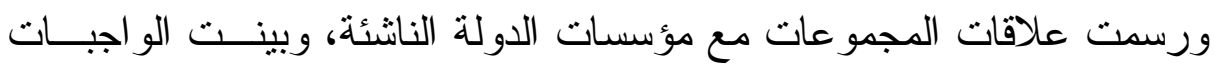

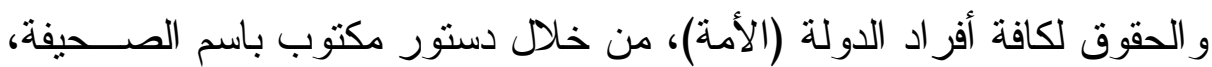

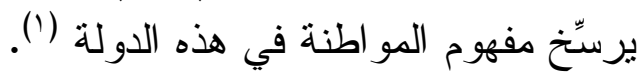
أسس المو اطنة:

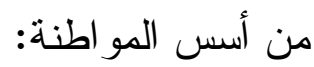

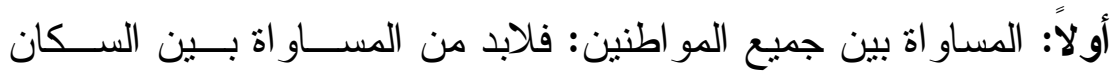

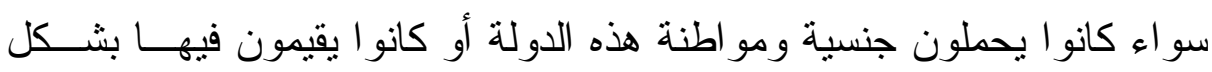

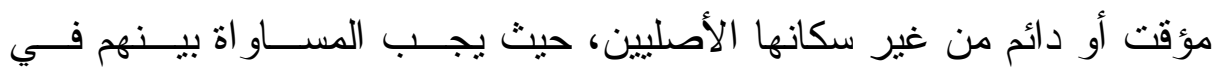

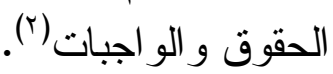

ثاتياً: المشاركة في الحكم (r) ثالثاً: الحرية و عدم استبداد الحاكم (£). حقوق و التزامات المواطنة:

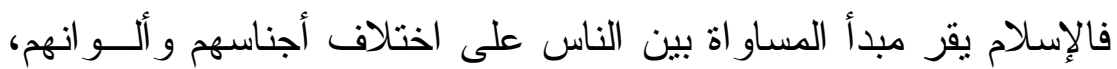

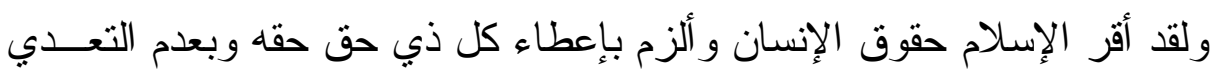

sug\&http://islamstory.com/detailes./php?module=artieal:

$$
\text { للمزيد ير اجع: }
$$

$$
\text { مفهوم المو اطنة-في -الدولة-الإسلامية. }
$$
نسرين عبد الحميد نبيه: مبدأ المواطنة بين الجدل والطية والنطبيــق، مركـز الإســكندرية

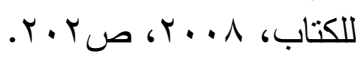

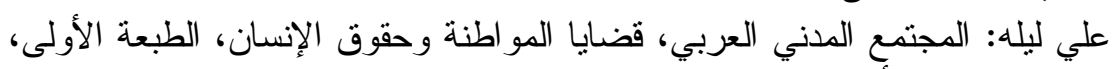

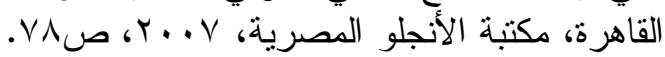

و هبه الزحيلي: آثار الحرب، در اسة فقهية مقارنة، الطبعــة الر ابعــة، دمثـق، دار

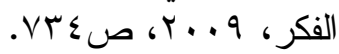


على حقوق الآخرين. و عندما منح الإسـام حق المو اطنة للمســلمين و غيــرهم ممن يعيشون في الديار الإسلامية رتب على ذلى ذلك حقوقاً و التز امات أهمها:

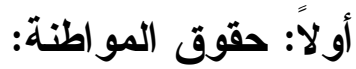

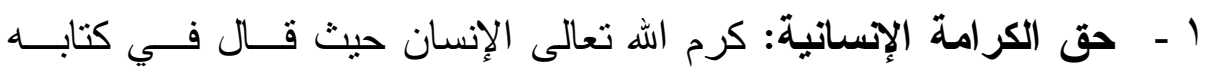

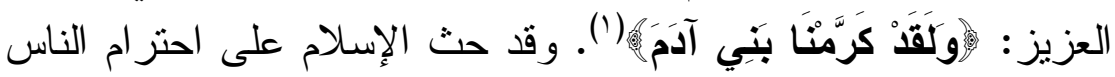

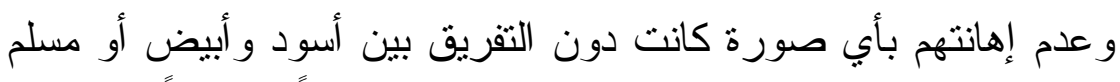

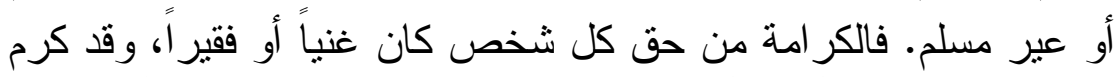

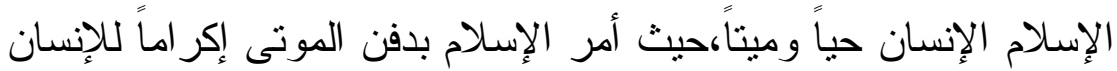

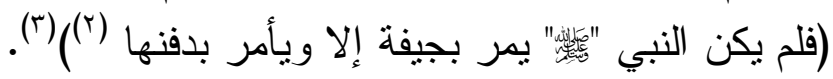

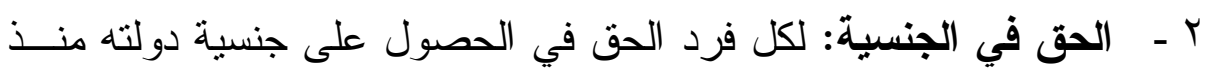

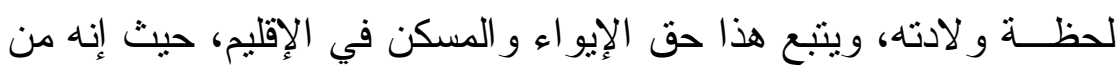

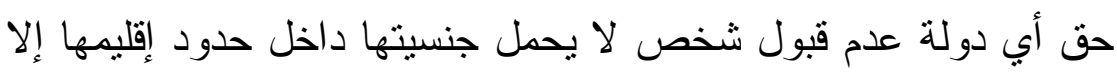

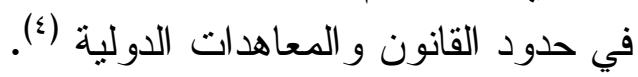

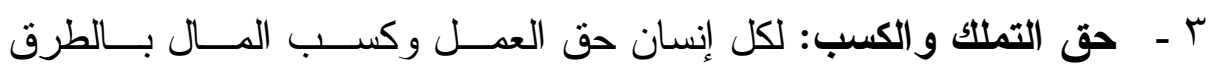

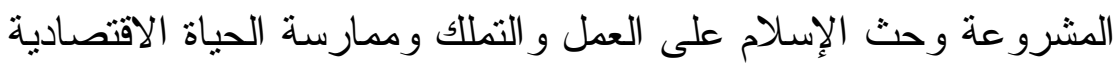

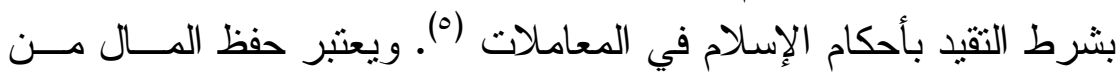

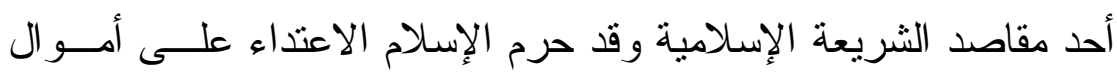

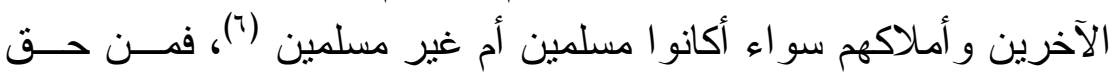

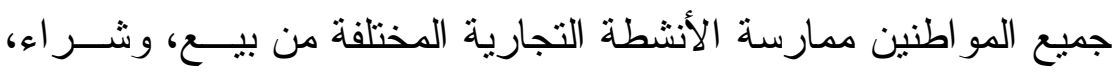

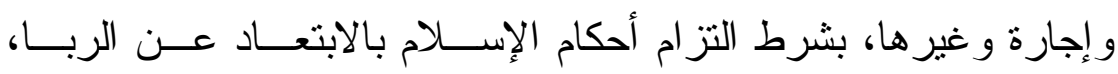

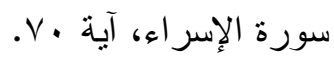

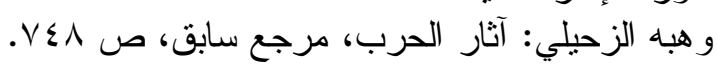

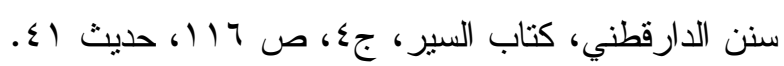

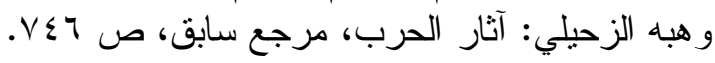

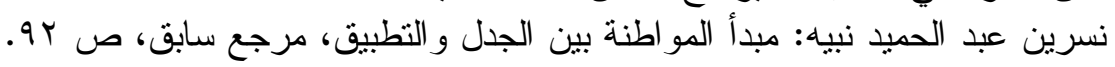


و الغش، و الاحتكار، وكل ما حرمه الإسلام في المعـاملات و أن تســود روح التسامح بين المو اطنين مسلمين و غير مسلمين. ـ - - حرية الاين والاعتقاد: لقد احترم الإسلام حرية الإنســان فـي اختيــار

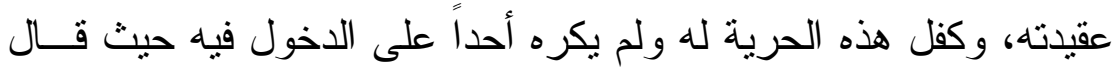

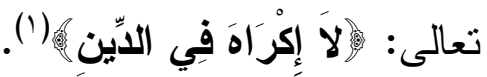

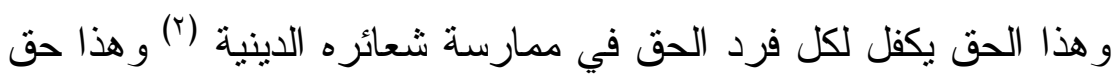

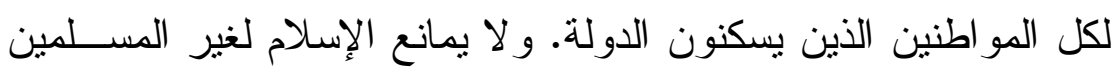

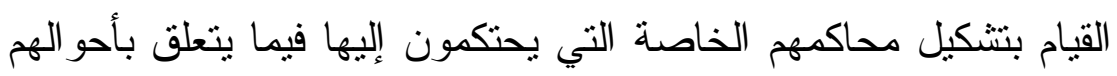

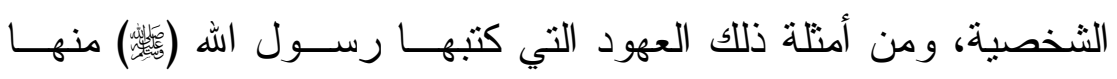

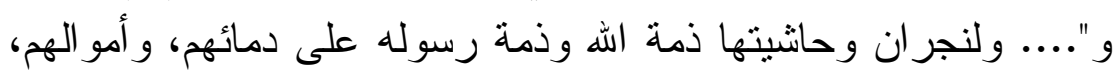

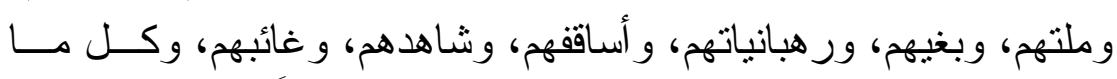

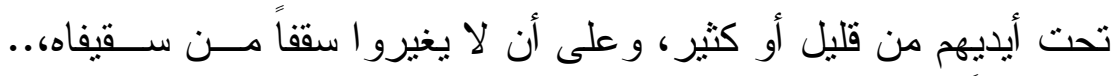

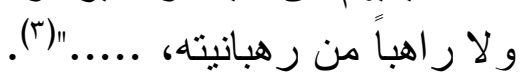

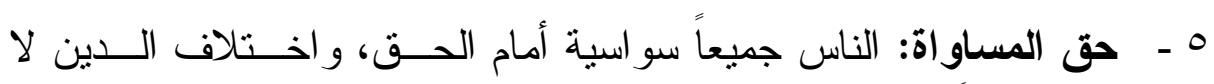

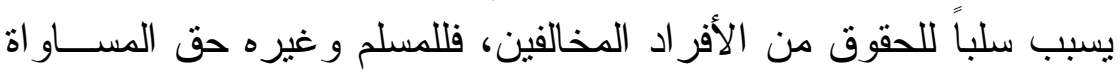

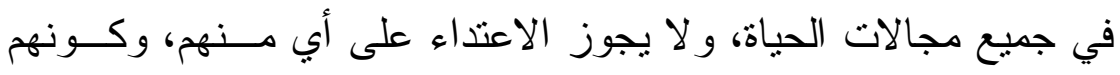

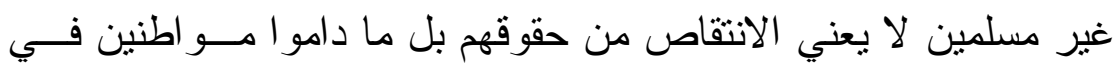

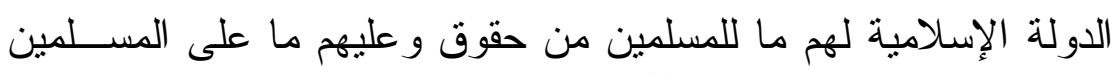

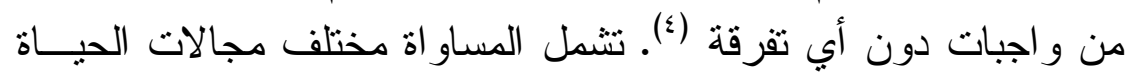

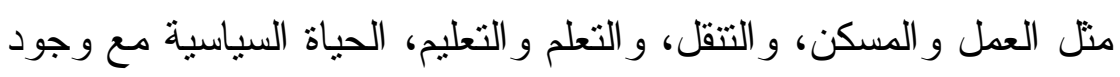

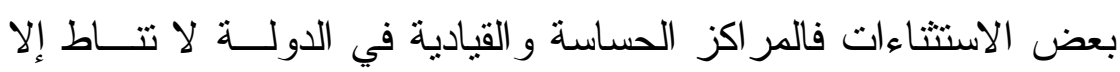
بالمسلمين منل قيادة الأمة ورئاستها.

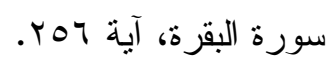
نسرين عبد الحمبد نبيه: مبدأ المواطنة بين الجدل و التطبيــق، مرجـع ســابق، ص

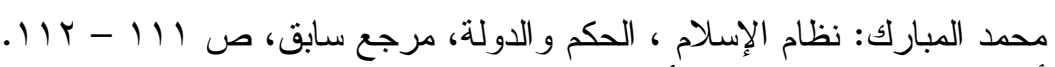

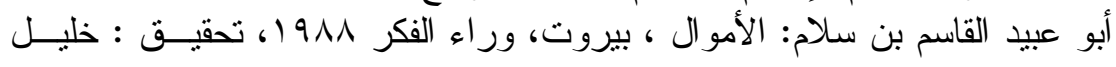

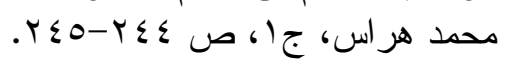


7 - الحقوق السياسية: ونتشل حق المشاركة في الانتخابات و التمثيل النيابي

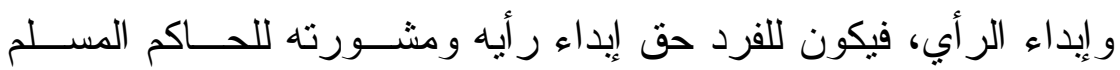

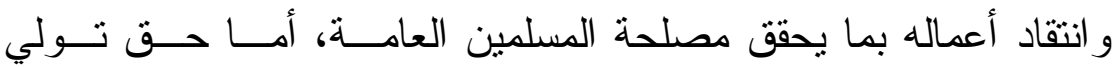

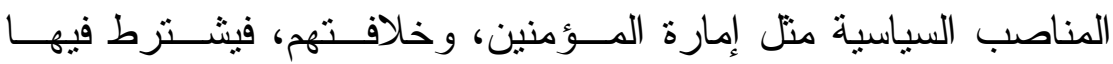

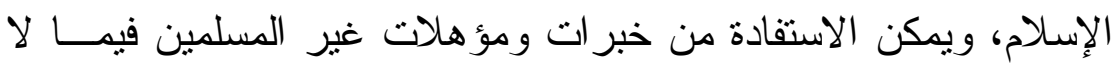

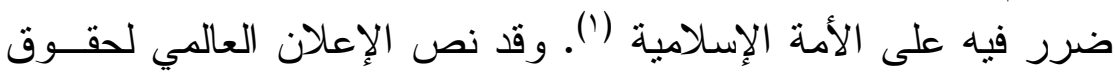

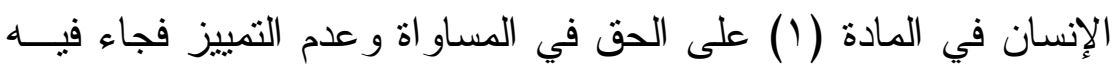

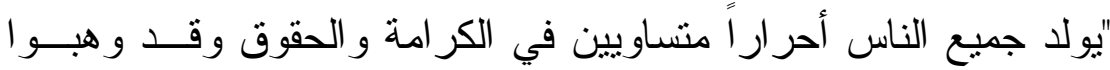

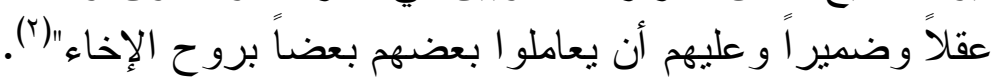
V - حرية التفكير والرأي: ويضمن هذا الحق لكل فرد في الدولة إبداء رأيه

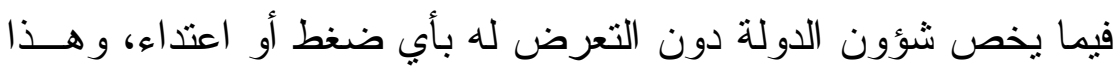

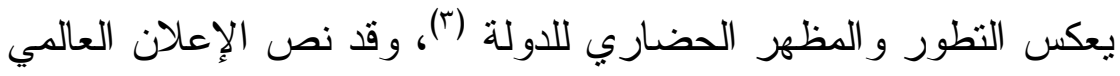

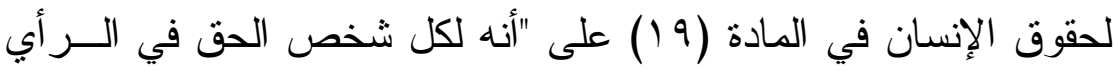

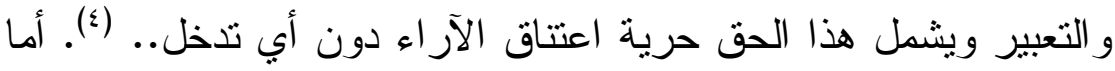

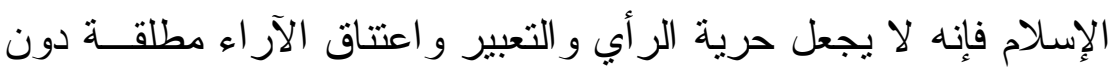

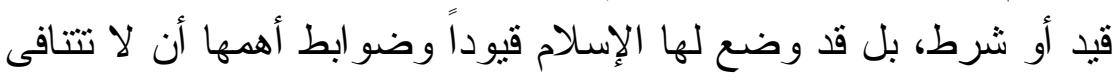

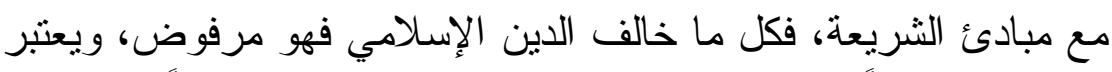

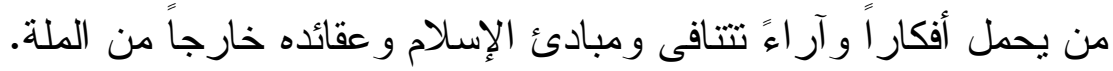

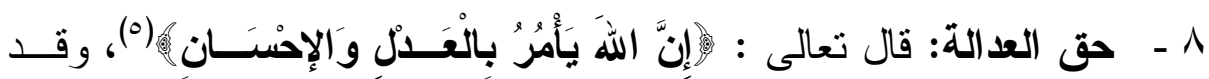

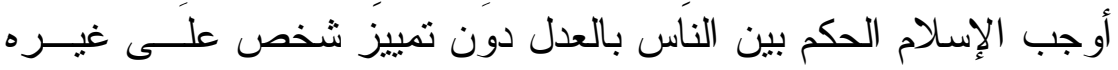

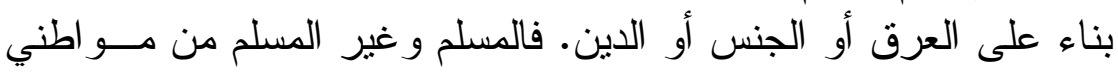

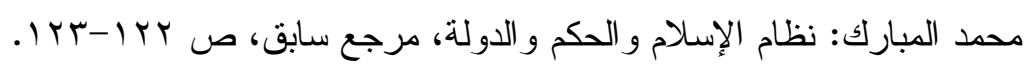

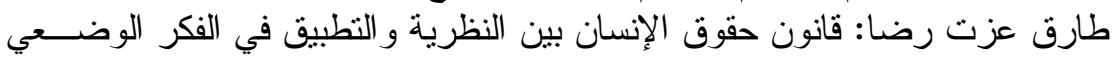

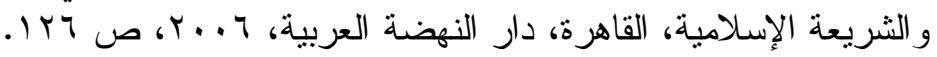

نسرين عبد الحميد نبيه: مبدأ المواطنة بين الجدل و التطبيق، مرجع سـابق، ص 99 .1..طارق عزت رضا: قانون حقوق الإنسان بين النظرية و النطبيق في الفكر الوضـــي

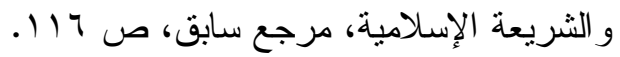

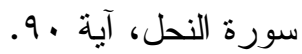

= إطلالة على الجنسية في الفقه الإسلامي والقانون الدولي الخاص 


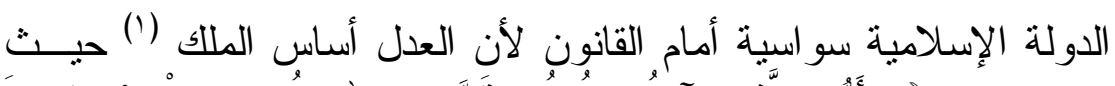

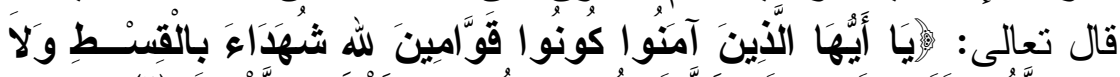

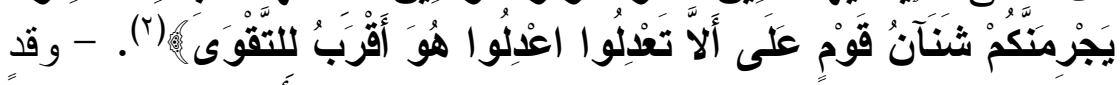

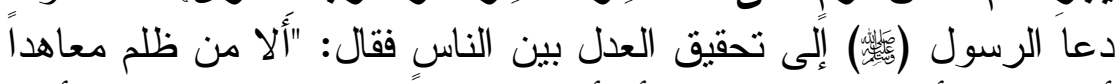

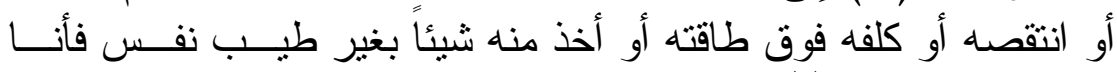

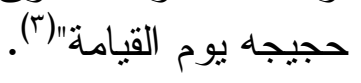

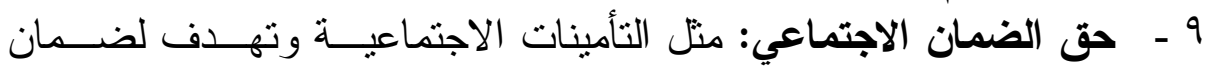

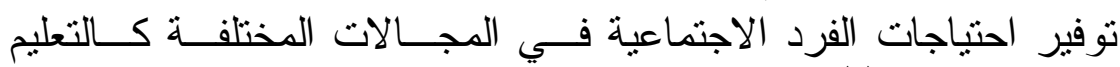

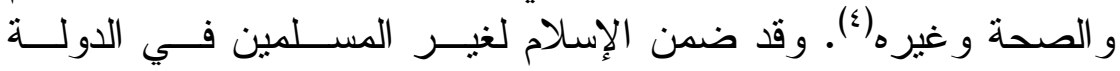

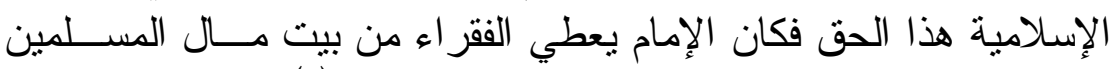

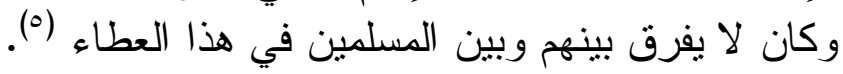

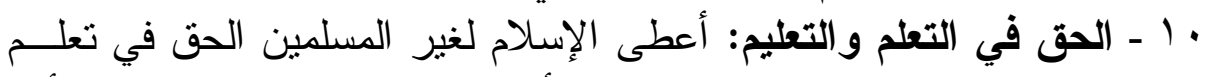

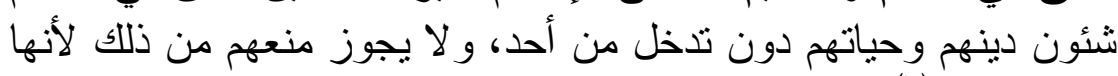

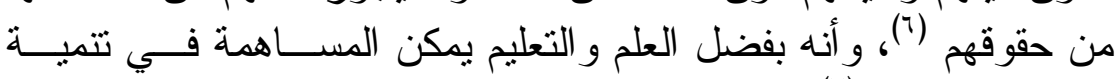

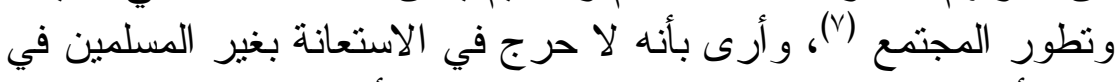

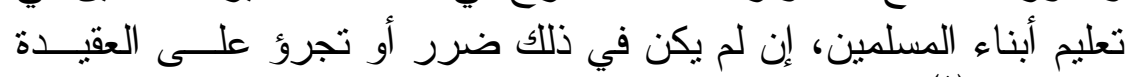
الإسلامية (")

$$
\begin{aligned}
& \text { و هبه الزحيلي: آثار الحرب، مرجع سابق، ص V01. } \\
& \text { سورة المائدة، آية } 1 .
\end{aligned}
$$

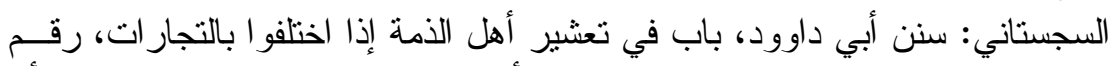

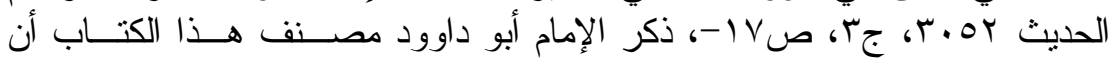

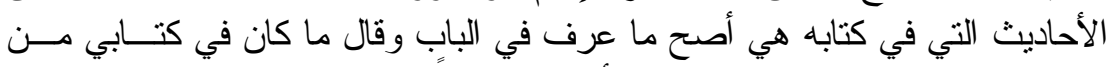

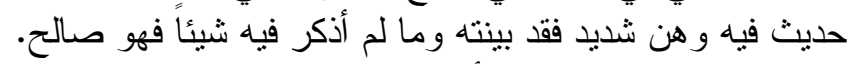

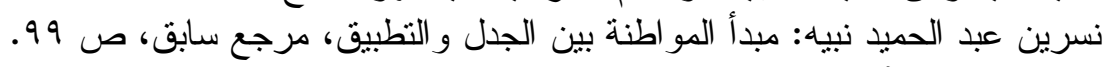

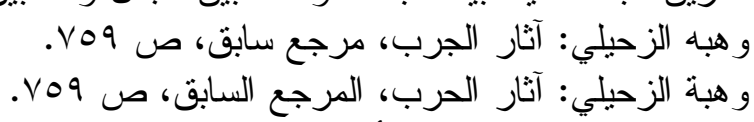

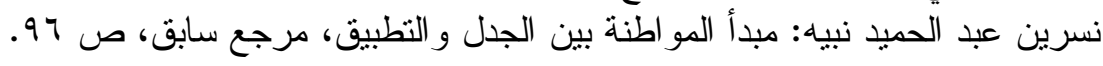

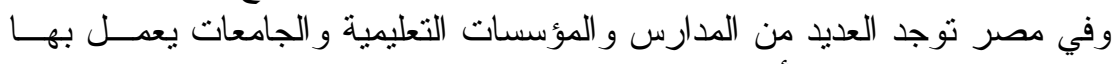

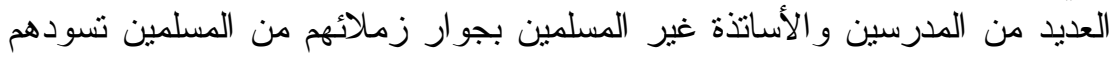

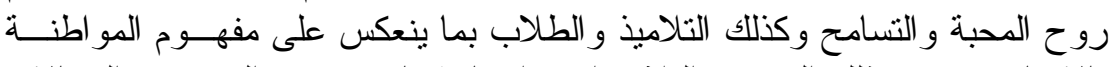

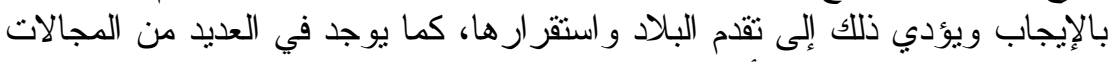

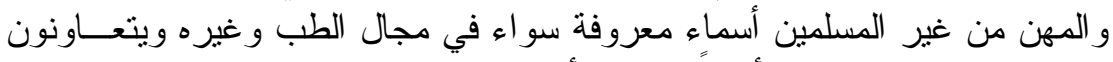

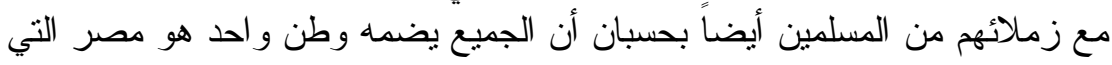
تحنوي الكافة. 
11 ـ الحريات الثخصية: وتشمل حرية المسكن و العمل، و التتقل داخل البلــــ

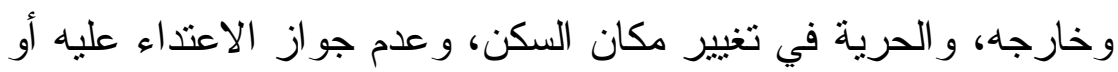

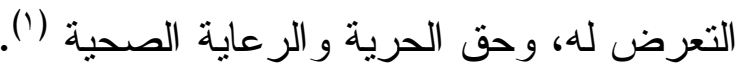

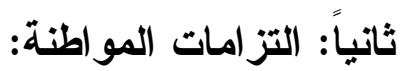

الولاء والإخلاص للاولة: دعا الإسلام إلى حب الوطن، و الانتماء إلبــــ

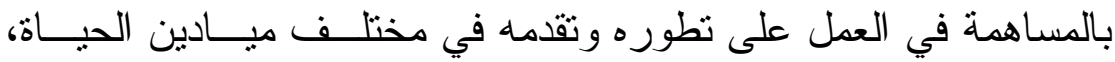

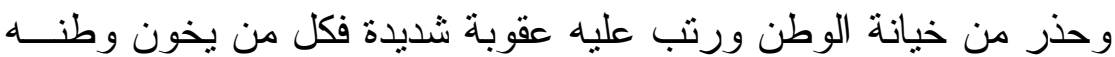

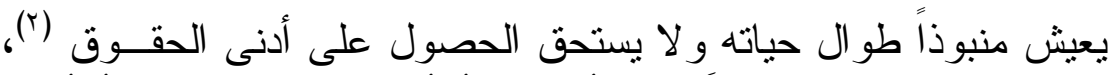

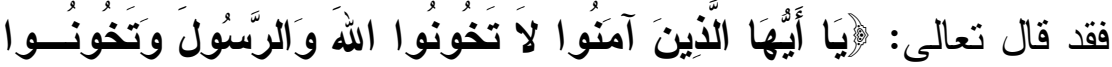

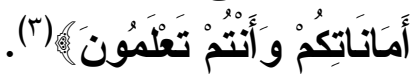

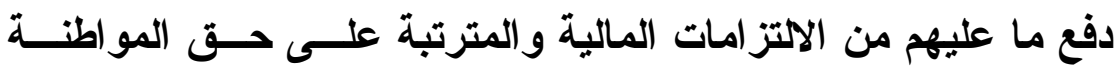

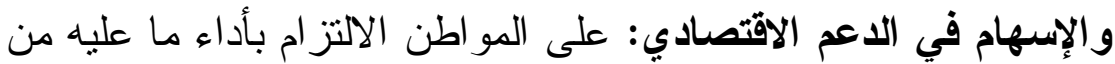

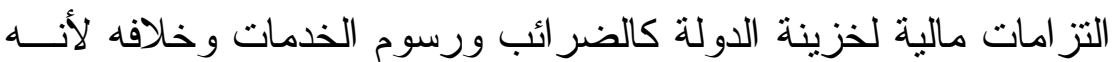

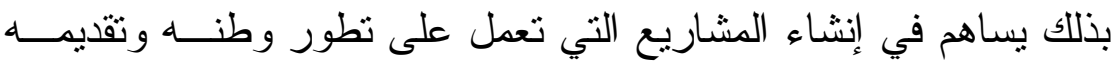

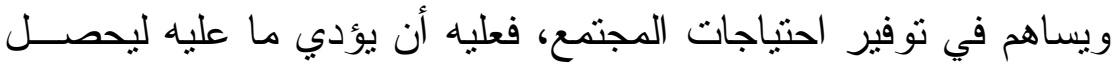

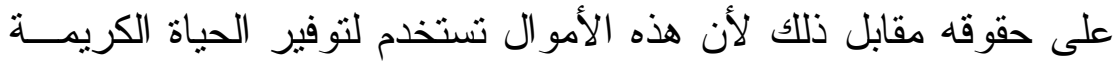

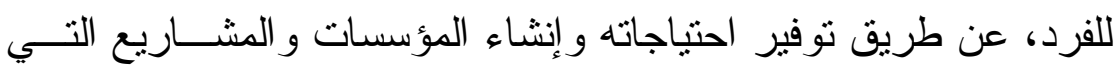

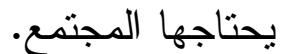
التزام القوانين (๕): لأن ذلك يؤدي إلى انتشار الأمن و الطمأنينـــة فــي

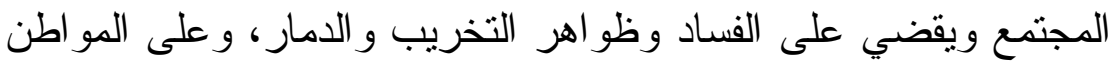

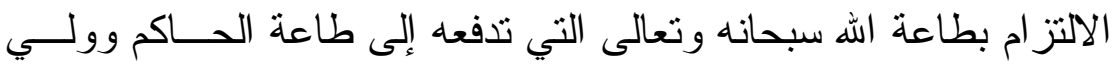

الحسن بن طلال: حول المو اطنة في الوطن العربي، الطبعة الأولى، عمان: منتــى

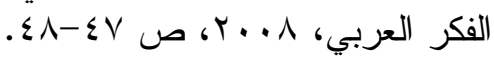

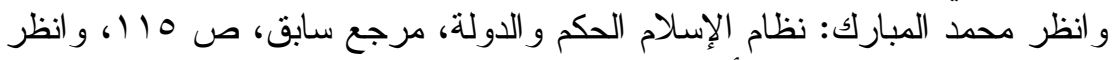

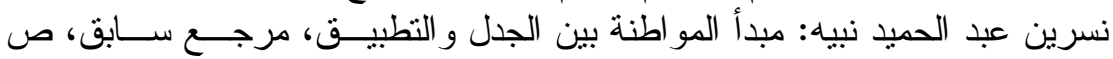
.) .

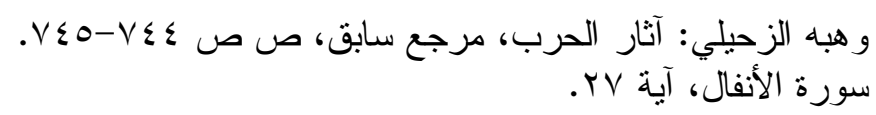

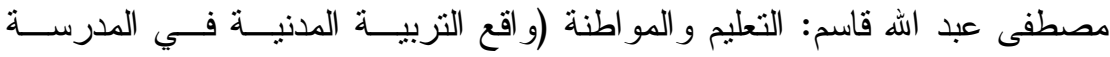

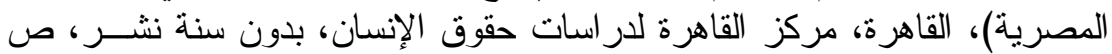


الأمر و التز ام القو انين، و الالتز ام بأحكامه وتحقيق التكافــلـ الاجتمـــاعي ومحاربة كل ما فيه ضرر على المجتمع (').

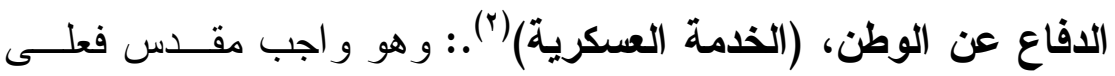

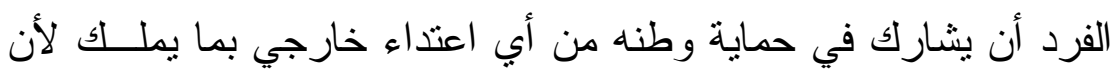

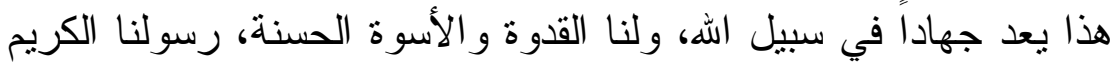

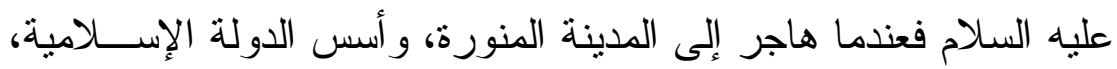
غرس في المسلمين حب الوطن و الدين، فبذلو ا أرو احهم و أمـــو الهم فـي الإني

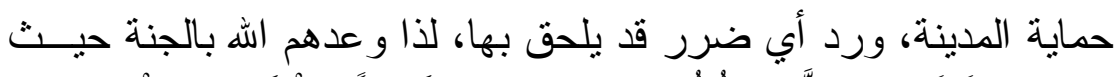

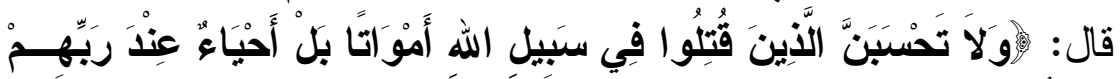

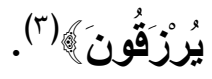

\section{الفرع الثالث}

\section{دور الأزهر في نشمر ثقافة المواطنة}

لقد أصبحت المواطنة من الآليات المهمة للحد من الصر اعات العرقية و الاجتماعي و غير ها استتاداً على قاعدة مبدأي - عدم التمييز و المساو اة.

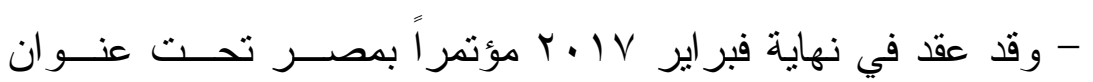

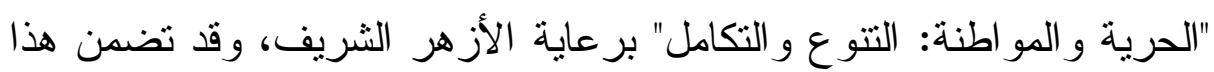

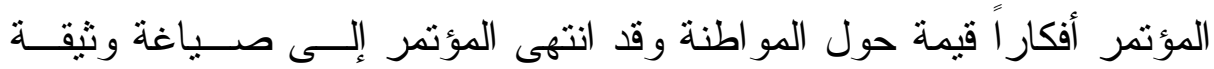
معتبرة وتاريخية أنجزت عدة أمور :

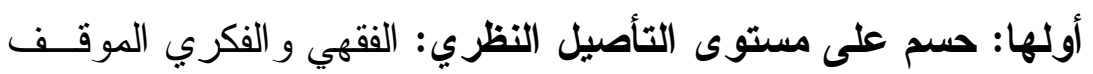

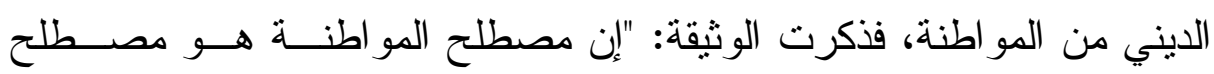
أصيل في الإسلام وقد شعت أنو اره الأولى من دستور المدينة".

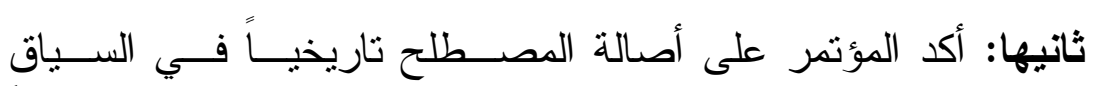

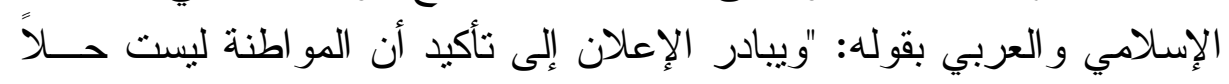

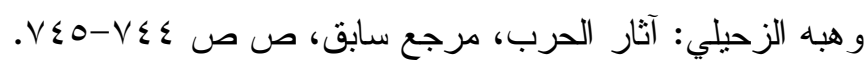

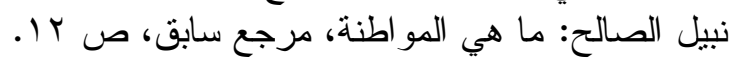

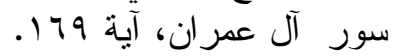


مستوردا". فلقد مورس في دولة المدينة، حيث الجميع لهم نفس الحقوق و عليهم نفس الو اجبات دون تمبيز أو تفضيل.

ثالثها: أن مبدأ المو اطنة هو القاعدة المتينة التي تؤسس لكــل مــن ت

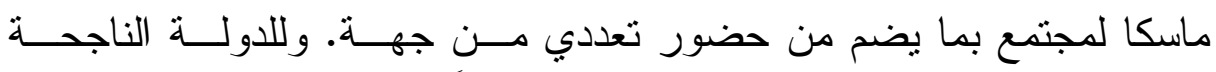

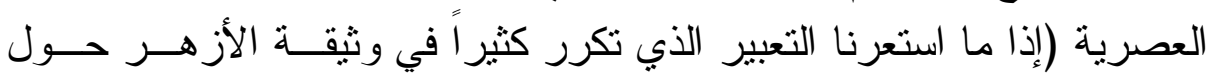
مستقبل مصر الذي نتج عن نقاشات مطولة بين علماء الأز هر ومثقفي مصــر

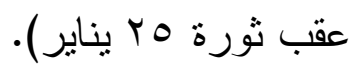

\section{- وقد أثنارت وثيقة المو اطنة (') إلى ما يلي:}

"أن أول عو امل التماسك وتعزيز الإز ادة المشتركة يتمنثل فـــي الدولــة

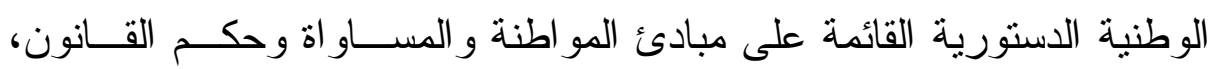
و على ذلك فإن استبعاد مفهوم المو اطنة بوصــفه عقــداً بــين المــو اطنين...

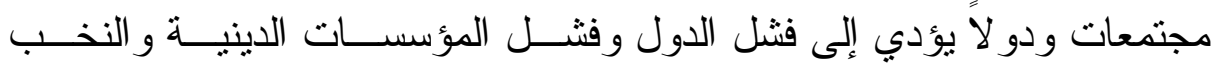
السياسية و التقافية وضرب ودوب التتمية و التقدم"

رابعاً: أما رابع ما أنجزه المؤتثر هو وضوح موقفــهـ بــأن "تجاهــلـ

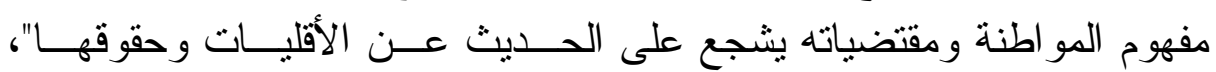

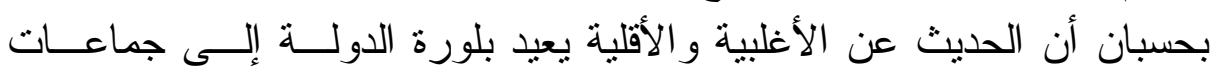
"موز عة الو لاءات" بحسب تعبير الوثيقة.

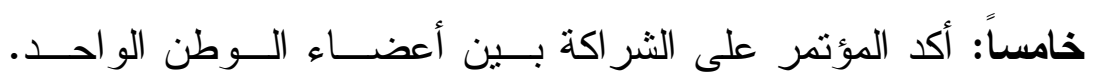
"فالمظالم مشتزكة و المصالح مشتركة". وهو ما يقتضي عملاً مشتزكا، و العمل المشترك هو التعبير المعاصر عن المواطنة في إطلار الدولة الوطنية الحديثـة مهنة

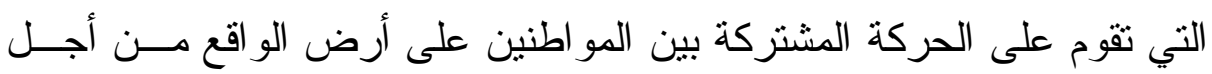

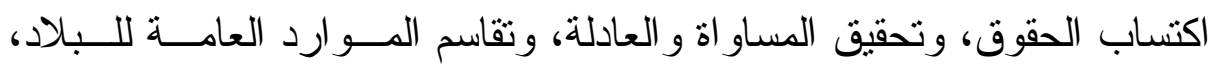

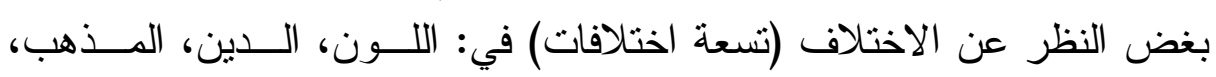

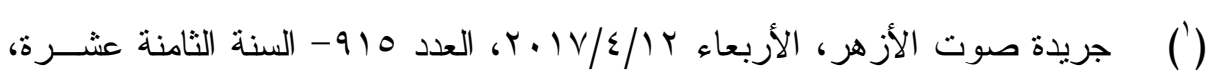
الصفحة الثالثة. 


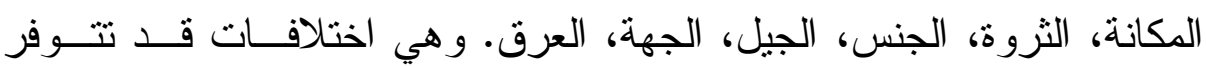

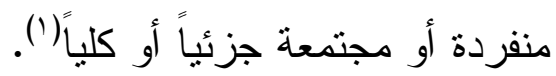

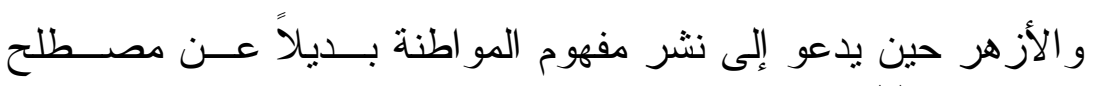

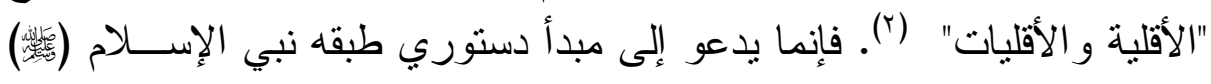

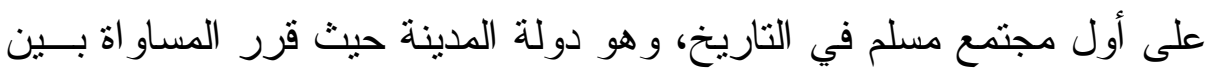

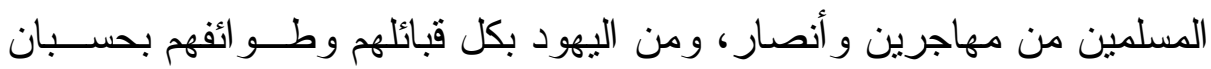

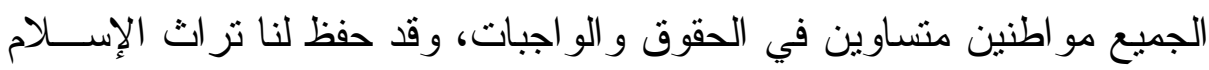

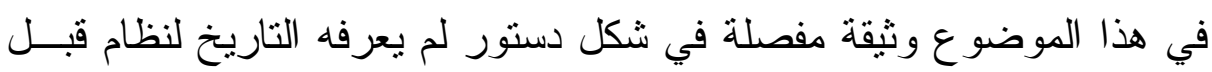

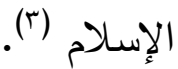

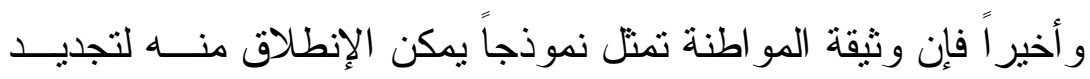

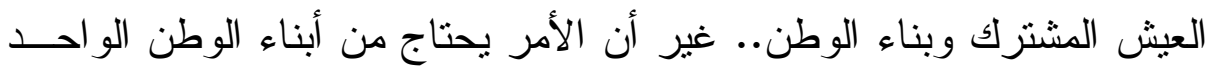

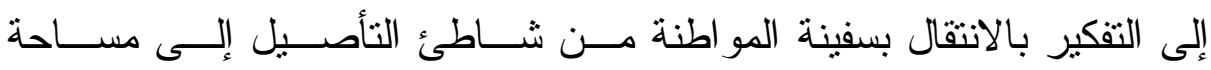
التقعبيل (")

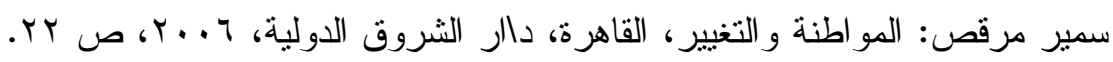

حيث أكد الأزهر الثريف عدم استخدام مصطلح الأقليــات فـي جميــع الأدبيــات و الثقافات و المناهج التعليمية لأن هذا المصطلح يوحي بالتمييز في حد ذاته واسته واستخدام

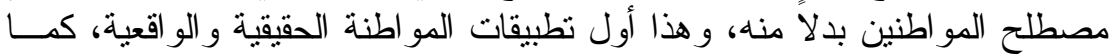

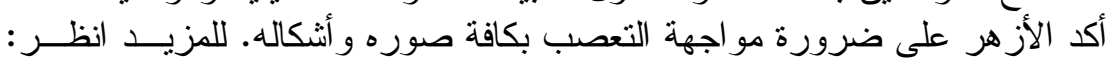

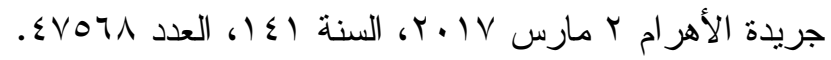

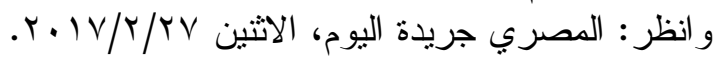

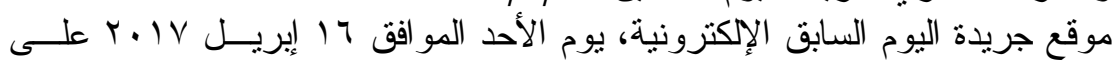
http://ww.youm7.com/3122477. الر ابط:

وقد خصص فضيلة الإمام الأكبر شيخ الأزهر فصلاً كاملاً من فصول كتاب "الثقافة

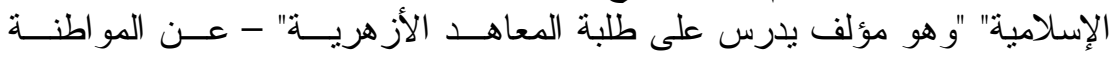

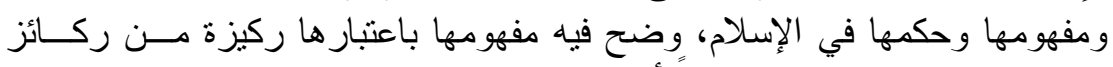

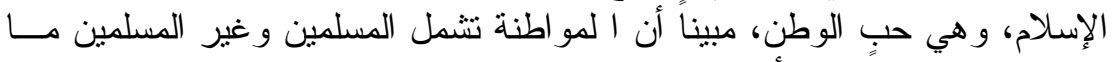

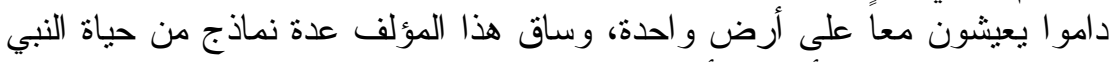

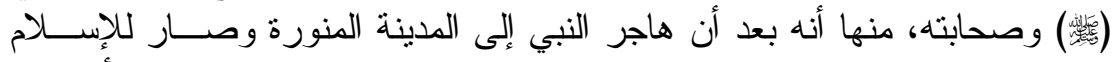

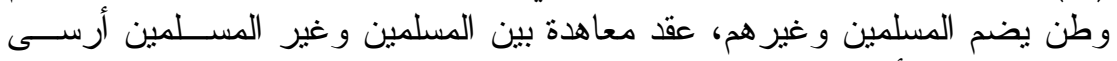

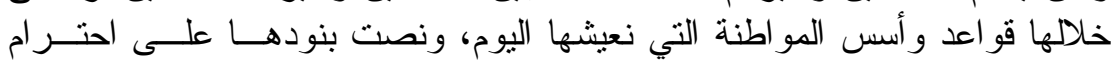




\section{الفرع الرابع}

\section{هقيقة المواطنة في القانون الدولي والإعلان العالمي لهقوق الإنسان}

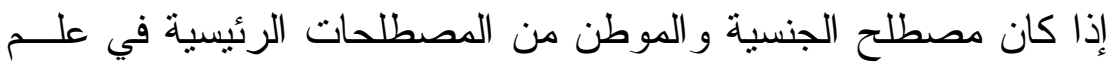

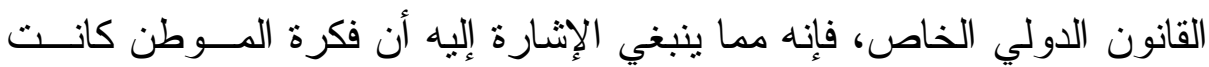

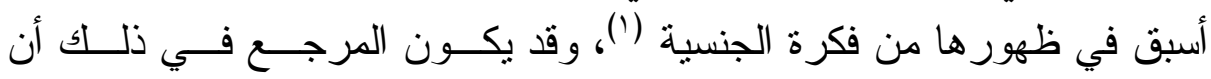

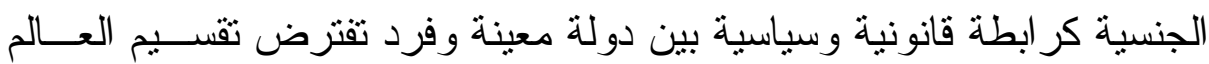

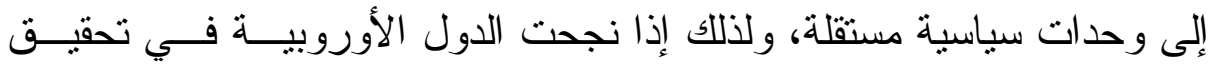
الوحدة السياسية دون أن يعاصر ذلك توحيد شامل للقو انين سوف تفقد الجنسية

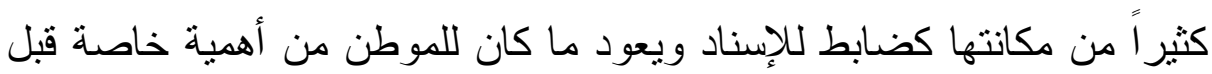

ظهور الجنسية (r).

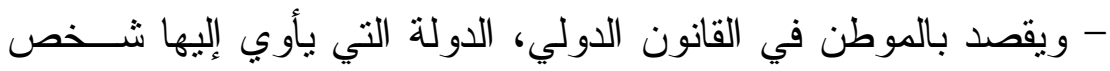

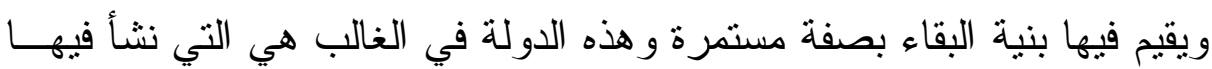

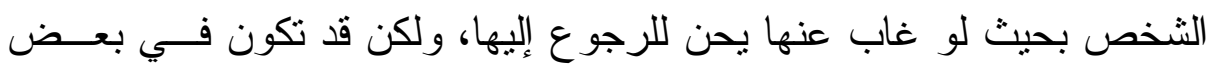

الأديان و المقدات وحقوق الإنسان ومنع الظلم و الاعتداء و الجور، وبعد أن عقد تلاك

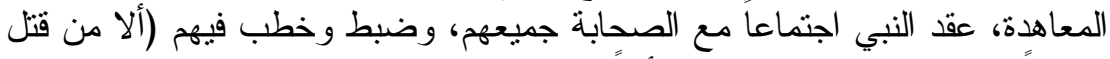

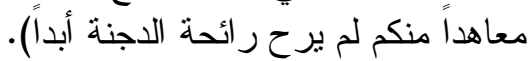

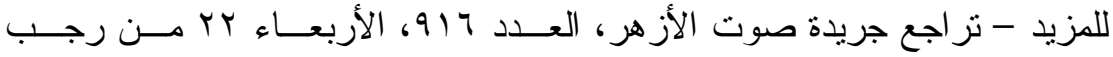

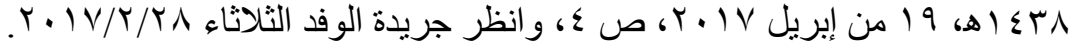

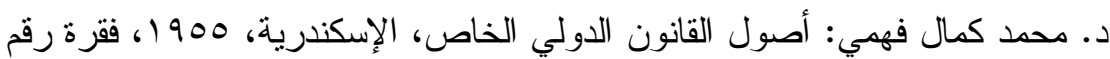

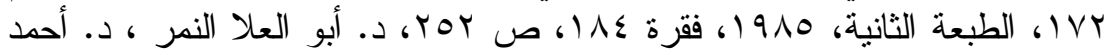

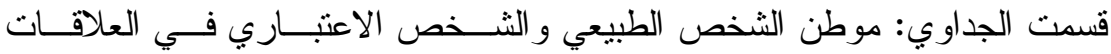

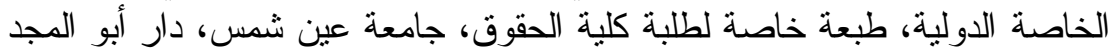

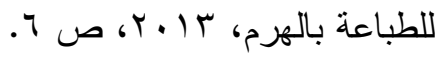

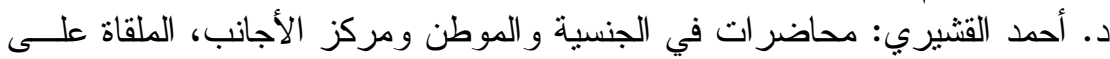

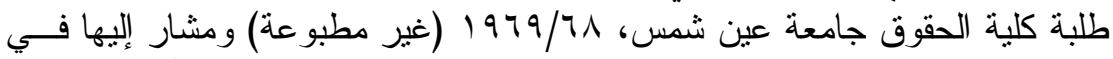

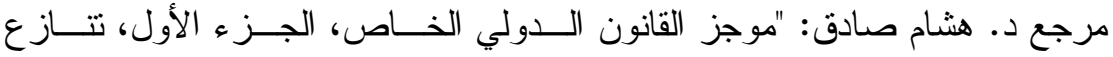

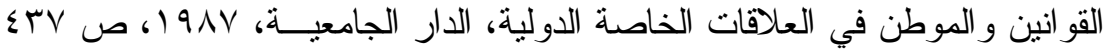


الأحيان التي هاجر الثخص إليها لتكون مأوى نهائياً له يقضـــي فيــه حياتــهـ

ويكسب فيه عيشه (')

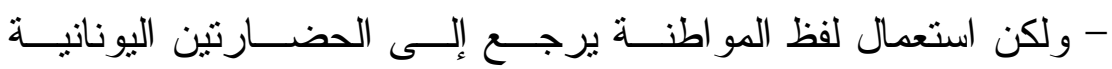

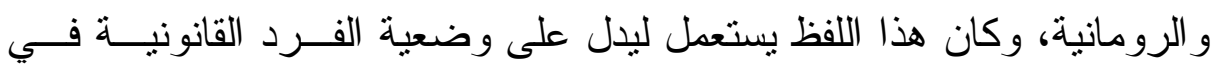

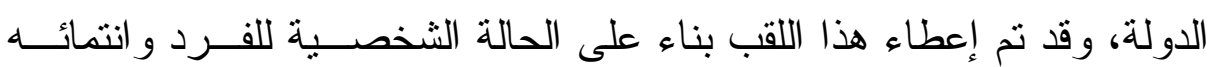

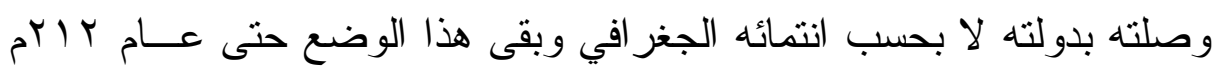

- ثم أخذ هذا المفهوم بالتطور كلما زادت مشاركة الفرد في الدولة، ذلك

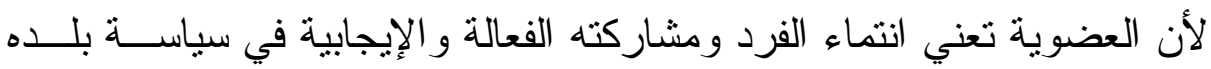
و أمنه و العمل على تطوره وتقدمه (َّ).

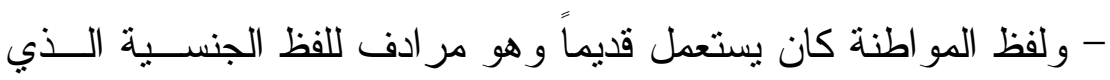

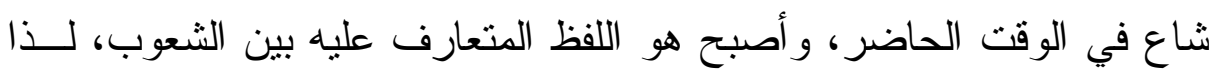

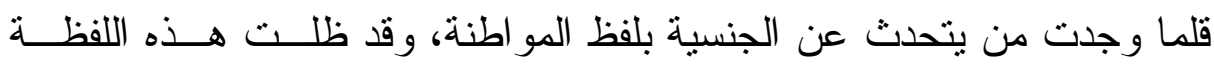

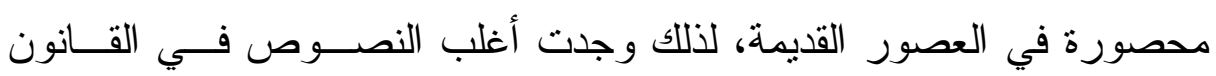

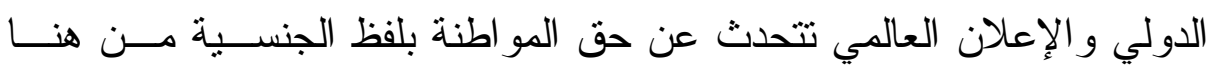

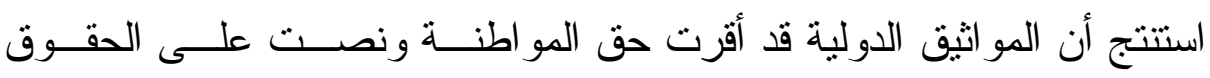

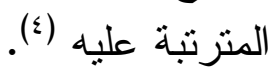

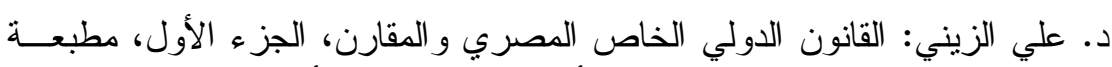

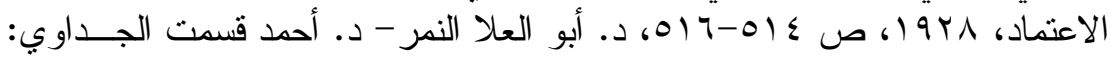

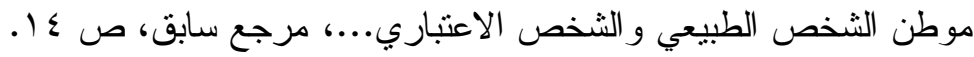

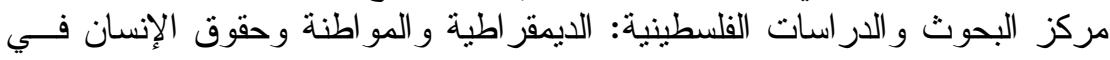

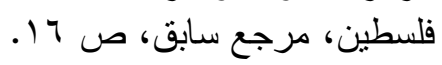
مصطفى عبد الله قاسم: التعليم و المواطنة اطنة (و اقع التربيــة المدنيــة فـــي المدرســـة

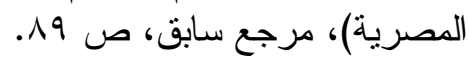

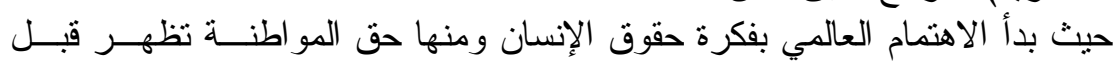

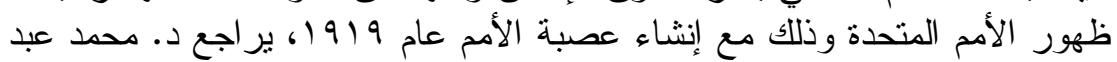

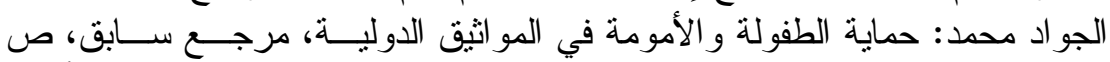

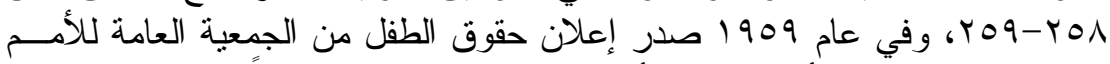

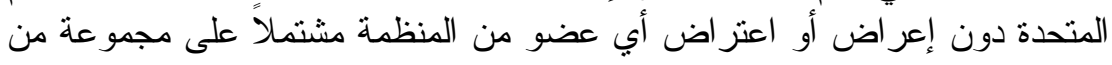


كما تتص المادة الأولى من دستور جمهورية مصر العربية الصادر عام

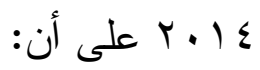

"جمهورية مصر العربية دولة ذات سيادة موحدة لا تقبـل التجزئسـة و لا ينزل عن شيء منها، نظامها جمهوري ديمقر اطي، يقوم على أساس المو اطنـة وسيادة القانون، و الثعب المصري جزء من الأمة العربية بعمل على تكاملهــا ووحدتها، ومصر جزء من العالم الإسـامي، تتتمي إلى القارة الإفريقية، وتعنز بامتدادها الآسيوي، وتسهم في بناء الحضارة الإنسانية". كما تتص م ب من ذات الدستور على أن: "السيادة للشعب وحده يمارسها ويحميها وهو مصدر السلطات ويصــون

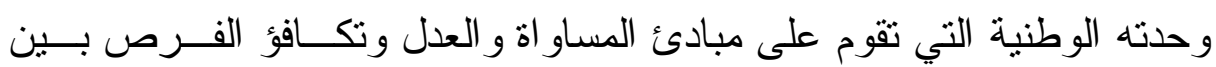
جميع المو اطنين، وذلك على الوجه المبين في الدستور ". كما تتص المادة 9 من الدستور على أن:

"تلتزم الدولة بتحقيق تكافؤ الفرص بين جميع المو اطنين دون تمبيز ". وقد سبق الإسلام المو اثيق الدولية في إقرار مبدأ المواطنة وتتظيم علاقة الدولة الإسلامبة بغير ها من الأمم الأخرى بوضع ما يسمى (صحيفة المدينة). - و أن الإسلام يعتبر المو اطنين متساويين في الحقوق و الو اجبات، وهذا ينطبق على غير المسلمين الذين يعيشون في الدولة الإســلامية، لأن الإســالام دين عالمي يعتبر جميع الناس أمة و احدة، و لا يفرق بينهم على أساس اللون أو الجنس أو الدين بل يعامل الجميع على قدم المساو اة ( ).

المبادئ كحق الإنسان في الاسم و الجنسية و إلى تلافي مشكلات عــديمي الجنســية،

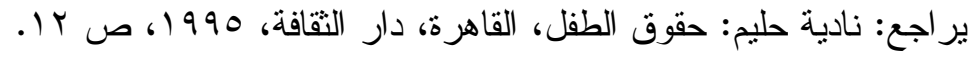

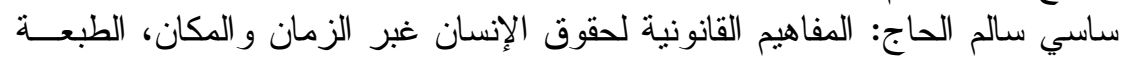

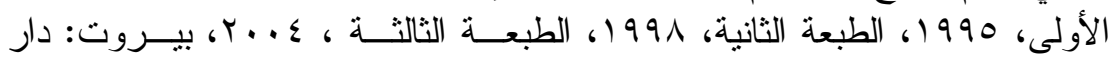

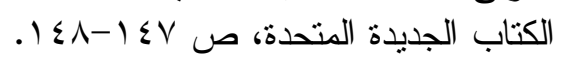




\section{الإلبب الثاني \\ وجود البنسية في الفقه الإسلامي}

لقد جاء الإسلام للناس كافة لتوحيدهم تحت ظل مجتمع وشريعة واحدة،

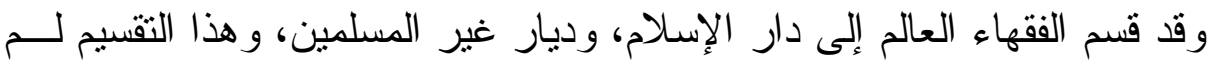

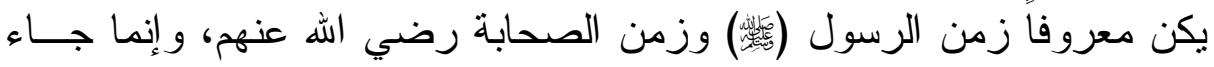

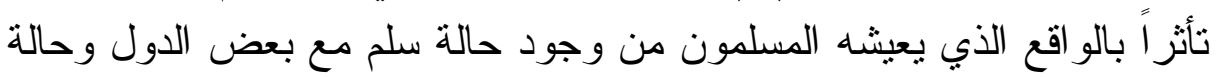

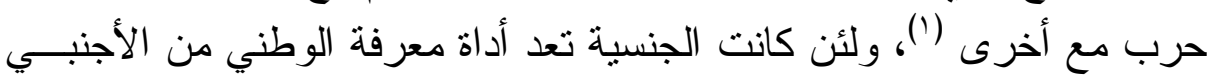
إلا أن وجودها في الفقه الإسلامي يرتبط بفكرتين أساسيتين:

الأولي: وجود الجنسية في الفقه الإسلامي وارتباطها بجانب العقيدة. الثانية: و جود الجنسية في الفقه الإسلامي وارتباطها بجانب الثريعة.

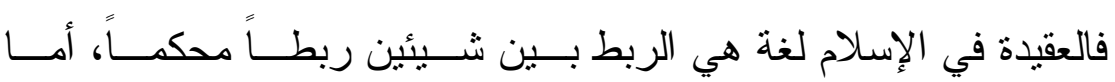

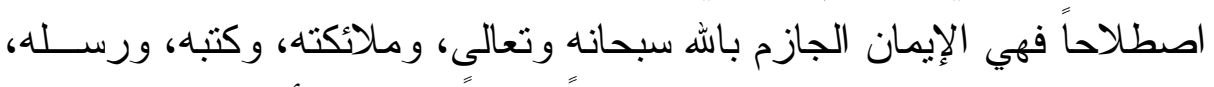

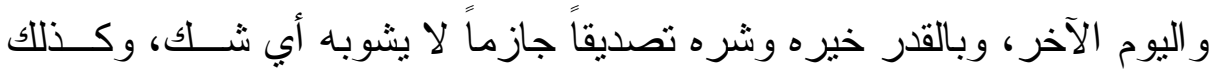

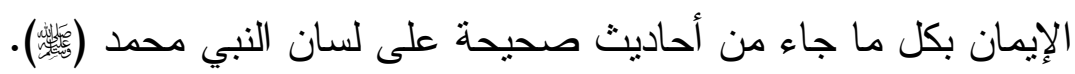

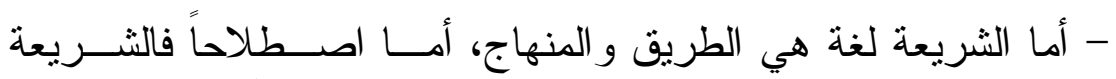

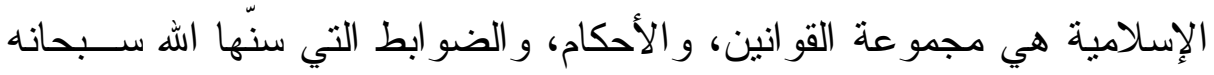

وتعالى بهذف تتظيم شؤون حياة الناس و علاقاتهم و أعمالهم المختلفة (؟).

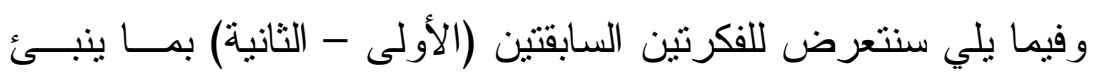

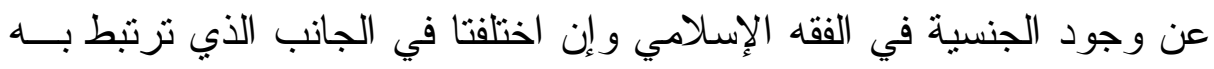
فكرة الجنسية، فالفكرة الأولي نزبطها بجانب العقيدة، وهي في ذلك الكت ستصل في

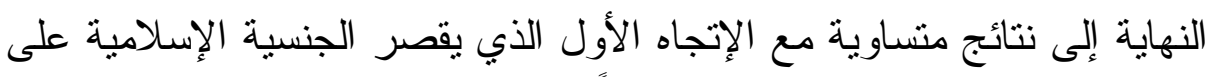

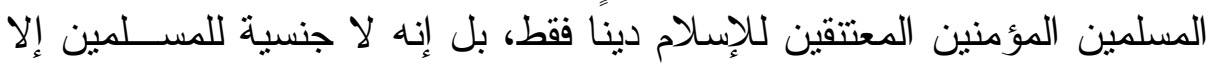

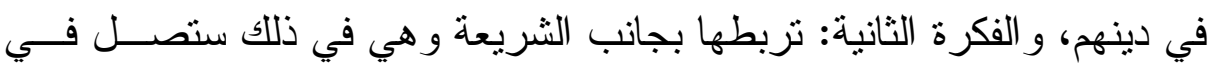

د. عارف خليل أبو عيد: العلاقات الدولية في الفقه الإسلامي، الأردن، دار النفائس،

$\left({ }^{2}\right)$ http://mawdoo3.com

= إطلالة على الجنسية في الفقه الإسلامي والقانون الدولي الخاص:ال 
النهاية إلى تمتع المسلمين، و أهل الذمة بالرعوية الإسلامية (')، على ما سوف نرى لاحقًا، وسنبين ذلك بشيء من التقصيل في فر عين:

\section{الفرع الأول}

\section{وجود البنسية في الفقه الإسلامي وارثباطها بمانب العقيدة}

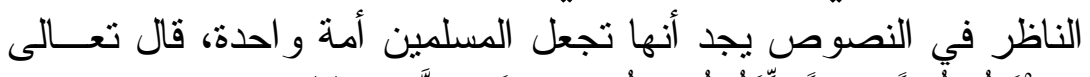

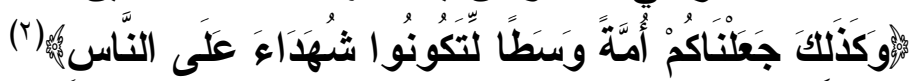

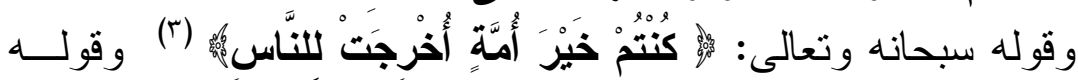

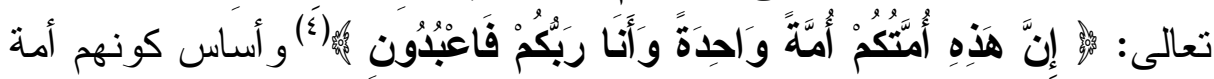

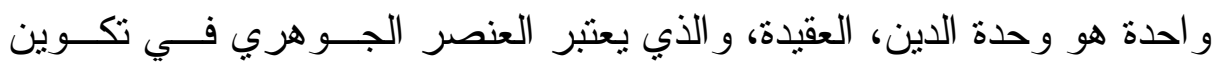

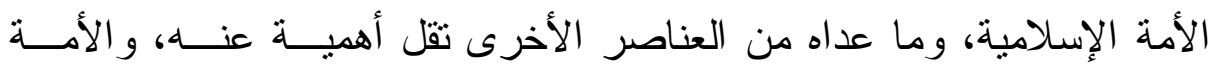

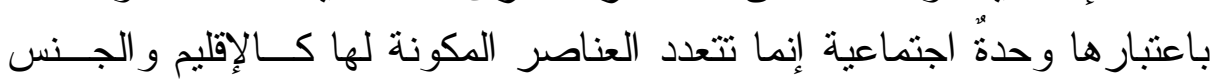

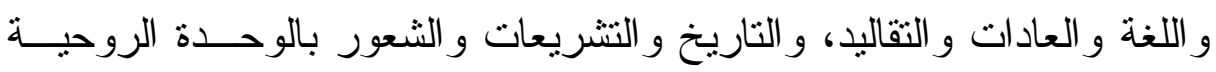

- وهذه هي الأسس النفسية لبناء وتكوين الأمة، فالدين الإسلامي إنمــا

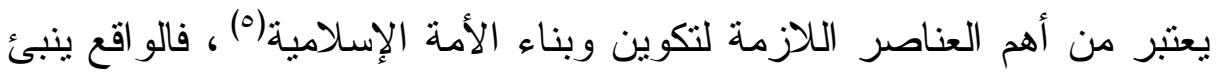

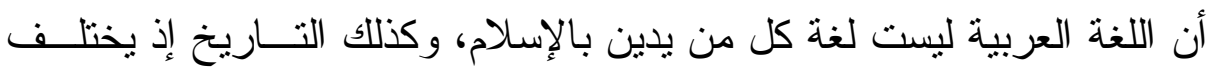
تاريخ كل دولة إسلامية عن غير ها من الدول الإسلامية الأخرى.

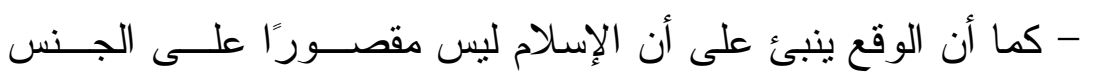

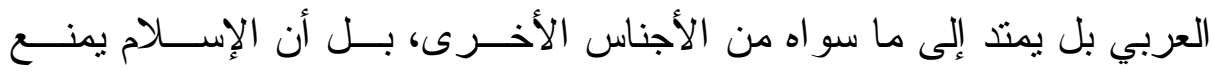

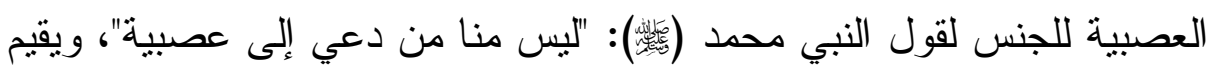

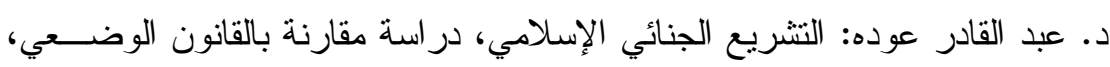

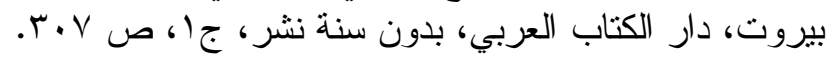

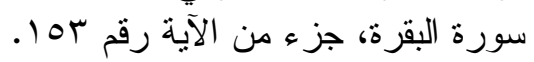

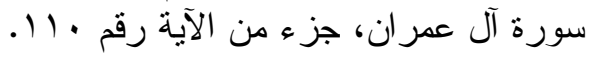

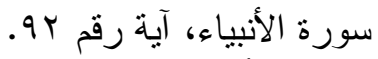

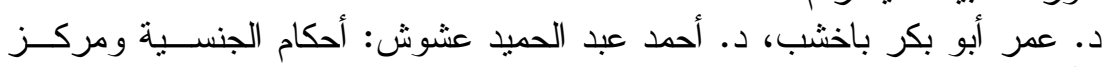

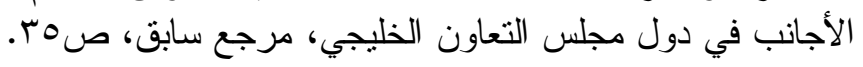


فوقها القاعدة الهامة التي تقول بأن المؤمنون أخوة انطلاقًا من قوله تعـالى:

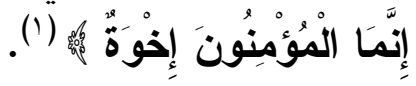

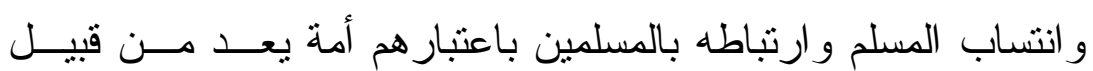

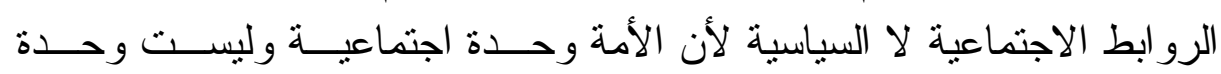

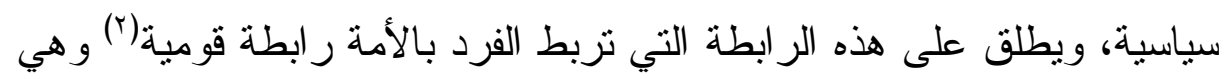

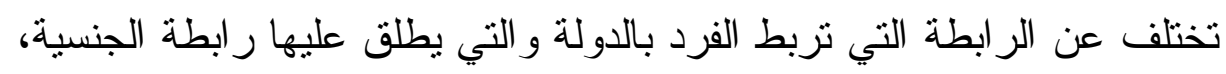

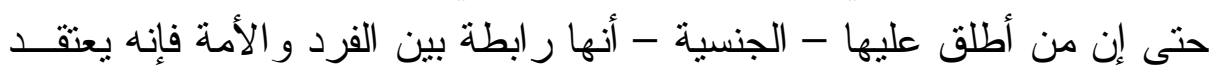

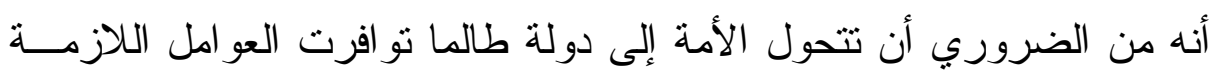

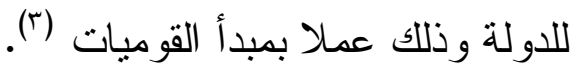

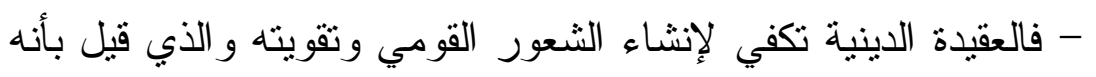

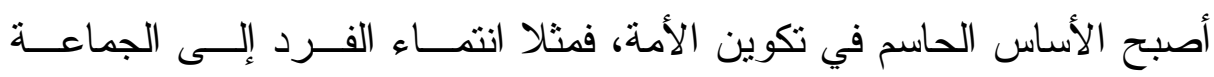

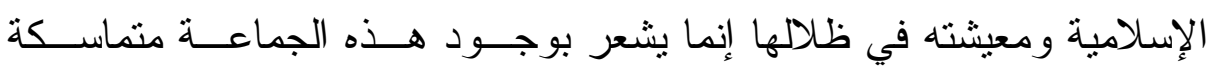

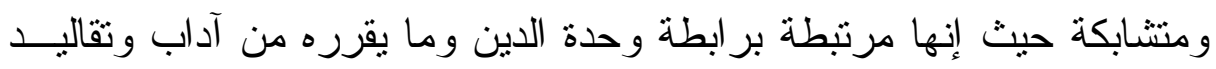

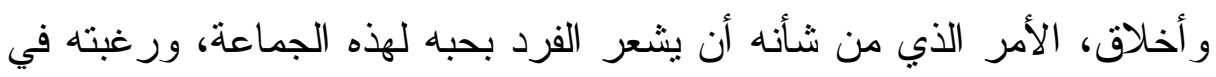

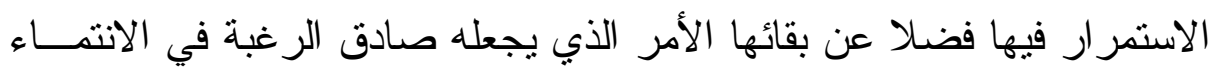

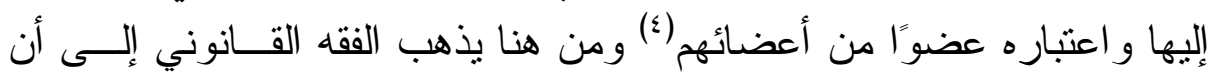

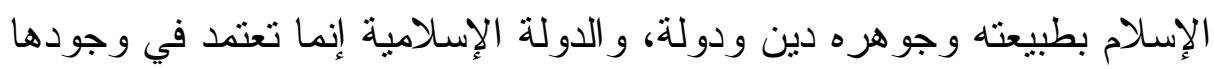

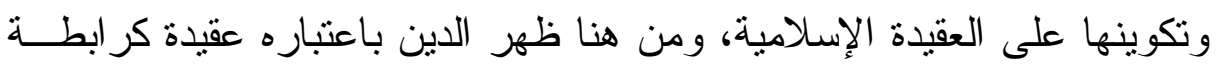

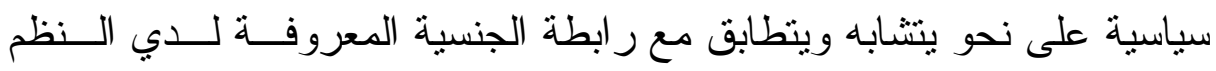

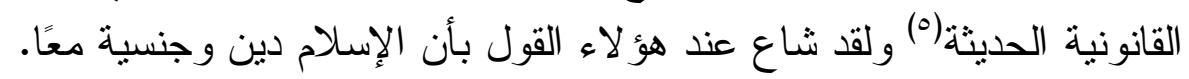

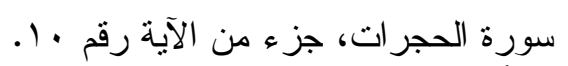

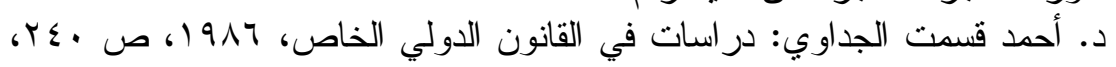

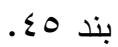

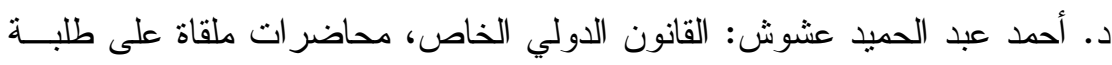

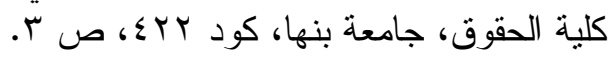

د. عمر أبو بكر باخشب، د. أحمد عبد الحميد عشوش: أحكام الجنســبة ومركـز

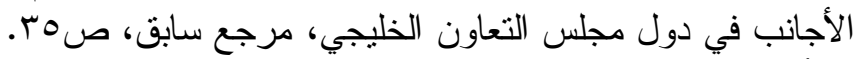

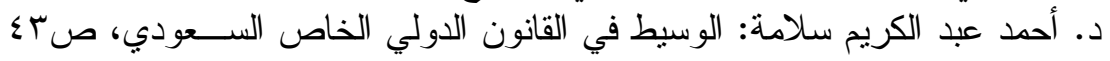

$$
\text { وما بعدها. }
$$

= الطلالة على الجنسية في الفقه الإسلامي والقانون الدولي الخاص 


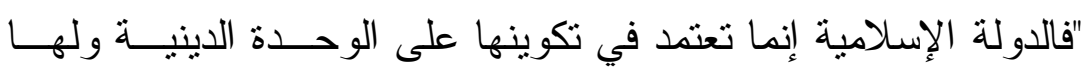

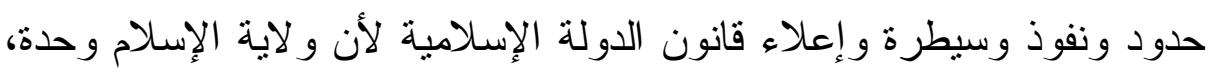

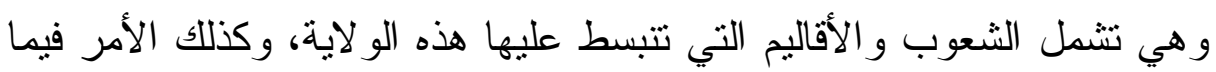

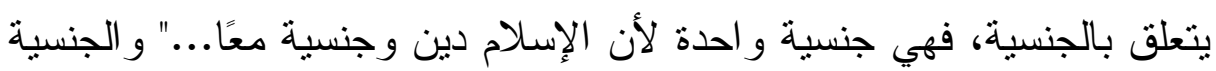

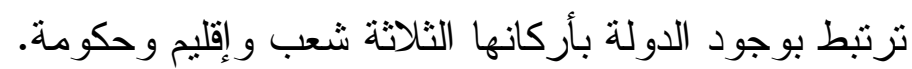

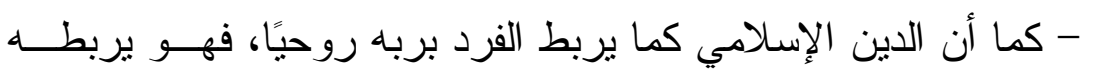

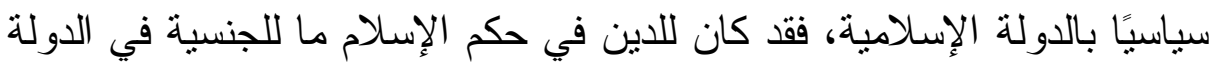

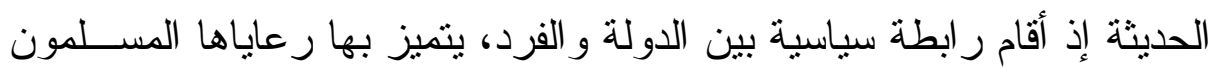
عن غيرهم.

- فالإسلام عقيدة وجنسية في وقت و احد، و المسلمون أينما كانوا أخوة

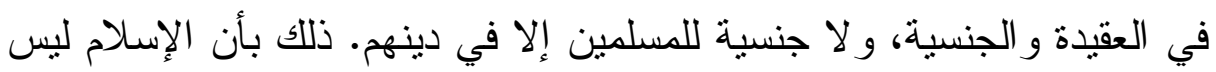

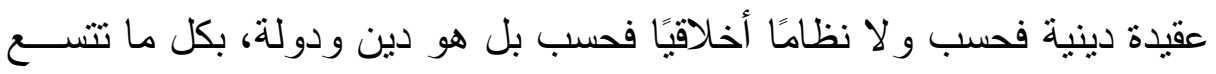

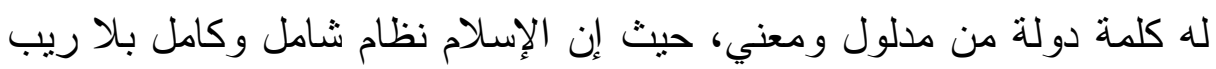

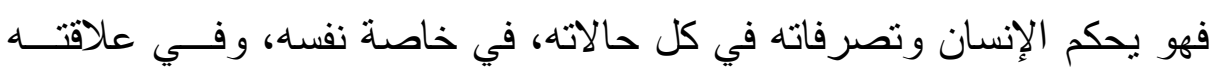

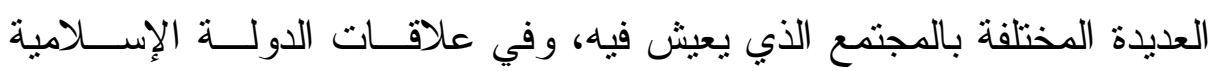

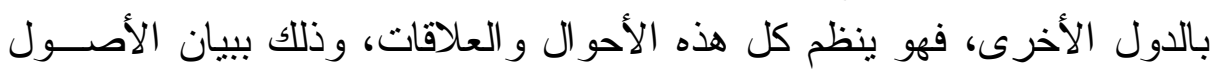
و المبادئ العامة التي تقوم القو اعد و القو انين و النظم التي تحكمها على التى اختلاف التهاف (أنو اعها.. (1)

- فر ابطة التبعية، الرعوية، من بين تلك العلاقات التي أرسـى فيهــا

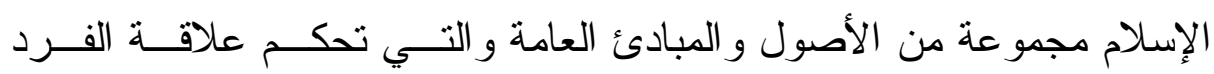

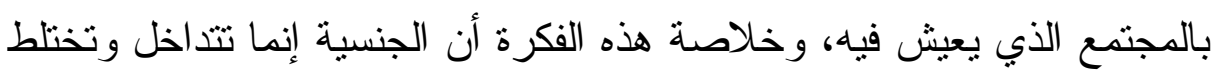

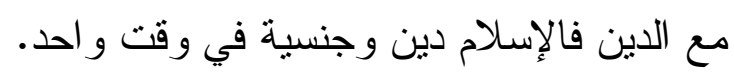

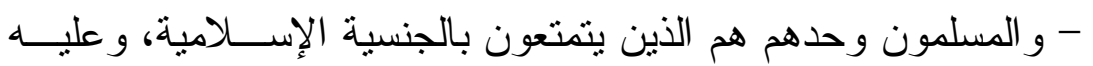

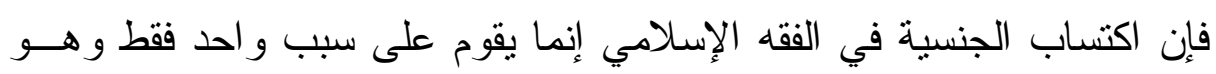

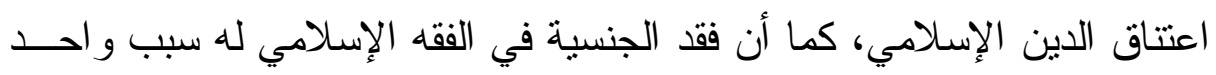

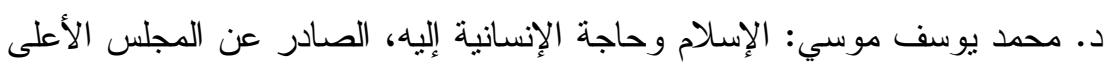

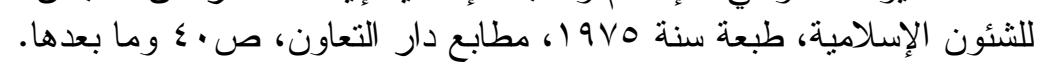


فقط وهو الإزتداد عن الإسلام (')، فإذا عدل المرتد عن ردتــه، وعــاد إلـى الإسلام، إسترد جنسية الدولة الإسلامية من تاريخ فقدها(بام).

- فالأمان الذي يمنح لغير المسلمين بموجب عقد الذمة ليس من شــأنه أن يصبحو ا من رعايا ومواطني دار الإسلام لأن تلاك الرعوية وهذه المو اطنة تبني على العقيدة وهي غير متو افرة في حقهم(r)، ودليل ذلك أنهم لا يتمتعــون

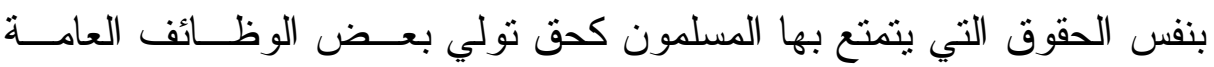

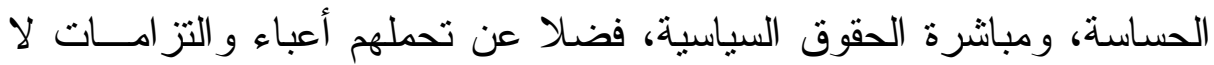
يتحملها المسلمون كأداء الجزية منلا كما أنهم غير مطالبين بالعديد من الأمور،

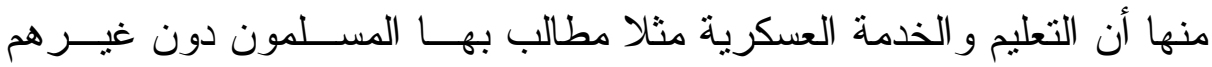

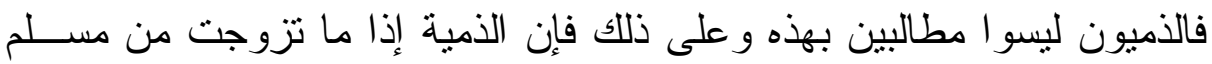
فإنه لا أثز لهذا الزو اج على دخولها في تبعية الزو ج وتمتعها بر عويته طالمــا أنها لم تعتنق الإسلام، فتظل على جنسيتها الأجنبية، و الأو لاد الصغار قانونه

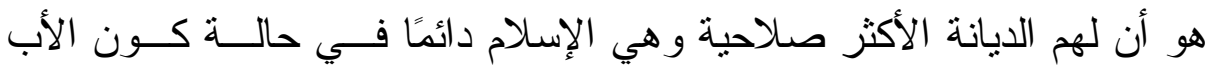
مسلم، فإنهم يتبعونه، و الأم إذا ما كانت من أهل الكتاب "ذمية"، وتزوجت مــن الإنـ

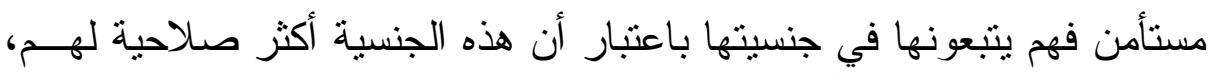

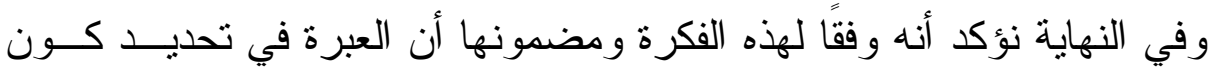
الثخص أو الضنابط الذي تبني عليه الجنسية بحمل جنسية الدولة من عدمه هي كونه معتقاً الإسلام عقيدة أو لا، فمن يعتتق الإسـلام فهو من حملــة الجنســية الإسلامية و إلا فولاه

- فضلاً على أن المادة الخامسة من قانون الجنسية المصرية قد نصى

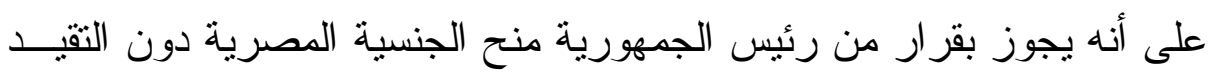
بالثروط المبنية في المادة السابقة من هذا القانون لكل أجنبي يــؤدي لمصــر خدمات جليلة وكذلك لرؤساء الطو ائف الدينية المصرية".

محمد بن محمد الغز الي أبو حامد: الوسيط في المذهب، تحقيــق : أحمـــــ محمــود

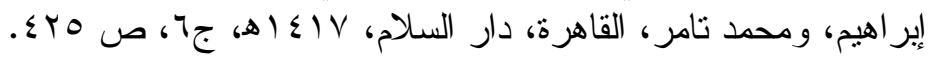

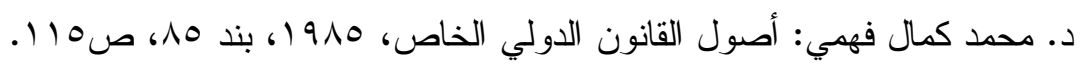

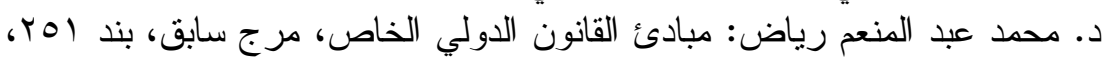
ص 9. 
- - ويلاحظ في هذه الحالة أن الأجنبي يعفي من الثروط المطلوبة للتجنس

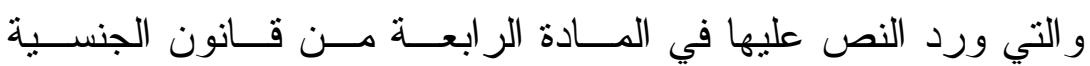
المصرية (') - (الني ورد

- ومصر بلد التسامح و الحرية الدينية، فإلى جانب من يعتتقون الإســلام

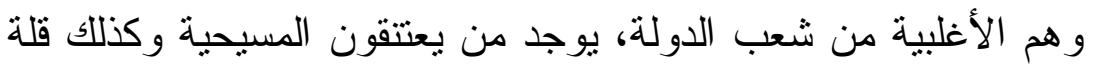
من يدينون باليهودية.

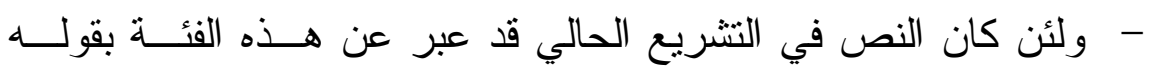

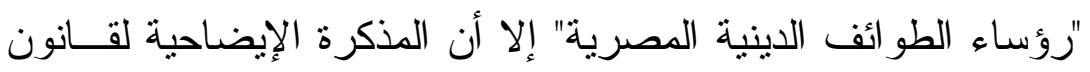
الجنسية المصرية قد زادت على هذا التعبير وصفين:رؤساء الطو ائف الدينية "العاملين في مصر".

الطو ائف الدينية غير الإسلامية "المنظمة شئونها قانوناً" - موالخلاصة أن اكتساب الجنسية المصرية بموجب المادة الخامسة يتسم

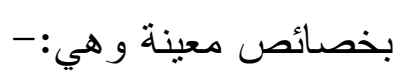

1- - أن اكتساب الجنسية المصرية هو بمثابة منحة أو عطية تقدم كمكافــأة لشخص أجنبي تقديرًا من الدولة لما يحمله من صفة دينية.

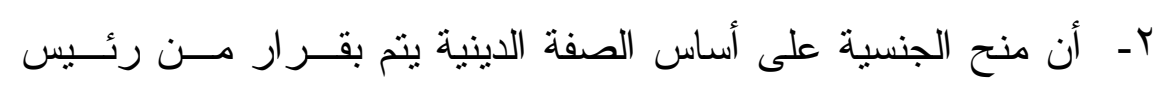
الجمهورية، عكس سائر حالات الجنسية المكتسبة حيث يتعين صدور

$$
\text { قرار من وزير الداخلية. }
$$

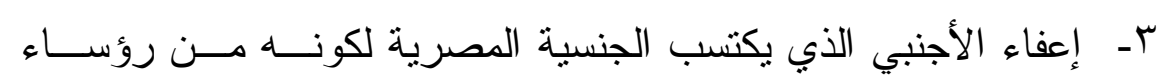

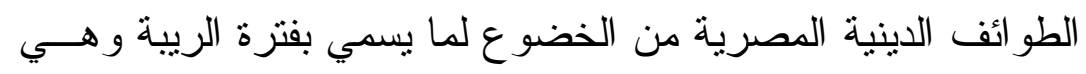

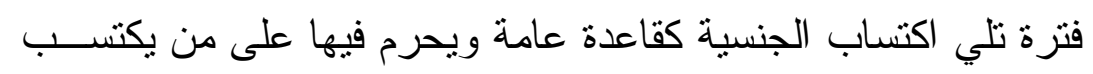

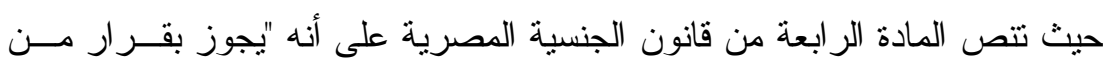

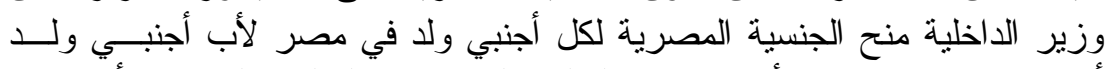

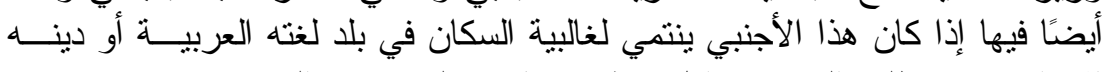

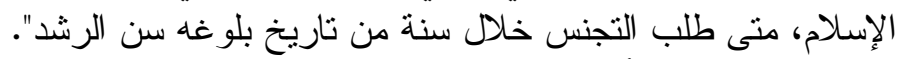

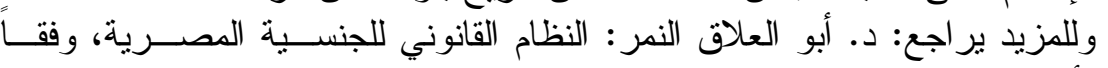

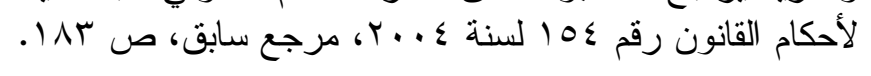


الجنسية من التمتع بمباشرة الحقوق السياسية قبـلـل انقضـــاء خمـسس

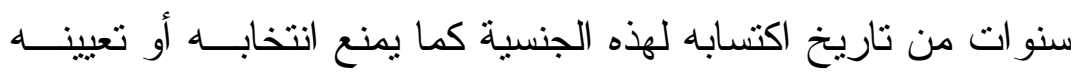

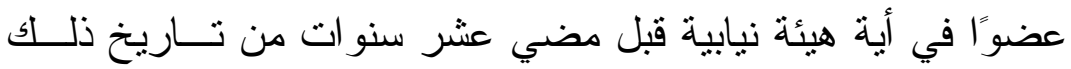

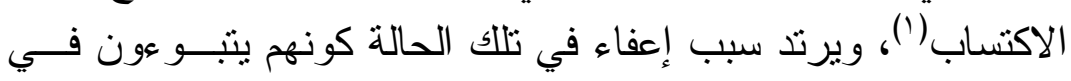
المجتمع الوطني مكانة تنتافي مع حرمانهم من حقوق يتمتع بها أفر اد الطائفة التي يقومون برئاستها (؟).

\section{الفرع الثشني}

\section{وجود البنسية في الفقه الإسلامي وارقباطها بجانب الشريعة}

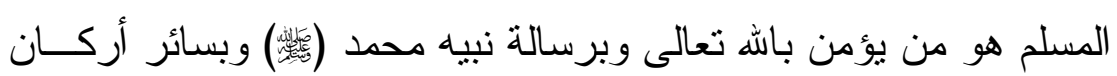
الإيمان ثم يؤدي أركان العبادات.

و الناظر في مضمون هذه الفكرة وما تتنهي إليه يتضح له أن أصــحابها

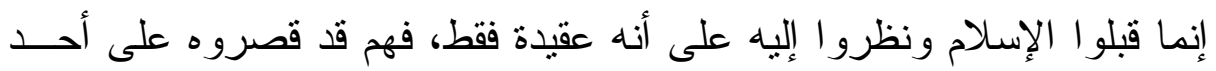

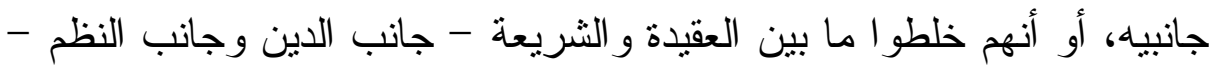

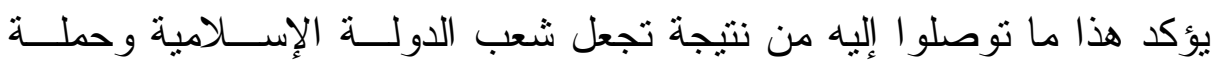

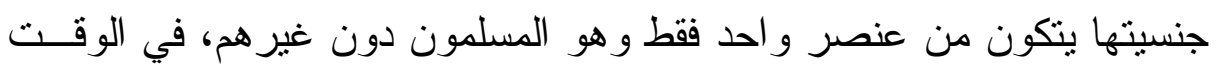

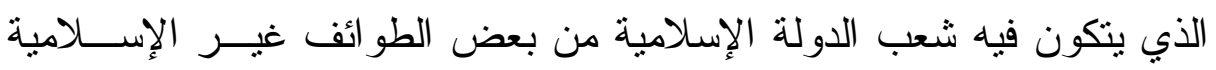

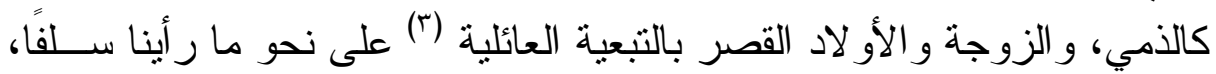
و أكدت ذلك النصوص ولزو و الآر اء الفقهية.

- كما يمكن القول بأن هؤلاء قد حكمو ا على المسلمين بأن يظلاو أمســة

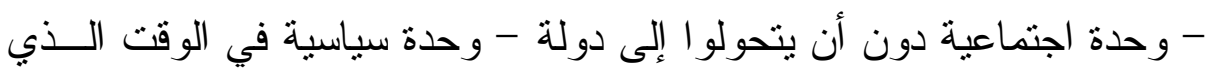

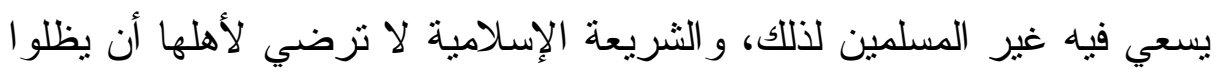
وحدة اجتماعية فقط و إنما تدعوهم إلى التحول إلى تتظيم سياسي، أي إلى دولة الإلة

راجع مو من قانون الجنسية المصري.

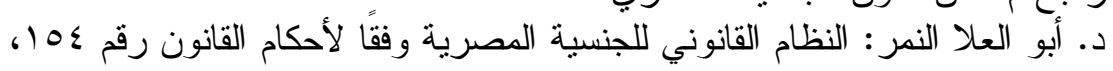

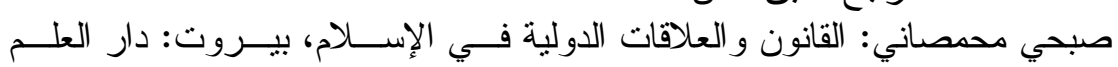
للملايين، كYT ال، ص10.

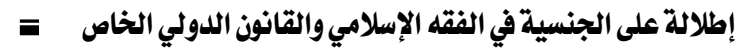


لأن أغر اض الإسلام لا تتحقق كما ينبغي وأحكامه لا تتفذ كما يجب إلا بقيـام هذا التتظيم السياسي للمسلمين (').

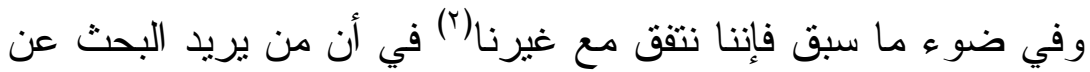

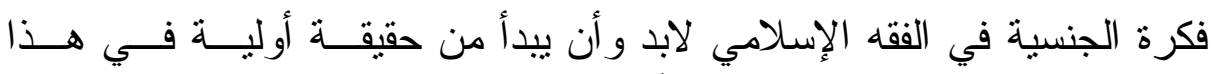

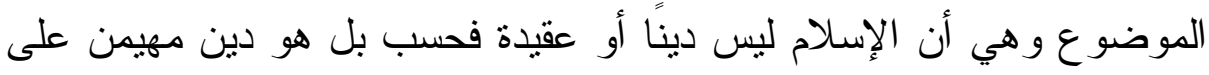

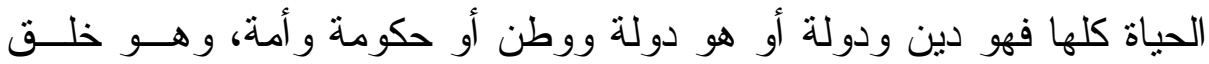

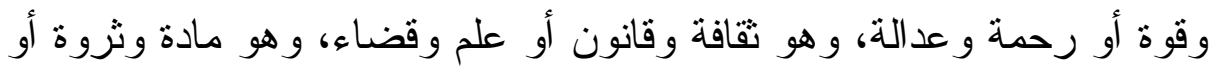

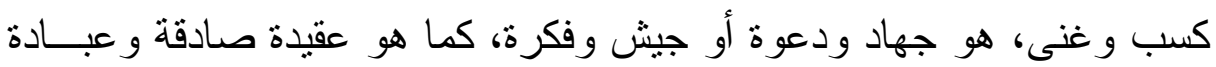

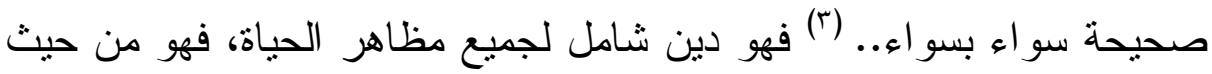

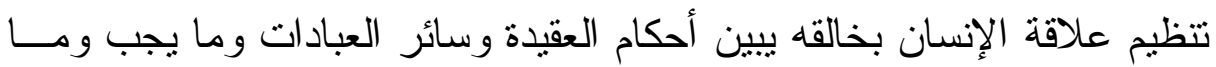

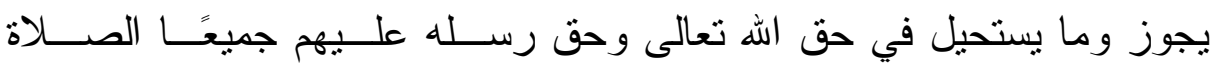

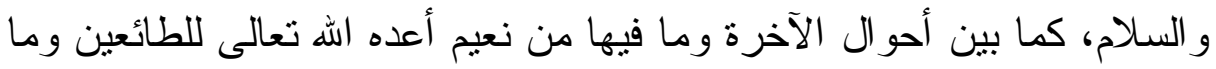

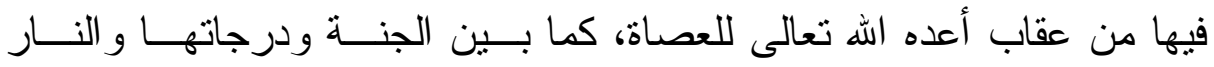

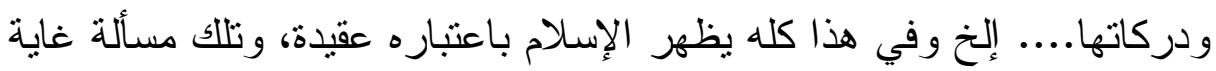

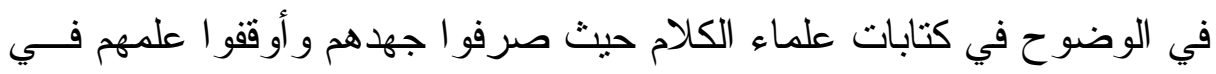
الحصر على بيانها وتوضيحها لكل معتبر .

- و وأما من حيث تتظيم الإسلام لشئون وحياة الأفر اد و الجماعات فنجد

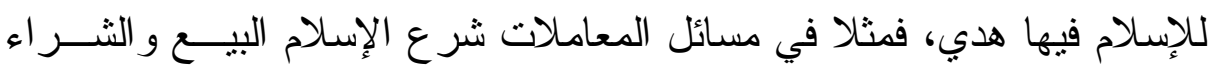

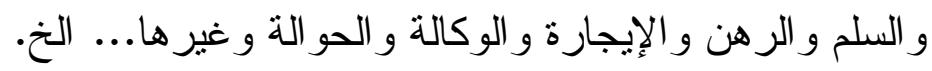

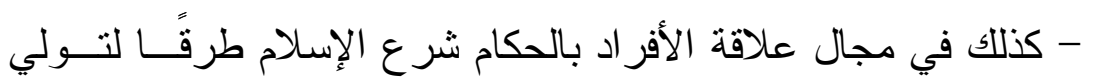

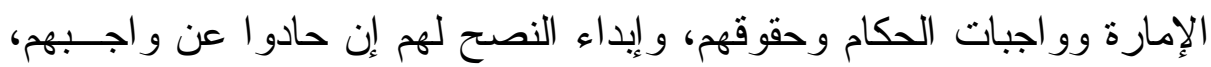

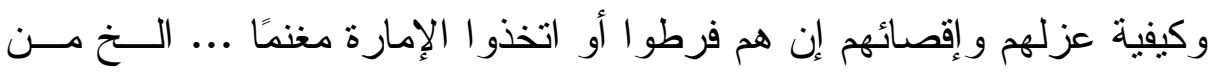

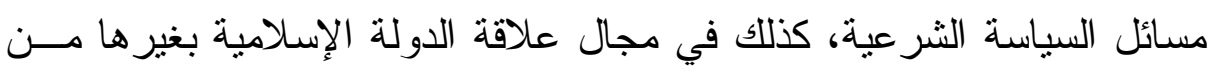

د. عبد الكريم زيدان: أحكام الذميين و المستأمنين في دار الإسلام، رسالة دكتــور اه،

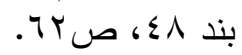
الأستاذ/ أحمد طه السنوسي: فكرة الجنسية في التتريع الإسلامي المقارن، مرجـع

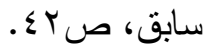

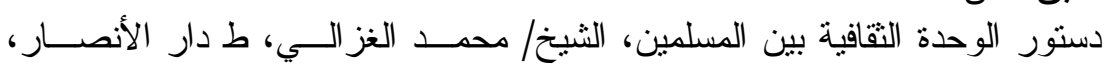

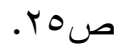


الدول في حالتي السلم و الحرب نجد للإسلام فيها تشريع يظهر من خلاله مدي عظمة هذا الإسلام وتتظيمه لذلك قبل غيره من المو اثيق الدولية. - وهذا التنظيم و إن كان ظاهرًا معروفًا في العديد من جو انبه، إلا أنه إنه

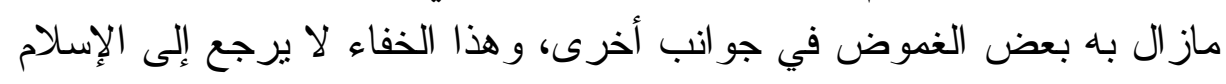
ولا يد له فيه أكثر ما يرجع إلى الباحثين و الكتاب.

- وفي مجال علاقة الأفر اد بالدولة التي يتمتعون بحمايتها و العيش في

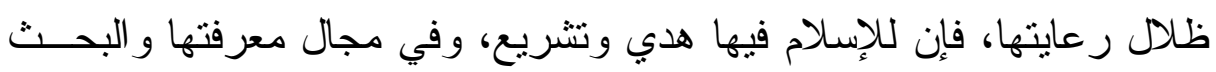

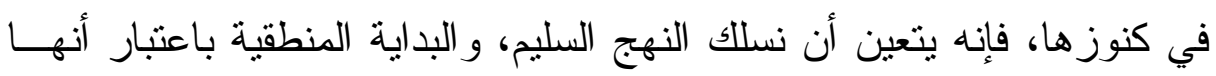
تتعلق بجانب النظم، الثريعة، لا جانب النه الدين و العقيدة(') لأن الثريعة كما تتظم

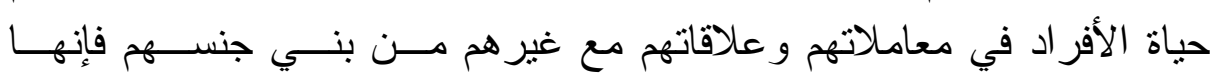

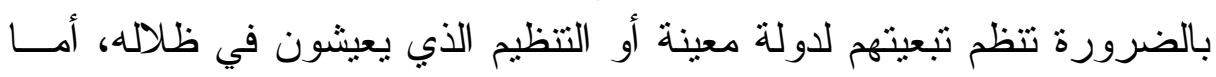

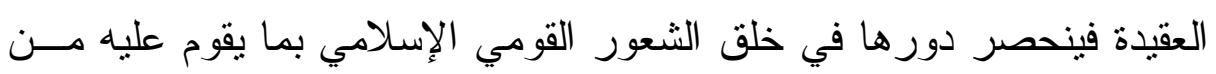

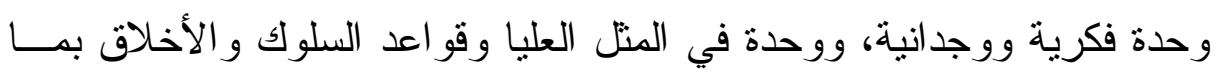
يجعل الجماعة وحدة متماسكة ومتشابكة في المشاعر و الاهتمامات، الأمر الذي ودي لئي

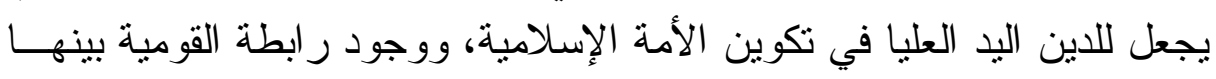
وبين الأفر اد المكونين لها.

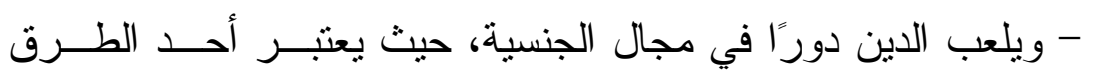

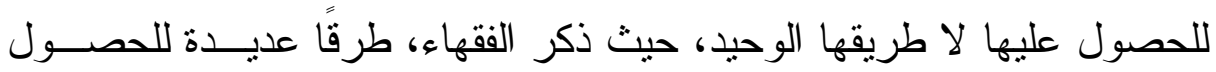

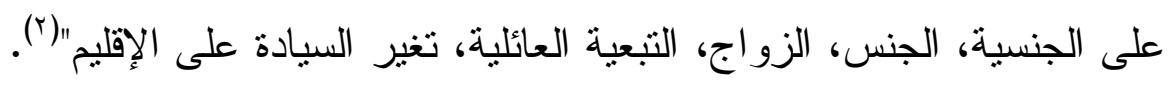

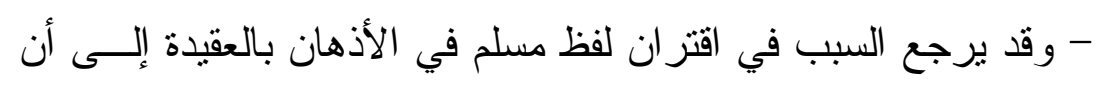

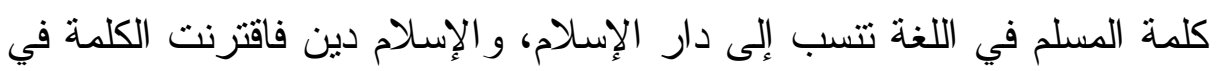

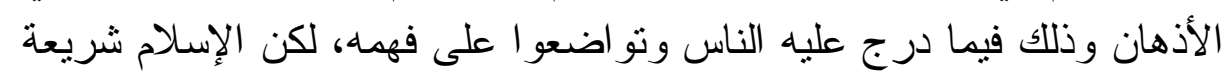

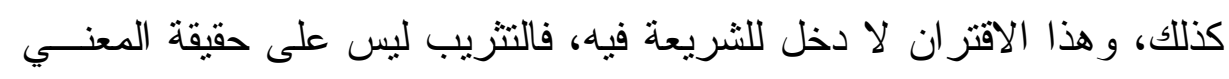
و لا على حقيقة الكلمة، و إنما في عدم التدقيق في فهم مر ادهما.

د. عمر أبو بكر، د. أحمد عبد الحميد عشوش، أحكام الجنسية ومركز الأجانب في صي

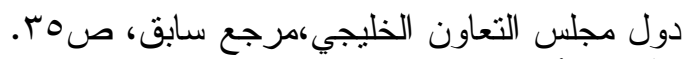
الأستاذ/ أحمد طه السنوسي، فكرة الجنسية في التشريع الإسلامي المقارن، مرجـع

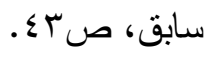


- وخلاصة هذه الفكرة تتبلور في أن فكرة الجنسية في الفقه الإسلامي

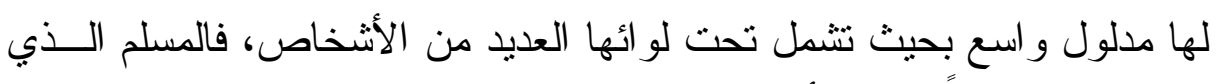

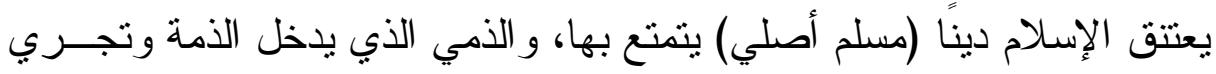

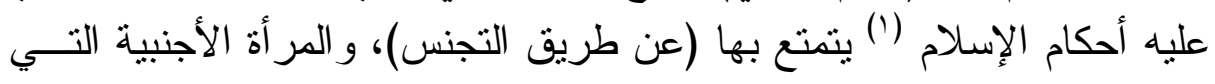

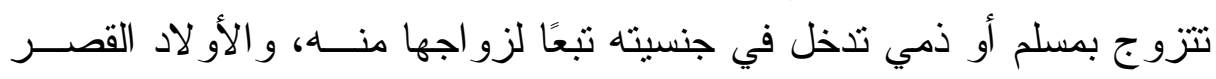

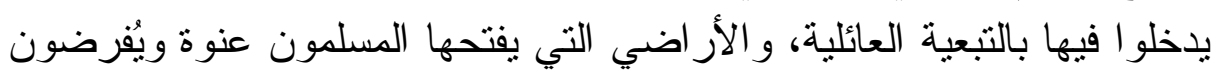

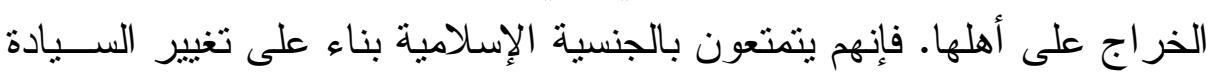
على الإقليم.

- ومما يؤكد وجود فكرة الجنسية في الفقه الإســلامي أن مفترضــات

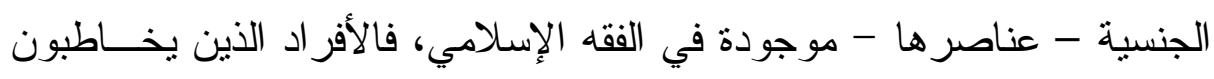

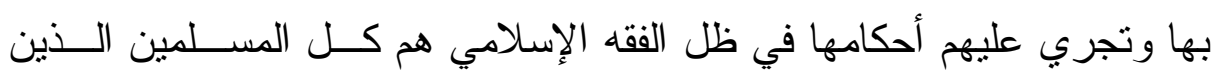

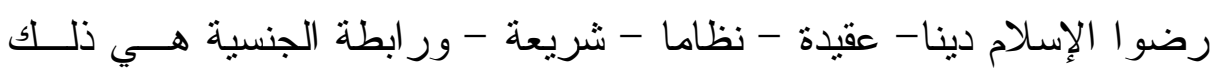

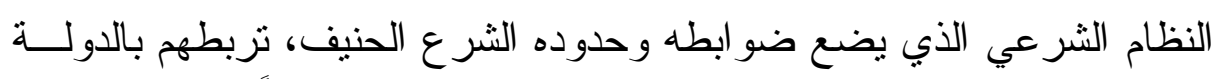

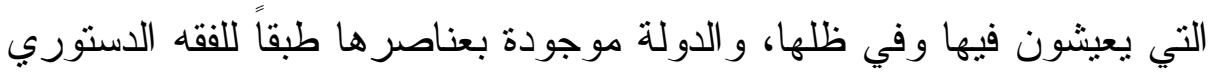

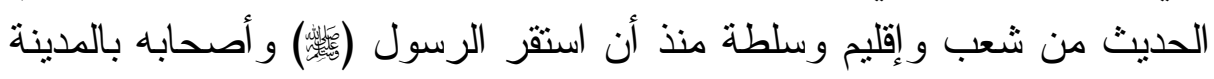

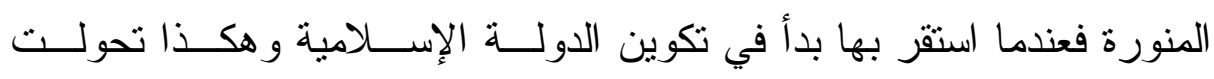

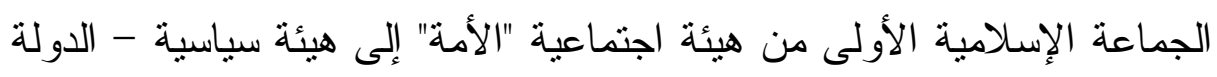

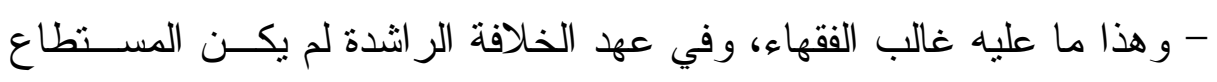

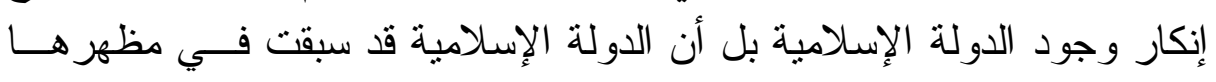

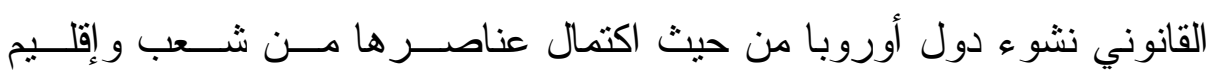

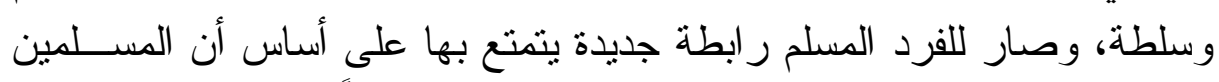

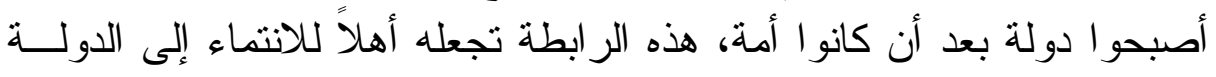

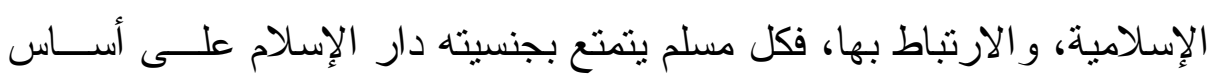
تو افر الرعوية الإسلامية فيه.

عبد الكريم زيدان: أحكام الذميين و المستأمنين في دار الإسلام، بيــروت، الثـــركة

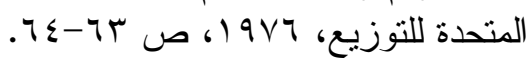

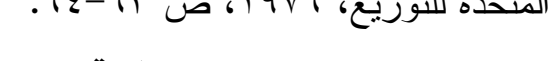




\section{البمش الرابة}

\section{تقدير النقه الإسلامهي لامنسية}

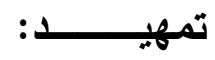

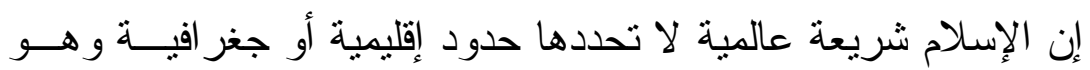

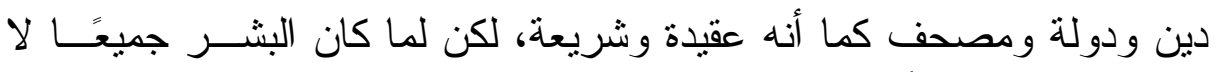

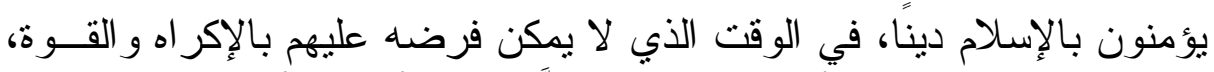

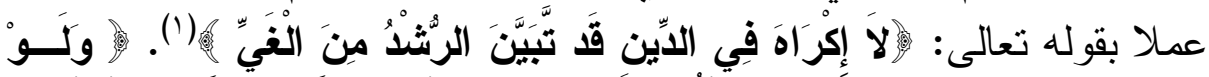

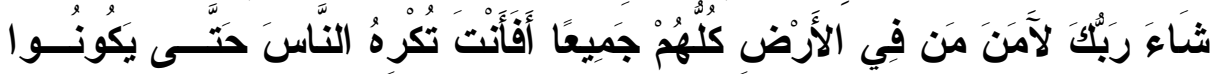

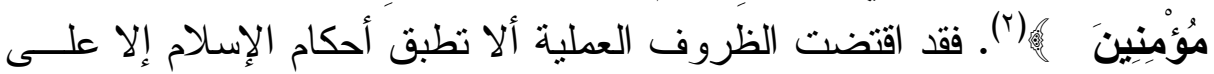

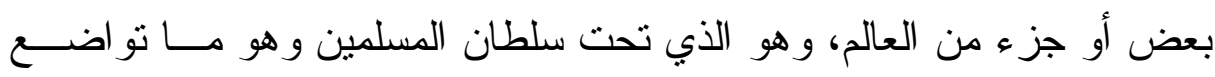

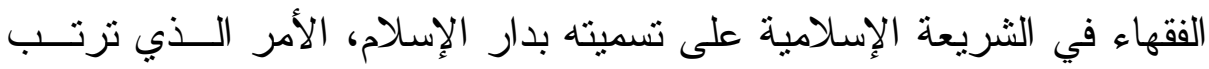

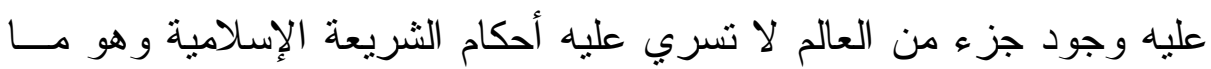

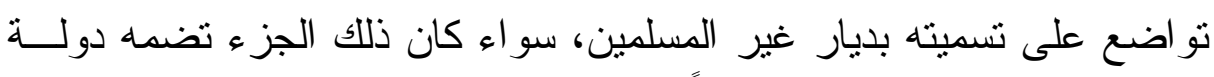
واحدة أو ينقسم إلى عدة دول، وفقًا للتنظيمات الحديثة.

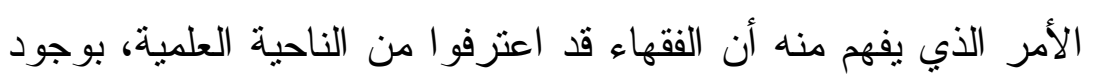

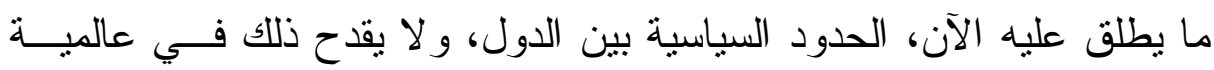

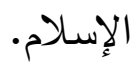

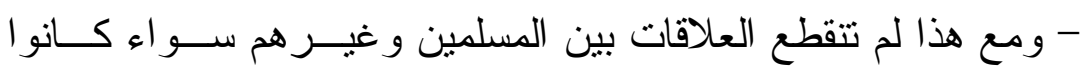
المقيمين معهم في دار الإسلام أو خارج ديار الإسلام.

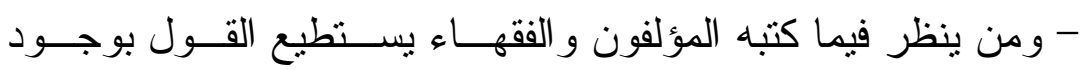

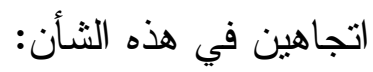
أحدها: ينكر وجود - أو معرفة الفقه الإسلامي - فكرة الجنسية.

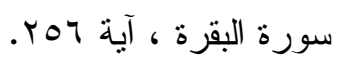

سورة يونس، آية 99.

إطلالة على الجنسية في النقه الإسلامي والقانوز الدولي الخاص = 


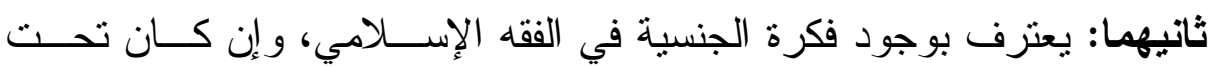

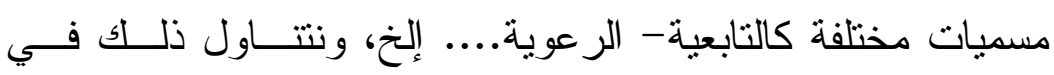
مطلبين وذللك على النحو التالي: المطلب الأول: الاتجاه المنكر لوجود الجنسية في الفقه الإسلامي. المطلب الثاني: الاتجاه المؤيد لوجود الجنسية في الفقه الإسلامي.

\section{المطلب الأول}

\section{الاتجاه المنكر لوجود البنسية في الفقه الإسلامي}

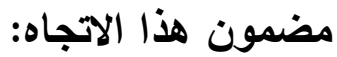

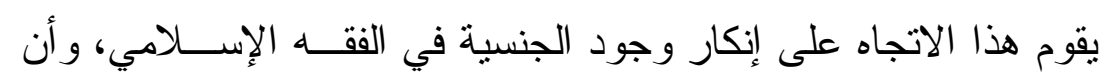

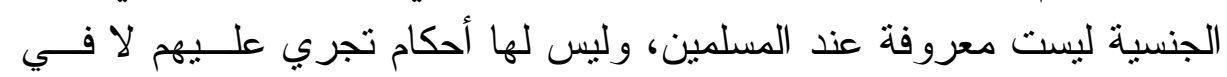

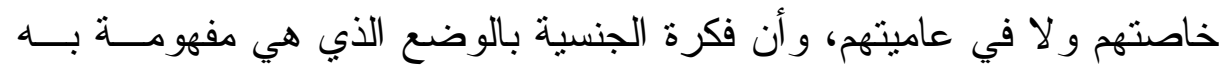

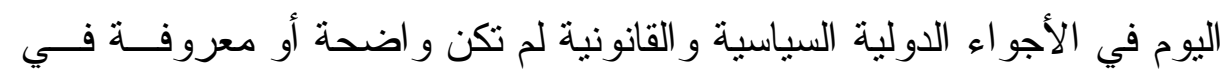

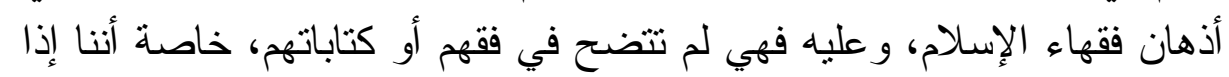

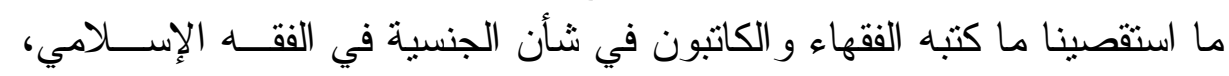
لوجدنا أن الثريعة الإسلامية تخلط ما بين الدين و الجنساء ولكية.

- و العقيدة الدينية لا دخل لها في تكوين الجنسية، و لا في التشريع لها،

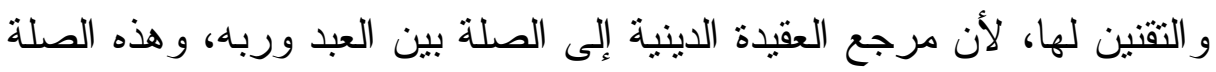

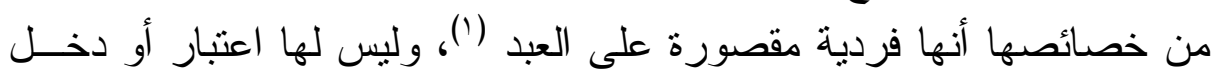
في نظام الجنسية الذي يتعلق بكيان الدولة و علاقتها بر عاياها. طائفة من الكتابات تؤيد هذا الاتجاه:

سوف يظهر من خلال استعر اضنا لما كتبه بعض الفقهاء و الكتاب بأن

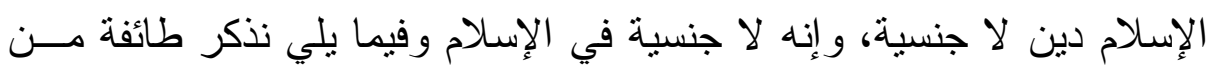

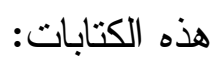

صبحي محمصاني: القانون و العلاقات الدولية في الإسلام، مرجع سـابق، ص 1 . 
ا - هذا ما تقضي به الثريعة الإسلامية على اختلاف مذاهبها لا جنسية في الإسلام و لا امتياز في الحقوق بين مسلم ومسلم" (').

r - "إن الإسلام دين لا جنسية، وليس في الإسلام معني الجنسية المعروفــة الآن، نعم إن للإسلام دولة، و إن كان هو في نفسه ديناً لا جنسية" (r). "- " "يجب أن يلاحظ هنا أن الإسلام يعتبر في آن و احد عقبدة وجنسية أينما كانو أخوة في العقيدة و الجنسية، غير أن أحكام الإسلام الدنيوية لا نفاذ لها في غير دار الإسـلام (r).

ع - لا جنسية للمسلمين إلا في دينهم، ولذلك يعد تعدد الحكام عليهم كتعـدد الرؤساء في قبيلة واحدة، أو تعدد السلاطين في جيش و احد مع اختلاف

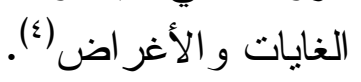

0ـ "وفي الثرق كانت الديانة في الأصل - مصدر - المقياس فــي تمبيـز ديانة الوطنيين، و الإسلام رفض التسليم بالجنسيات المتعددة للشخص في

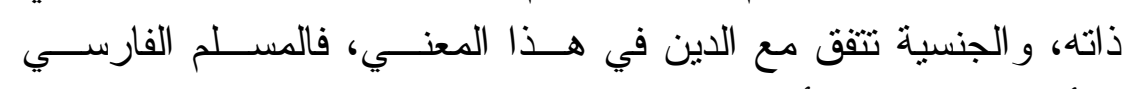

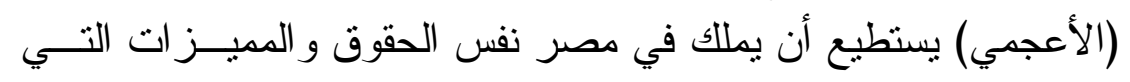
للمسلم المصري....

\section{أدلة هذا الاتجاه: - 2 - ألة}

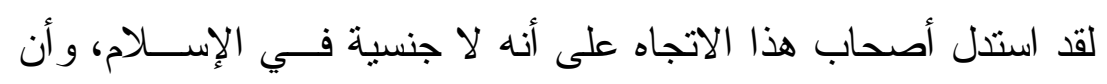

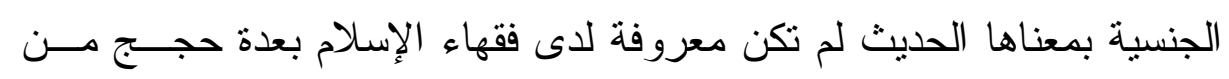
أهمها ما بلي -

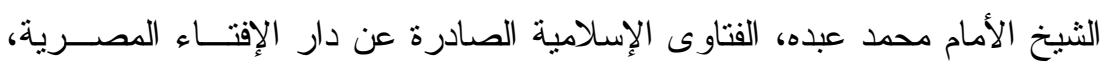

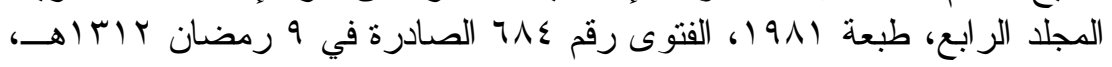

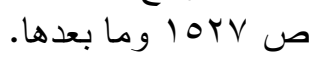

السيد/ محمد رشيد رضا، تفسير المهاء المنار ، الجزء الثاني الطبعة الأولي، مطبحسـة دار

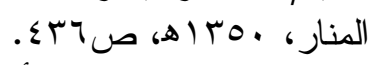

صاحب الفضيلة، الشيخ/ أحمد إير اهيم إبر اهيم، في بحثة حكم الثريعة الإســلامية

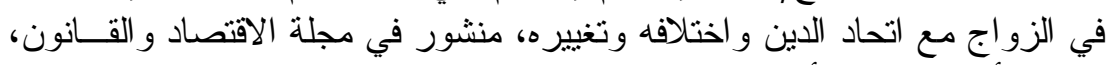

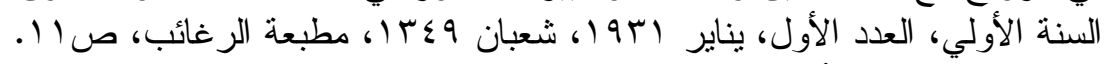

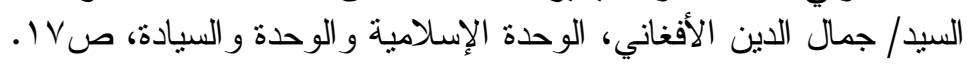


أولا: أن الجنسية في حقيقتها تشبه ما كان بسمي عنــد العــرب بالعصــبية(')،

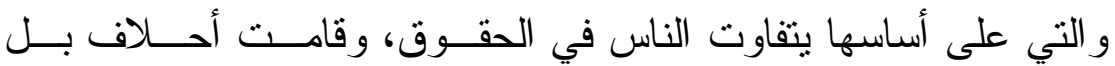

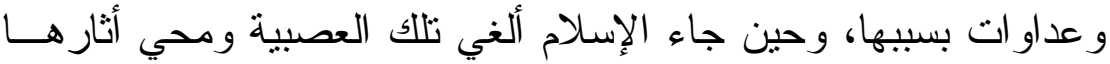

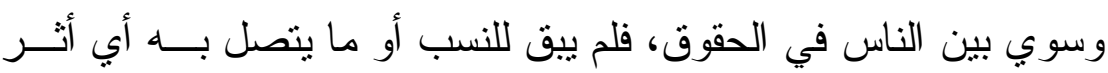

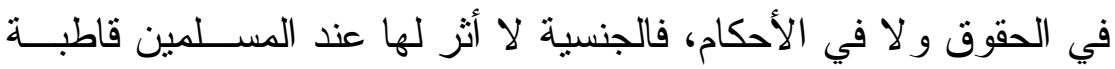

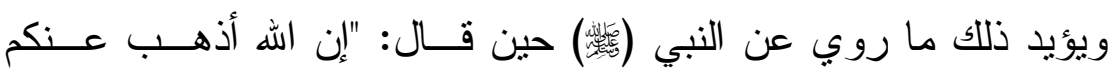

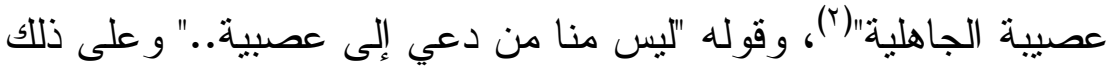

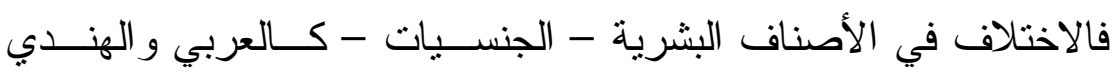

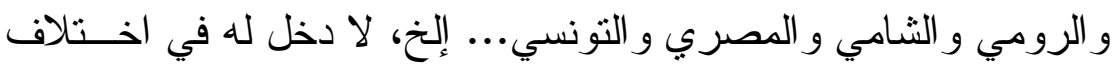

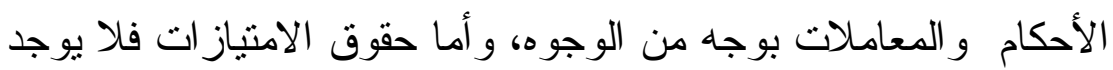

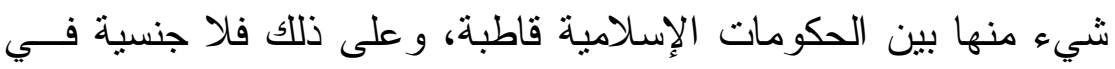
الإسلام، و لا امتياز في الحقوق بين مسلم ومسلم.

ثانيًا: من الأمور المسلمة أن الإسـام دين وشريعة عالمية، جاء للعــالم كلــهـ

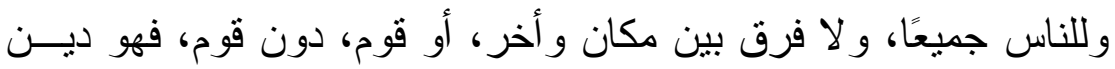

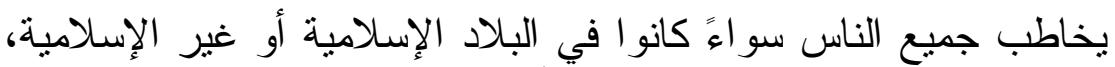

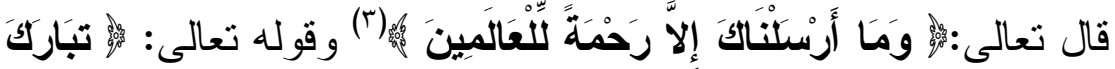

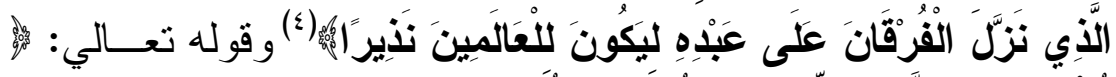

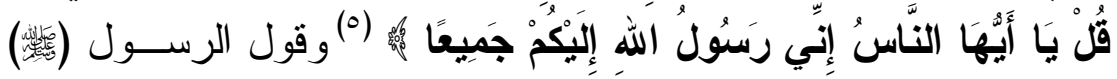

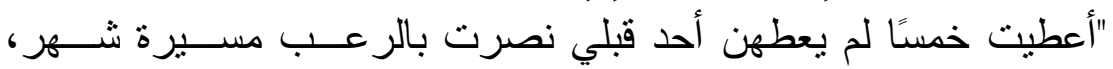

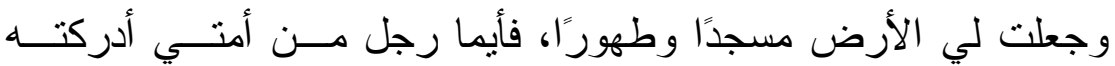

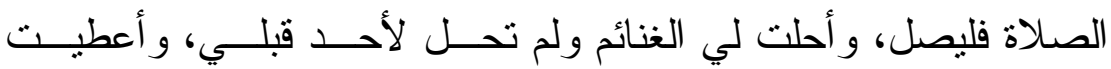

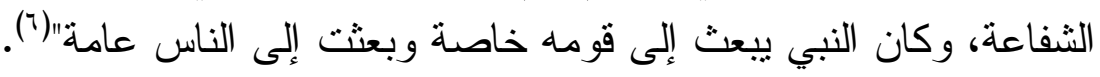

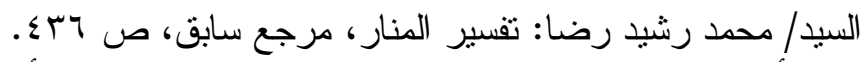

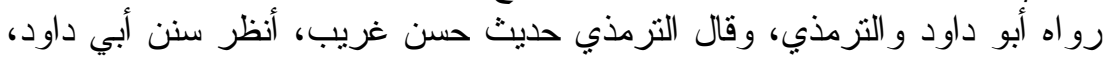

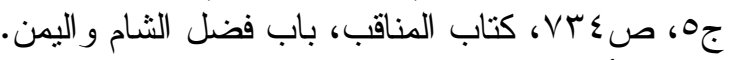

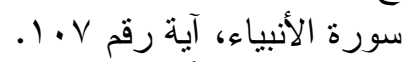

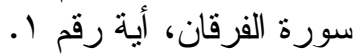

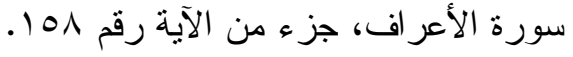

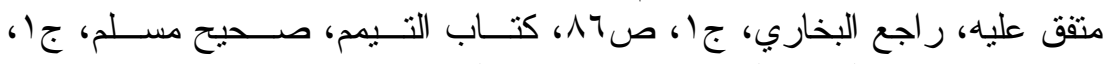

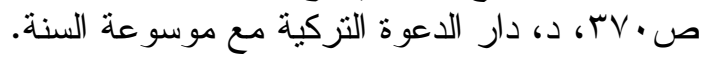


- هذه النصوص وغير ها كثيرة، إنما تؤكد عالمية هذا الــدين وفـي ألـي

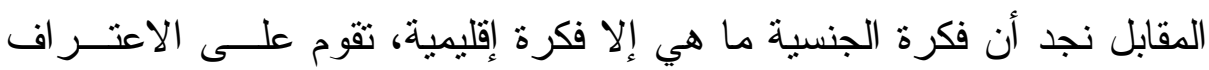

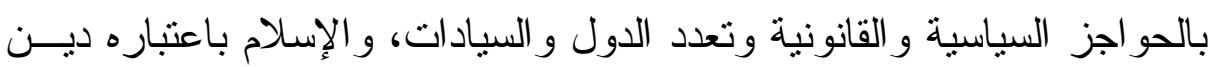

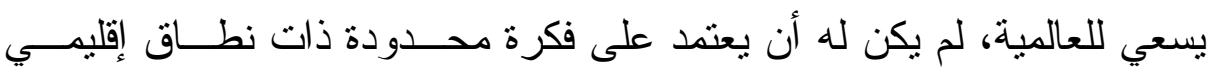

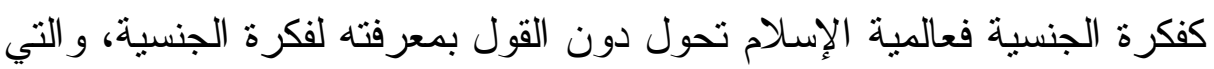

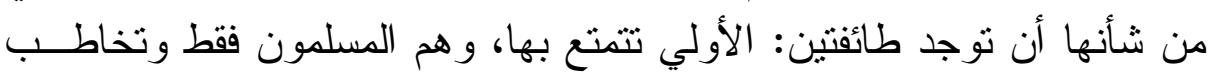

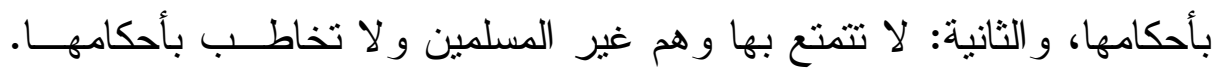

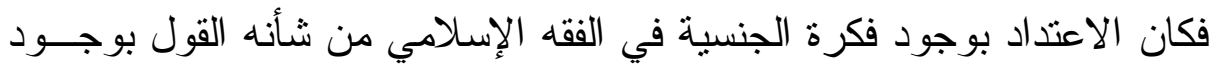

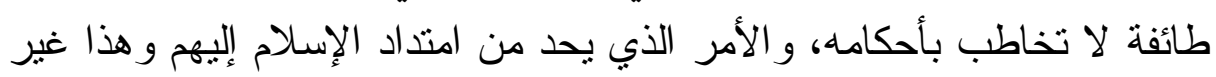
مقبول مع تقرير العالمية لهذا الدين.

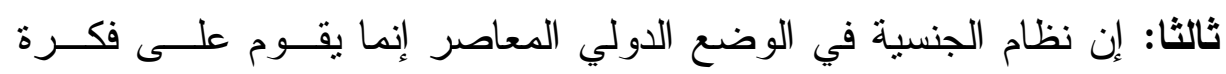

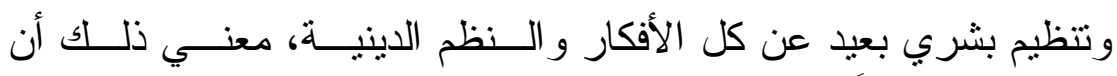

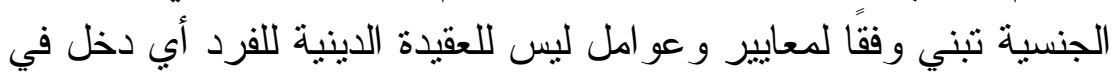

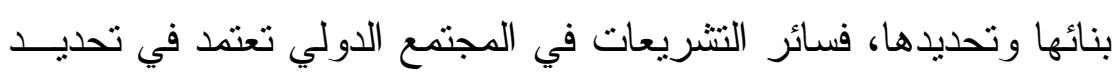

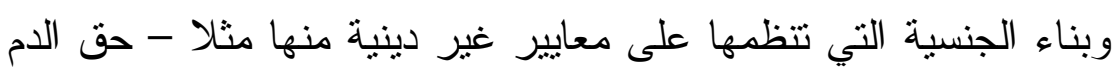

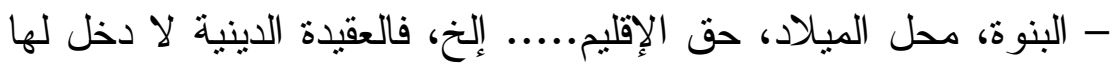

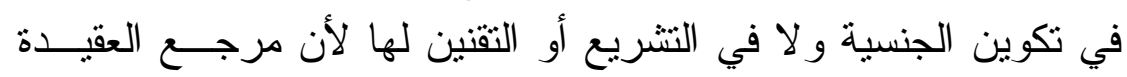

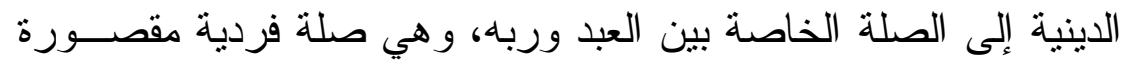

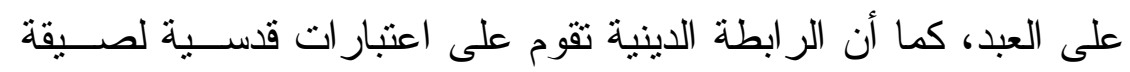

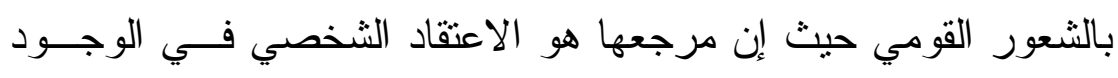
الإلهي، وليس لهذه العقيدة دخل في نظام الجنسية، و الذي يتعلق بكيــان

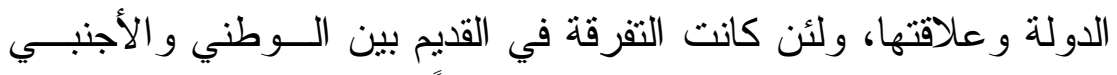

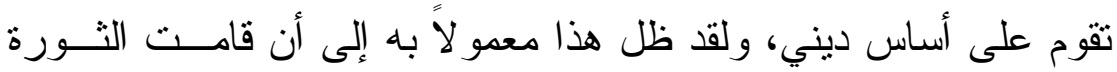

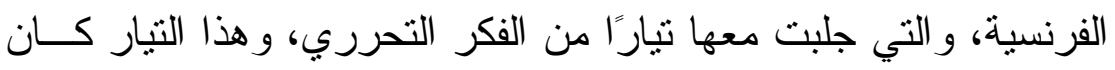

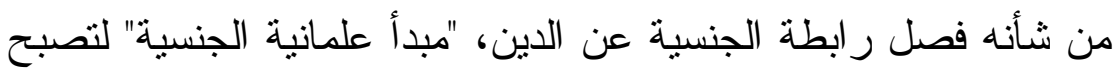

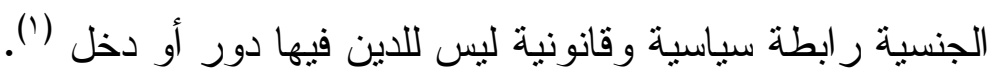

د. أحمد قسمت الجداوي: دراسات في القانون الدولي، مرجع سابق، ص ^؟ ؟، بند 


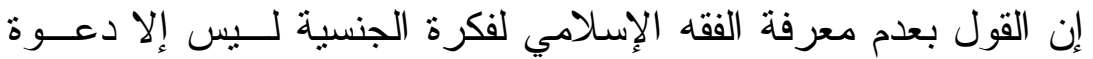

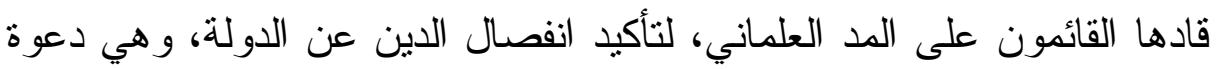

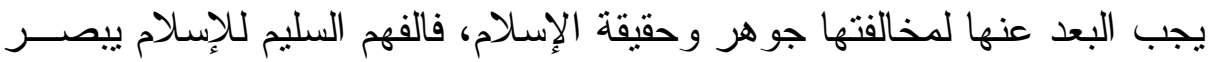

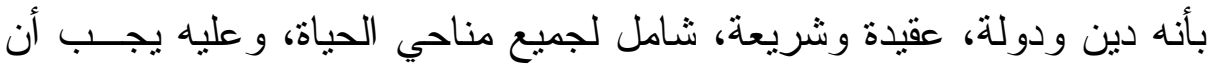

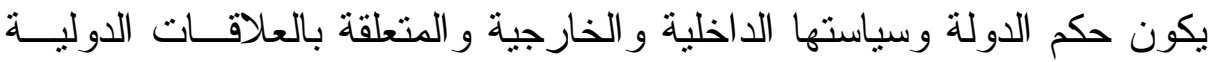

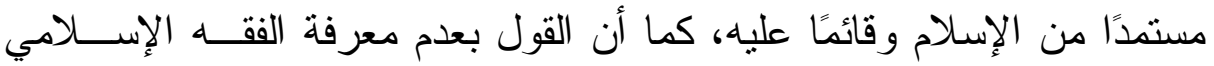

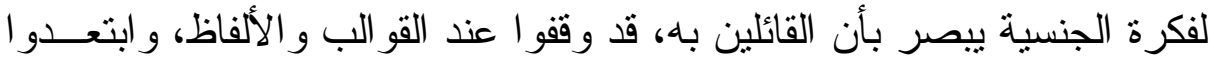

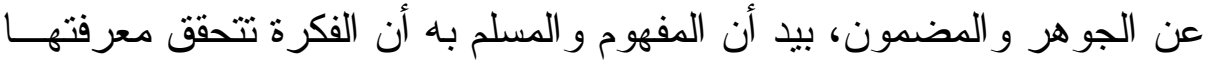

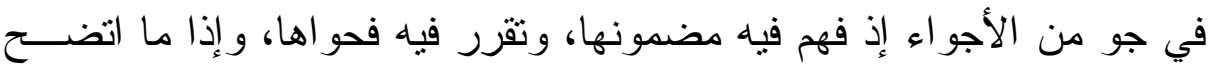
ذللك فلا يهم بعد صبغة اللفظ المستعمل. - ومن المعلوم أن مصطلح الجنسية لم يظهر في الأفق إلا حديثًا، في

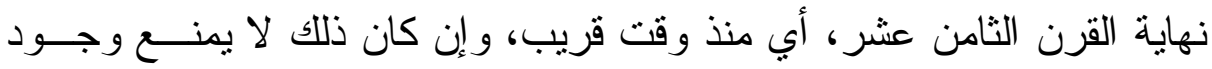
تطبيقات لفكرة الجنسية في الفقه الإسلامي قد وجدت مند منذ زمن بعيد.

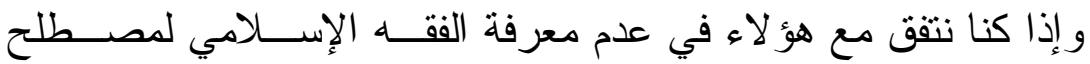

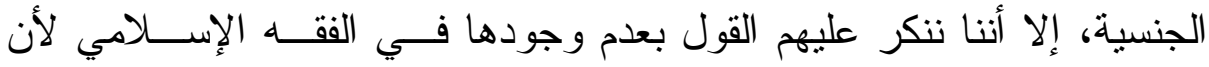

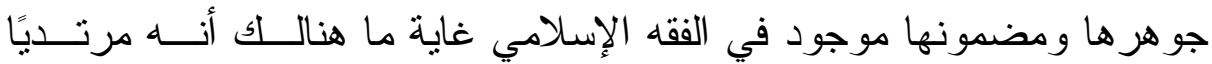

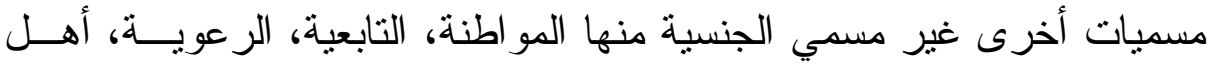

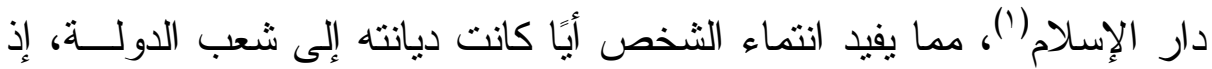
من المعلوم أن الثرع الحنيف حين خاطب الناس في بداية مرحلة النشريع كان

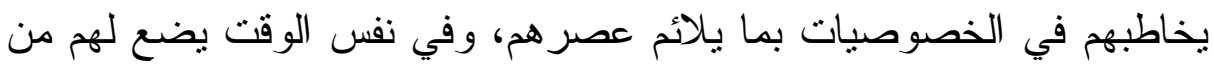
العموميات القو اعد العامة في الأحكام بما سوف يستجد بعد من الأحداث، لأنه

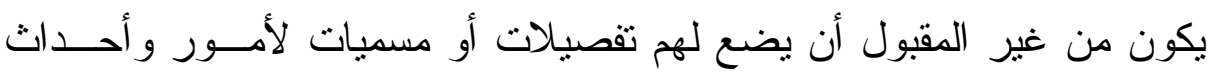

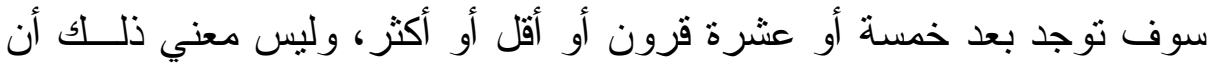

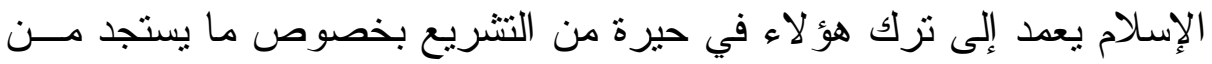

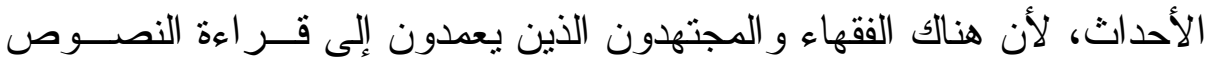

د. أحمد عبد الكريم سلامه: الوسيط في القانون الدولي الخاص السعودي، مرجـع

$$
\text { سابق، ص آ و وما بعدها. }
$$

= =لالة على الجنسية في الفقه الإسلامي والقانون الدولي الخاص 
وفهمها وتعدية أحكامها إلى ما يشبهها من الأحداث و الوقائع طالما أنها اتحدت معها في العلة.

\section{الإلابب الثناني}

\section{الاتباه الإويد لوجود الجنسية في الفقه الإسلامي}

مضمون هذا الاتجاه وتطوره:

يقوم هذا الاتجاه في مجمله - على الاعتر اف بوجود الجنسية من حيث

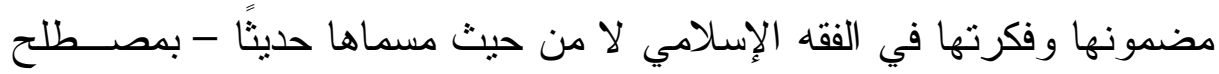

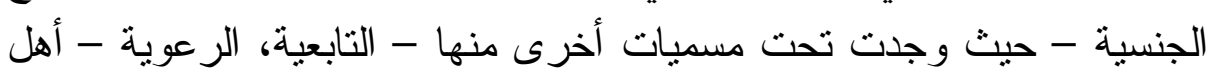
دار الإسلام، حيث إن الدولة الإسلامية قد سبقت غيرهات هات من التنظيمات الحديثة

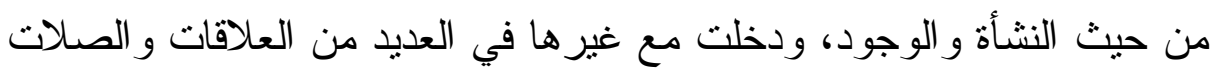

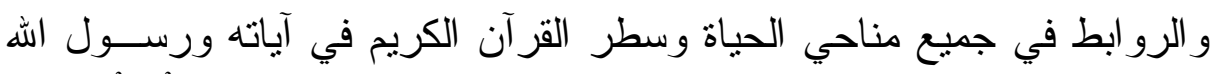

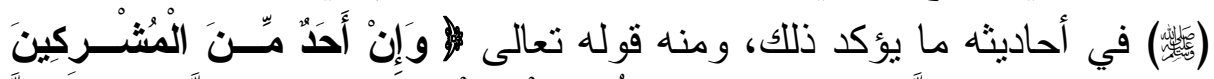

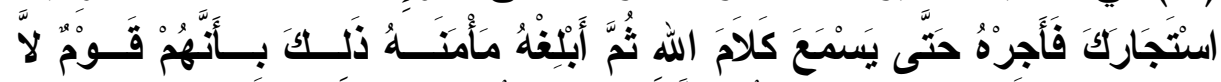

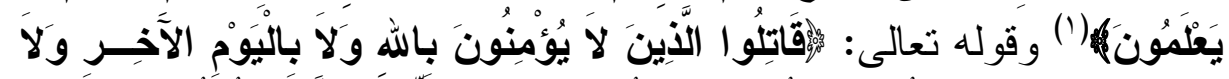

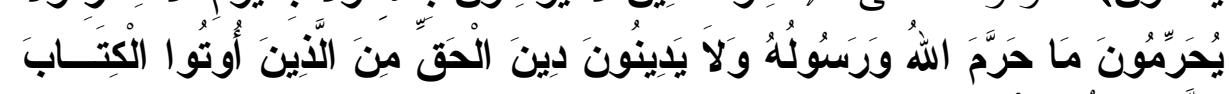

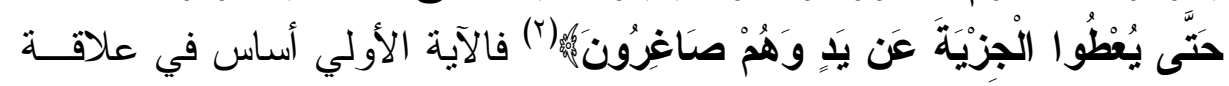

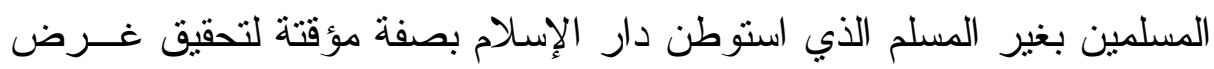

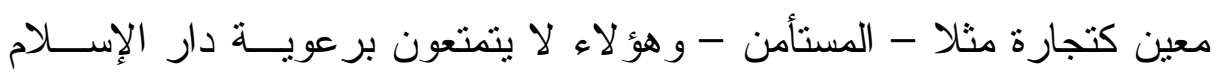

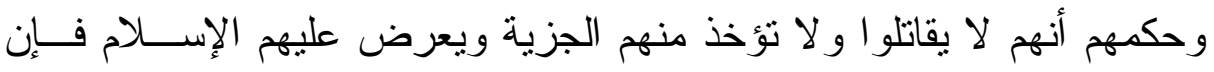

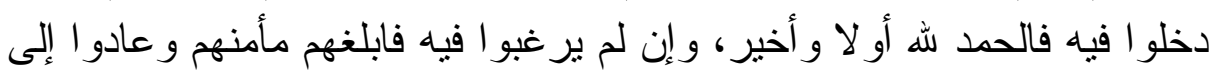
ديار غير المسلمين كما كانو ا"(").

- و الآية الثانية أساس في علاقة المسلمين بغير المسلم الذي أقام بصفة

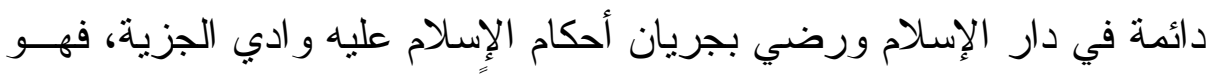

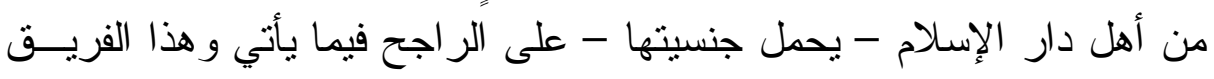

$$
\text { سورة التوبة، آية رقم } 7 .
$$

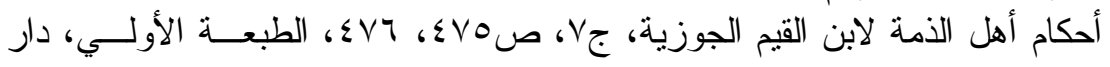

الكتب العلمية، بيروت، لبنان. 
له ما للمسلمين و عليه ما على المسلمين، وفي هذا يقول ابن عباس رضــي الله

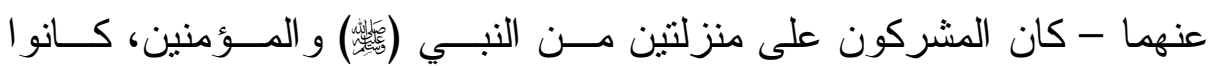

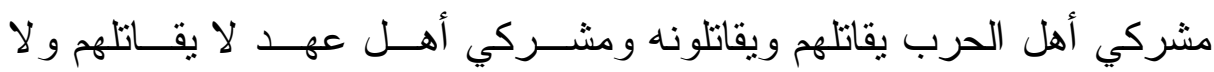
يقاتلونه.

- ولقد ثار الخلاف بين الفقهاء بشأن تمتع الذمبين بجنسية دار الإسلام

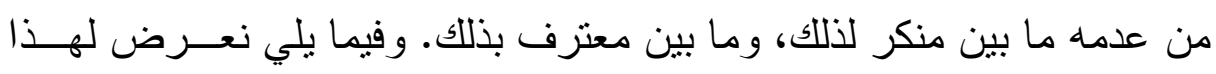

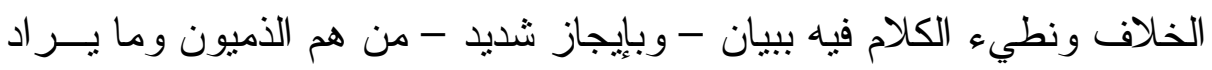
بكه? وذللك على النحو التالي:

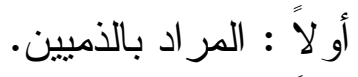

ثانياً: الخلاف المثار في تمتع الذميين بالجنسية الإسلامية.

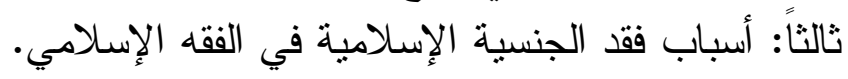

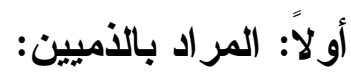
وهنا ينبغي إيضاح بعض المفاهيم وذلك على النحو التالي:

$$
\text { (أ) - مفهوم الأمة: }
$$

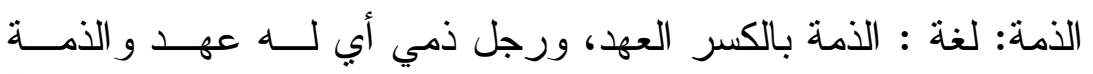

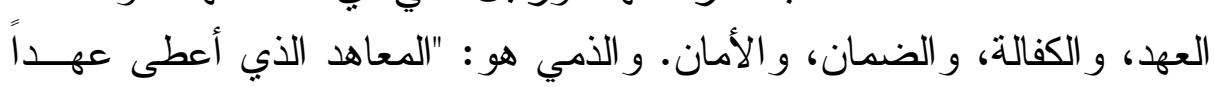

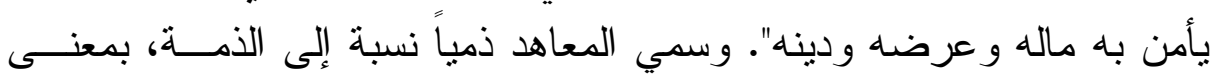
العهد، وقولهم في ذمني كذا أي في ضماني و الجمع ذمم وجاء في في التعريفــات:

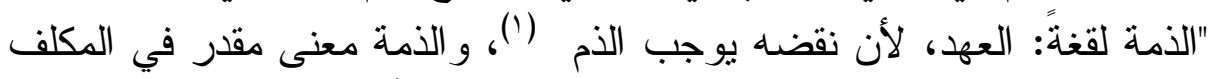

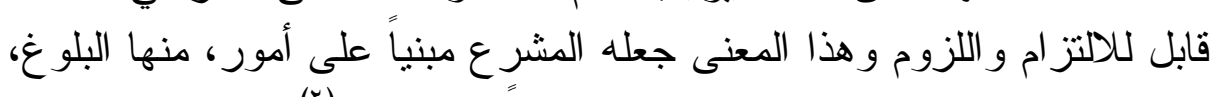

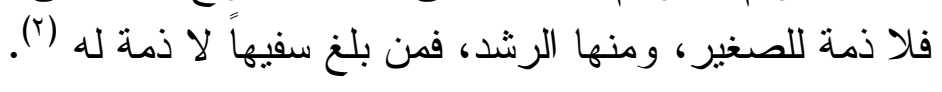

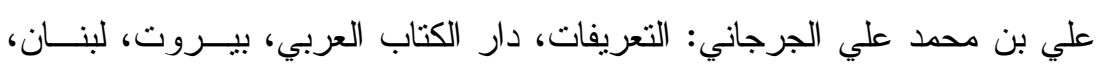

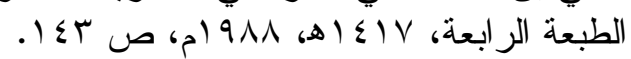

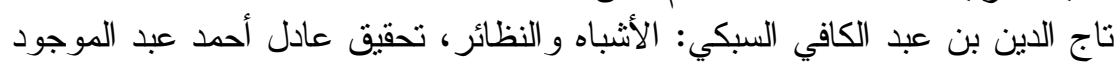

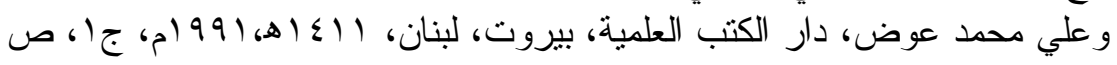

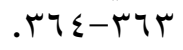




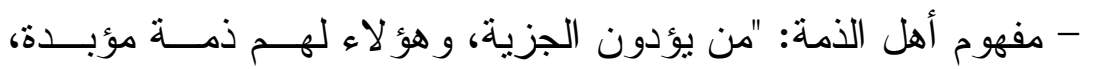

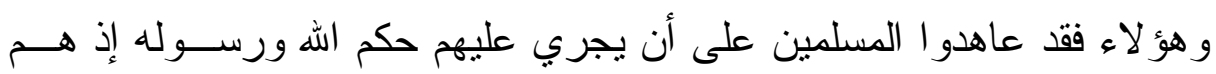

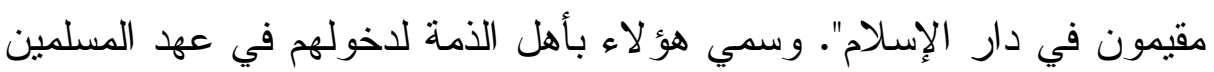

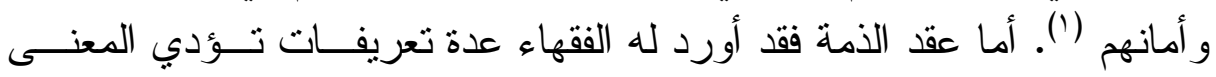
و الغرض ذاته ومن هذه التعريفات:

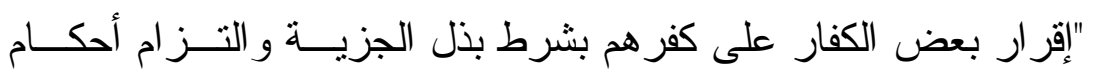

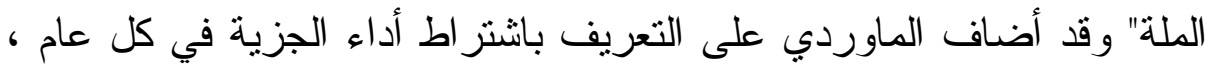

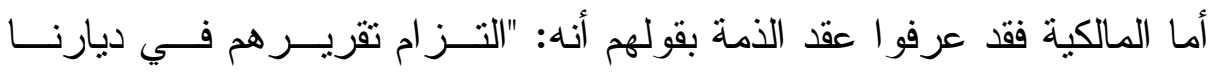
وحمايتهم و الذب عنهم و الاستسلام من جهتهم" وهو قول للثافعية.

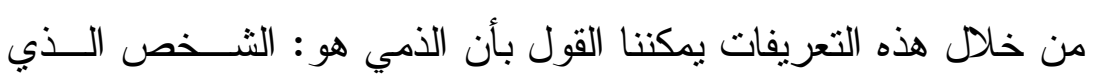

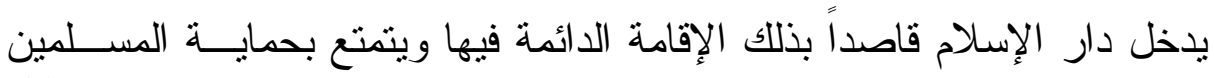

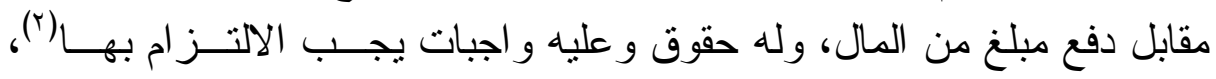

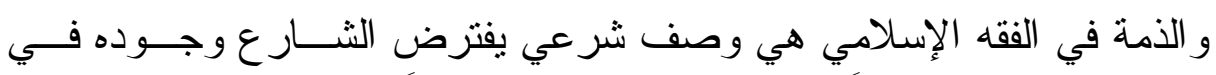

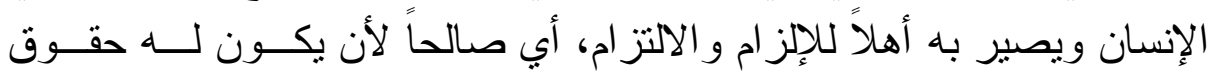
و عليه و اجبات (r).

- و عليه فالذميون هم غير المسلمين المقيمين في دار الإسـام بصــفة

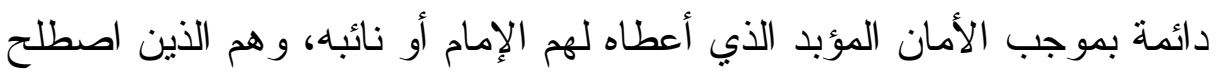
على تسميتهم بأهل الكتاب وهم في الأصل قسمان:

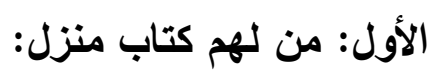

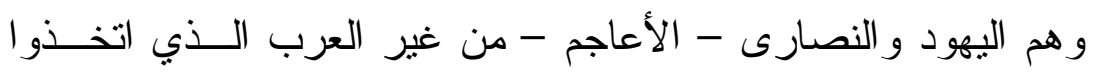

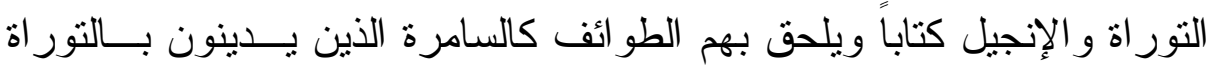

محمد عبد الرحمن بن عبد الرحيم المباركفوري أبو العلا: تحفة الأحسـوذي بشـــرح

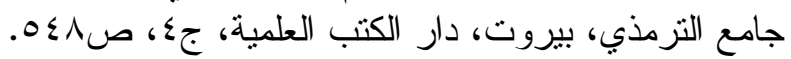

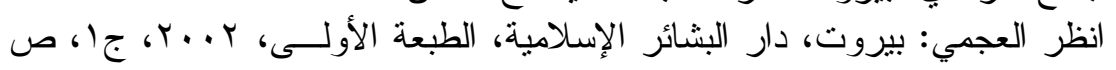
0

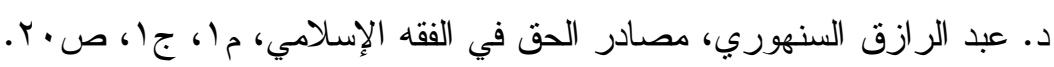

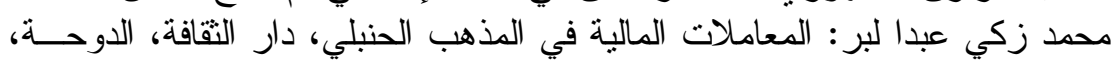

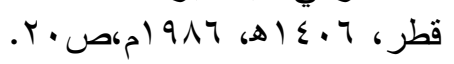


ويعملون بشريعة موسى عليه السلام ويدخل في النصارى جميع فرقهم ومسـن

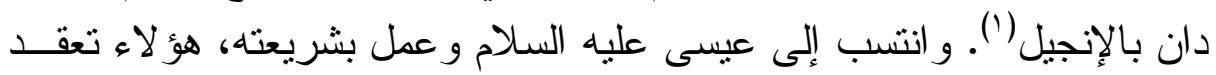

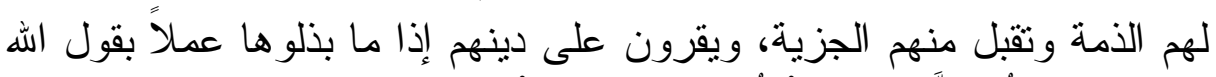

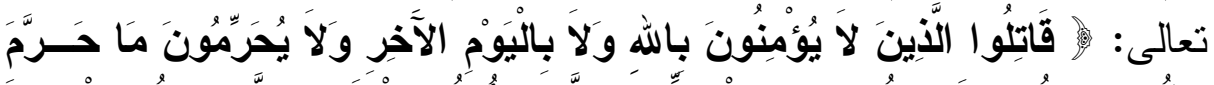

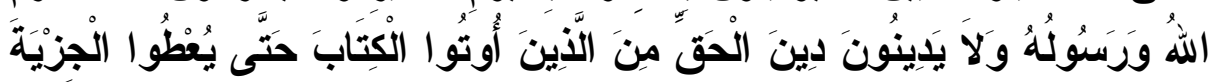

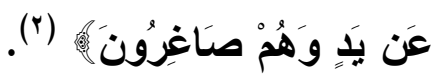

\section{الثاني: من لهم شبهة كتاب:}

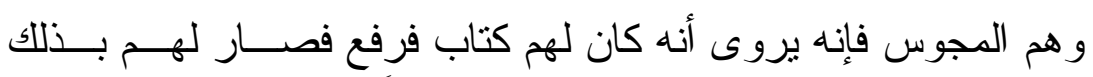

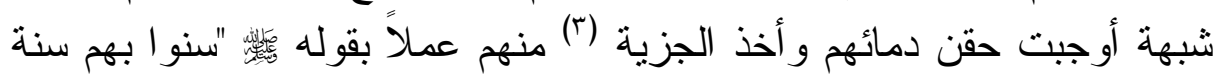

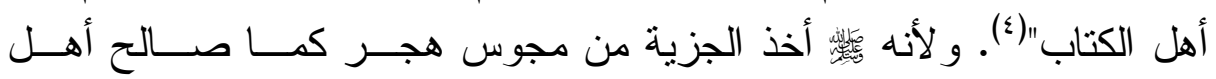

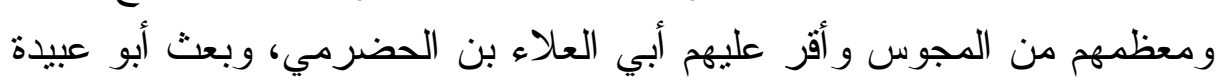

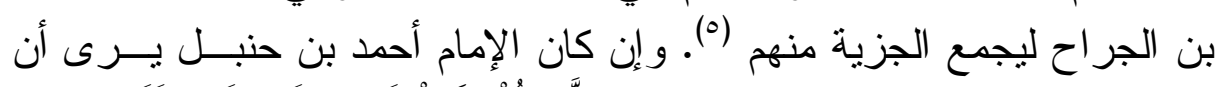

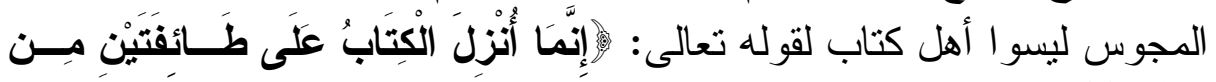

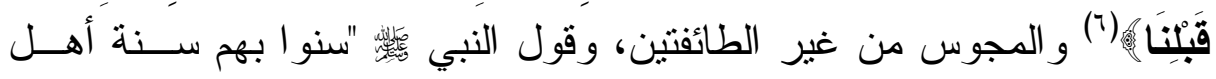

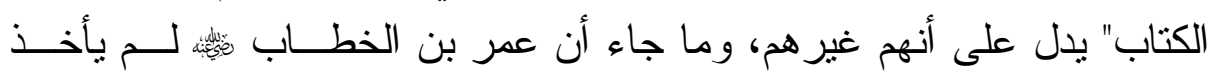

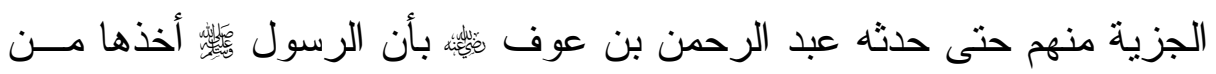

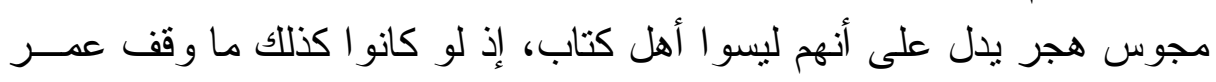

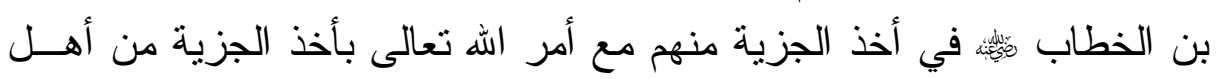
الكتاب، وما ذكروه هو الذي صلار لهم شبهة كتاب.

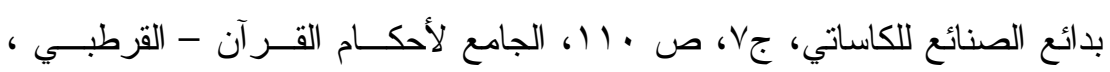

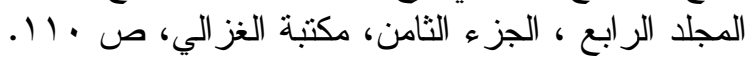

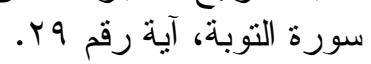

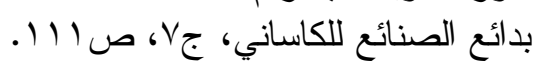

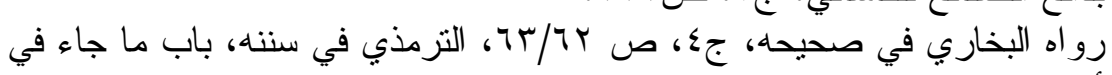
أخذ الجزية من المجوس.

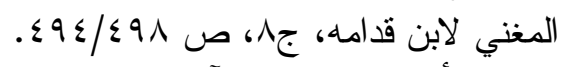

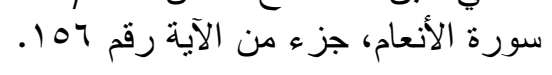

= إطلالة على الجنسية في الفقه الإسلامي والقانون الدولي الخاص 
العلد الثاني- الجزء الأول- السنة التاسعة والخمسون-يوليو Vا.r

\section{(ب) مشروعية عقد الأمة:}

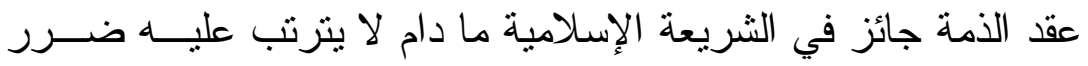

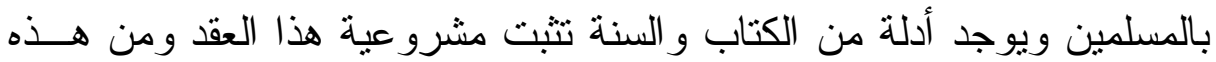

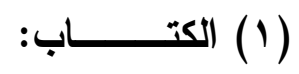

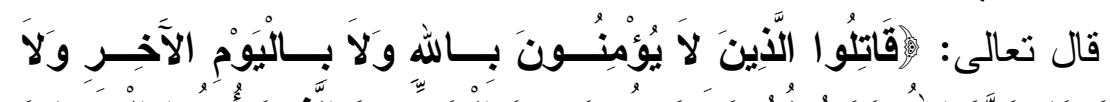

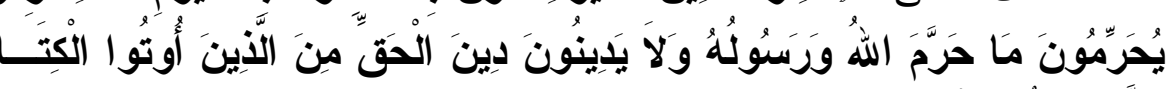

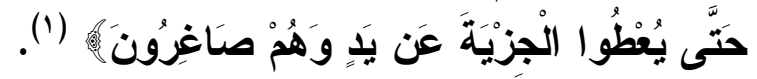

وجه الدلالة: الآية تدل على أن غير المســلمين إذا دفعــوا الجزيــة

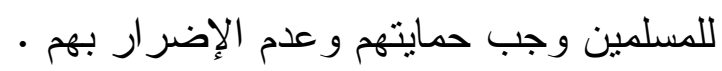

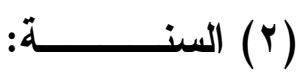

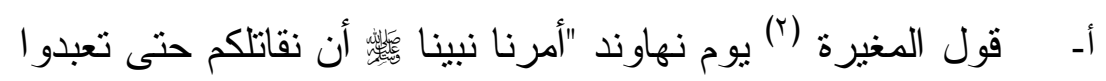

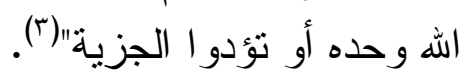

وجه الدلالة: قول المغيرة (أمرنا) يدل على الجواز إذ لو لـ يكن

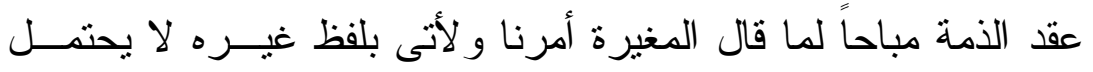
جواز هذا العقد.

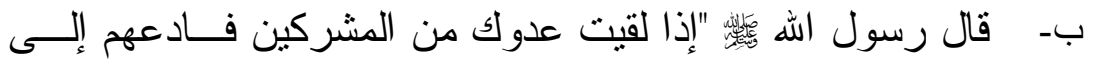

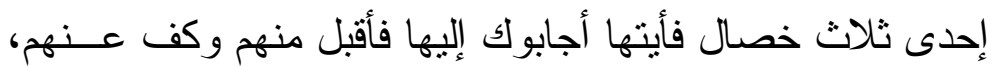

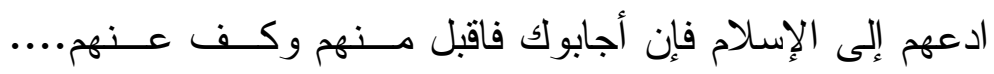

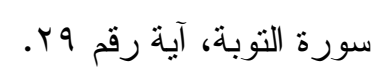

هو المغيرة بن شعبة بن مسعود بن بن معتب آنب النقفي صحابي مشهور أسلم قبل الحدييية

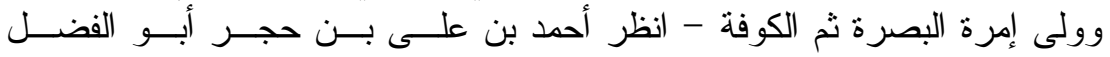

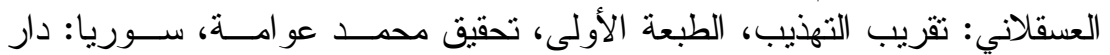

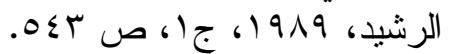

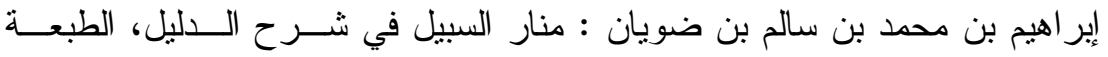

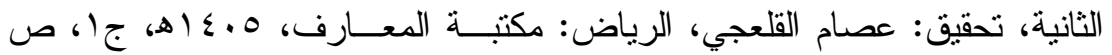




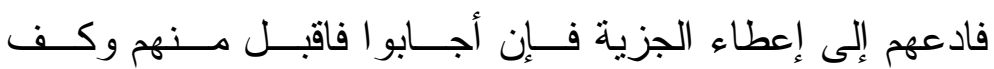
(1)"......

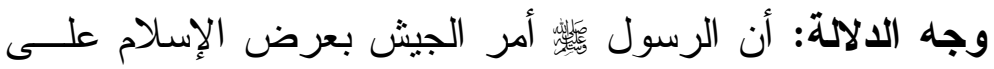

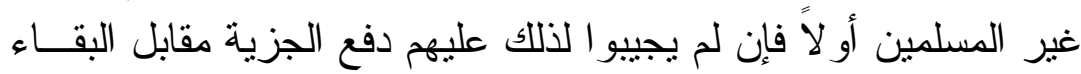
في دار الإسـلام، و هذا هو مفهوم عقد الذمة.

صفة عقد الذمة: مقائ

لا يصح عقد الذمة إلا بصدوره من الإمام أو من ينوب عنــهـ (r) و إذا

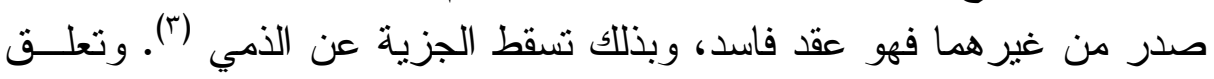
عقد الذمة بالإمام لأن هذا العقد من الأمور الكلية (ء). إضافة إلى أن الإمام هو

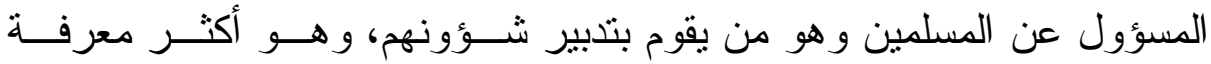

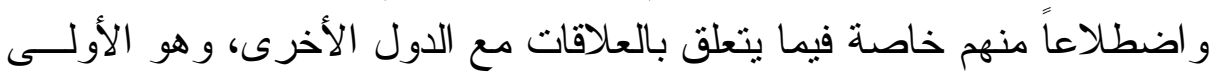
من غيره في إبر ام منثل هذه العقود.

\section{حكمة مشروعية عقد الأمة:}

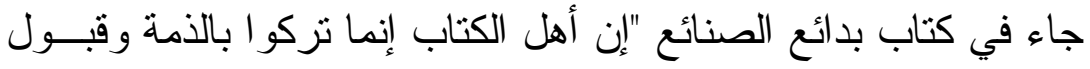
الجزية لا لر غبة فيما بؤخذ منهم أو طمع في ذللك، بل للاعوة إلـى الإســلام ليخالطو ا المسلمين فيتأملو افي محاسن الإسلام وشر ائعه وينظرو ا فيها فيروها

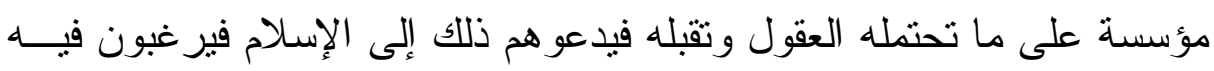
فكان عقد الذمة لرجاء الإسلام"(0).

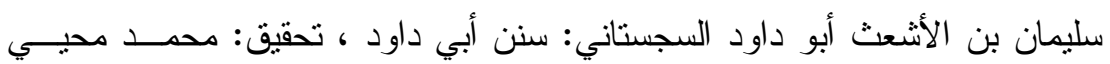

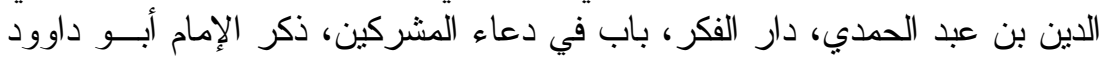

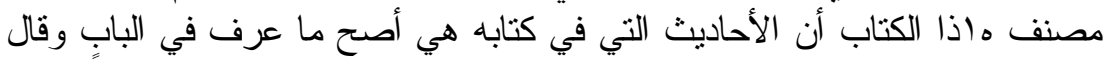

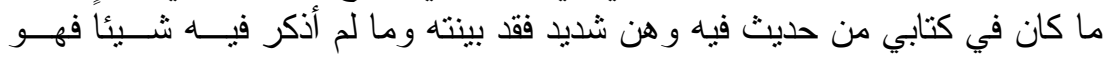

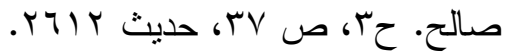

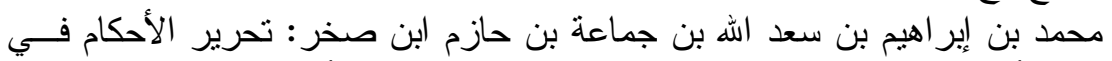

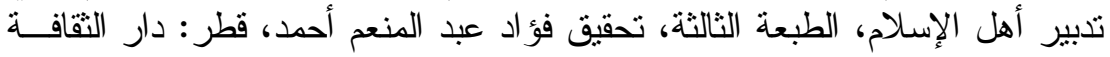

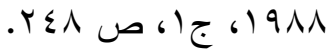

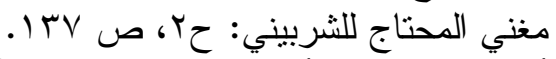

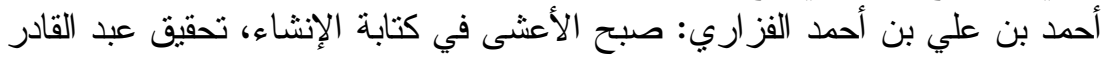

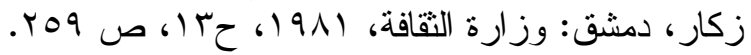

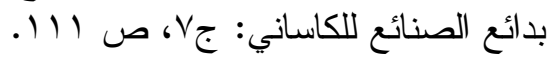

= إطلالة على الجنسية في الفقه الإسلامي والقانون الدولي الخاص 
فهذه إحدى غايات الإسـام وهي نشره في مختلف البلــدان باســـتخدام

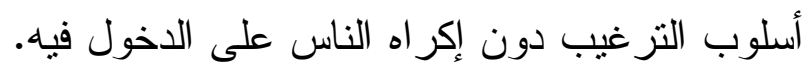

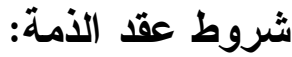

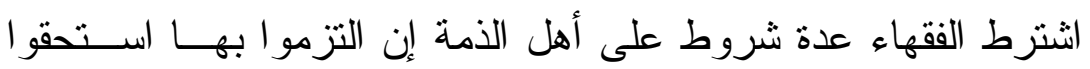

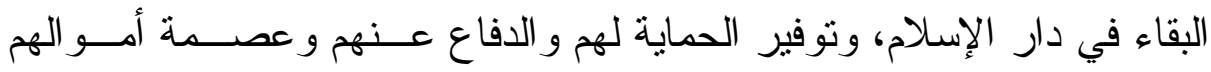

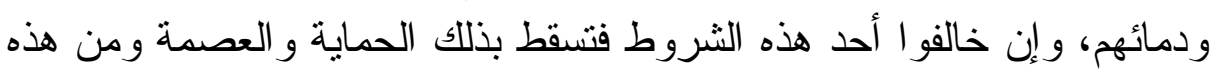
الشروط:

ا - علي أهل الذمة بذل الجزية للمسلمين في كل حول (').

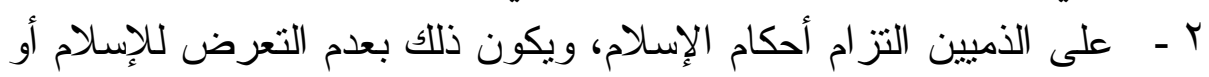

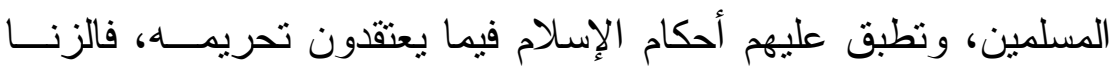

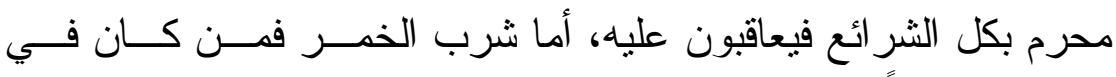

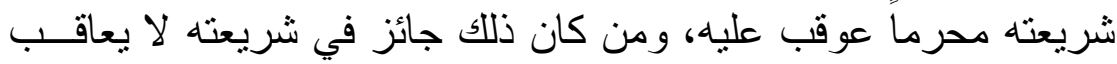
عليه لاعتقاد إباحته (؟).

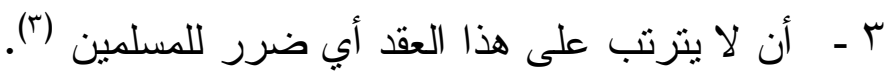
من يعقد له عقد الأمة: قال جمهور الفقهاء (£) يعقد عقد الذمة لأهل الكتاب ولمن لـــه شــبهة كتاب كالمجوس (ن) ثانياً: الخلاف المثار في تمتع الأميين بالجنسية الإسلامية (جنسية الأمي): الاتجاه الأول: الأميون لا يتمتعون بالجنسية الإسلامية:

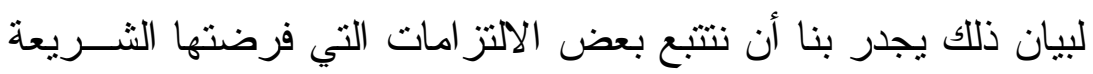

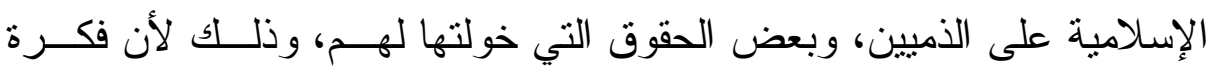

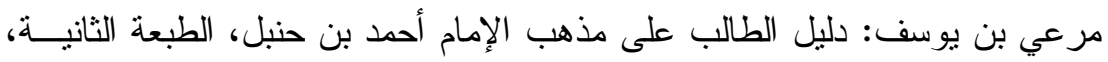

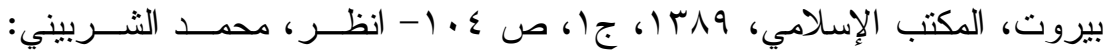

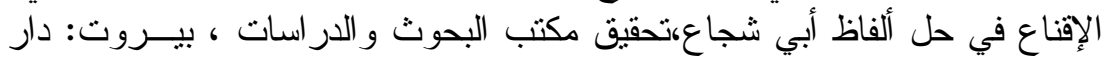

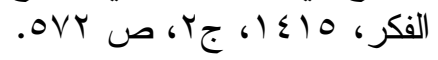

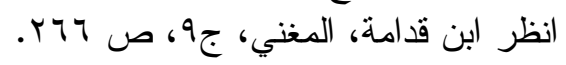

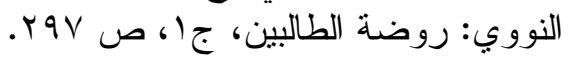

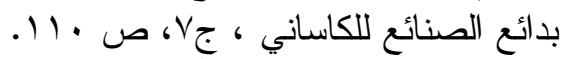

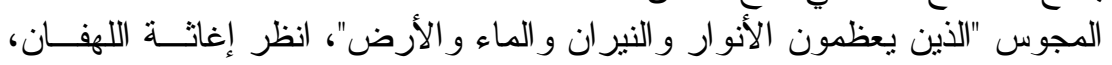

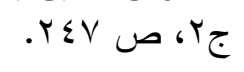


الجنسية في الفقه الإسلامي، رغم أنها معروفة معنى وموضو عاً إلا أنها ليست

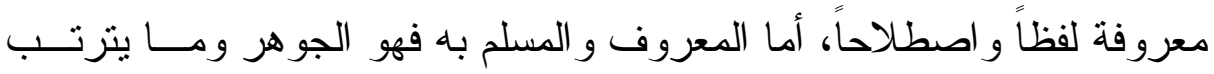
عليه من آثار . معند

- فإذا كانت الحقوق التي يتمتع بها المسلمون و الالتزامات المفروضة

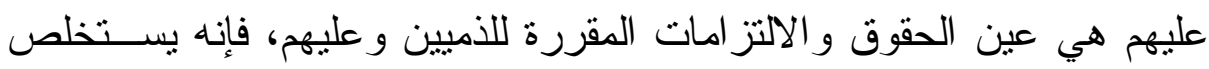

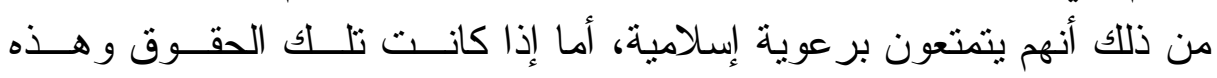

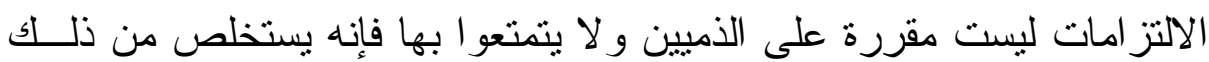

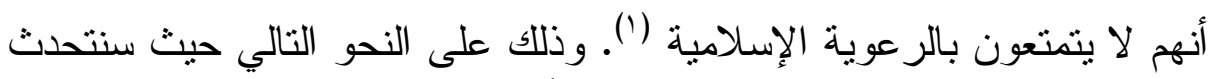

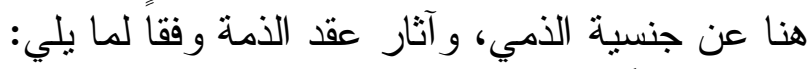

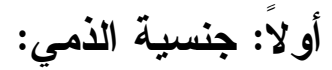

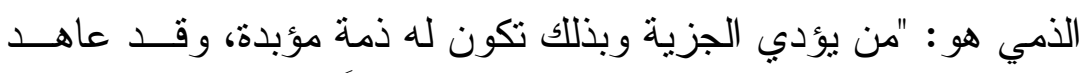

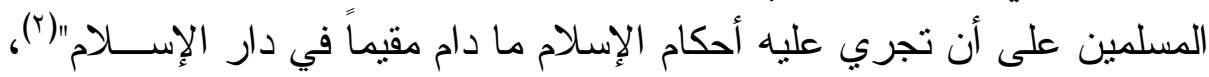

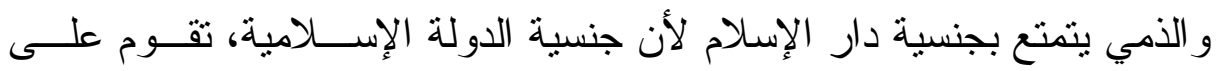

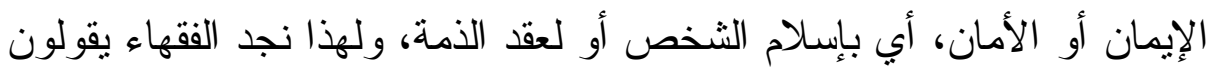

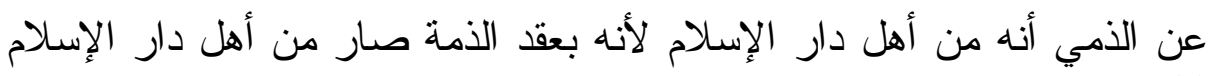

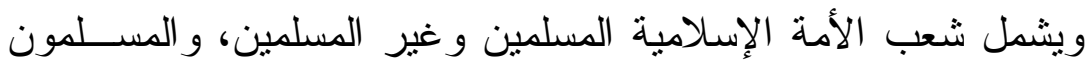

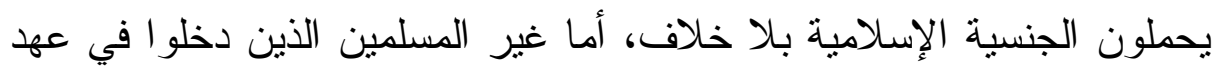

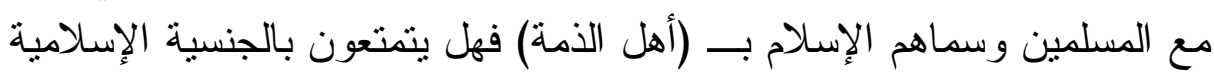
أم لا؟

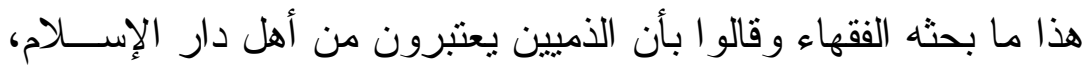

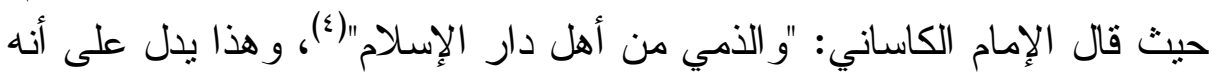

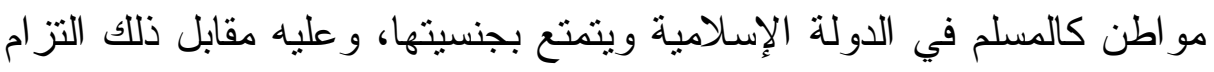

الأستاذ/ أحمد طه السنوسي: فكرة الجنسية في التشريع الإسلامي المقارن، مرجـع

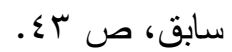

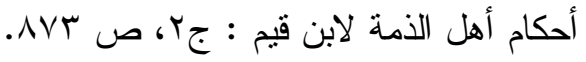

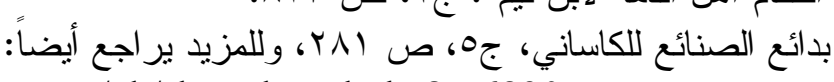
http://www.hurras.org/vb/showthread.php?t=6830

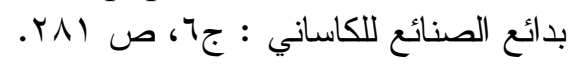

= إطلالة على الجنسية في الفقه الإسلامي والقانون الدولي الخاص 
أحكام الإسلام وو اجبات أخرى يحصل بها على حقوقه كالمسلم، وهذا من أهــ الآثار التي تترتب على الجنسية.

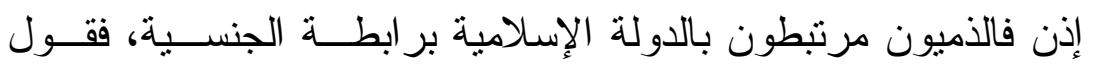

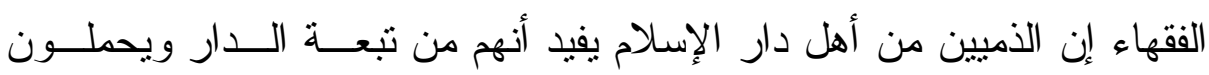

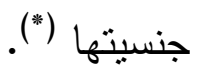

وقد اختلف الفقهاء في أساس الجنسية الإسلامية بالنسبة للـــمي علــى قولين:

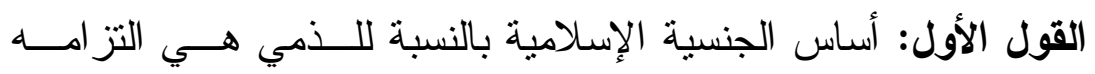

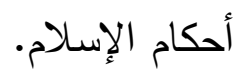

و هذا مخالف لما قاله الإمام الكاساني من أن سبب النز ام الذمي أحكــام

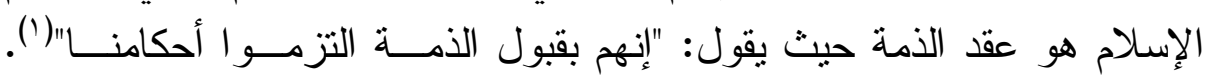
إضافة إلى أن المستأمن عند إقامته المؤقتة بدار الإسلام عليه الالتز ام بأحكامنا

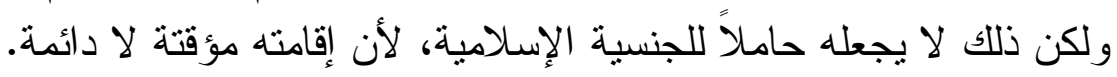

القول الثاني: أساس الجنسية الإسلامية بالنسبة للذمي هو عقد الذهـــة

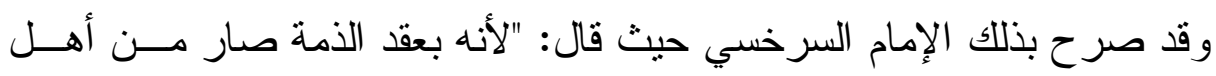

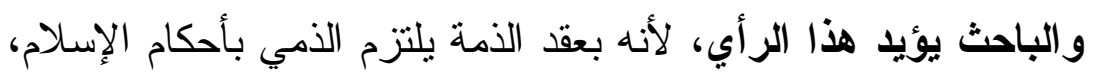

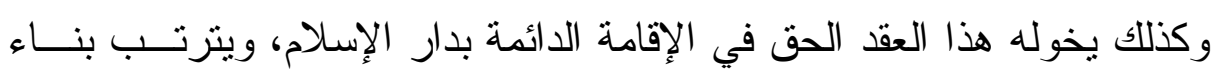

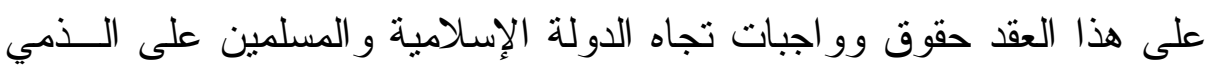

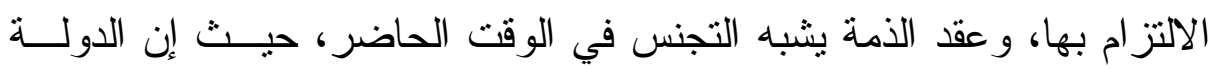

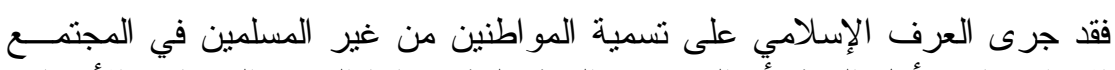

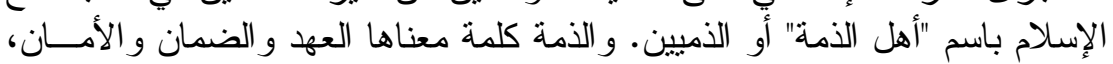

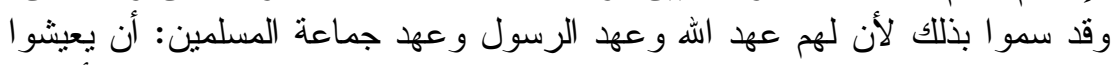

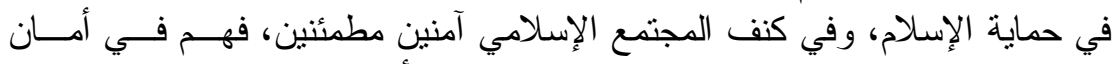

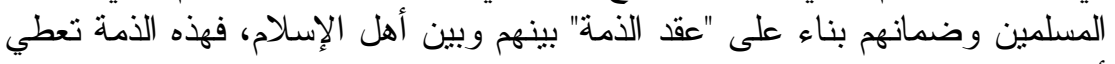

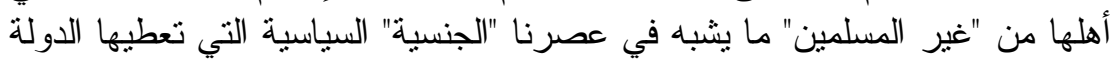

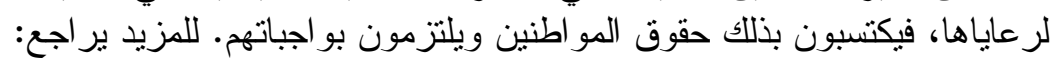
https://www.alimam.ws/ref/515.

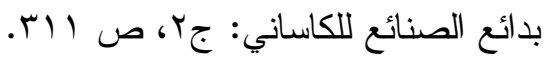

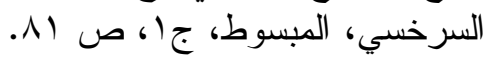

= إطلالة على الجنسية في الفقه الإسلامي والقانون الدولي الخاص 
الإسلامية هي وحدها التي تنتطيع منح الذمي جنسيتها، ولها الحق في الرفض بناء على الثروط التي تز اها مناسبة وكذلك الدول الحديثة تمنح جنسيتها مدــن فئن يطلبها إذا تو افرت فيه شروط معينة وو افقت الدولة على ذلك.

و عقد الذمة يشبه التجنس في الوقت الحاضر، لأن الفرد يكتسب جنسية

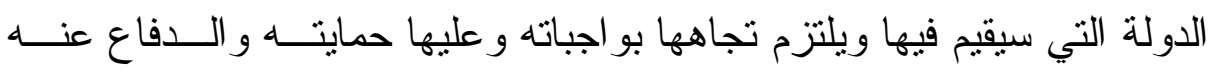

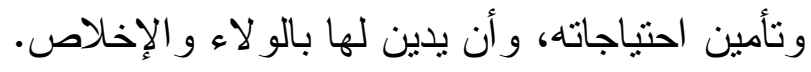

\section{ثانياً: آثار عقد الذمة:}

يترتب على عقد الذمة آثار بالنسبة للفرد و أفر اد أسرته، أمـــا بالنســبة

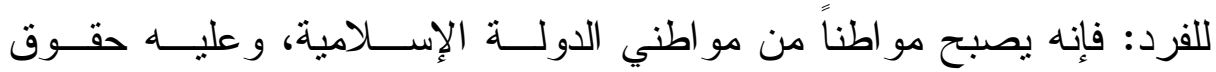

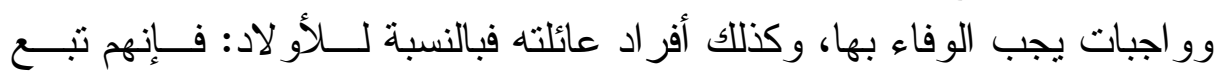

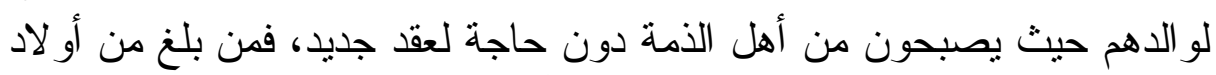

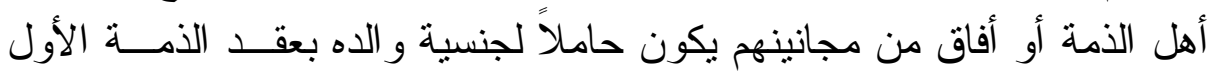

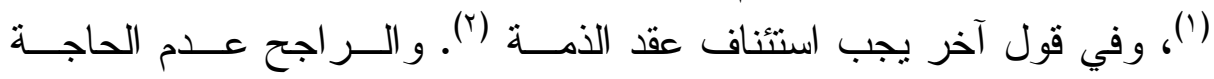
لاستئناف العقد لأن الولد تبع لو الده. فمن ولد في الدولة الإسلامية يأخذ جنسية

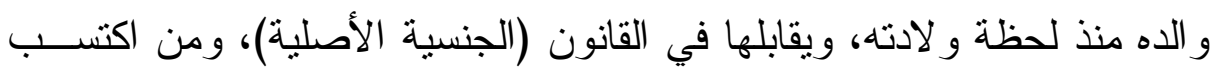

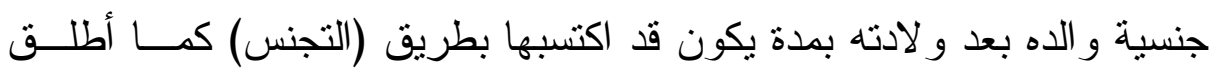

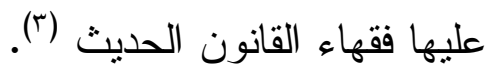

وكذللك في القانون الوضعي عندما يكتسب الفرد جنسية دولـــة جديـــدة

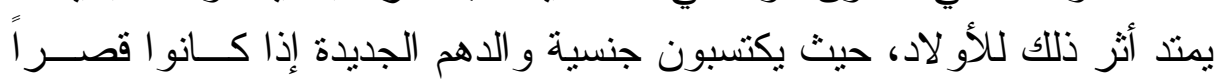

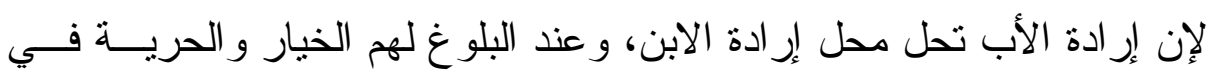

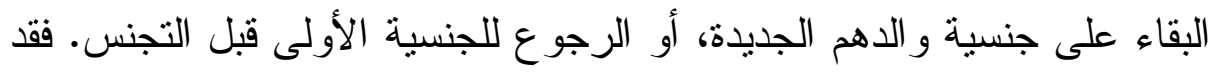

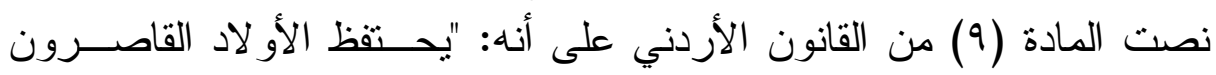

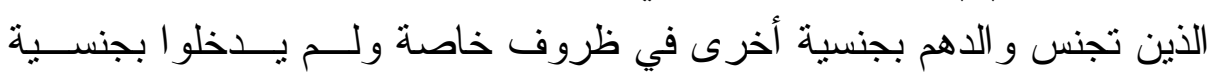

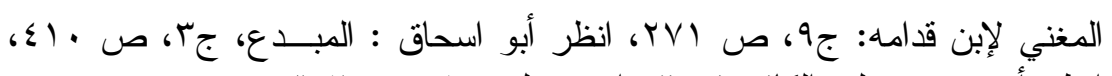

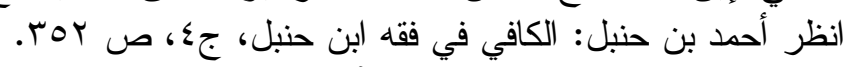

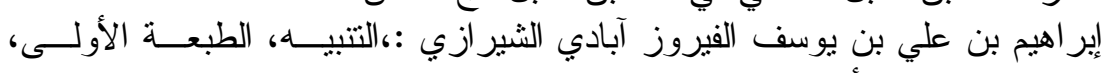

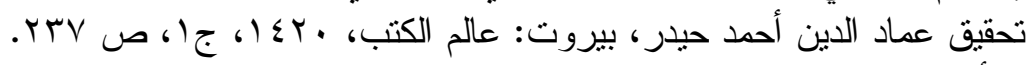

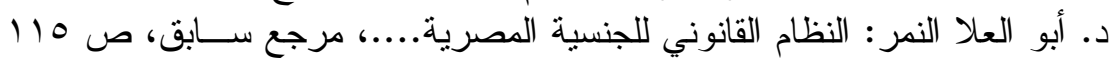
وما بعدها. 
و الدهم الجديدة بجنسيتهم الأردنية ببيان خطي خلال سنتين من بلـــوغهم ســن

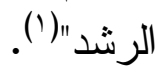

- و الزوجة كذلك فإنها تكتسب الجنسية الإسلامية بزو اجها من مســلم

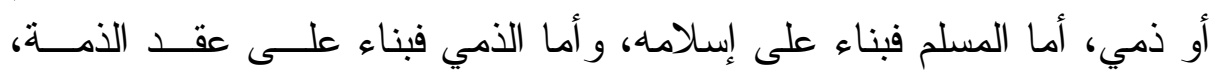

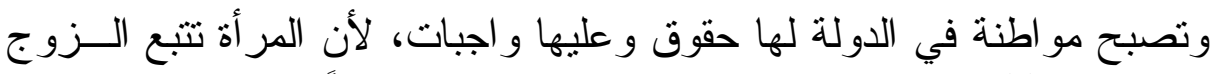

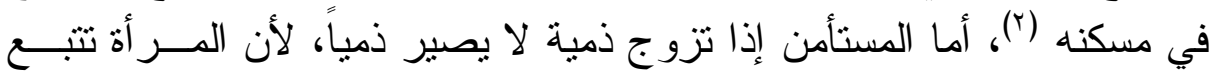

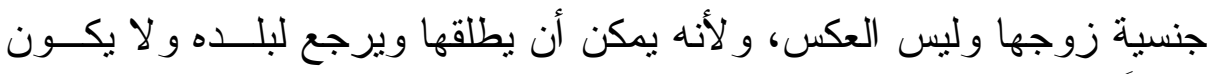
ملزماً بالمقام بدار ها.

و هذا ما نصت عليه القو انين الحديثة، بأن تتبع الزوجة جنسية زوجهــا

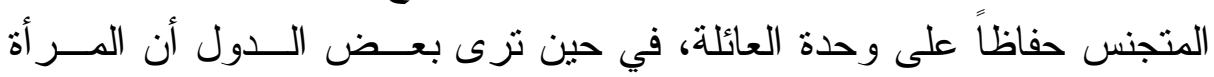

بالخيار في اتباع جنسية زوجها الجديدة أو البقاء على جنسيتها الأصلية (r).

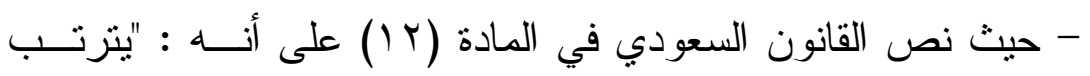

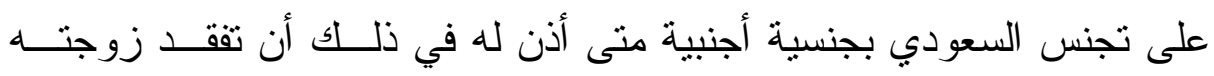

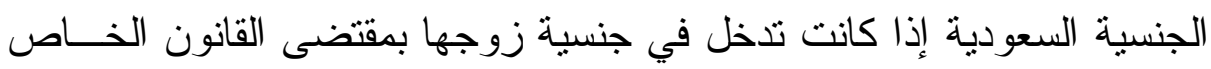

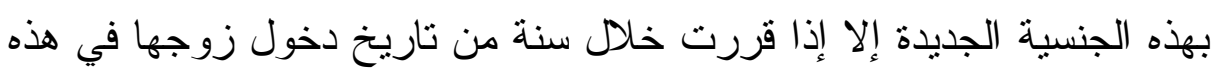

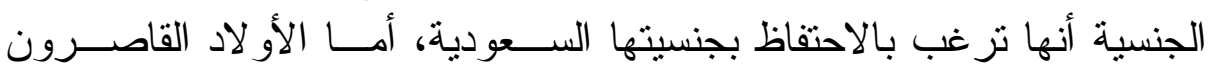

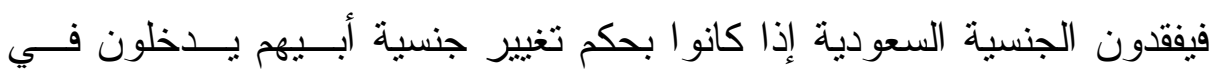

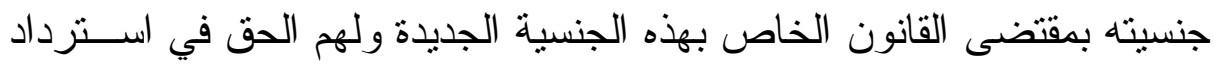

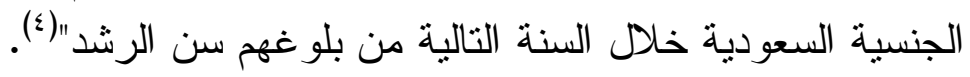

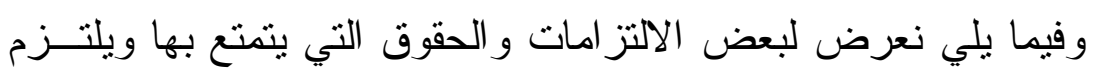

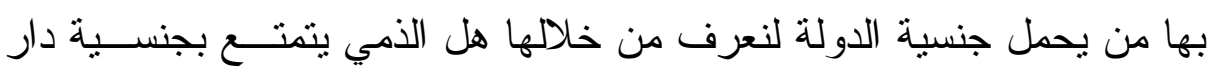

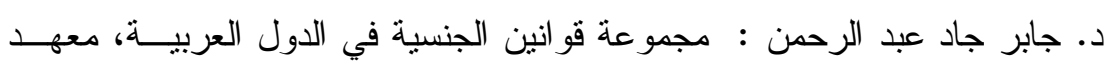

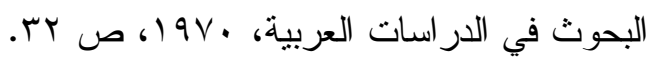

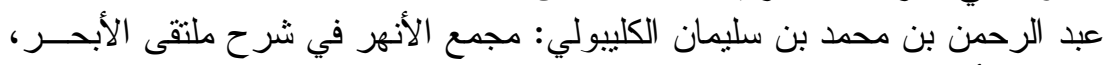

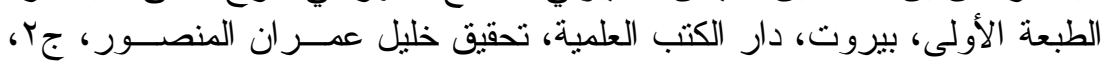
ص الطبعة الألى

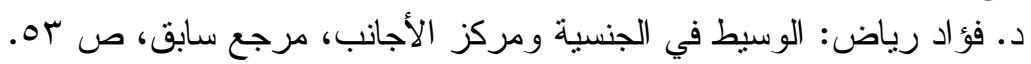

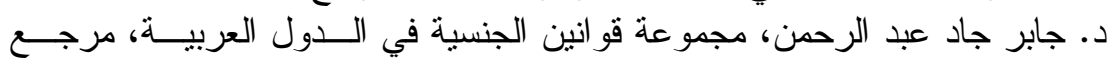
سابق، ص ع זा ا. 
الإسلام أم لا؟ وذلك حتى بتسنى لنا الوقوف على حقيقة مركزه القـانوني فــي تلك الدار

أ- التزام الخدمة العسكرية:

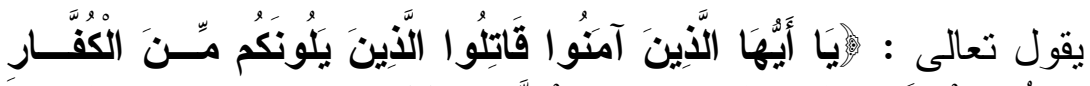

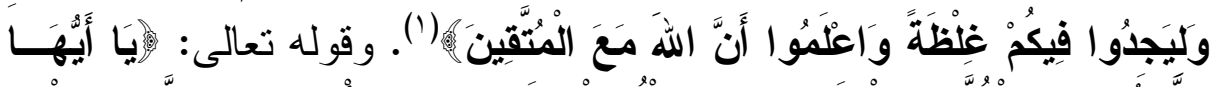

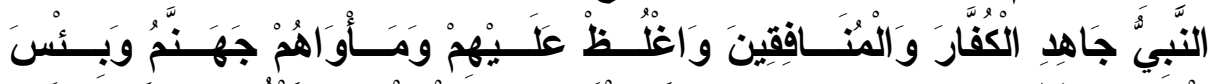

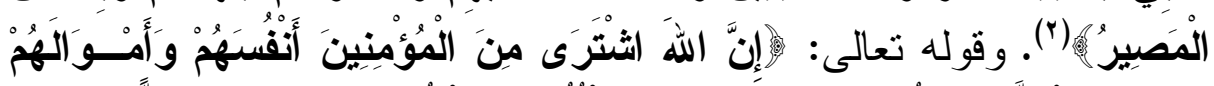

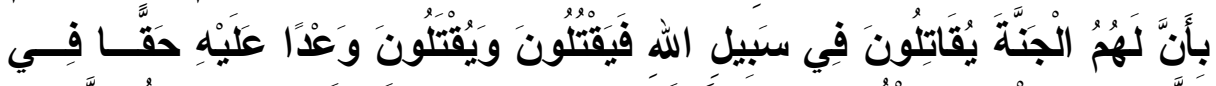

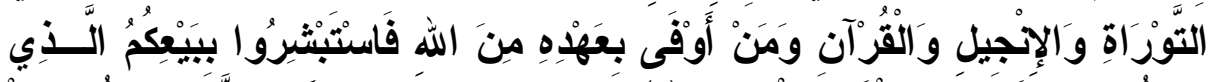

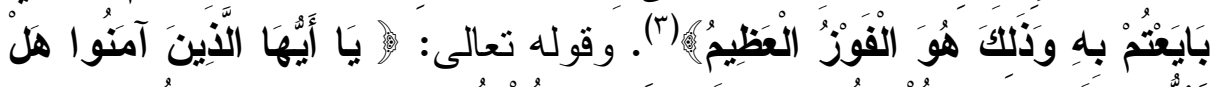

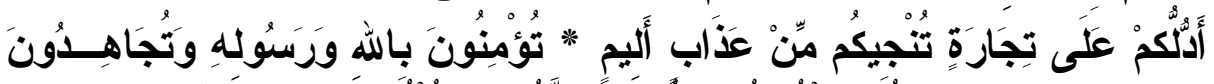

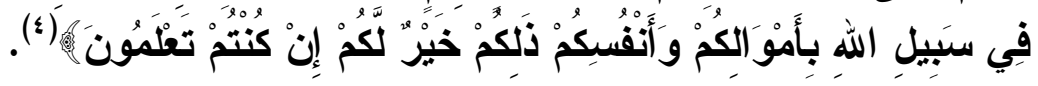

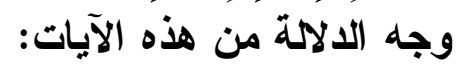

إن الله تعالى خاطب المؤمنين وحدهم و أمر هم بقتــــال الكفار ،و الغلظـــــة

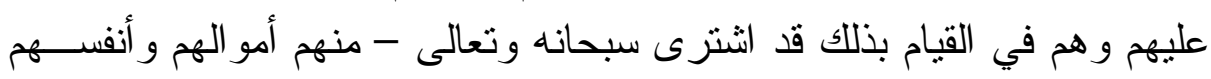

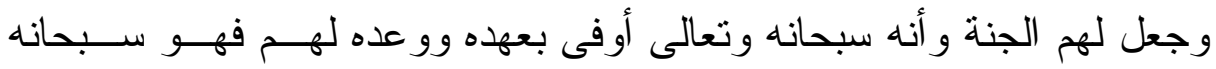

$$
\text { وتعالى لا يخلف المبعاد. }
$$

- و على ذلك فالمسلمون وحدهم هم الذين يلتزمون بالخدمة العســكرية

فلا جهاد على كافر ولا ذمي ويجب عليه بذل الجزية لنذب عنه لا ليذب عندا.

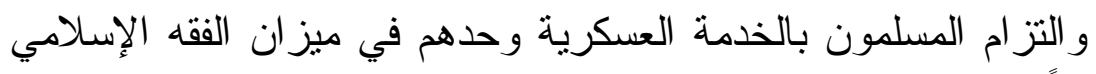

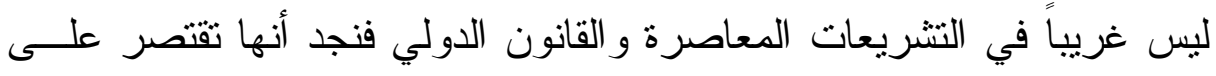
وطنييها دون الأجانب.

بيد أنه يلاحظ أن الذميين قد استعان بهم المسلمون في الحرب و القتال

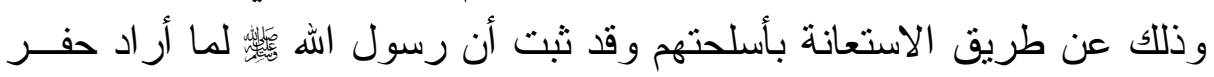

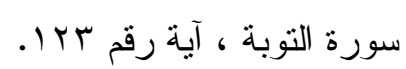

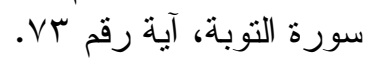

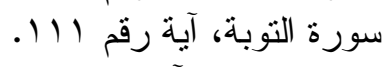

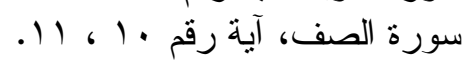

= إطلالة على الجنسية في الفقه الإسلامي والقانون الدولي الخاص 
الخندق استعار من يهودي آلات الحفر، ومع ذلك فإنه لا يعد من قبيل الالتز ام

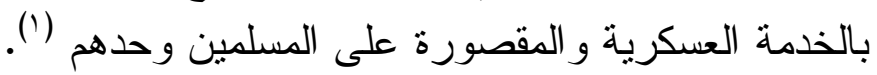
ب - التزام المسلمين بالزكاة والأميين بالجزية:

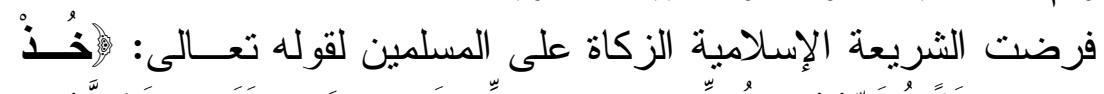

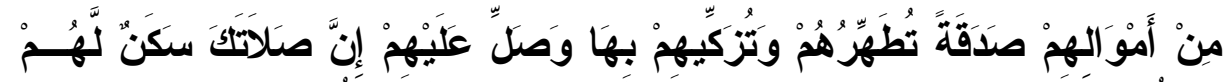

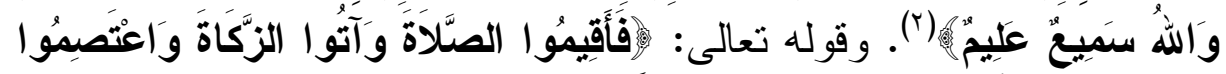

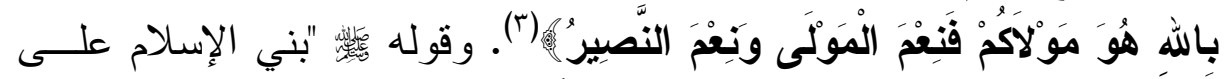

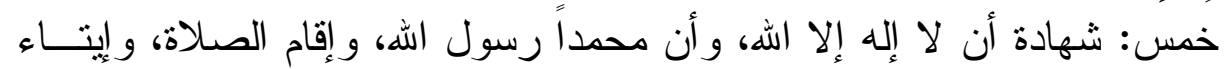

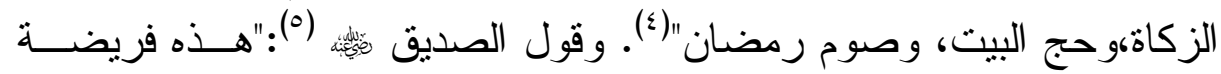

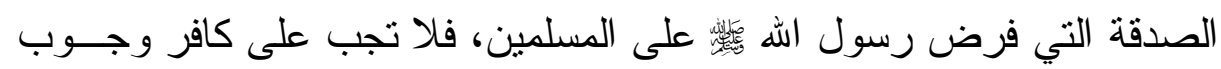
مطالبة و إن كان بعاقب على تركها في الآخرة".

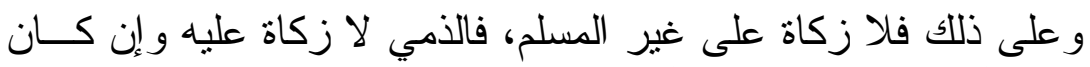

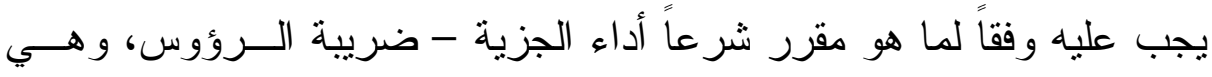

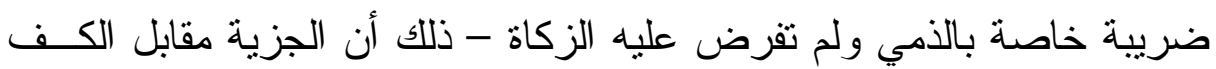
عنه وحمايته أو مقابل ما يتمتع به من حقوق في في دار الإنه الإسلام. ج - ممارسة الحقوق السياسية:

يقصد بالحقوق السياسية تلك الحقوق التي يكتسبها الثخص باعتبــاره

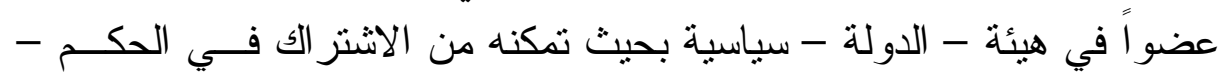

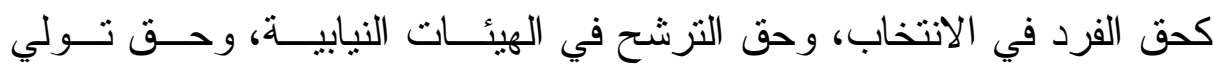

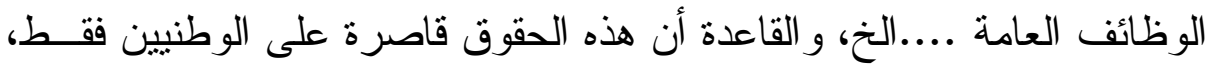

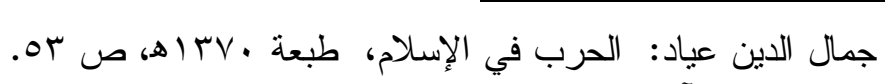

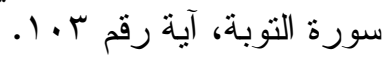

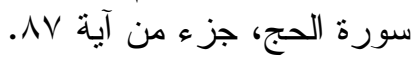

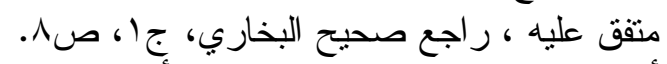

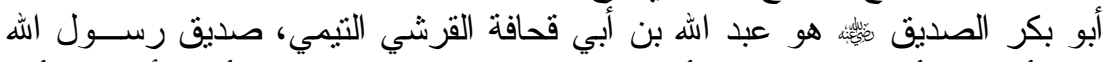

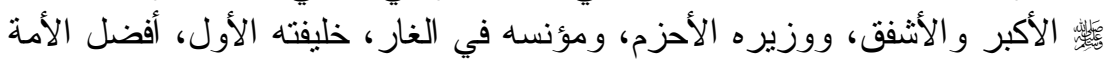

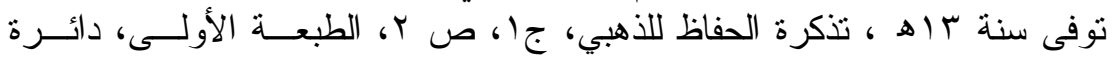

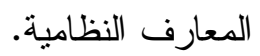


ذلك لأن الوطنيين ما هم إلا عنصر من العناصر المكونة للدولة وهـي التـي لـي

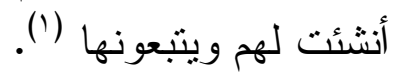

- و الأجانب ليسو ا جزءاً من الدولة و اثشتر اكهم في الحقوق السياســية

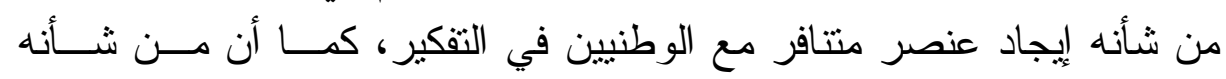
التعارض مع إلتز اماتهم تجاه دولهم التي يحملون جنسيتها.

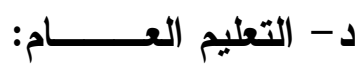

إن الثريعة الإسـامية قررت إلز امية التعليم، وقصرت هذه الإلز اميــة

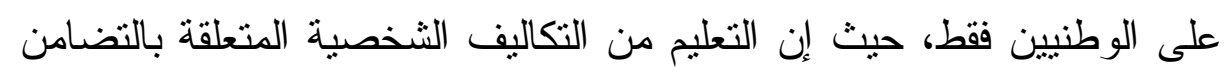

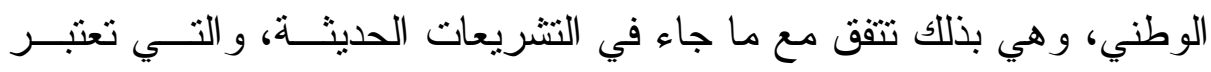

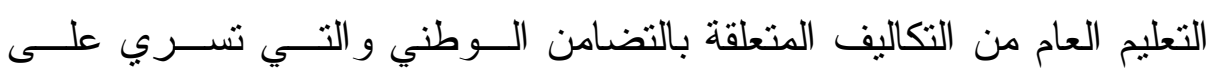

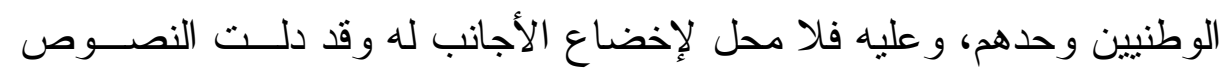

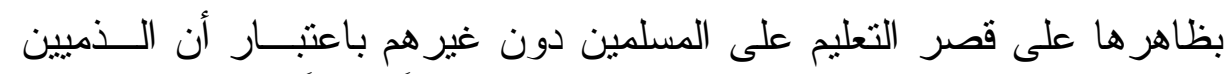

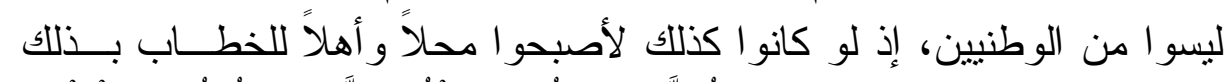

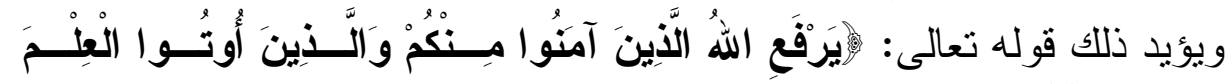

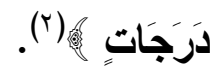

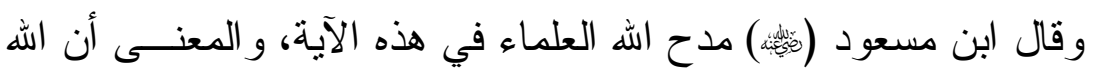

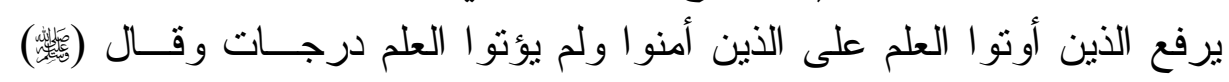
"طلب العلم فريضة على كل مسلم". هـ - ولاية القضاء و الثهادة:

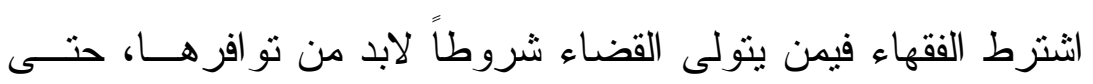

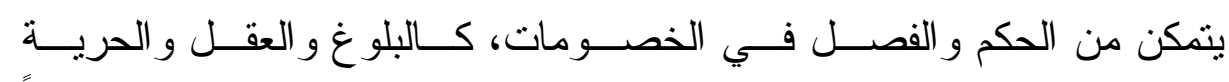

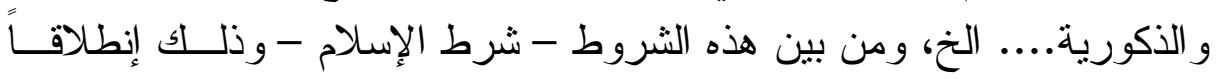

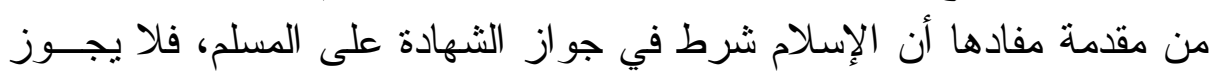
لغير المسلم أن يشهد على المسلم فيقاس القضاء على الألى الثهادة.

د. علي صادق أبو هيف: القانون الدولي العام، مرجع سابق، ص 99.

$$
\text { سورة المجادلة، جزء من الآية رقم } 11 .
$$




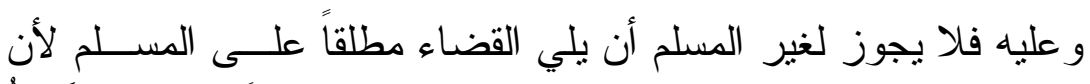

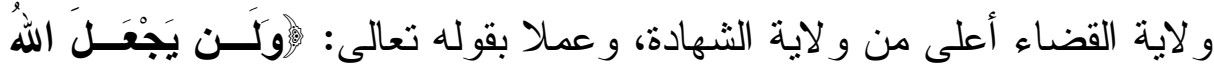

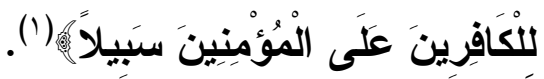

الاتجاه الثاني: الأميون يتمتعون بالجنسية الإسلامية:

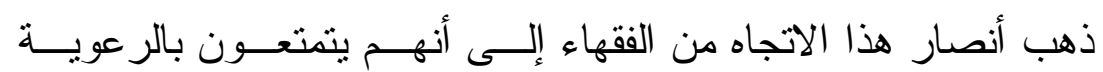

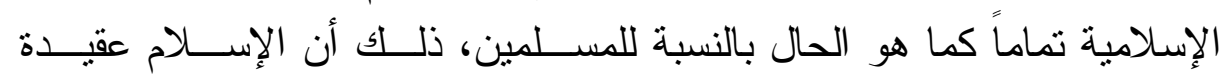

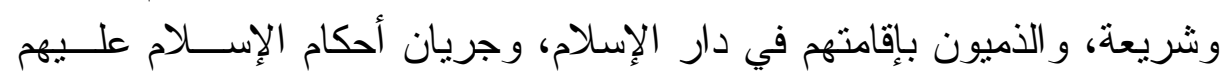

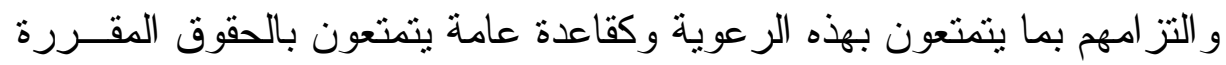

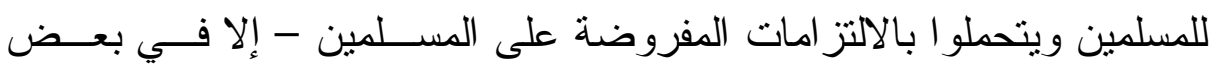

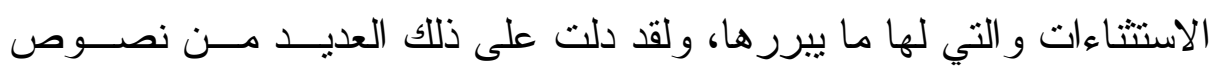
الفقهاء.

فقد جاء في بدائع الصنائع للكاساني ولو اثـــترى المســتأمن أرضـــاً

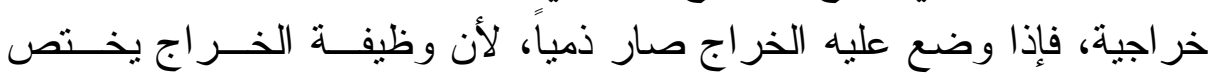

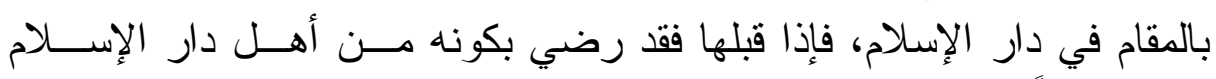

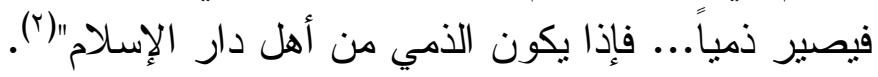

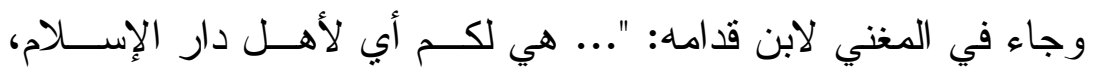

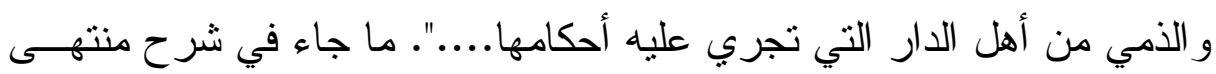

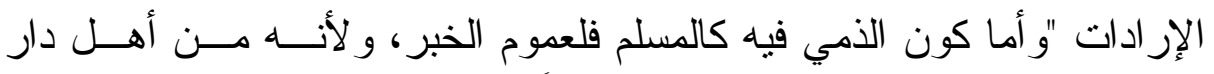

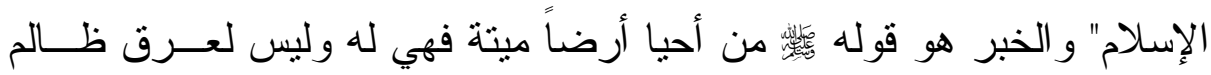

حق (ॅ)

- وجاء في فتح القدير "... و لأنه بعقد الذمة صـار من أهل الــــار ..."

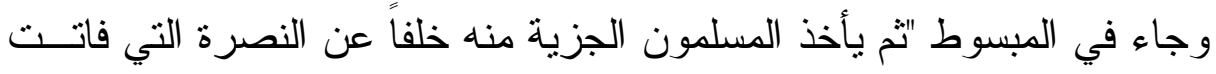

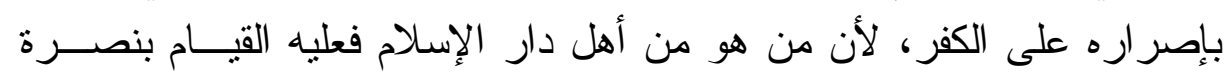
الدار ".

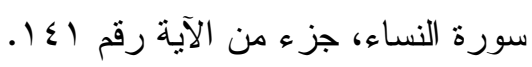

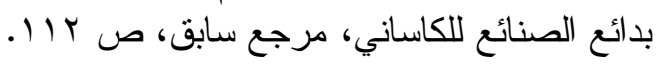

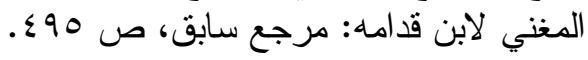


- وما جاء في حاثية ابن عابدين "... أو صـار لها - أي المسـتأمنة

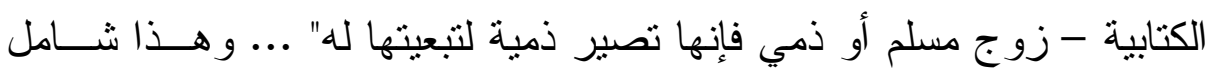

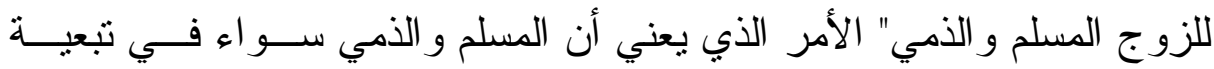

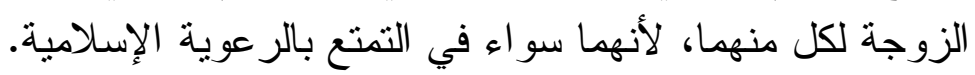
- ما قاله الثيخ أبو زهرة - عند حديثه عن الثروط اللازمة لتصـير الثير

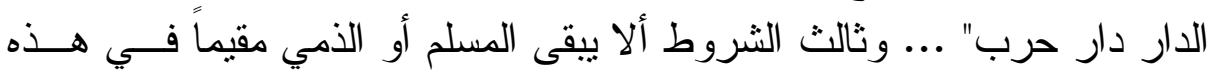
الدار - فالذمي يحمل رعوية دار الإسلام (')

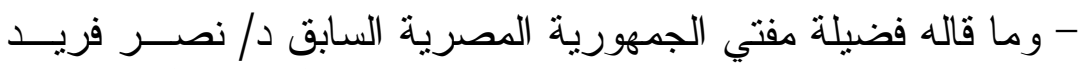

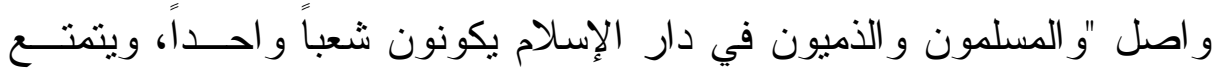

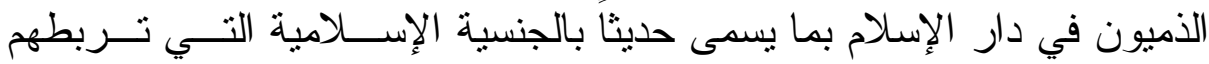
بالدولة الإسلامية... فالإسلام من حيث كونه عقيدة يعتبر المسلمين جميعاً أخوة

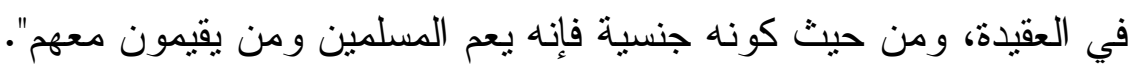

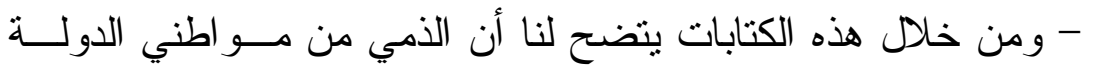

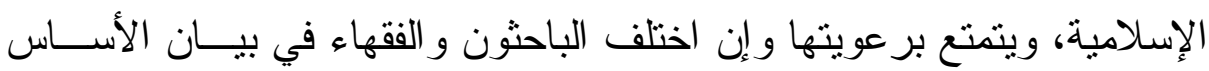

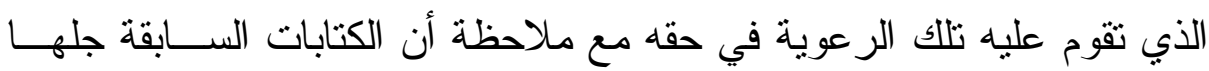

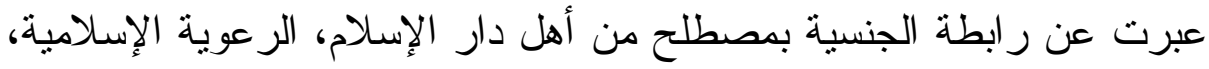

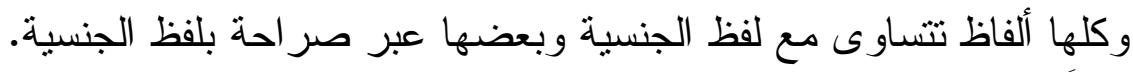
ثالثاً: أسباب فقد الجنسية في الفقه الإسلامي: أهل الذمة يقيمون في دار الإسلام إقامة دائمة مقابــلـل التــز ام أحكــــام

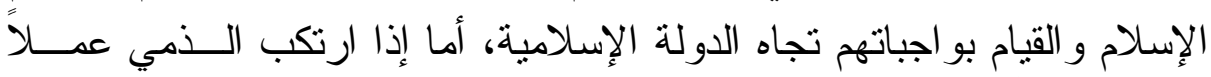

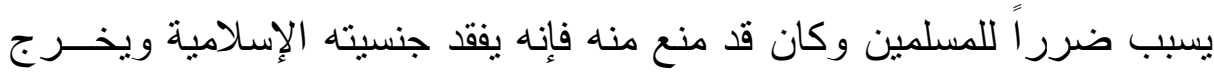

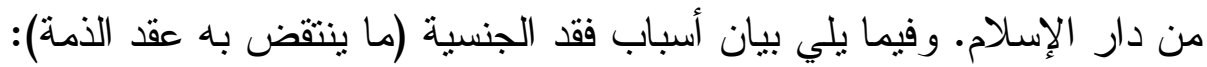
قال الحنفية ينتقض عقد الذمة بارتكاب الذمي أمرين:

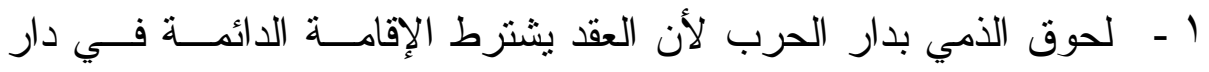

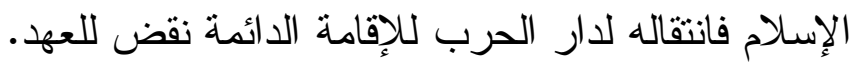

الثيخ/ محمد أبو زهرة: العلاقات الدولية في الإسلام، القاهرة، دار الفكر العربـي،

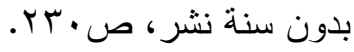


r - غلبة الذمبين على موضع لمحاربة المسلمين لأنهم بذلك صــارو ا حربــاً

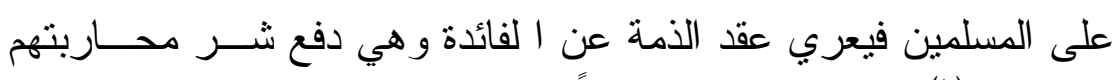

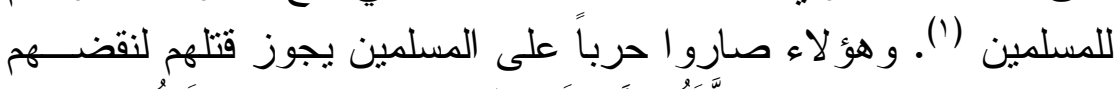

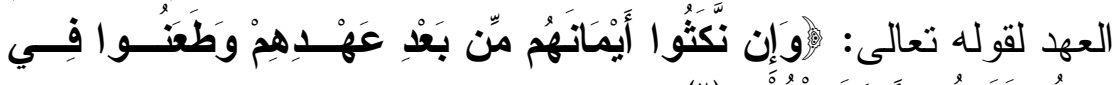

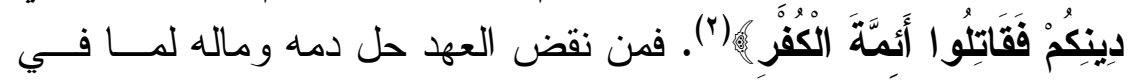

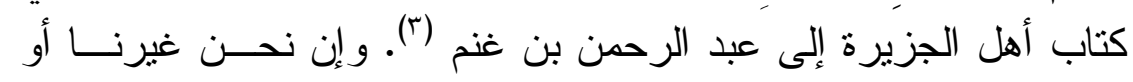

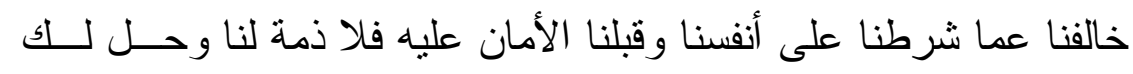

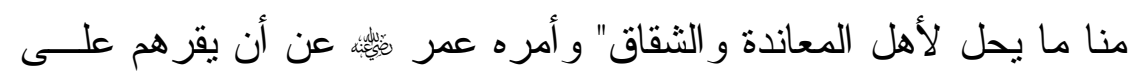
ذلك.

أما بقية الفقهاء فقد قالو ا بأن عقد الذمة ينتقض بأمور أخرى إضـافة لمــا قاله الحنفية و هي: 1 - - إذا امتتع الذمي من أداء الجزية للمسلمين. r - - إذا امتتع الذمي من التز ام أحكام الإسلام.

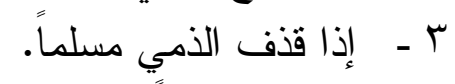
ع - ـ إذا قتل مسلماً أو فتنه عن دئها.

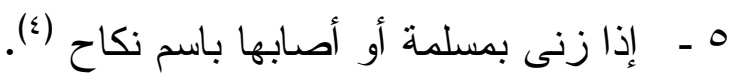

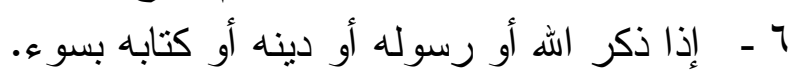

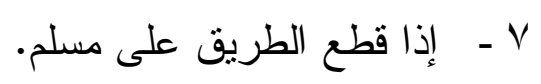
1 - إذا تجسس لصالح غير المسلمين أو آوى جاسوساً (0).

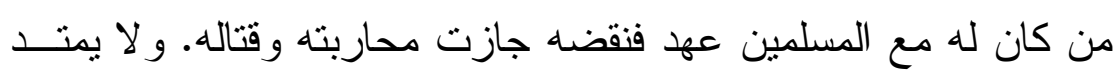

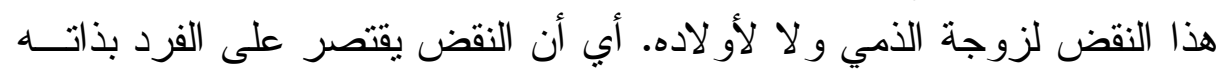

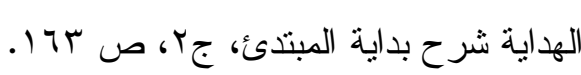

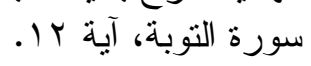

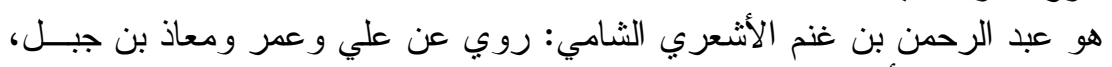

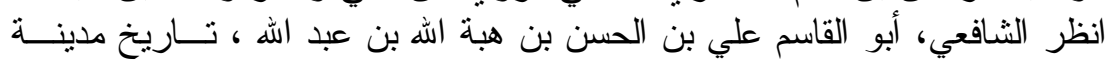

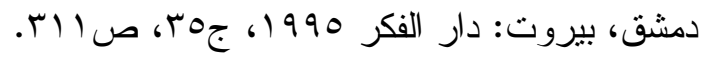

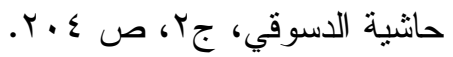

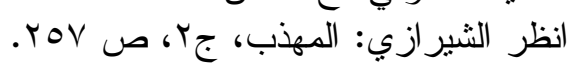

= إطلالة على الجنسية في الفقه الإسلامي والقانون الدولي الخاص 


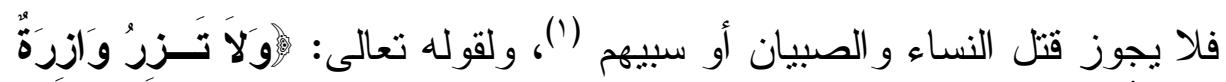

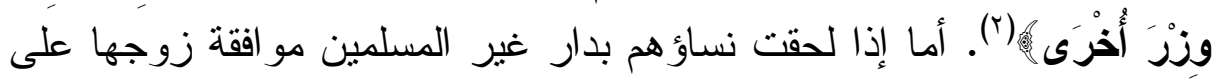

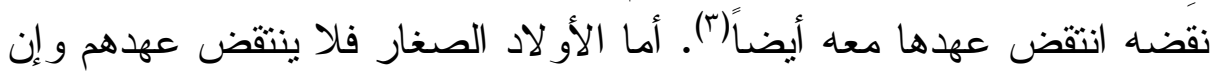
لحقو ابدار غير المسلمين.

\section{أسباب فقد المسلم للجنسية الإسلامية:}

تتنقض جنسية المسلم بعدة أمور منها:

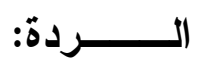

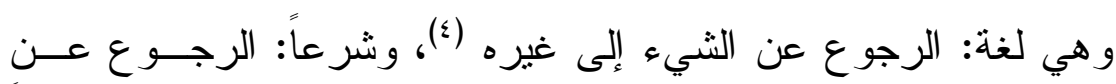

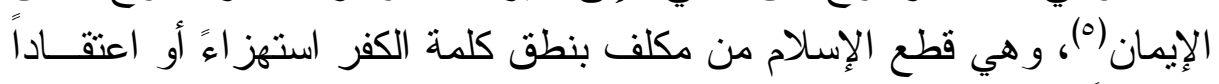
أو عناداً.

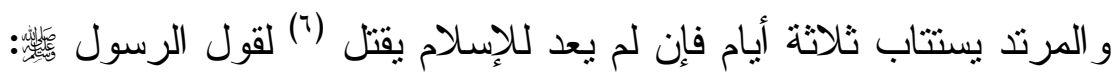

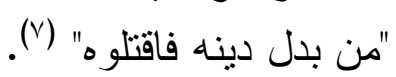

أما بالنسبة لزوجة المرتد: فمن ارتد زوجها عن الإسلام لا تقع الفرقــة بينهما إلا إذا انقضت العدة قبل أن يتوب، عندها تنين زوجته فئه منه و لا سبيل له له

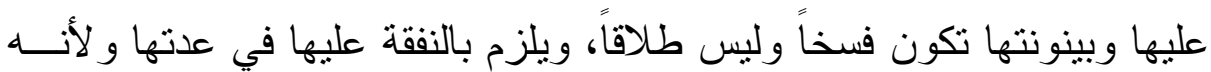

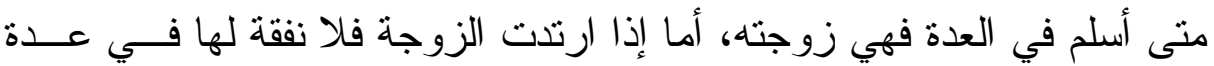
و لا غير ها.

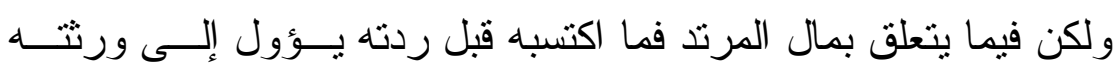

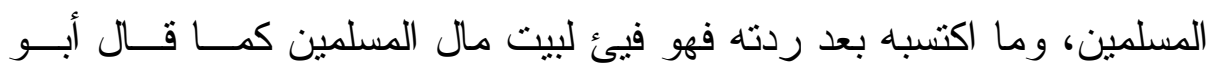

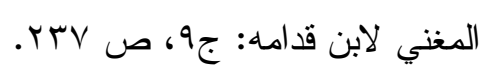

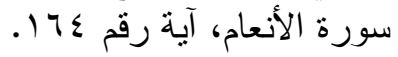

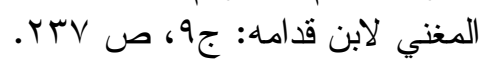

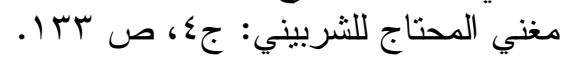

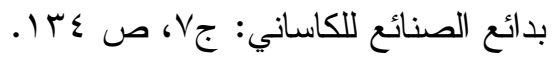

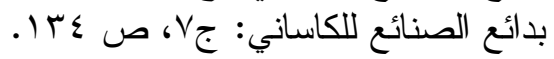

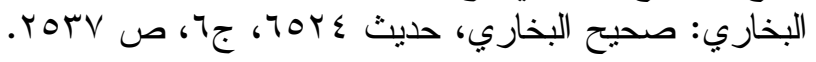


حنيفة، وللورثة عند الصحابين ('). وو افق المالكية، و الثـــافعية، و الحنابلـــة (؟) أبو حنيفة في قوله.

كما قالو ا بحرمة ذبيحته لأنه لا ملة له، و لأنه رخص بذبائح أهل الكتاب

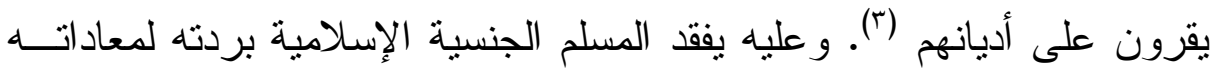

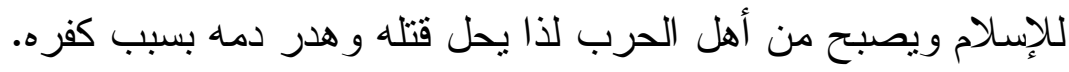
أسباب فقد الجنسية في القانون الوضعي:

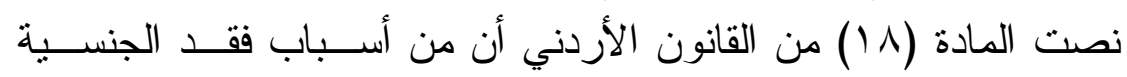

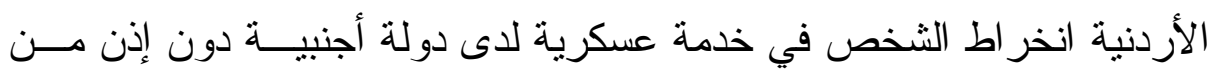

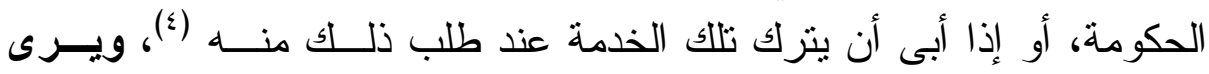

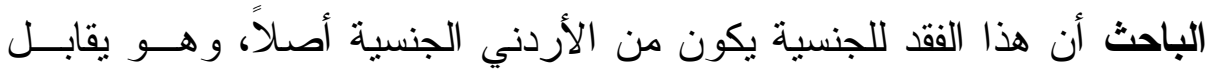
المسلم الذي يرتد عن إسلامه ويلتحق بديار غير المسلمين.

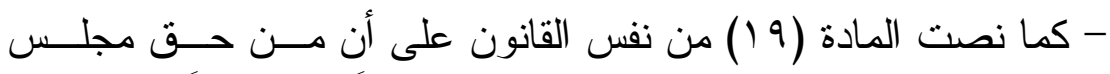

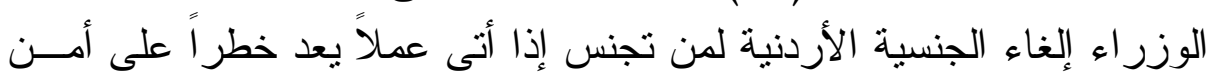
الدولة وسلامتها (0).

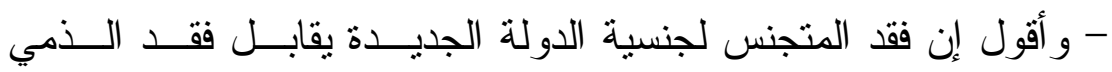

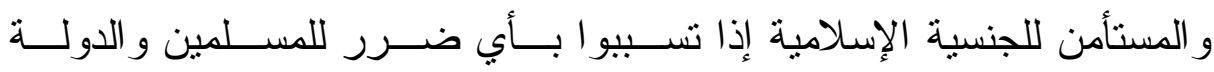

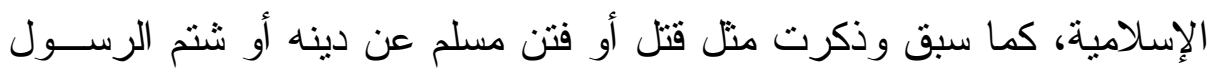

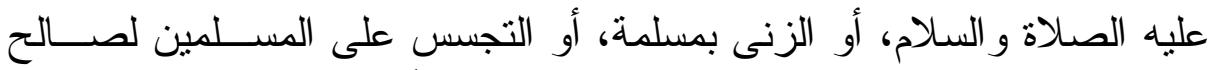
الأعداء فبذلك يفقد الجنسية الإسلامية ويصير محارباً للمسلمين. الزئ.

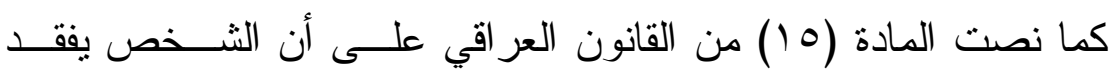

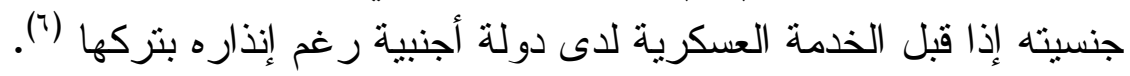

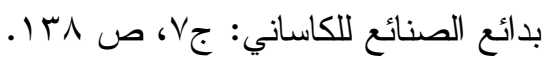

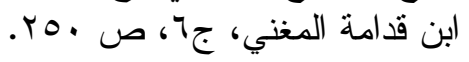

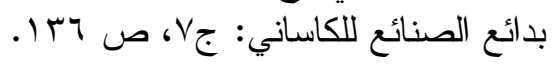

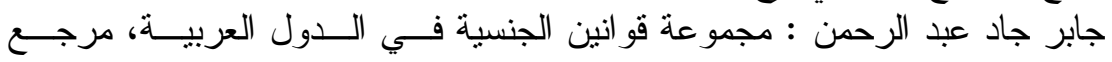

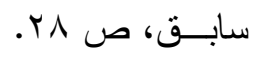

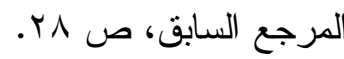

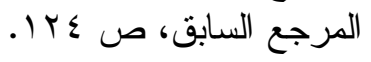


ونصت المادة (T () من القانون السعودي على أن الثخص يفقد جنسيته

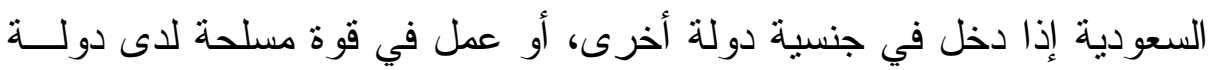

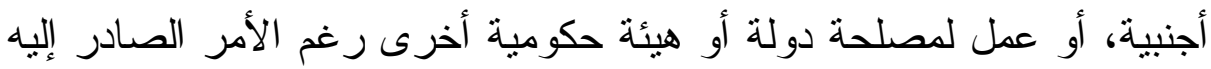

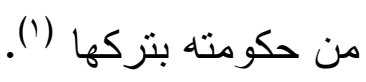

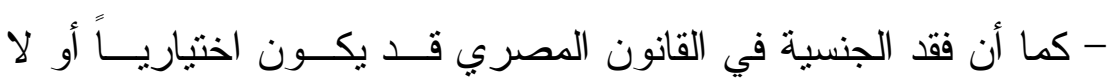

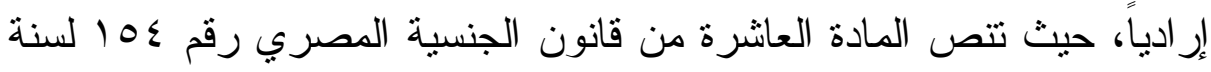

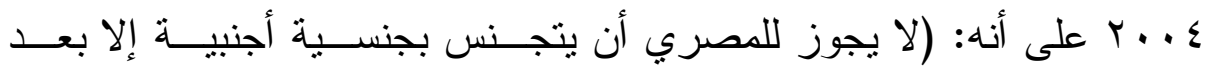

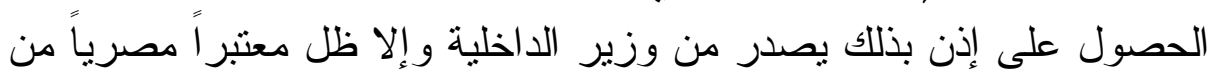

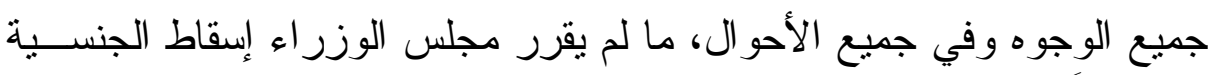

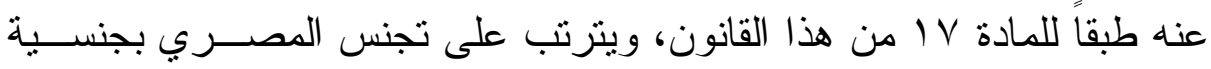
أجنبية منى أذن له في ذلك زو ال الجنسية المصرية عنده).

- كما تتص المادة الخامسة عشر من ذات القانون على أنـــه: (يجـــوز بقرار مسبب من مجلس الوزر اء سحب الجنسية المصرية من كل من اكتشــبها بطريق الغش أو بناء على أقو ال كاذبة خلال السنوات العثر التالية لاكتشــابه

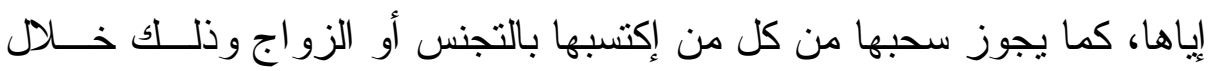
السنوات الخمس التالية لاكتسابه إياها وذلك في أية حالة من الحالات الآنية: 1 - إذا حكم عليه في مصر بعقوبة جنائية أو بعقوبة مقيدة للحرية في جريمة مخلة بالثرف.

r - إذا حكم عليه قضائًا في جريمة من الجر ائم المضرة بأمن الدولــة مــن جهة الخارج أو من جهة الداخل.

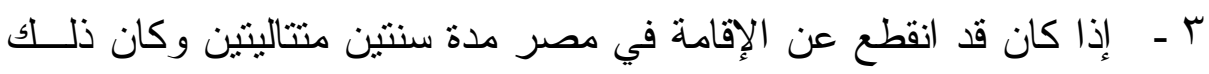
الانقطاع بلا عذر يقبله وزير الداخلية.

- وأرى بعد عرض بعض نصوص قو انين الدول العربيـــة فـــي بيــان

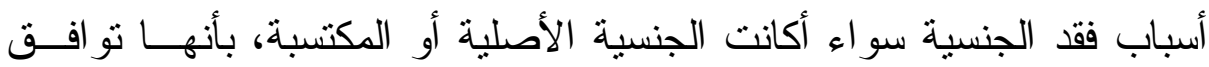

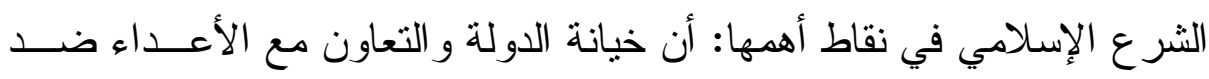

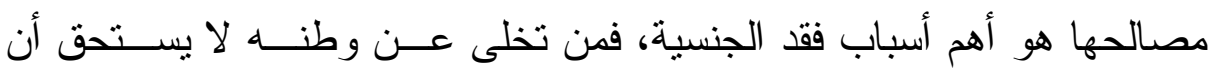

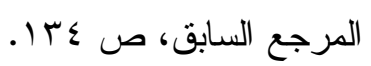


العدد الثاني- الجزء الأول- السنة التاسعة والخمسون-يوليو V|+r =

يحمل جنسيته، وأن يكون أحد مو اطنيه، كذللك من تخلى عن الإسلام بارتهـداده عنه فإنه يفقد الجنسية الإسلامية ويصبح مهدر الدم، ومن تجنس بجنسية دولــة

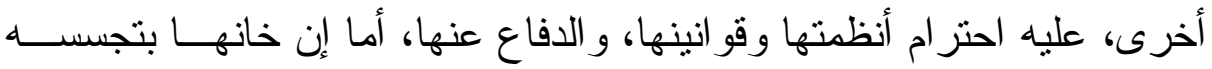
و إعانة عدوها، فإنه بفقد جنسيتها عقوبة على ذلك ويقابله فقد الذمي الجنســية الإسـلامية، إذا أتى عملا يضر إعلى الإسلام و المسلمين. 


\section{الفاتمـــة}

تتاولنا في هذا البحث بياناً لتعريف الجنسية في الفقه الإسلامي و القـانون

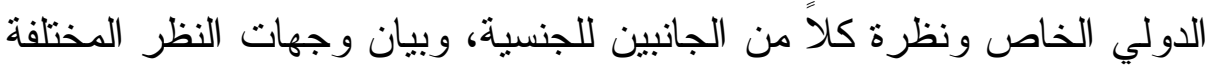

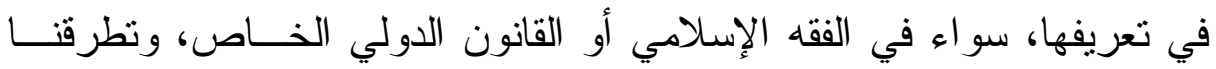

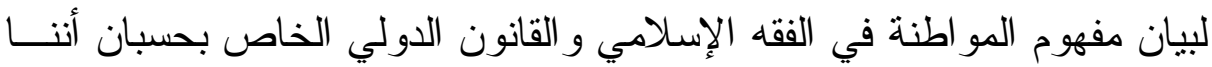
نعيش في عصر يعلي من شأن المواطنة أي الانتماء للوطن و الارتباط به بناء

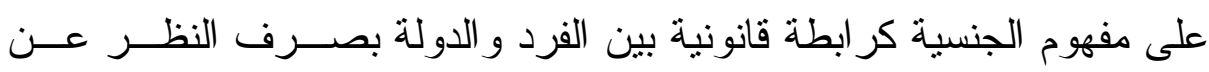

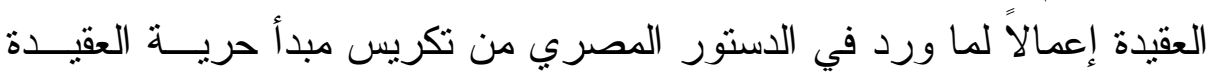

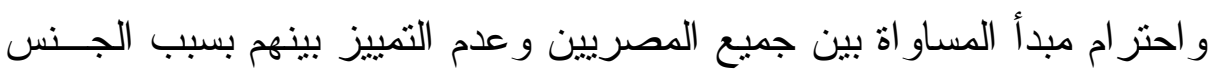

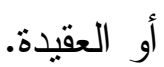

- كذلك أوضحنا اتجاهات الفقهاء في الفقه الإسلامي مـــا بــين إنكــار

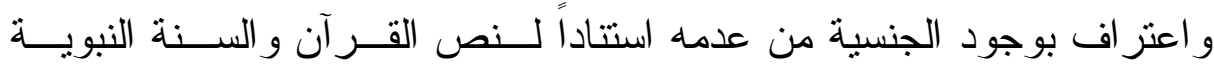
المطهرة، أيضاً نتاولنا حقوق المقيمين في دار الإسلام ومدى اكتسابهم للحقوق

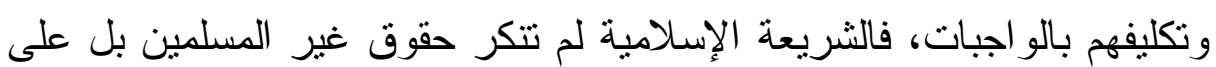

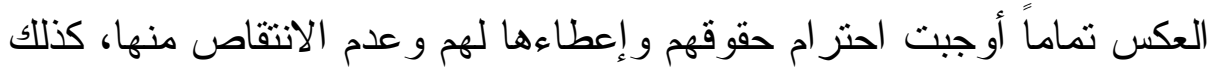

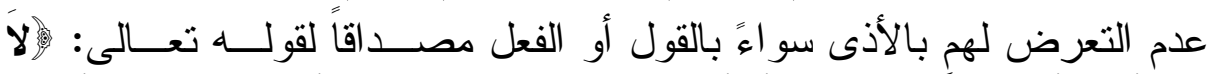

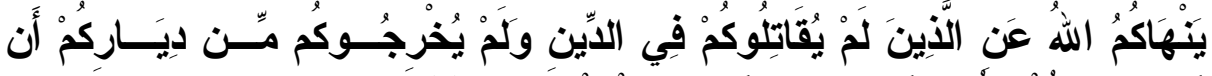

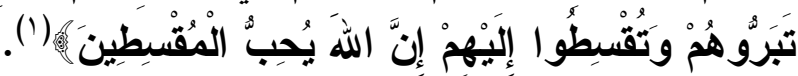

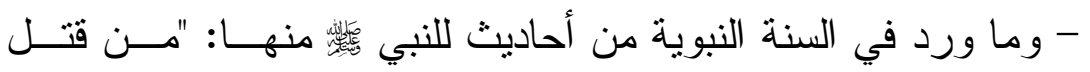
معاهداً لم ير ح ر ائحة الجنة وأن ريحها نوجد من مسيرة أربعين عاماً."

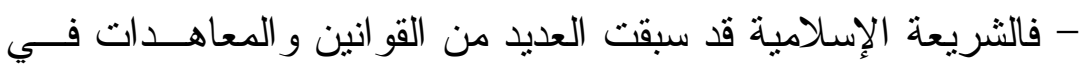

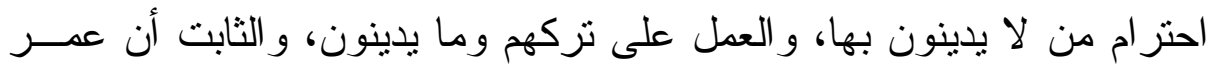

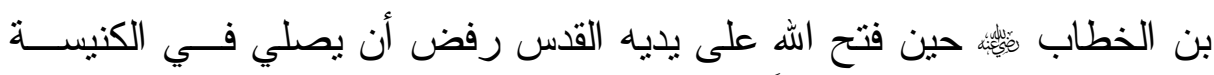

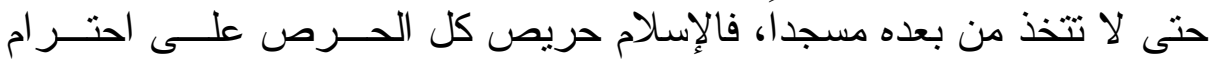

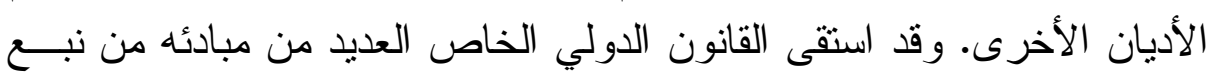

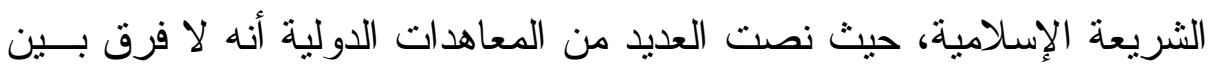

سورة الممتحنة، آية ^. 
إنسان و آخر و لا يجوز التمييز و التفرقة بين البشر وبعضهم على أساس الــدين

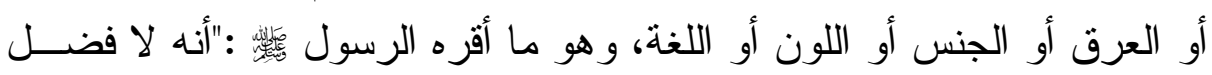

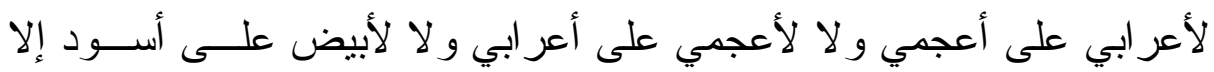

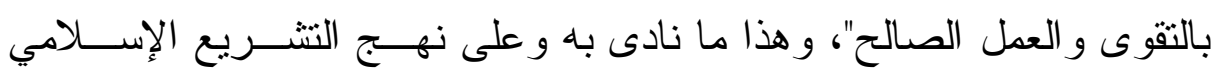
الإعلان العالمي لحقوق الإنسان.

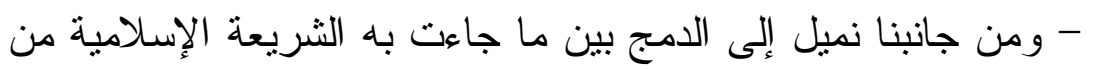

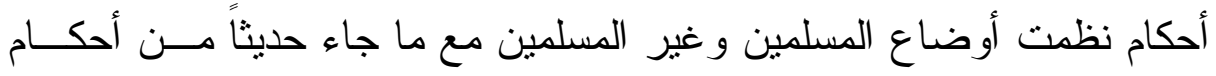

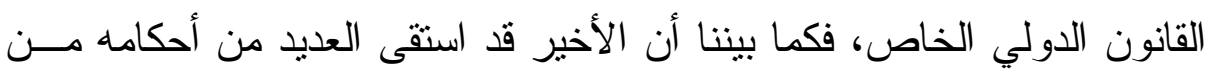

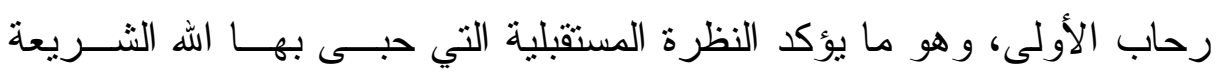

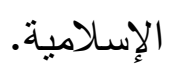

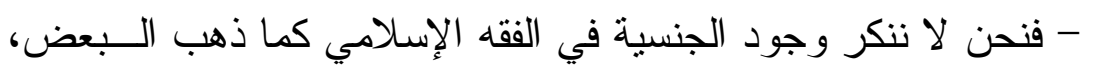

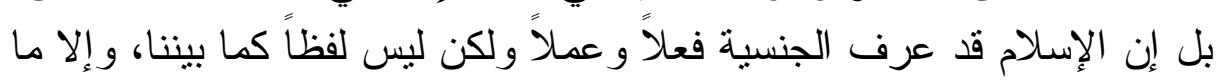

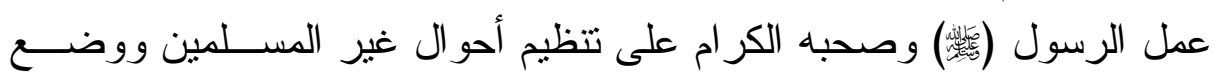
الضو ابط التي تضمن عدم تعرضهم للمتاعب أو المضايقات.

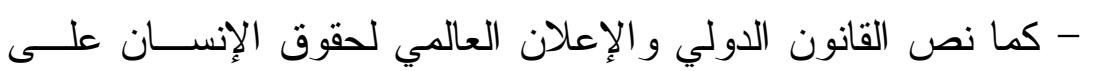

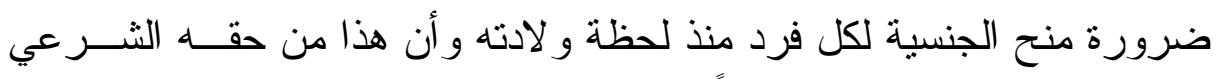
و لا يجوز حرمان أحد منه تعسفاً. 
العدد الثاني- الجزء الأول- السنة التاسعة والخمسون-يوليو Vا.r

\section{التوصيــات}

نظر اً لأهمية موضوع البحث و اتساع البلاد وحاجة المسلمين للاختلاط

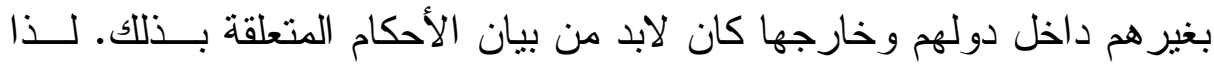
أوصي بما يأتي:

1 - ـ تربية الأبناء منذ الصغر على حب الوطن و الانتماء إليه وهــذا يحتــاج

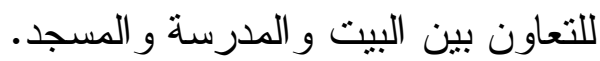

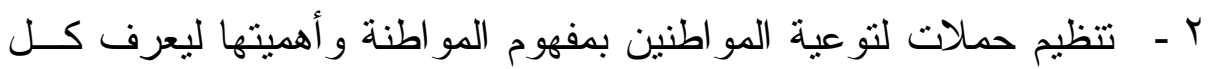
فرد حقوقه وو اجباته.

r - أوصى بعمل أبحاث ودر اسات لها علاقة بموضوع المو اطنة و الجنسـية منل:

أ- أحكام التجنس، وحكم تجنس المسلم بجنسية دولة غيــر إبــلامية

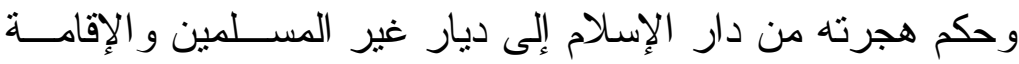

الدائمة فيها.

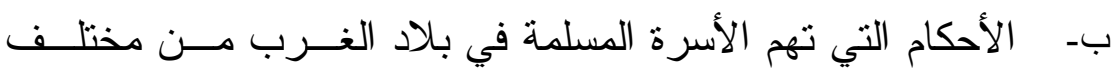

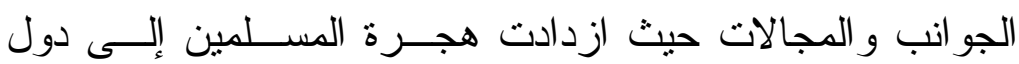

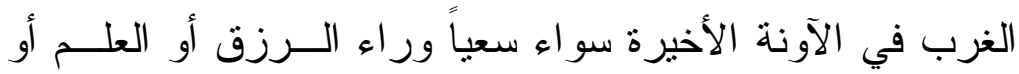

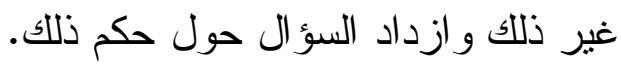


